\title{
Fluid Histories During HP and UHP Metamorphism in Dabie Shan, China: Constraints from Trace Elements, Fluid Inclusions, and Stable Isotopes
}

\author{
Dissertation \\ zur Erlangung des Doktorgrades \\ der Mathematisch-Naturwissenschaftlichen Fakultäten \\ der Georg-August-Universität zu Göttingen
}

\author{
vorgelegt von \\ Yilin Xiao \\ aus Hunan, VR China
}

Göttingen 2000 
D7

Referent:

Prof. Dr. Jochen Hoefs

Korreferent:

Prof. Dr. Gerhard Wörner

Tag der mündlichen Prüfung: 23. 01. 2001 


\section{ACKNOWLEDGEMENTS}

First of all I like to express my sincere thanks to Prof. Dr. Jochen Hoefs, who has been an excellent mentor and gave me full support during my Ph.D work. He has been like a father figure and helped me a lot both on academia and living here during the last 3 and half years. This work could not have been completed in this form without the scientific freedom he allowed me throughout the work. I will always remember that and be grateful for it. I also would like to thank Prof. Dr. Gerhard Wörner for his interest in my work and for taking on the function as a co-advisor.

Special thanks go to Dr. Alfons M. van den Kerkhof. He introduced me into the fluid inclusion methods and has been always patient during our discussions.

Dr. Klaus Simon is thanked for invaluable helps concerning the use of laser ablation ICP-MS and hydrogen isotope analysis, and computer programs.

Dr. J. Fiebig and R. Przybilla are greatly appreciated for their help with the UV-laser ablation method. I kindly acknowledge Dr. A. Kronz for his help during electron microprobe measurements. Dr. G. Hartmann is thanked for his assistance during the XRF analysis.

Prof. Y-F Zheng and Dr. C-S Wei are thanked for the discussion and the good time we spent during field work, which has been carried as a part of the study.

This work has been benefited significantly from discussions with my colleagues and friends in the Geoscience Department. To name a few, Drs. T. Kokfelt, U. Wiechert, T. Zack, B. Schmickler and D. Jacob.

I would also like to thank all my colleagues from the Geochemisches Institut for their contribution to having a pleasant and productive time during my stay.

Last, but never least, I would like to thank my parents, who enabled me the education in China, and my wife Yongmei and my daughter Xiao Xiao, who have accompanied and supported me during my stay in Germany. 
ACKNOWLEDGMENTS 1

TABLE OF CONTENTS 2

Chapter 1. INTRODUCTION 5

Chapter 2. GEOLOGICAL SETTING AND SAMPLING 8

2.1 The Bixiling UHP eclogite 11

2.2 Coesite-bearing eclogite from Shima 13

$\begin{array}{ll}2.3 \text { The Shuanghe UHP metamorphic slab } & 13\end{array}$

2.4 "Cold" eclogite from Lidu 15

2.5 The eclogite from Raobazhai 15

$\begin{array}{ll}2.6 \text { The granulite from Yanzihe } & 16\end{array}$

Chapter 3. ANALYTICAL METHODS 17

$\begin{array}{ll}\text { 3.1 Whole rock chemistry and ICPMS measurements } & 17\end{array}$

3.2 Microprobe analysis 17

3.3 Laser-ICPMS measurements 17

3.4 Microthermometry 17

$\begin{array}{ll}3.5 \text { Oxygen isotope analysis } & 18\end{array}$

$\begin{array}{lr}3.6 \text { Hydrogen isotope analysis } & 18\end{array}$

$3.7^{143} \mathrm{Nd} /{ }^{144} \mathrm{Nd}$ isotope analyses $\quad 19$

Chapter 4. PETROGRAPHY AND MINERAL CHEMISTRY

$\begin{array}{ll}\text { 4.1 Petrography } & 20\end{array}$

$\begin{array}{ll}\text { 4.1.1 Bixiling } & 20\end{array}$

4.1.2 Shima UHP eclogite 23

4.1.3 Jadeite quartzite from Shuanghe 23

4.1.4 "Cold" eclogite from Lidu 24

4.1.5 Eclogite in Raobazhai 25

4.1.6 Granulite in Yanzihe 26

$\begin{array}{ll}\text { 4.2 Mineral Chemistry } & 28\end{array}$

$\begin{array}{ll}\text { 4.2.1 Garnet } & 28\end{array}$

$\begin{array}{ll}\text { 4.2.2 Clinopyroxene } & 28\end{array}$

4.2.3 Amphibole $\quad 29$

4.3 Mineral compositional zonations 30

4.3.1 Garnet in the Lidu eclogite 37

4.3.2 Garnet in the Raobazhai eclogite $\quad 40$ 
4.3.3 Zoned clinopyroxene in Raobazhai 41

4.4 Indicators of peak metamorphic conditions for UHP metamorphism 44

4.5 Clrich amphibole in North Dabie Sha: indicators of Cl-rich solutions 45

\section{Chapter 5. MAJOR AND TRACE ELEMENTS GEOCHEMISTRY}

5.1 Whole-rock geochemical characteristics $\quad 50$

5.1.1 Major elements $\quad 50$

5.1.2 Transition metals 58

$\begin{array}{ll}5.1 .3 \text { Spider diagrams } & 58\end{array}$

5.1.4 Rare earth elements $\quad 61$

5.2 Mineral REE distributions $\quad 62$

5.2.1 The UHP eclogite of Bixiling 62

5.2.2 The coesite-bearing eclogite from Shima 64

5.2.3 The UHP jadeite quartzite from Shuanghe 64

5.2.4 Garnet in the Lidu eclogite 65

5.2.5 The Raobazhai eclogite 66

$\begin{array}{ll}\text { 5.2.6 The granulite from Shuanghe } & 67\end{array}$

$\begin{array}{ll}5.3 \text { Tectonic settings and nature of the protoliths } & 68\end{array}$

Chapter 6. FLUID INCLUSION STUDIES

6.1 Fluid inclusions of the UHP eclogite from Bixiling 72

6.2 Fluid inclusions in the eclogite from Shima 77

6.3 Fluid inclusions in the jadeite quartzite from Shuanghe 78

6.4 Fluid inclusions in the eclogite from Lidu $\quad 80$

6.5 Fluid inclusions in the Raobazhai eclogite 81

6.6 Fluid inclusions in the granulite from Yanzihe 83

Chapter 7. OXYGEN AND HYDROGEN ISOTOPE CHARACTERISTICS OF THE METAMORPHIC ROCKS IN THE DABIE SHAN AREA

$\begin{array}{ll}7.1 \text { Oxygen isotope compositions } & 87\end{array}$

7.1.1 Oxygen isotope data from Bixiling 88

7.1.2 Oxygen isotope compositions of the Shima eclogite 90

7.1.3 Oxygen isotope measurements on the jadeite quartzite from Shuanghe 91

7.1.4 Oxygen isotope zoning of garnets in the Lidu eclogites 91

7.1.5 Oxygen isotope compositions of the Raobazhai eclogite 92

7.1.6 Retrograde fluid/rock interaction indicators for the Yanzihe granulite 94 
7.2 Oxygen isotope thermometry

7.3 Hydrogen isotope analyses of hydroxyl-bearing mineral separates from eclogite and gneiss from the SDT

Chapter 8. METAMORPHIC EVOLUTION AND P-T CONDITIONS

$\begin{array}{ll}\text { 8.1 The Bixiling eclogite } & 101\end{array}$

$\begin{array}{ll}\text { 8.2 The Shima eclogite } & 102\end{array}$

$\begin{array}{ll}\text { 8.3 The Shuanghe jadeite quartzite } & 102\end{array}$

$\begin{array}{ll}\text { 8.4 The Lidu eclogite } & 103\end{array}$

$\begin{array}{ll}\text { 8.5 The Raobazhai eclogite } & 105\end{array}$

$\begin{array}{ll}\text { 8.6 The Yanzihe granulite } & 106\end{array}$

$\begin{array}{ll}\text { 8.7 Summary of P-T conditions } & 107\end{array}$

\section{Chapter 9. DISCUSSION}

9.1 Contrasting P-T paths between the metamorphic rocks from the SDT and NDC

9.2 Fluid compositions during the metamorphic evolution of the investigated rocks

$\begin{array}{ll}\text { from Dabie Shan } & 110\end{array}$

9.3 P-T-t-fluid paths of the metamorphic rocks in the SDT and the NDC 113

9.4 Fluid behavior during metamorphic evolution of the rocks in Dabie Shan 114

9.4.1 Meteoric water-rock interaction prior to metamorphism? 114

9.4.2 Closed fluid system during peak metamorphism 117

9.4.3 Indicators of retrograde fluid/rock interaction 118

9.4.4 Open system conditions in the Lidu eclogite 120

9.5 Origin of nitrogen in metamorphic fluids of Dabie Shan 121

$\begin{array}{ll}9.6 \text { Clbearing amphiboles in the NDC } & 122\end{array}$

Chapter 10. NATURE OF PROTOLITHS AND TECTONIC IMPLICATIONS

$\begin{array}{ll}\text { 10.1 Nature of protoliths } & 125\end{array}$

$\begin{array}{ll}10.2 \text { Tectonic interpretation } & 126\end{array}$

Chapter 11. CONCLUDING REMARKS 129

$\begin{array}{ll}\text { REFERENCES } & 131\end{array}$ 


\section{Chapter 1 INTRODUCTION}

The recognition of coesite and micro-diamond, which were previously thought to form exclusively in the mantle or under cataclysmic conditions, as phases produced during ultrahigh pressure (UHP) metamorphism of undoubted continental crust (e.g., Chopin, 1984; Smith, 1984; Sobolev and Shatsky, 1990; Wang et al., 1989; Okay et al., 1989; Xu et al., 1992; Schertal and Okay, 1994; Caby, 1994), is one of the most significant and far-reaching discoveries in metamorphic petrology. This discovery is revolutionizing our understanding of continental collision zones and mantle dynamics attending subduction of continental lithosphere (Liou et al., 1994; Coleman \& Wang, 1995). The realization that some segments of continental and/or oceanic crust have returned to the surface from depths of $>100 \mathrm{~km}$ challenges the conventional understanding of petrotectonic processes, and raises new questions, such as the uplift mechanism, exhumation rate and cooling history of UHP metamorphic rocks, the extent of rock/fluid interaction and the scale of geochemical recycling of elements between crust and mantle during UHP metamorphism. Localities where ultrahighpressure metamorphic continental rocks have been discovered are the Dora-Maira Massif in western Italy ( Chopin, 1984), the Western Gneiss Region in Norway (Smith, 1984), the Dabie Shan -Sulu area in eastern China( Okay et al., 1989; Wang et al., 1989; Xu et al., 1992), and the Kokchetav Massif in northern Kazakhastan (Sobolev and Shatsky, 1990). These localities can be regarded as "natural laboratories" for UHP metamorphic studies.

It is well known that fluids are powerful agents of metamorphism. From a broader perspective, metamorphic fluid flow has played a significant role in the mineralogical, chemical, and structural evolution of continental crust by redistributing heat, chemical species, and isotope; by controlling the progress of mineral reactions; and by facilitating deformation. Since metamorphism induces important changes in the density and the rhedogy of rocks, the fluid phase also affects the dynamics of an orogeny

Although ultrahigh-pressure metamorphism was previously considered to occur under "dry" conditions, recent studies have demonstrated the presence of several hydrous phases such as phengite, zoisite, epidote and talc in coesite-bearing eclogites, and phologopite and magnesite in some UHP ultramafic rocks as peak mineral assemblages (Okay, 1994; Zhang and Liou, 1994; Liou and Zhang, 1994; Zhang et al., 1995). Experimental studies and thermodynamic calculations suggest that lawsonite and phengite can store $\mathrm{H}_{2} \mathrm{O}$ beyond 200 $\mathrm{km}$ in cold subduction zones (Poli and Schmidt, 1995). Thompson (1992) postulated that substantial quantities of $\mathrm{H}_{2} \mathrm{O}$ could be transported to depths greater than $100 \mathrm{~km}$ by hydrous 
minerals including phengite, clinohumite and epidote/zoisite. The occurrence of these hydrous minerals and carbonate phases indicate that certain amounts of $\mathrm{H}_{2} \mathrm{O}$ and/or $\mathrm{CO}_{2}$ may have been involved during UHP metamorphism and that UHP metamorphism was not "dry", thus the evolution of collision and subduction zones depends not only on temperature and pressure evolution, but also on the fluid budget.

More and more studies have been devoted to determine the chemical and isotopic composition of fluids in a variety of UHP metamorphic localities recently. In the Dora Maira Massif, based on studies of fluid inclusions and stable isotopes, Philippot (1993) has argued that fluid flow was limited during high- and ultrahigh-pressure metamorphism, since the preservation of different fluid compositions, both in time and space, is evidence for local control and the possible origin of the fluids. Detailed fluid inclusion studies of coesite-bearing rocks (Philippot, 1993; Philippot et al., 1995) document a change from low-salinity aqueous fluids containing minor $\mathrm{CO}_{2}$ being present on the burial path to complex saline brines containing an impressive inventory of dissolved elements (e.g., $\mathrm{Mg}, \mathrm{Si}, \mathrm{Al}, \mathrm{Zr}, \mathrm{Ti}, \mathrm{P}$ etc.) occurring at metamorphic peak conditions. Late fluids present during the decompression history were highly saline brines coexisting with $\mathrm{CO}_{2}$. Sharp et al. (1993) have applied both stable isotopic and mineral equilibria approaches to the problem of defining fluid interactions and the role of melting in the Dora Maira Massif. Large scale hydrogen isotopic homogenization contrasts with substantial variations in $\delta 18 \mathrm{O}$ across lithological contacts. Sharp et al. (1993) also have demonstrated through laser-based stable isotopic analyses that minerals within the pyrope-coesite bodies were in high-temperature isotopic equilibrium.

Among the UHP metamorphic terrains found worldwide, the Dabie-Sulu area is the largest. Recent studies have demonstrated that the Dabie -Sulu UHP metamorphic belt is especially interesting for detailed geochemical investigations: i) many hydroxyl-bearing minerals have been reported as UHP phase in eclogites and ultramafic rocks (Okay, 1994; Zhang and Liou, 1994; Liou and Zhang, 1995; Zhang et al., 1995); ii) several oxygen isotope studies on the eclogite and adjacent rocks from the Dabie Shan and eastern China metamorphic terrain (e.g., Baker et al., 1997; Yui et al., 1995, 1997; Zheng et al., 1996, 1998, 1999; Xiao et al., 1997, 1998; Rumble et al., 1998) indicate that minerals from UHP eclogites have $\delta^{18} \mathrm{O}$ values which range from +10 to $-15 \%$ o. This range spans a number of important fluid reservoirs, including those of meteoric water $(<0 \%)$, seawater $(0 \%)$, igneous fluids (> $6 \%$ ), and fluid produced by dehydration during metamorphism (> 10\%o). iii) the world-record highest $\varepsilon \mathrm{Nd}(0)$ values (+170 to +264$)$ even measured for eclogites (Jahn et al., 1996). Furthermore, at least two distinct types of garnet peridotites have been found in his area: type 
A mantle-derived peridotites are considered to be fragments of mantle wedges of the North China plate, whereas type B crustal hosted peridotites are assumed to be portions of maficultramafic complexes of the Yangtze plate emplaced into continental crust prior to subduction (Zhang and Liou, 1998).

As the western part of the Dabie-Sulu UHP metamorphic belt, Dabie Shan is subdivided into the North Dabie Complex (NDC) and South Dabie Terrain (SDT) by a major 200-300 m wide mylonitized contact zone (Hacker and Wang, 1995; Wang et al., 1995). Recent studies have demonstrated many differences between the rocks from NDC and SDT. Geochronologic investigations have revealed significantly different ages for the two terrains: a narrow age range of 210-230 Ma has been determined for the SDT (e. g. Ames et al., 1993; $\mathrm{Li}$ et al., 1993), whereas zircon U-Pb ages for the orthogneiss, which is the major component of the metamorphic rocks in the NDC, range from 138 to 125 Ma (Xue et al., 1997; Hacker et al., 1998). The Sr-Nd isotope study of Jahn et al. (1999a) also has shown that the main rocks of the NDC, characterized by $\mathrm{I}_{\mathrm{Sr}}$ of $0.709-0.710$ and $\varepsilon \mathrm{Nd}(\mathrm{T})$ of -15 to -20 , were derived by partial melting of the lower-intermediate crust; by contrast, most gneisses from the SDT have higher $\varepsilon \mathrm{Nd}(\mathrm{T})$ values of -2 to -10 . Another apparent difference is that, unlike coesite-bearing eclogites are abundant in the SDT, eclogitic rocks have not been undisputably identified in the NDC so far, although UHP metamorphism has been inferred based on some relic minerals (Tsai and Liou, 2000).

These geochemical and petrological differences indicate that metamorphic rocks in the NDC may have a different metamorphic evolution and fluid history from that in the SDT. In order to distinguish the fluid histories of the various rocks from the two metamorphic belts, samples of various rocks have been investigated by major and trace elements, fluid inclusions, and oxygen and hydrogen isotope compositions. The main research goals are:

(1) To characterize the range of fluid compositions generated in rocks that have been subducted to great depths in the earth.

(2) To determine the nature, extent and origin of the pre-, syn- and post-peak metamorphic fluid-rock interactions.

(3) To understand the regionat and submillimeter-scale isotope systematics of the Dabie Shan metamorphic terrain.

(4) To address the extent of fluid communication and flow, and the influence of fluids on the effective metamorphic pressure.

(5) To check if there was a significant crust-mantle interaction during ultrahigh-pressure metamorphism. 


\section{Chapter 2. GEOLOGICAL SETTING AND SAMPLING}

The Dabie-Sulu UHP metamorphic terrain is located in the eastern part of the EWstriking Qinling-Dabie orogenic belt. It represents deep parts of a collision zone between the North China Block and Yangtze Block. Most geologists assume that the Dabie Shan and Sulu region were linked before the Mesozoic, and subsequently the Sulu region was displaced northward approximately $500 \mathrm{~km}$ by the NE-trending left-lateral Tan-Lu fault (Fig. 2.1). The Dabie Shan metamorphic terrain is bounded by four main faults: the Tan-lu strike-slip fault in the east, the Shangcheng-Macheng fault in the west, the Xiaotiao-Mozitan fault in the north and the Xiangfan-Guangji fault in the south; abundant eclogites and other ultrahigh-pressure metamorphic rocks occur in this terrain (Fig. 2.2). Micro-diamond, coesite and coesite pseudomorphs have recently been reported as inclusions in garnet and other minerals in eclogite and adjacent rocks from this area (Okay et al., 1989, 1993; Wang et al., 1989, 1991; Xu et al., 1992; Schertl et al., 1994). It is the third known occurrence of coesite in deep crustal rocks besides the Western Alps in Italy (Chopin, 1984) and the Western Gneiss Region in Norway (Smith, 1984). It is also the second occurrence of diamond of metamorphic origin besides the Kokchetav Massif in northern Kazakhstan (Sobolev et al., 1990)

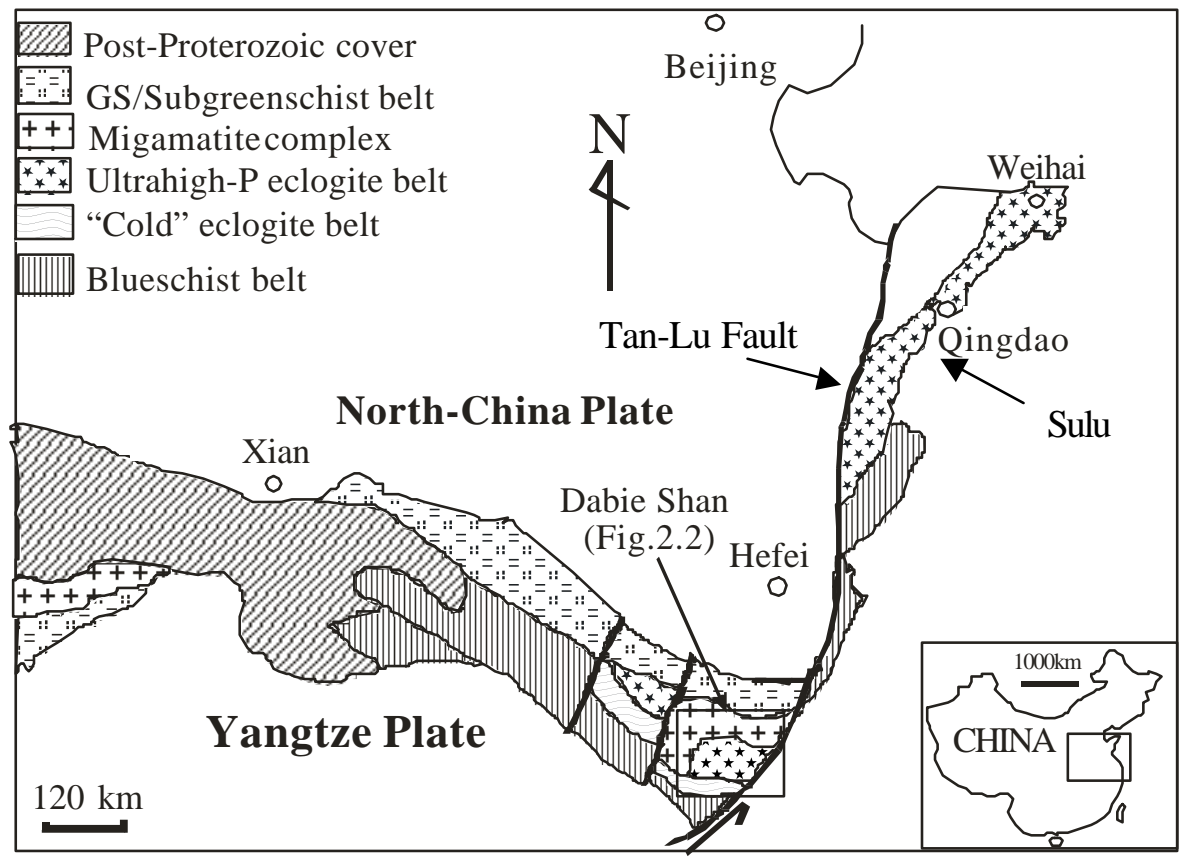

Fig. 2.1 Sketch map of geology and tectonics of the Dabie-Sulu UHP metamorphic belt 
Based on petrotectonic assemblages, the Dabie Shan terrain can be subdivided into four major units (Liou et al., 1995). From north to south, they are: the North Huaiyung Flysch Belt, the North Dabie Complex (NDC), the South Dabie Collision Terrain (SDT), and the Susong Metamorphic Belt (Fig. 2.2).

The NDC is bounded by the Xiaotian-Mozitan Fault in the north and by a ductile shear zone extending from Laibang eastward to the Tianzhushan in the south. The shear zone displays many deformation features including S-C structure, grain rotation, and shear bands of plagioclase and quartz (Wang et al., 1995). The NDC consists mainly of granitoid orthogneiss, migmatite, metasediments and minor amphibolite, granulite, and ultramafic rocks (Okay et al., 1993; Zhang et al., 1996). Granulite facies rocks of various compositions have been reported from numerous localities in the central part of the NDC (Wang 1991; You et al., 1995; Zhai et al., 1994; Zhang et al., 1992; Zhang et al., 1996). Eclogitic rocks have not been undisputably identified (Zhang et al., 1996; Jahn et al., 1999b), but UHP metamorphism has been inferred based on some relic mineralogy (Tsai and Liou, 2000). Sm-Nd isotopic analyses of granitic gneisses give TDM model ages of 1.5-1.8 Ga which provide the upper limit for the ages of their protoliths (Jahn et al., 1999). Biotite and hornblende from the orthogneiss complex yield Ar-Ar ages of 120-130 Ma (Hacker and Wang, 1995). The latest zircon age studies for the orthogneiss (Xue et al., 1997; Hacker et al., 1998) gave ages of 125$138 \mathrm{Ma}$, which has been interpreted either as time of magmatic intrusion of the NDT (Hacker et al., 1998), or as the time of the most significant post-collisional thermal event in Dabie Shan (Jahn et al., 1999a). Because of the intense deformation and thermal recrystallization prior to and during the Cretaceous granitic intrusion, the metamorphic complex has been interpreted as a thermally overprinted subduction complex (Wang and Liou, 1991; Okay and Sengör, 1993; Maruyama et al., 1994), as a Paleozoic Andean-type magmatic arc complex (Zhai et al., 1994; Wang et al., 1996), as a metamorphic ophiolite melange complex (Xu, 1989; Xu et al., 1992, 1994), as a Cretaceous extensional-magmatic complex (Hacker et al., 1995, 1998), as part of the North China craton in the hanging wall of the subduction zone (Liou at al., 1996; Zhang et al., 1996), or as an extruded subduction assemblage, which involved a micro-continental of transition crust and the Yangtze basement, onto the North China craton following an Alpine-model (Hacker et al., 1996).

The SDT occupies the southern part of the Dabie Shan. It is bounded by a major mylonitzied contact with the NDC to the north and by Taihu-Mamiao Fault in the south, and is characterized by the occurrence of ultrahigh-pressure metamorphic rocks This belt consists mainly of quartzofeldspathic gneisses. Eclogites, marbles, ultramafics, jadeite quartzite occur 


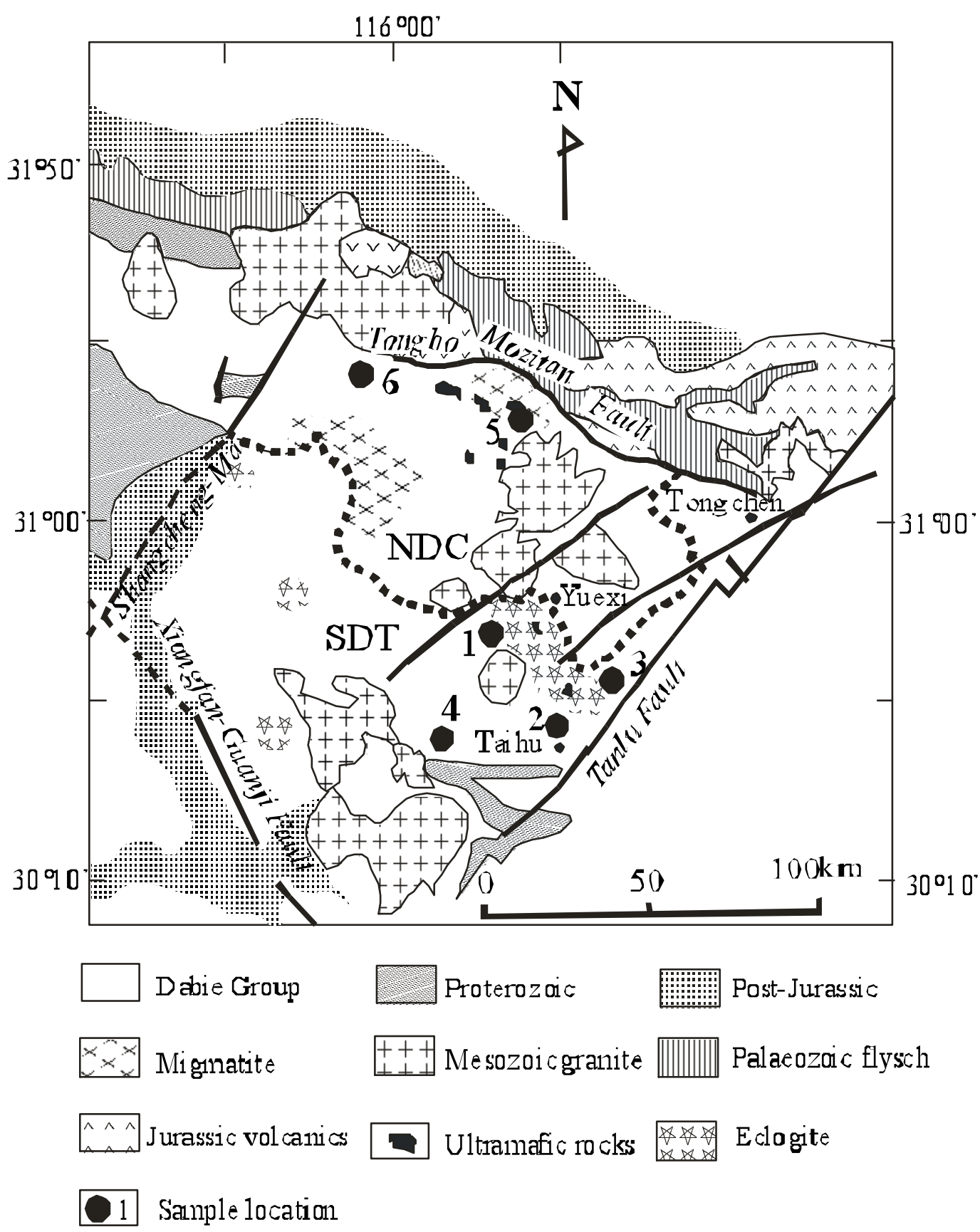

Fig. 2.2. Geological sketch map of the Dabie Shan region. The dotted line in the middle is the boundary between the North Dabie compolex (NDC) and the South Dabie Terrain (SDT) (after Wang et al., 1992). Sample locations: 1 Bixiling, 2 Shima, 3 Shuanghe, 4 Lidu, 5 Raobazhai, 6 Yanzihe.

as lenses, blocks and/or layers in the gneisses. Coesite and diamond have been recognized as inclusions in minerals from eclogite (Okay et al., 1989,; Wnag et al., 1989; Xu et al., 1992; Okay, 1993). Coesite pseudomorph and other relic high $\mathrm{P} / \mathrm{T}$ metamorphic assemblages indicate that some gneisses also have undergone UHP metamorphism (Wang and Liou, 1991; 
Schertl and Okay, 1994; Cong et al., 1995). Based on Sm-Nd analyses of eclogitic minerals, it has been proposed that UHP metamorphism and collisional events took place at 210-230 Ma (e. g., Li et al., 1993; Chavagnac and Jahn, 1996). This hypothesis has been supported by U $\mathrm{Pb}$ zircon analyses (Ames et al., 1993, 1996; Maruyama et al., 1994; Rowley et al., 1997; Hacker et al., 1998) and is basically in agreement with the conclusion deduced from paleomagnetic data (Lin et al, 1985; Yang et al., 1991, 1992). However, other opinions also exist. These include: (a) a Devonian collision based on a regional geochemical investigation of fine-grained clastic sediments in the Qinling orogenic belt (Gao et al., 1995), (b) an Archean or a Proterozoic UHP metamorphic events based on UPb zircon dating (Liu et al., 1995), and (c) a prolonged UHP metamorphism from 480 to c. 200 Ma based on Sm-Nd, U$\mathrm{Pb}$ and $\mathrm{Ar}-\mathrm{Ar}$ age results of Dabie eclogites (You et al., 1995). On the other hand, Okay and Sengör (1993) subdivided this belt into two terrains: a northern "hot" eclogite terrain characterized by coesite-bearing eclogite and marble-eclogite association, and a southern "cold" eclogite terrain with sodic amphibole-bearing eclogites. Geochronological studies indicate that both types of eclogites formed during 210-230 Ma ( $\mathrm{Li}$ et al., 1989, 1993; Ames et al., 1993; Franz et al., 2000).

For the purpose of comparing the fluid histories of the NDC and the SDT, six representative localities were selected for the present study (Fig. 2.2). More than 60 samples were collected. Investigated samples from the SDT included coesite and diamond-bearing eclogite from Bixiling, coesite-bearing eclogite from Shima, UHP jadeite quartzite and eclogite from Shunaghe, and "cold" eclogite from Lidu. Samples from the NDC included eclogite (or garnet pyroxenite) from Raobazhai and granulite from Yanzihe. Locations are shown in Fig. 2.2 and main petrogical characteristics are summarized in Table 4.1.

\subsection{The Bixiling UHP eclogite (sample DB02, DB05, DB07 and DB10)}

The Bixiling eclogite associated with the meta-ultramafic complex is one of the largest coesite-bearing eclogitic bodies in Dabie Shan and has been described in detail by Zhang et al. (1995), Liou and Zhang (1995), Chavagnac and Jahn (1996). The complex occurs as a tectonic block and outcrops in an area of about $1.5 \mathrm{~km}^{2}$ within foliated quartzofeldspathic gneiss, and mainly consists of "fresh" eclogite, kyanite-rich eclogite, retrograded eclogite and elongated lenses of meta-ultramafic rock. Retrograded eclogite mainly developed at the margins of the complex, whereas the majority of the "fresh" eclogites occurs in the central part of the complex. Field relationships and petrological studies suggest a cumulate origin of 
the complex. The boundary between the complex and country rock shows tectonic contact relations. However, the contacts between different types of eclogites, as well as the metaultramafic rocks, are gradual (Zhang et al. 1995), indicating that both eclogites and ultramafic rocks underwent the same UHP metamorphism. Sm-Nd isotopic analysis on garnet and omphacite from eclogite and garnet peridotite give tightly grouped isochron ages of 210218 Ma (Chavagnac and Jahn 1996). Their results concurs with the ages of 209 Ma from eclogite and 217 Ma from surrounding gneiss (Xiao et al. 1995).

Sampling was carried out along a north-south road section across the Bixiling eclogitic rock body. More than 20 samples were collected and four of them were selected for detailed studies (Fig. 2.3). Two samples collected from the central part of the complex, eclogite with coarse-grained kyanite (sample DB07) and "fresh" eclogite without kyanite (sample DB05), do not show retrograde signs. Strongly retrograded eclogite was collected at the margin of the complex (sample DB02). Sample DB10 is a garnetperidotite from an elongated lens of garnetbearing meta-ultramafic rock of about 20 x 300 meters.

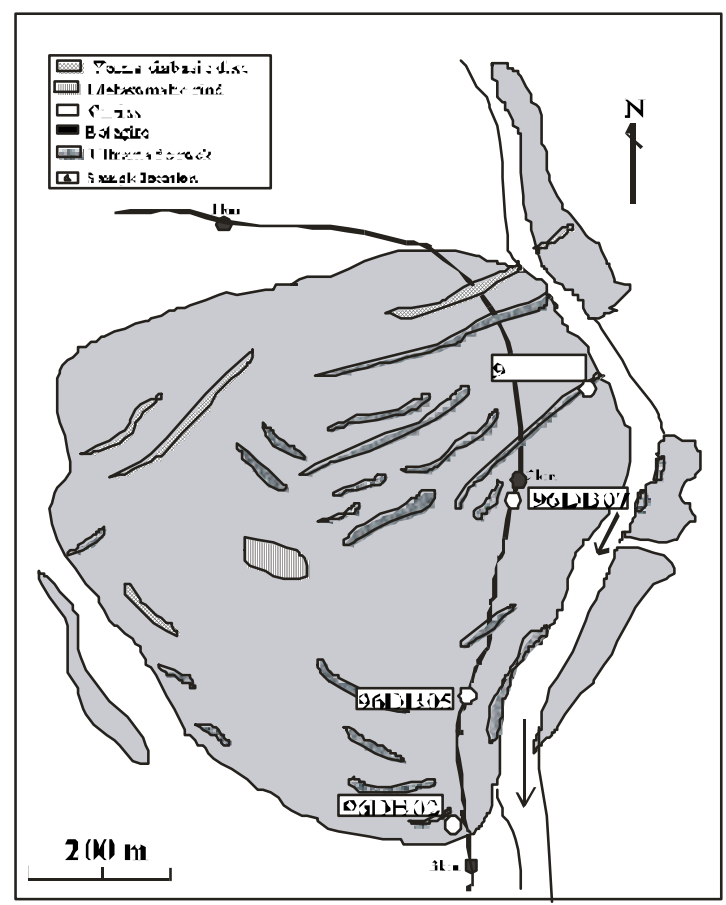

Fig 2.3. Geological map of the Bixiling eclogite

\subsection{The coesite -bearing eclogite from Shima (sample DB61, DB63)}

Coesite-bearing eclogitic rocks are well developed in the Shima region and occur as aggregate layers or boundins in garnet-bearing biotite gneisses and boundins in impure marbles. Foliation of country rocks goes around the eclogite blocks, which represent about 
$2 \%$ of the total rock volume, but locally may be up to $10 \%$. Field occurrences of these eclogites have been described in detail by Wang et al. (1990). Inclusions of coesite relics and coesite pseudomorphs were first identified by Wang et al. (1989) in garnet and omphacite of these eclogites and coesite relics also occur in zircon of interlayered gneissic rocks (Sobolev et al., 1994).

A lot of coesite-bearing eclogites ranging from $\mathrm{cm}$ to more than one meter in size, occurring at a stream bottom (Fig. 2.4). These blocks are strongly foliated and stand out because of their resistance to erosion; one of the collected samples (DB63) exhibits compositional bands of pink, garnetrich layers interbedded with green omphacite-rich layers. Sample DB61 is an eclogite in impure marble.

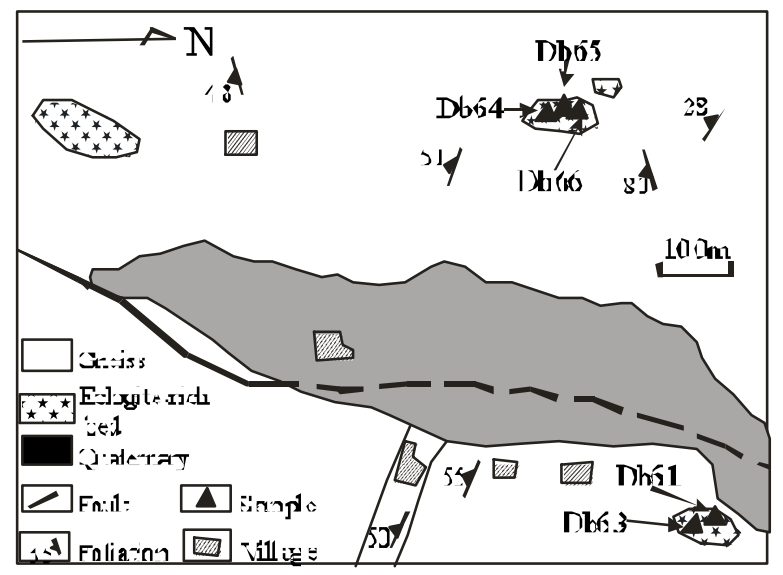

Fig. 2.4 Simplified geological map of the Shima area (modified after Wang 1990)

\subsection{The Shuang he UHP metamorphic slab (sample DB29, DB31, DB32)}

The ultrahigh pressure metamorphic rocks at Shuanghe occur as a thrust slab which was offset by a dextral strike-slip fault (Fig. 2.5). Various types of ultrahigh pressure or high pressure metamorphic rocks occur in this area:

( a ) Marble with or without eclogite boundins;

( b ) Layered eclogites intercalated with paragneiss;

(c) Massive eclogite ranging from several meters to about one hundred meters in width;

( d ) Coesite-bearing jadeite quartzite;

In this area, various eclogites have been studied in detail. Coesite inclusions have been found in garnets and other minerals within eclogites and jadeite quartzite (Cong et al., 1995; Liou et al., 1997). The other rocks were also considered to be subjected to ultrahigh pressure metamorphism (Cong et al., 1995). Stable isotope study have shown a large variation in $\delta^{18} \mathrm{O}$ values of garnet and omphacite $(-2.6$ to $+7.0 \%$ ), but a small range in phengite $\delta \mathrm{D}$ value 
(Zheng et al., 1998). Sm-Nd mineral dating of eclogites gave an age of $226 \pm 3 \mathrm{Ma}$ for the UHP metamorphism in this area ( $\mathrm{Li}$ et al., 2000). However, the less studies have been contributed to the jadeite quartzite. Thus in the Shuanghe UHP slab we focus on the investigation of jadeite quartzite.

The Shuanghe jadeite quartzite lens occurs as a medium-grained, grayish colored band in marble with $8-10 \mathrm{~m}$ thickness (Fig. 2.5). It has an assemblage of garnet + jadeite + quartz (coesite) + rutile. Jadeites are successively rimmed by coronas of fibrous oligoclase (inner rim) and albite (outer rim ) + minor Ca-clinoproxene. Garnets are replaced by amphibole , albite and aegirine rimward. Inclusions of quartz pseudomorphs after coesites can be found both in garnet and jadeite. The eclogite boundin within marble has a relatively simple mineral assemblage: Garnet + omphacite + coesite + quartz + rutile \pm carbnate. Layered eclogites intercalated with paragneiss have a mineral assemblage of garnet + omphacite + quartz (coesite) + phengite + rutile + kyanite; eclogitic minerals are slightly altered: omphacite is rimmed by a thin layer of very fine-grained symplectite, a margin of phengite is replaced by biotite.

Collected samples from this area include eclogite boundins in marble (DB29), jadeite quartzite (DB31), and layered eclogite with paragneiss (DB32).

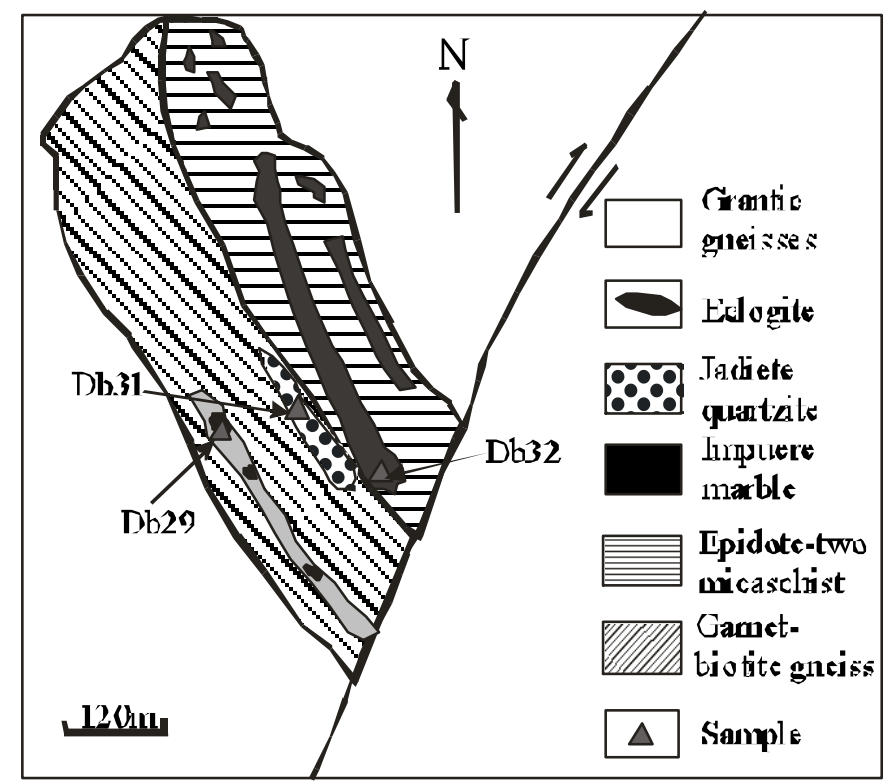

Fig. 2.5. Geologic map of the Shuanghe UHP slab (modified after Cong et al., 1995)

\section{4 “Cold” eclogite from Lidu (sample DB44, 45, 48, 50)}

Okay (1993) and Carswell et al. (1993) suggested that eclogites in Huangzhen are different from eclogites in other localities, and postulated that there are two contrasting 
eclogite terrains in the Dabie Shan: " hot eclogite " and "cold eclogite" terrains. Zhai et al. (1995) pointed out that the country rocks of hot eclogites are generally garnet-bearing granitic orthogneiss, paragneiss, marble, or ultramafics, whereas the country rocks of cold eclogites are magnetite-bearing meta-sandstone. The most important evidence for such a division is that so far no coesite or micro-diamond inclusions were found in these "cold" eclogites. However, Baker et al. (1994) have argued that the difference between " hot eclogite " and "cold eclogite" may be due to the different extent of fluid/rock interaction as evidence from $\delta^{18} \mathrm{O}$ values; the "cold" eclogite terrain may have been subjected to more intensive retrograde metamorphism, thus coesite inclusions are not preserved.

The biggest and most representative cold eclogite lens is exposed on the south side of Lidu village near Huangzhen. In Castelli et al.'s (1998) paper the lens was named as Zhu-JiaChong eclogite. The eclogite outcrops in an area about $500 \mathrm{~m}$ in length and $150 \mathrm{~m}$ in width (Fig. 2.6). The host rock is a two mica-epidote-garnet-plagiclase gneiss. Megascopic isoclinal and open folds are found in the gneiss, showing subhorizontal northwest-southeast-trending axes (Castelli et al., 1998). The eclogite exhibits both weak foliation consistent with the trend of the host gneiss foliation steeply plunging towards south-southwest.

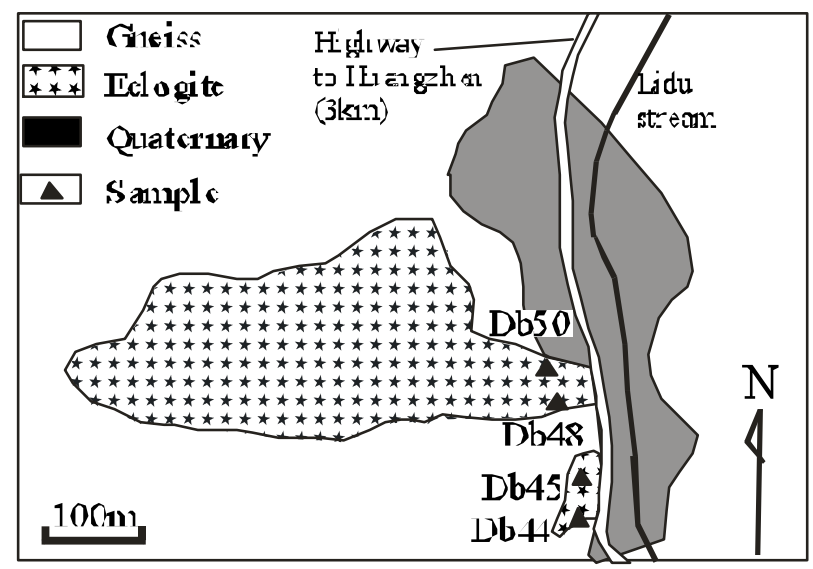

Fig. 2.6. Schematic map of the Lidu eclogite.

\subsection{The eclogite from Raobazhai, NDC}

The Raobazhai meta-ultramafic complex is located at the southern Foziling Reservoir near Huoshan in the NDC (Fig. 2.7), with an outcrop area of about $3 \mathrm{~km}$ in length and 0.2-0.9 $\mathrm{km}$ in width. The complex, which was emplaced in solid state into gneisses of the Dabie Group (Yang et al., 1983), consists mainly of Cr-spinel harzburgite, dunite and garnet pyroxenite. The country rocks near the contact zone are strongly mylonitizated. Foliations are well developed along the margin of the complex. 
The studied samples were collected from a garnet pyroxenite xenolith that occurs in the intensely deformed Raobazhai ultramafic complex and is arranged in a linear fashion parallel to the trend of the mylonite zone (Xiao et al., 2001). In the same complex an age of $244 \pm 11$ Ma has been derived based on garnet-clinopyroxene-whole rock Sm-Nd isotope data (Table 2 and Fig. 5A of $\mathrm{Li}$ et al., 1993). The garnet pyroxenite was characterized as a type-I eclogite by $\mathrm{Li}$ et al. (1993), although omphacite as a typical eclogite facies mineral has not been observed. Xu et al. (1994) interpreted the Raobazhai complex as a part of an ophiolitic melange complex, but a more detailed study suggests it may be a mantle-derived block (Zhang et al., 1995).

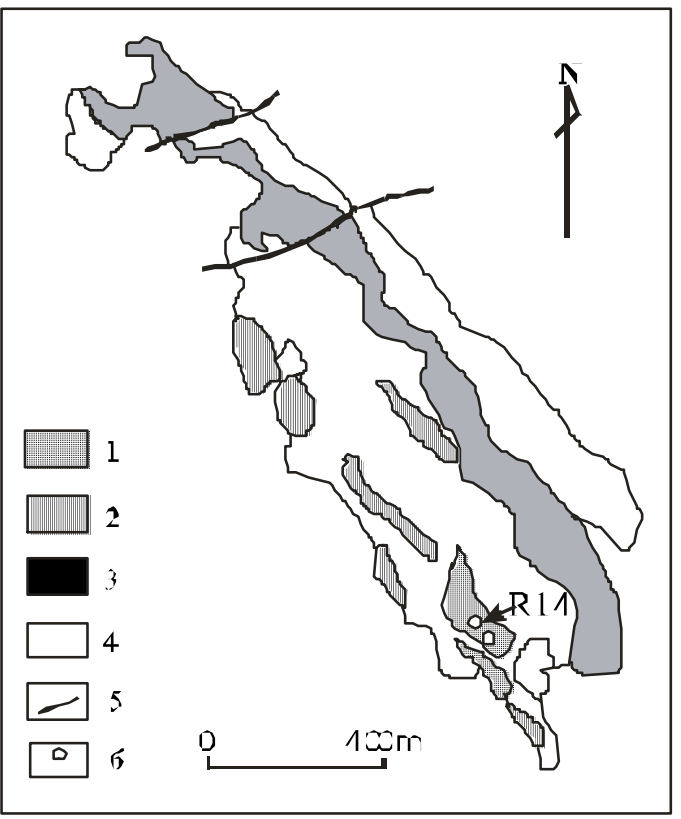

Fig. 2.7 Geological map of the Raobazhai complex (modified after Yang, 1983). 1 eclogite; 2 hornblende-peridotite; 3 mylonitization peridotite; 4 harzburgite, lherzolite and dunite; 5 fault; 6 sample location

\subsection{The granulite from Yanzihe}

Granulite-facies rocks are widespread in the Dabie Shan, occuring in the Yanzihe, Anhui Province, and in the Luotian and Macheng, Hubei Province of China, and can be divided into at least five types according to their composition (Zhang et al., 1996). They are surrounded sequentially by gneisses with upper- and/or lower- amphibolite-facies metamorphism

The felsic granulite from the Yanzihe region is hosted by gneiss with upper amphibolite-facies metamorphism and mainly consists of garnet, orthopyroxene, amphibole, quartz and plagioclase. Peak metamorphic conditions of $>800{ }^{\circ} \mathrm{C}$ at $12 \mathrm{kbar}$ were estimated by Zhang et al. (1996). 


\section{Chapter 3. ANALYTICAL METHODS}

\subsection{Whole rock chemistry and laser ICPMS measurements}

Whole rock chemistry of the samples was determined by X-ray fluorescence (XRF) and ICPMS techniques. Bulk-rock analyses by XRF involved glass disks. Analyses were performed with a Philips PW 1480 automated sequential spectrometer (see Hartmann, 1994). Samples ( 100 mg) for ICP-MS were digested with $1 \mathrm{ml}$ of $\mathrm{HF}, 1 \mathrm{ml}$ of $\mathrm{HClO}_{4}$ and $4 \mathrm{ml}$ of $\mathrm{HNO}_{3}$ at $200^{\circ} \mathrm{C}$ for about $15-24$ hours in Teflon beakers before evaporation to dryness and dissolution of the residue. Measurements were performed using a VG PlasmaQuad2 + ICPMS.

\subsection{Microprobe analysis}

Chemical compositions of mineral phases were determined by electron-microprobe analysis using a JXA-8900RL Jeol Superprobe at the Geochemistry Institute Göttingen equipped with WD/ED combined micro-analyzer. The analysis was performed at $15.0 \mathrm{kV}$ accelerating voltage, $12 \mathrm{nA}$ beam current and $5 \mu$ probe diameter. Standards included silicates and pure oxides. Measurements were made on well polished sections with thickness $<2 \mathrm{~mm}$. Raw data were calculated by the CITZAF method of Armstrong (1991).

\subsection{Laser-ICPMS measurements}

Single mineral trace elements were determined using a laser ablation ICP-MS. The ablated particles are transported by an argon gas stream into the VG PlasmaQuad 2 + ICPMS. The typical parameters of analysis and the experimental procedure have been described by Simon et al. (1997) in detail.

\subsection{Microthermometry}

Fluid inclusions were investigated by using a Linkam heating/freezing stage, provided with a video system for ease of observation at the Geological Institute of the University Göttingen. Measurements were made on doubly polished unmounted $\sim 200 \mu \mathrm{m}$ thick sections. The stage was calibrated by a set of synthetic fluid inclusion standards. For temperatures below $-56.6{ }^{\circ} \mathrm{C}$ accuracy is better than $0.5^{\circ} \mathrm{C}$. Temperatures around $0{ }^{\circ} \mathrm{C}$ have accuracy of 0.2 
${ }^{\circ} \mathrm{C}$, whereas for temperatures between 200 and $600{ }^{\circ} \mathrm{C}$ accuracy is better than $5{ }^{\circ} \mathrm{C}$. Measurements were made of the eutectic temperature $\left(T_{e}\right)$, final melting temperature $\left(T_{m}\right.$ ice and $T_{m}$ co2) and homogenization temperature $\left(T_{h}\right)$. Heating rates of $1{ }^{\circ} \mathrm{C}$ per minute were used for $\mathrm{T}_{\mathrm{m} \text { ice, }} \mathrm{T}_{\mathrm{m} \mathrm{co} 2}$ and $\mathrm{T}_{\mathrm{mCO} 2}$, and $5{ }^{\circ} \mathrm{C}$ per minute for $\mathrm{T}_{\mathrm{h}}$ of aqueous inclusions.

\subsection{Oxygen isotope analysis}

All samples investigated for oxygen isotope analysis have been prepared as well polished thick sections (ca. $15 \times 10 \times 2 \mathrm{~mm}$ ). The sections were cleaned with distilled water using an supersonic device and then vacuum dried overnight at $300{ }^{\circ} \mathrm{C}$.

In-situ oxygen isotope analysis was done by ArF-laser fluorination. This technique has been described by Fiebig et el. (1999). For analysis of the present samples some major changes have been carried out: The MAT 251 has been replaced by a Finnigan Delta Plus mass spectrometer, which allows oxygen isotope detection on masses 32, 33 and 34. Both standard and sample oxygen are introduced via a continuous flow inlet system into the ion source using He as a carrier gas, as described by Merrit and Hayes (1994). In this way lateral resolution has been improved down to $250 \mu \mathrm{m}$. A detailed description of this new technique is given by Fiebig (1999) and Wiechert et al. (2001). In contrast $\mathrm{t}$ the oxygen isotope analytical methods described by Sharp (1990) and Elsenheimer and Valley (1992), the UV laser-based micro-analytical technique for in situ oxygen isotope analysis of silicate does not cause any fractionation during laser ablation (Wiechert and Hoefs, 1995).

As guard against contamination, an olivine standard $(5.1 \pm 0.2 \%$ ) has been run at the beginning and at the end of each measurement day. All standard analyses gave the reference value within errors so that raw data did not have to be corrected. Due to explosive ablation resolution of the quartz samples was $500 \mu \mathrm{m}$. For all other minerals resolution varied between 250 and $350 \mu \mathrm{m}$, mostly depending on focal properties. The routine analytical error for oxygen analysis based on replicate analysis and standards is better than $0.2 \%$. The isotopic results are reported in the conventional $\delta$ notation in per mil relative to SMOW. Electron microprobe analysis was performed both prior and after laser-probe measurements in order to ensure oxygen isotope analysis of representative and fully documented mineral compositions. 


\subsection{Hydrogen isotope analysis}

Hydrogen isotope analyses were performed by vacuum fusion with inductive heating to $1300{ }^{\circ} \mathrm{C}$, conversion of liberated $\mathrm{H}_{2} \mathrm{O}$ to $\mathrm{H}_{2}$ over uranium at $800 \mathrm{C}$, and adsorption of the $\mathrm{H}_{2}$ on activated charcoal. Hydrogen isotope ratios are normalized to the V-SMOW-SLAP scale (c.f. O'Neil 1986), and precision is about $\pm 2 \%$. The measured $\delta \mathrm{D}$ of NBS-30 was $62 \%$.

\section{$3.7{ }^{143} \mathrm{Nd} /{ }^{144} \mathrm{Nd}$ isotope analysis}

Two samples from the NDC were investigated for their ${ }^{143} \mathrm{Nd} /{ }^{144} \mathrm{Nd}$ isotope ratios. Element separation was performed in two steps: a cation exchange column with $\mathrm{HCl}$ chemistry, preceded a separation of $\mathrm{Nd}$ on Teflon columns coated with HDPE. The analyses were performed on a Finnigan MAT 262 at the IGDL in Göttingen operated in static mode. The total analytical error on the $\mathrm{Nd}$ isotope abundances is less than $1 \%$. The external reproducibility on La Jolla standard solution was $0.511839 \pm 0.000007(2 \sigma, \mathrm{n}=80)$. The $\mathrm{Nd}$ isotope ratio was corrected for mass fractionation to ${ }^{146} \mathrm{Nd} /{ }^{144} \mathrm{Nd}=0.7219$ and adjusted to recommended values for La Jolla standard (0.511858). Blanks range from 100 to $200 \mathrm{pg}$, and thus no blank correction was necessary. 


\section{Chapter 4. PETROGRAPHY AND MINERAL CHEMISTRY}

\subsection{Petrography}

More than 60 samples representing various rock types in the six localities were examined petrographically. Out of these characteristic samples which contain large garnet crystals for micro-chemical analysis were selected for further studies. The modes of samples that have been studied in detail are listed in Table 4.1.

\subsubsection{Bixiling}

The most common eclogite in Bixiling contains garnet, omphacite, quartz with varying proportions of phengite, kyanite, amphibole and zoisite as major components and rutile (sometimes very abundant), apatite and zircon as accessory minerals. Coesite and coesite pseudomorphs in garnet and omphacite have also been found in some thin sections (Fig. 4.1).

Garnet in the eclogite mainly occurs as idioblastic crystals with kelyphitic rims of amphibole and/or prophyroblasts with inclusions of rutile, omphacite, phengite and quartz and/or coesite. Although garnets from eclogite display a relatively large compositional range resulting from variations of bulk composition and mineral assemblage of their host rock (Zhang et al., 1995), there is no significant compositional zoning from the core to the rim of garnet.

Omphacites can be divided into two generations: fine-grained omphacite which is preserved only as inclusions in garnet and kyanite, and coarse-grained matrix omphacite which coexists with garnet. Importantly, omphacite inclusions have higher $\mathrm{Jd}$ component than matrix omphacites. As the Jd content of a pyroxene has great implications in terms of P-T conditions, such a change may indicate that these omphacite inclusions in garnet form under higher pressure conditions. The fact that some omphacite inclusions contain K-contents up to $1 \mathrm{wt} \%$ supports this assumption (see below for details).

Kyanite occurs as a primary phase in eclogite. Some kyanite grains with abundant inclusions of omphacite and quartz are up to $3 \mathrm{~mm}$ in size.

Zoisite can be found in some eclogites. Coesite relics and coesite pseudomorphs in zoisite suggest that zoisite is a stable UHP phase (Zhang et al., 1995).

Phengites can be grouped in two categories: phengite inclusions in garnet and omphacite, and coarse-grained phengite which coexists with garnet. Coarse-grained phengite appears texturally to be a stable phase in eclogite coexisting with the other eclogite-facies minerals. 
Table 4.1. Estimated modes for major minerals of the investigated samples. [Mineral abbreviations after Kretz (1993) except for: Am amphibole, Coe coesite, Phen phengite], $\operatorname{Tr}$ trace.

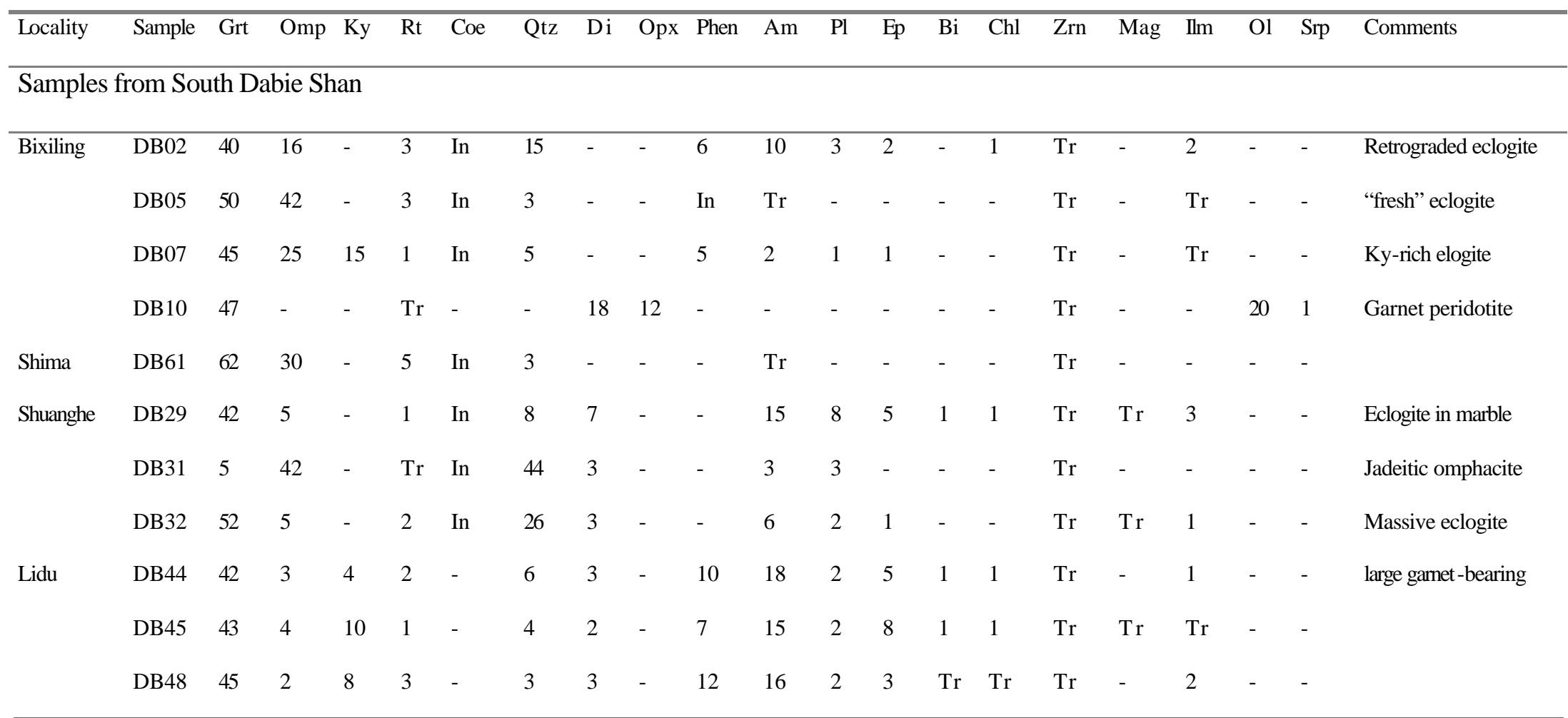

Samples from North Dabie Shan

R14

$38 \quad 12 \quad-\quad 5$

$15 \quad 1$

15

$10-2$

$\operatorname{Tr}$

Opx overgrow

around cpx 
Amphibole, if present, can be also divided into two generations. One generation of amphibole (barroisite) is intergrown with sodium plagioclase and micro-grained clinopyroxene in symplectite after omphacite. The other is coarse-grained hornblende that exists as kelyphitic rims of garnet grains.

After a general petrographic inspection, including thirty-three thin sections of eclogites and six of ultramafic rocks, four samples, which represent the major rock types of Bixiling, were selected for detailed analysis.
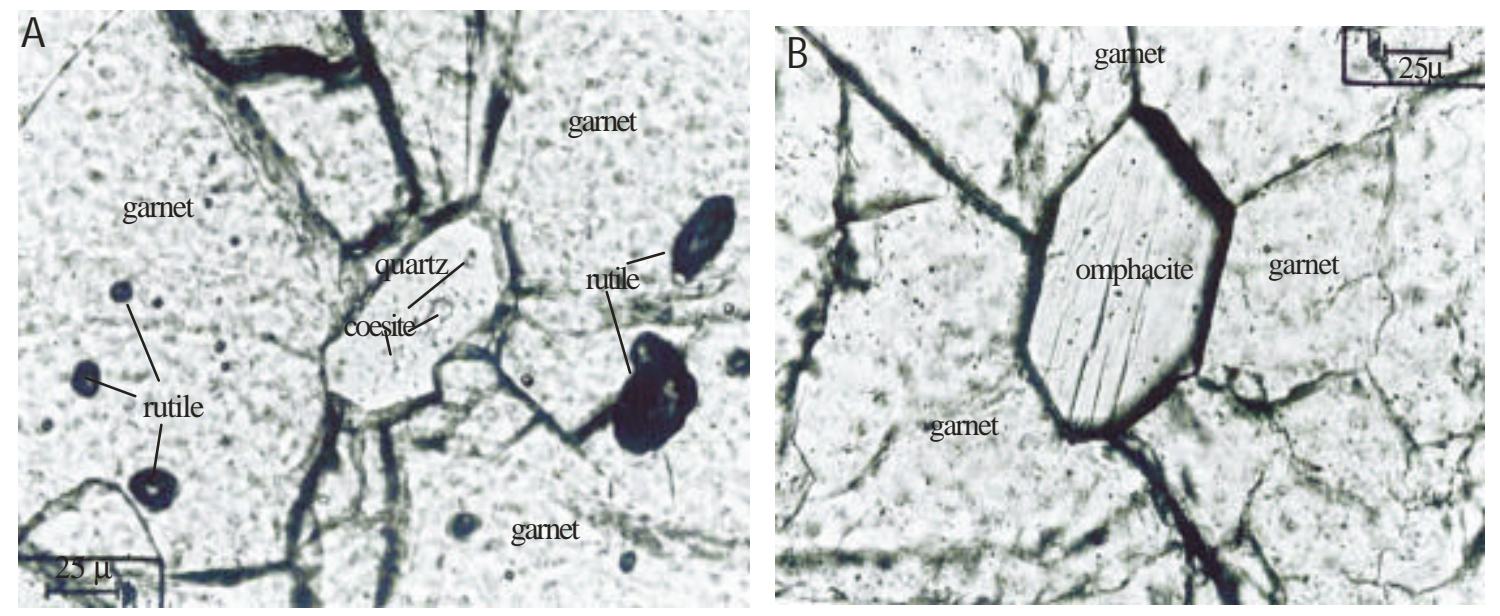

Fig. 4.1A, B Photomicrographs of: A coesite inclusion in garnet, B omphacite inclusion in garnet; note the host garnets of the coesite and omphacite inclusions have similar radiating fractures

DB05 is mainly composed of garnet, omphacite, and minor quartz. Rutile, apatite and zircon occur as accessory minerals. Garnet and omphacite are equigranular in texture. Garnet contains inclusions of omphacite, amphibole, rutile, and coesite. Most omphacites are "fresh"; some have slightly retrograded into amphibole at the very margin of the grains.

DB02 is a retrograded eclogite and consists of garnet, omphacite, quartz, varying phengite, amphibole, plagioclase and zoisite as major components, and rutile, apatite and zircon as accessory minerals. Most omphacite has been replaced by symplectite of amphibole, plagioclase and sodic augite. Coesite and coesite pseudomorphs in garnet and omphacite have been found in some thin sections (Fig. 4.1). Garnet mainly occurs as idioblastic crystals with kelyphitic rims of amphibole and/or porphyroblasts with inclusions of rutile, omphacite, phengite and quartz and/or coesite. Two different textural types of garnet were observed: one is dark red garnet, the other is fine-grained late crystallized orange-yellow garnet. Omphacite occurs as two generations: fine-grained omphacite as inclusions in dark red garnet and coarse-grained matrix 
omphacite coexisting with both types of garnet. Matrix omphacite is partially or completely replaced by symplectite of green amphibole and plagioclase. Phengite occurs either as inclusions in garnet and omphacite, or coarse-grained coexisting with garnet. From textural characteristics, coarse-grained phengite is a stable phase in eclogite coexisting with the other eclogite-facies minerals. Phengite flakes are partially replaced by fine-grained biotite aggregates. Retrograde amphibole can be divided into two generations: amphibole (barroisite) intergrown with symplectic plagioclase and clinopyroxene and, coarse-grained hornblende forming kelyphitic rims around garnet. Most of the quartz is "interstitial" and must have formed from fluids after eclogite-facies metamorphism. Retrograde alteration also resulted in the formation of ilmenite after rutile.

The kyanite-rich eclogite (DB07) is inequigranular in texture and composed of garnet, omphacite, kyanite, quartz and minor phengite and rutile. Quartz pseudomorphs after coesite are found in garnet and in omphacite. The fact that coesite inclusions occur in kyanite at the same locality indicates that kyanite is a primary mineral in eclogite-facies metamorphism (Zhang et al. 1995). In contrast to the matrix quartz in the retrograded eclogite, which was assumed to be formed from interstitial fluids, matrix quartz in kyanite-rich eclogite, as well as the minor quartz in the "fresh" eclogite, commonly shows sharp contacts with garnet, omphacite and kyanite.

The primary assemblage of the garnet peridotite (DB10) is garnet + diopside + enstatite + olivine. Coarse garnet grains have diameters around $1 \mathrm{~mm}$, some are surrounded by fine-grained garnets. Enstatite is sometimes rimmed by fine-grained talc. Olivine has been partially replaced by serpentine.

\subsubsection{Shima UHP eclogite}

Eclogitic samples from Shima are medium-grained and granular in texture and contain a typical eclogite assemblage of garnet, omphacite, rutile. Garnet is the most abundant phase and represents > 50 volume \%. Most garnets range from 1 to $2 \mathrm{~mm}$ in diameter. Some garnets are idioblastic, however, most are irregular grains. Garnet has a few inclusions of omphacite and coesite. Omphacite is very fresh without visible retrogression.

\subsubsection{Jadeite quartzite from Shuanghe}

The Shuanghe jadeite quartzite consists of 30-50 vol \% jadeite, 40-55\% quartz, c. 5\% garnet and minor rutile; lineation is defined by elongated jadeite and garnet grains and by 
stringers of polygonal quartz aggregates. Jadeite and quartz range in size from 1 to $4 \mathrm{~mm}$, whereas garnets are finer grained $(0.5-1.5 \mathrm{~mm})$. Most samples are strongly retrograded; jadeite is almost completely replaced by symplectite of fine-grained amphibole + sodic plagioclase, and garnet is replaced by medium-grained taramite rimmed by a thin albite layer.

Sample DB31 is relatively less altered; jadeite and garnet are well preserved. Jadeites are successively rimmed by thin coronas (0.1-0.2 mm wide) composed of fibrous oligoclase (inner rim), albite (outer rim) and minor Ca-clinopyroxene. Liou et al. (1997) has demonstrated that the kelyphitic reaction corona of jadeite at its contact with quartz consists of a concentric sequence: an inner layer of oligoclase (An15) + minor fibrous amphibole, and an outer layer of albite + fine-grained aegirine-augite. Inclusions of quartz pseudomorphs after coesite can be observed both in garnet and jadeite.

\subsection{4 "Cold” eclogite from Lidu}

Five thin sections from various parts of the eclogite from Lidu were petrologically studied. The mineral assemblage is garnet + omphacite + kyanite + phengite + quartz + paragonite + rutile \pm epidote \pm amphibole \pm feldspar.

Garnets of Lidu eclogite are poikiloblastic and range from 2 to $10 \mathrm{~mm}$ in size. Some of the coarse-grained garnets contain abundant inclusions of epidote, rutile and phengite in the core, whereas omphacite, phengite in the mantle. However, the garnet margin is usually free of inclusions. Many inclusions in garnet form snow-ball textures. Such a texture indicates a threestage growth history of garnet: an early original garnet core, snow-ball hydroxyl-bearing mineral inclusions, and a late regrowth garnet core and margin. Most garnet grains are surrounded by a thin rim of symplectic amphibole, albite, and epidote. Coesite or quartz pseudomorph after coesite were not found.

Omphacites are relatively fine-grained compared to the garnets and $<1 \mathrm{~mm}$ in diameter. Most of the omphacites are rimmed by symplectic clinopyroxene, amphibole and albite due to retrograde metamorphism. The relict of omphacite sometimes contain minor mineral inclusions. However, omphacite inclusions in garnet, if any, do not show signs of retrogression.

Kyanites are stable with garnets, omphacites, and phengites. The coarse-grained kyanite is common in the matrix and sometimes is partially replaced by paragonite. The presence of paragonite around kyanite indicates a pressure of $18 \mathrm{kbar}$ at $635{ }^{\circ} \mathrm{C}$ by the reaction of jadeite + kyanite $+\mathrm{H}_{2} \mathrm{O}=$ paragonite (Okay, 1993). A thin rim of quartz is also sometimes present around kyanite. On the other hand, kyanite is sometimes locally replaced by coarse-grained aggregates 
of paragonite, which, however, is locally replaced by a fine-grained symplectite consisting of an intergrowth of corundum + albite (Fig. 4.2).

Phengites are found as inclusions in garnet and in the matrix. Coarse-grained phengites have usually been partially replaced by biotite. However, many phengite inclusions in garnet are also coarse-grained and idioblastic.

Other phases in Lidu eclogite include epidote, amphibole, rutile, apatite, quartz, talc and corundite (see Table 4.4 and Fig. 4.2). Two kinds of epidote can be identified based on their texture relations: one occurs as isolated coarse-grained crystals, and the other occurs as fine and irregular grains and as symplectite after garnet. The first kind is assumed to represent phases formed under blueschist and eclogite facies metamorphism, whereas the second kind probably represents a retrograde product. Similarly, amphiboles occur also in such two kinds: coarsegrained amphibole surrounding garnets and symplectite with clinopyroxene and albite after omphacite. Rutile and apatite generally occur as inclusions in garnets. Quartz is ubiquitous in the matrix and as inclusions in garnets.

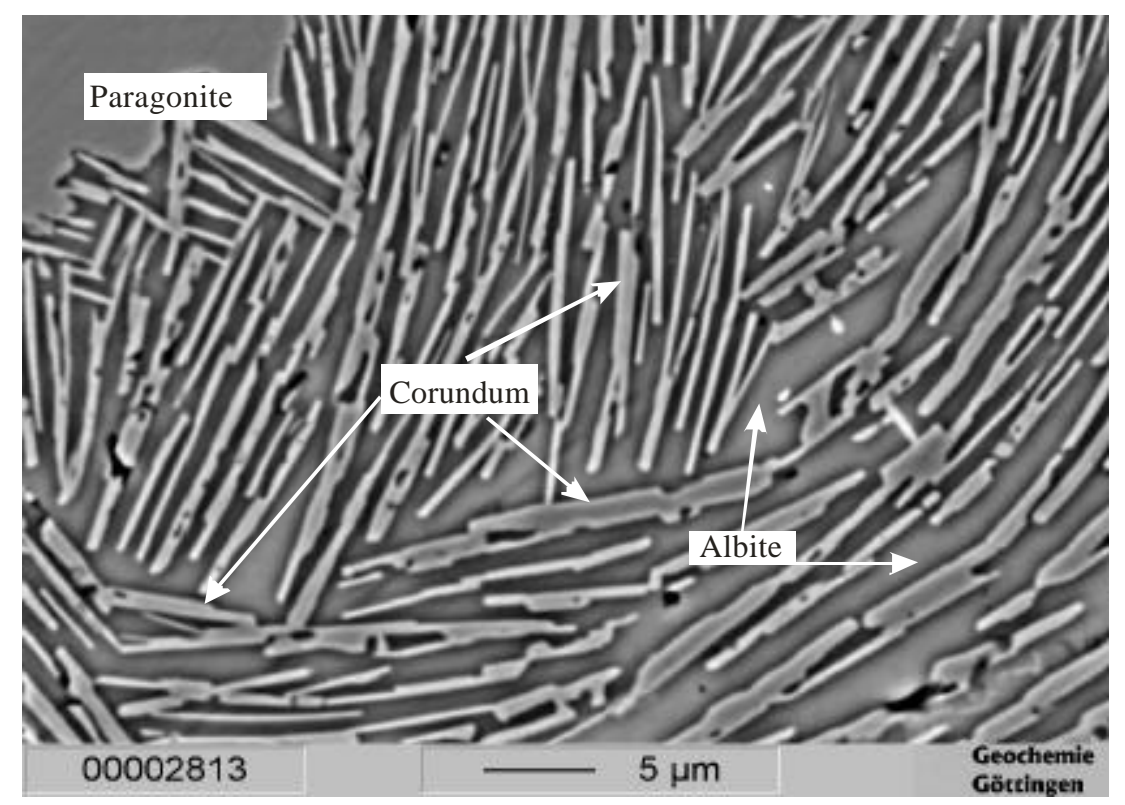

Fig. 4.2.Photomicrograph of the eclogite from Lidu showing that paragonite is locally replaced by corundum and albite.

\subsubsection{Eclogite in Raobazhai}

The garnet pyroxenite is composed mainly of the primary phases garnet (c. 40\%) and clinopyroxene (20-30\%), and secondary phases Tiamphibole (10-15\%), plagioclase (10-15\%) 
and minor orthopyroxene. Rutile \pm ilmenite and apatite occur as accessory minerals. Most garnet crystals are relatively large ranging from 2 to $8 \mathrm{~mm}$. Some garnet grains inferred to be originally in contact with clinopyroxene are surrounded by thin coronae of plagioclase and amphibole. Usually garnet contains pyroxene, amphibole, plagioclase, rutile and/or ilmenite as inclusions. Pyroxene occurs as inclusions in garnet or as a rock-forming mineral in the matrix. Most pyroxenes are $<1 \mathrm{~mm}$ in size and thus finer grained than garnet. Some are partially retrograded into netlike texture that is composed of clinopyroxene and plagioclase (Fig. 4.3a). Secondary reddish brown amphibole is inequigranular, and sometimes contains inclusions of early-formed minerals, such as garnet and pyroxene. Plagioclase sometimes occurs as inclusions in garnet and clinopyroxene; most form a symplectite retrograded from clinopyroxene. Orthopyroxene occurs as an overgrowth phase of clinopyroxene, or a needle-like exsolution in clinopyroxene, indicating that orthopyroxene formed later than clinopyroxene (Fig. 4.3b). Rutile occurs mainly as inclusions in garnet and clinopyroxene, some of them have retrograded into ilmenite.

\subsubsection{Granulite in Yanzihe}

The granulite sample from Yanzihe is characterized by a moderate amount of quartz in addition to the granulite facies assemblage of garnet + hypersthene. It is principally composed of garnet $(\sim 34 \%)$, quartz $(\sim 36 \%)$, hypersthene $(\sim 15 \%)$, amphibole $(\sim 7 \%)$, magnetite $(\sim 5 \%)$ and biotite $(\sim 2 \%)$. Accessory minerals include apatite and minor ilmenite. The rock has gneissic fabric and concordant felsic bands. Foliation is defined by biotite and hypersthene.

Garnets are porphyroblasts ( 2 to $8 \mathrm{~mm}$ in diameter) with a few inclusions of quartz that occur in cores of garnets. No visible hypersthene, biotite or plagioclase inclusions appear in garnets. Some hypersthenes in the matrix have dark and hair-like structure on the surfaces, which are probably from retrogression. Hypersthenes are usually smaller than $2 \mathrm{~mm}$ and rarely include some other minerals such as biotite. It is important to note that some amphiboles have Clcontent up to $4 \%$ (see section 4.5 ). 


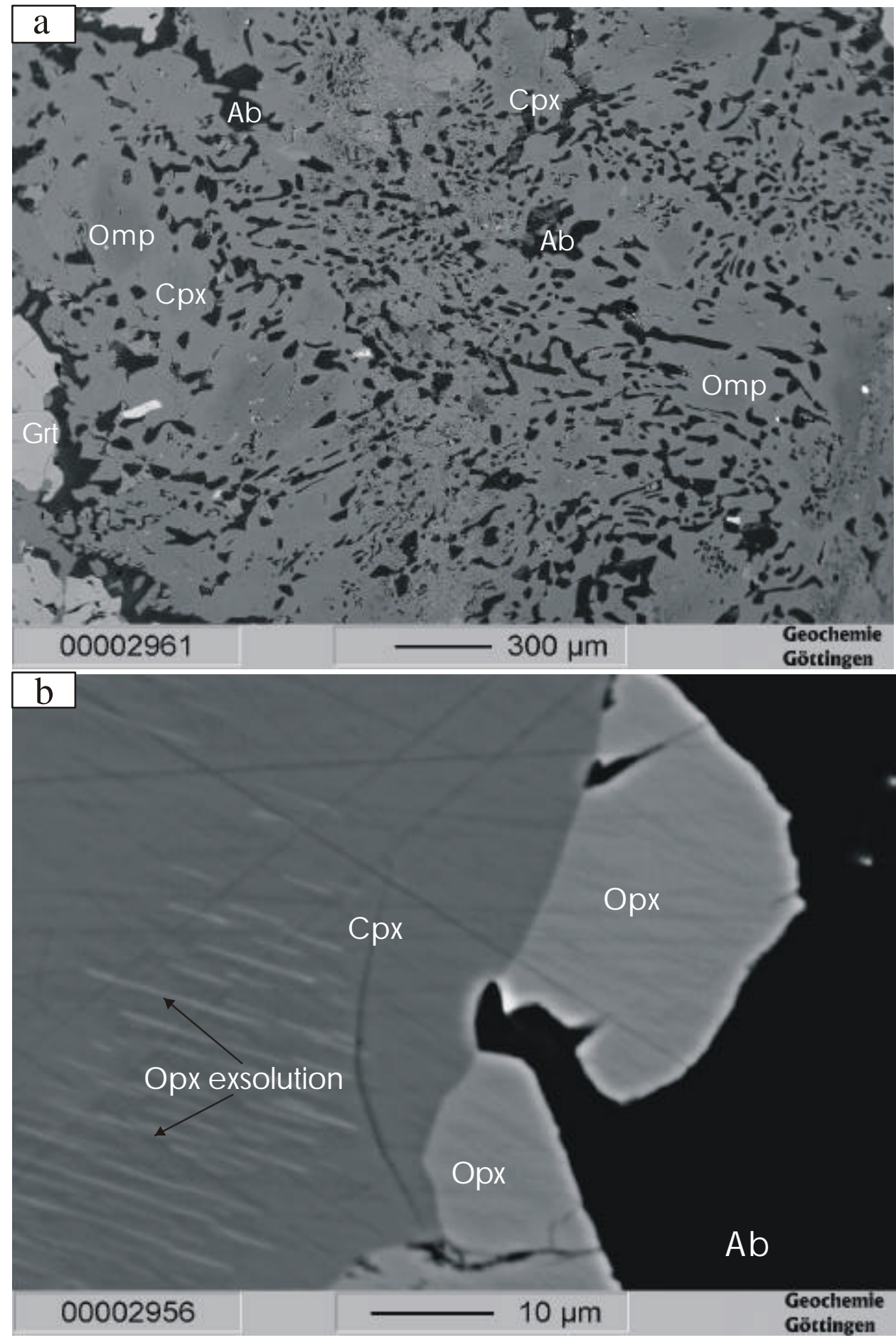

Fig. 4.3. Photomicrographs of the eclogite from Raobazhai (a) Coarse symplectite of secondary clinopyroxene and albite around primary omphacite. (b) Overgrowth of orthopyroxene (hypersthene) around clinopyroxene (see also Fig. 4.3a); note the needle -like exsolution of orthopyroxene at the margin. Abbreviations are after Kretz, 1983) 


\subsection{Mineral Chemistry}

\subsubsection{Garnet}

Every sample investigated contains garnet but differences in grain size, distribution, texture, inclusion density are large as described above. Representative garnet compositions are given in Table 4.2 and plotted in terms of mole per cent pyrope, almandine + spessartine and grossular in Fig. 4.4. There is clearly a large compositional range (Alm24-66 Prp10-57 Grs1039Spe1-5), resulting mainly from variations of bulk composition and mineral assemblage of their host rocks.

Garnets in the four samples from Bixiling have quite different compositions: "fresh" and retrograded eclogites are rich in almandine (50-60 mole\%); garnets in kyanite-rich eclogite have more or less the same contents of grossular, pyrope and almandine, whereas garnets in peridotite are mainly composed of pyrope (50-60 mole\%). Garnets in granulite from Yanzihe and in jideite quartzite from Shuanghe have the highest almandine contents up to 65-66 and 57-60 mole\% respectively. Garnets from Lidu and \% Raobazhai show strong compositional zonations (see section 4.3 for details)

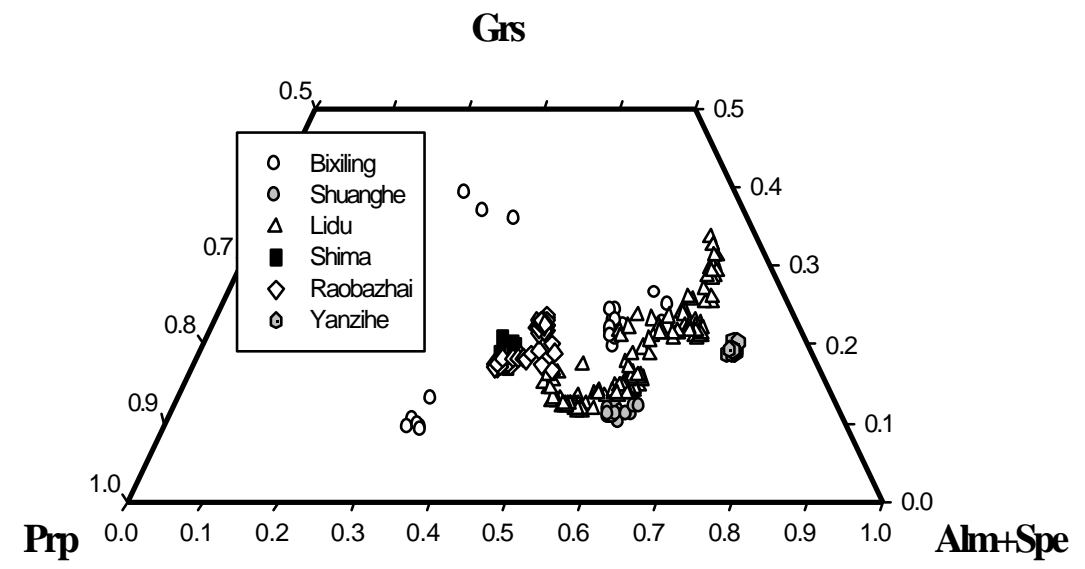

Fig. 4.4. Compositional variations of the garnets in granulite (Yanzihe), jadeite quartzite (Shuanghe) and eclogites (others) from Dabie Shan. Note garnets from Bixiling display a large compositional variation as these garnets are from different rock types; compositional zonations are detected in garnets from Lidu and Raobazhai. 


\subsubsection{Clinopyroxene}

The representative compositions of clinopyroxenes of various samples from Dabie Shan are given in Table 4.3 and plotted in the $\mathrm{Jd}-\mathrm{Ac}-\mathrm{Di}+\mathrm{Hd}$ diagram (Fig. 4.5). The analyzed clinopyroxenes are impure jadeite (Essene and Fyfe, 1967) in the jadeite quartzite from Shuanghe, omphacite in eclogites from Bixiling and Shima. In eclogite from Bixiling (DB02), omphacites that occur as inclusions in garnets have higher jadeite-content $\left(>\mathrm{Jd}_{60}\right)$ than porphyroblastic omphacites coexisting with garnet (Jd 55-60); furthermore, some omphacite inclusions in Bixiling eclogite have significant $\mathrm{K}_{2} \mathrm{O}$ contents (see below for detail). Clinopyroxene grains in eclogite from Raobazhai show strong compositional zonations with an omphacitic core and a diopsidic rim. In eclogite from Lidu, compositions of clinopyroxene inclusions in garnet are different from those of matrix omphacite (Table 3 and Fig. 4.5). All analyzed clinopyroxenes are poor in $\mathrm{TiO}_{2}(<0.2 \%), \mathrm{Cr}_{2} \mathrm{O}_{3}(<0.2 \%)$ and $\mathrm{MnO}(0.1 \%)$.

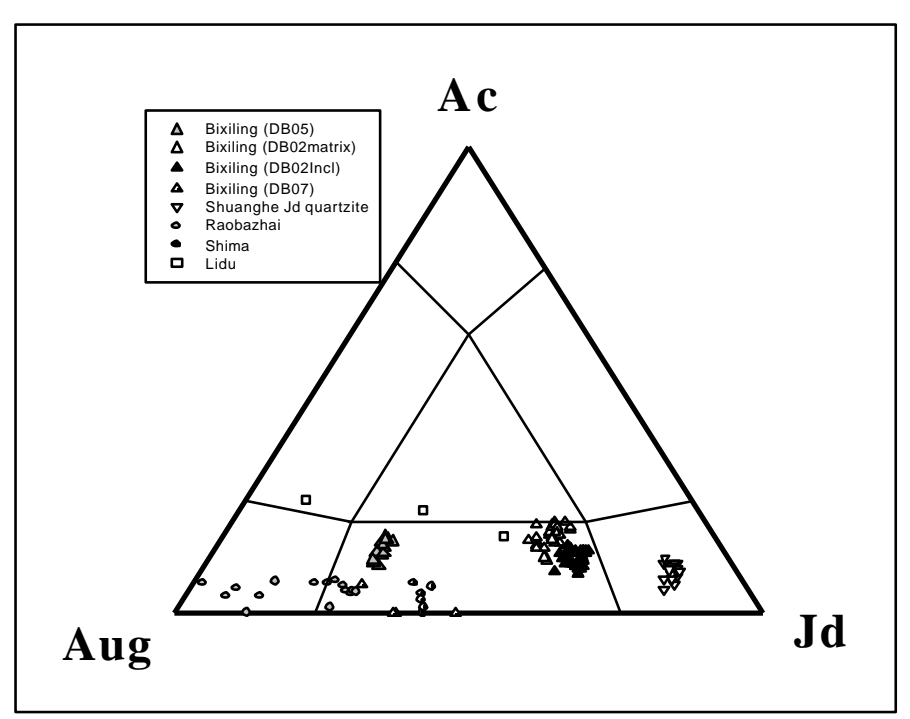

\footnotetext{
Fig. 4.5 Chemical composition diagram for clinopyroxenees of investigated samples
}

\subsubsection{Amphibole}

All samples contain amphiboles in variable proportions with a wide range in composition corresponding to edenite, hornblende, and pargasite fields (classification after Leake et al., 1997). Table 4.4 reports selected analyses of amphiboles. Figure 4.6 shows the various compositions in terms of $\mathrm{X}_{\mathrm{Mg}}[=\mathrm{Mg} /(\mathrm{Mg}+\mathrm{Fe})]$ versus $\mathrm{Si}$ per formula unit. Amphibole structural formula were calculated assuming the sum of tetrahedrat plus M1-, M2- and M3-sites equals 13. Cosca et al. (1991) demonstrated that this normalization scheme gives the best approximation to true amphibole compositions. Molecular proportions of $\mathrm{OH}$ and equivalent $\mathrm{H}_{2} \mathrm{O}$ contents in amphibole were calculated with the assumption $\mathrm{OH}=2-\mathrm{Cl}-\mathrm{F}$. 


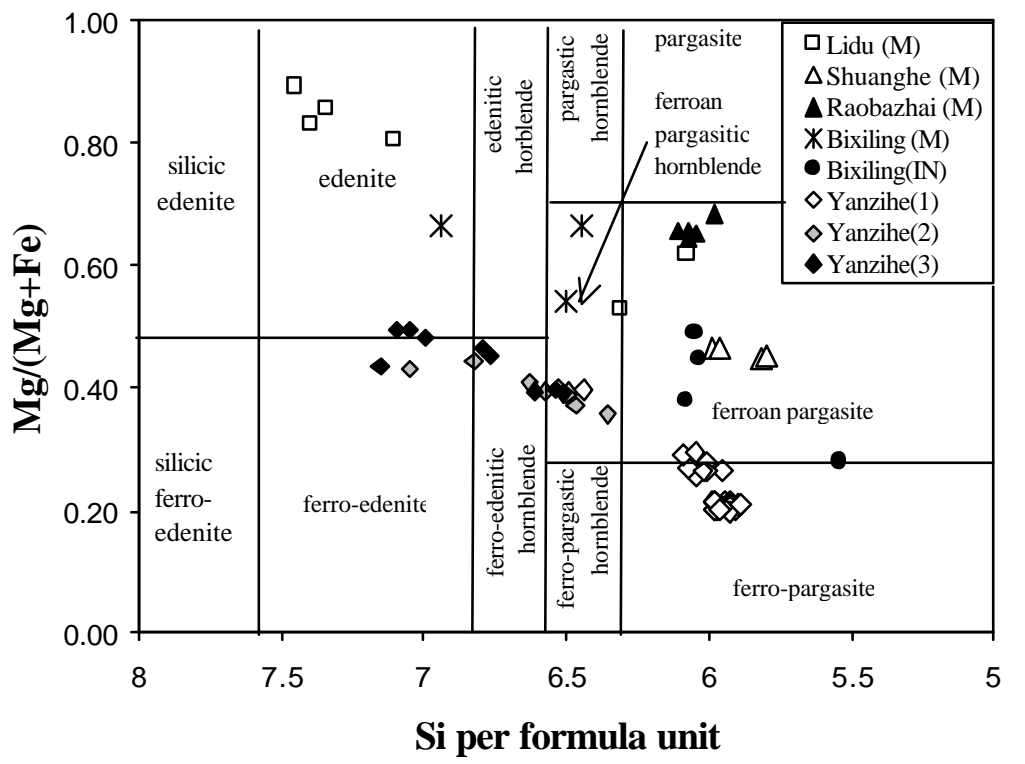

Fig.4.6. Amphibole data plotted in the amphibole classification diagram of Leake et al (1997). M: amphiboles in matrix; IN: amphibole inclusions in garnet; Yanzihe(1): amphiboles that contain $\mathrm{Cl}>1 \%$; Yanzihe(2) amphiboles that contain $0.3<\mathrm{Cl}<1.0 \%$; Yanzihe(3) amphiboles that contain $\mathrm{Cl}<0.3 \%$.

Four groups are distinguished. The first corresponds to secondary matrix amphiboles in the Lidu eclogite. The second includes secondary amphiboles from the Raobazhai eclogite, the Shuanghe jadeite quartzite and possible primary amphibole inclusions in garnet from Bixiling. The third consists of texturally late amphiboles from Bixiling. The fourth group is composed of amphiboles with various $\mathrm{Cl}$ contents from granulite in Yanzihe, which will be discussed further in section 4.5.

\subsection{Mineral compositional zonations}

The study of zoned crystals has been an active area of research in petrology since the advent of the electron microprobe in the 1960's, which permitted rapid microchemical analysis with spatial resolution on the order of $1 \mu \mathrm{m}$. Zoned crystals are thought of as a chemical tape recorder in which the history of the chemical evolution of the sample is recorded in the variation of elements (Spear,1993).

As mentioned above, garnet can be found in all the investigated samples; some garnets in eclogites from Lidu and Raobazhai and in granulite from Yanzihe are up to >10, 8 and $8 \mathrm{~mm}$ respectively, whereas garnets from eclogites in Bixiling, Shima and jadeite quartzite from Shuanghe are finer grains $(<2 \mathrm{~mm})$. Microprobe profile analyses and semi-quantitative mapping indicate that compositional zoning have been well preserved in garnet from Lidu, and in garnet 
Table 4.2 Representative microprobe analyses of garnet (Gt1, dark-red garnet; Gt2, orange-yellow garnet)

\begin{tabular}{|c|c|c|c|c|c|c|c|c|c|c|c|c|c|c|}
\hline Locality & Bixiling & & & & & & & & & & Shima & & & \\
\hline Sample & DB02 & & & & DB05 & & DB07 & & DB10 & & DB63 & & & \\
\hline No. & 1 & 2 & 3 & 4 & 5 & 6 & 7 & 8 & 9 & 10 & 11 & 12 & 13 & 14 \\
\hline Mineral & $\begin{array}{c}\text { Gt1 } \\
\text { (core) }\end{array}$ & $\begin{array}{c}\text { Gt1 } \\
\text { (rim) }\end{array}$ & $\begin{array}{c}\text { Gt2 } \\
\text { (core) }\end{array}$ & $\begin{array}{r}\mathrm{Gt} 2 \\
\text { (rim) }\end{array}$ & (core) & (rim) & (core) & (rim) & (core) & (rim) & (core) & (rim) & (core) & (rim) \\
\hline $\mathrm{SiO}_{2}$ & 38.85 & 38.59 & 38.76 & 38.92 & 39.19 & 39.37 & 40.45 & 40.57 & 40.89 & 40.69 & 39.80 & 39.77 & 40.01 & 39.70 \\
\hline $\mathrm{TiO}_{2}$ & 0.01 & 0.03 & 0.07 & 0.05 & 0.08 & 0.03 & 0.05 & 0.032 & 0.02 & 0.02 & 0.16 & 0.02 & 0.00 & 0.00 \\
\hline $\mathrm{Ab}_{2} \mathrm{O}_{3}$ & 21.68 & 21.60 & 21.46 & 21.78 & 21.58 & 21.55 & 22.40 & 22.46 & 21.99 & 22.28 & 22.35 & 22.68 & 22.77 & 22.62 \\
\hline $\mathrm{Cr}_{2} \mathrm{O}_{3}$ & b.d. & b.d & 0.02 & 0.02 & 0.00 & 0.04 & 0.06 & 0.00 & 0.80 & 0.44 & 0.02 & 0.00 & 0.00 & 0.15 \\
\hline $\mathrm{FeO}$ & 27.45 & 27.98 & 26.25 & 25.93 & 25.27 & 25.45 & 13.59 & 14.04 & 16.75 & 16.96 & 18.84 & 18.34 & 17.81 & 19.24 \\
\hline $\mathrm{MnO}$ & 0.99 & 0.96 & 0.98 & 0.91 & 0.36 & 0.42 & 0.38 & 0.34 & 0.50 & 0.45 & 0.55 & 0.46 & 0.64 & 0.27 \\
\hline $\mathrm{MgO}$ & 4.61 & 4.22 & 3.96 & 4.39 & 6.15 & 6.46 & 9.29 & 9.10 & 15.52 & 15.47 & 10.31 & 10.97 & 10.53 & 10.29 \\
\hline $\mathrm{CaO}$ & 7.96 & 8.12 & 9.68 & 9.58 & 8.59 & 8.34 & 13.97 & 13.64 & 3.64 & 4.03 & 7.54 & 6.94 & 7.64 & 7.31 \\
\hline $\mathrm{Na}_{2} \mathrm{O}$ & 0.05 & 0.03 & 0.03 & 0.08 & 0.00 & 0.02 & 0.05 & 0.08 & 0 & 0.04 & 0.05 & 0.00 & 0.12 & 0.00 \\
\hline $\mathrm{K}_{2} \mathrm{O}$ & b.d. & b.d. & b.d. & 0.01 & 0.01 & 0.01 & 0.01 & 0.02 & 0 & 0 & 0.06 & 0.00 & 0.00 & 0.01 \\
\hline Total & 101.60 & 101.55 & 101.21 & 101.67 & 101.23 & 101.69 & 100.25 & 100.28 & 100.11 & 100.38 & 99.68 & 99.18 & 99.52 & 99.59 \\
\hline $\mathrm{Si}$ & 3.00 & 2.99 & 3.00 & 2.99 & 3.00 & 3.00 & 3.01 & 3.02 & 3.00 & 2.98 & 3.00 & 3.00 & 3.01 & 3.00 \\
\hline $\mathrm{Ti}$ & 0.00 & 0.00 & 0.00 & 0.00 & 0.01 & 0.00 & 0.00 & 0.00 & 0.00 & 0.00 & 0.01 & 0.00 & 0.00 & 0.00 \\
\hline $\mathrm{Al}$ & 1.97 & 1.97 & 1.96 & 1.97 & 1.95 & 1.93 & 1.96 & 1.97 & 1.90 & 1.92 & 1.99 & 2.02 & 2.02 & 2.01 \\
\hline $\mathrm{Cr}$ & 0.00 & 0.00 & 0.00 & 0.00 & 0.00 & 0.00 & 0.00 & 0.00 & 0.05 & 0.03 & 0.00 & 0.00 & 0.00 & 0.01 \\
\hline $\mathrm{Fe}^{3+}$ & 0.04 & 0.05 & 0.03 & 0.05 & 0.04 & 0.07 & 0.02 & 0.00 & 0.04 & 0.10 & 0.01 & 0.00 & 0.00 & 0.00 \\
\hline $\mathrm{Fe}^{2+}$ & 1.73 & 1.76 & 1.68 & 1.62 & 1.57 & 1.55 & 0.83 & 0.87 & 0.99 & 0.94 & 1.18 & 1.16 & 1.12 & 1.21 \\
\hline $\mathrm{Mn}$ & 0.07 & 0.06 & 0.06 & 0.06 & 0.03 & 0.03 & 0.02 & 0.02 & 0.03 & 0.03 & 0.03 & 0.03 & 0.04 & 0.02 \\
\hline $\mathrm{Mg}$ & 0.53 & 0.49 & 0.46 & 0.50 & 0.75 & 0.73 & 1.03 & 1.01 & 1.70 & 1.69 & 1.16 & 1.23 & 1.18 & 1.16 \\
\hline $\mathrm{Ca}$ & 0.66 & 0.67 & 0.80 & 0.79 & 0.65 & 0.68 & 1.11 & 1.09 & 0.29 & 0.32 & 0.61 & 0.56 & 0.62 & 0.59 \\
\hline $\mathrm{Na}$ & 0.01 & 0.01 & 0.01 & 0.01 & 0.00 & 0.00 & 0.01 & 0.01 & 0.00 & 0.01 & 0.01 & 0.00 & 0.02 & 0.00 \\
\hline $\mathrm{K}$ & 0.00 & 0.00 & 0.00 & 0.00 & 0.00 & 0.00 & 0.00 & 0.00 & 0.00 & 0.00 & 0.01 & 0.01 & 0.00 & 0.00 \\
\hline Total & 8.00 & 8.00 & 8.00 & 8.00 & 8.00 & 8.00 & 8.00 & 8.00 & 8.00 & 8.00 & 8.01 & 8.01 & 8.01 & 8.01 \\
\hline Prp & 0.18 & 0.16 & 0.15 & 0.17 & 0.24 & 0.24 & 0.34 & 0.34 & 0.57 & 0.57 & 0.39 & 0.41 & 0.40 & 0.39 \\
\hline Grs & 0.22 & 0.23 & 0.27 & 0.27 & 0.23 & 0.21 & 0.37 & 0.36 & 0.10 & 0.10 & 0.20 & 0.19 & 0.21 & 0.20 \\
\hline Alm & 0.58 & 0.59 & 0.56 & 0.55 & 0.52 & 0.54 & 0.28 & 0.29 & 0.33 & 0.32 & 0.40 & 0.39 & 0.38 & 0.41 \\
\hline Spe & 0.02 & 0.02 & 0.02 & 0.02 & 0.01 & 0.01 & 0.01 & 0.01 & 0.01 & 0.01 & 0.01 & 0.01 & 0.01 & 0.01 \\
\hline
\end{tabular}


Table 4.2 (continued)

\begin{tabular}{|c|c|c|c|c|c|c|c|c|c|c|c|c|c|c|c|}
\hline \multirow{3}{*}{$\begin{array}{c}\text { Locality } \\
\text { Sample } \\
\text { Nr }\end{array}$} & \multicolumn{4}{|l|}{ Shuanghe } & \multicolumn{5}{|l|}{ Lidu } & \multicolumn{4}{|c|}{ Raobazhai } & \multicolumn{2}{|l|}{ Yanzihe } \\
\hline & DB31 & & & & DB44 & & & Db45 & & & R14 & & & Y1 & \\
\hline & 15 & 16 & 17 & 18 & 19 & 20 & 21 & 22 & 23 & 24 & 25 & 26 & 27 & 28 & 29 \\
\hline Mineral & (rim) & (core) & & & rim & center & core & rim & center & core & rim & center & core & rim & core \\
\hline $\mathrm{SiO}_{2}$ & 39.49 & 39.49 & 39.57 & 39.56 & 37.94 & 38.88 & 39.74 & 38.38 & 38.69 & 40.04 & 40.54 & 40.11 & 40.68 & 37.53 & 37.44 \\
\hline $\mathrm{TiO}_{2}$ & 0.00 & 0.01 & 0.05 & 0.00 & 0.03 & 0.12 & 0.00 & 0.02 & 0.11 & 0.01 & 0.04 & 0.05 & 0.00 & 0.02 & 0.047 \\
\hline $\mathrm{Al}_{2} \mathrm{O}_{3}$ & 21.86 & 22.28 & 22.12 & 22.17 & 21.20 & 21.77 & 22.59 & 21.32 & 21.39 & 22.36 & 22.61 & 22.02 & 22.52 & 21.23 & 21.66 \\
\hline $\mathrm{Cr}_{2} \mathrm{O}_{3}$ & 0.00 & 0.01 & 0.00 & 0.00 & 0.00 & 0.02 & 0.00 & 0.00 & 0.02 & 0.02 & 0.11 & 0.06 & 0.06 & 0.00 & 0.00 \\
\hline $\mathrm{FeO}$ & 27.40 & 27.58 & 28.01 & 27.85 & 28.06 & 27.46 & 23.58 & 28.63 & 29.74 & 24.08 & 20.05 & 21.19 & 19.74 & 30.59 & 30.43 \\
\hline $\mathrm{MnO}$ & 0.44 & 0.42 & 0.40 & 0.43 & 1.00 & 0.34 & 0.48 & 0.86 & 0.39 & 0.49 & 0.42 & 0.62 & 0.43 & 2.46 & 2.52 \\
\hline $\mathrm{MgO}$ & 7.80 & 7.81 & 7.56 & 7.89 & 1.58 & 5.43 & 9.89 & 1.86 & 3.59 & 9.96 & 11.61 & 9.20 & 11.70 & 2.56 & 2.57 \\
\hline $\mathrm{CaO}$ & 4.58 & 4.46 & 4.17 & 4.04 & 11.90 & 7.46 & 5.58 & 10.78 & 7.87 & 4.93 & 6.48 & 8.45 & 6.50 & 6.89 & 6.72 \\
\hline $\mathrm{Na}_{2} \mathrm{O}$ & 0.05 & 0.06 & 0.03 & 0.06 & 0.00 & 0.02 & 0.02 & 0.00 & 0.00 & 0.00 & 0.01 & 0.02 & 0.01 & 0.02 & 0 \\
\hline $\mathrm{K}_{2} \mathrm{O}$ & 0.01 & 0.00 & 0.00 & 0.01 & 0.00 & 0.00 & 0.00 & 0.00 & 0.01 & 0.01 & 0.00 & 0.01 & 0.00 & 0.01 & 0 \\
\hline Total & 101.62 & 102.12 & 101.90 & 102.01 & 101.71 & 101.50 & 101.88 & 101.85 & 101.81 & 101.90 & 101.88 & 101.72 & 101.64 & 101.31 & 101.39 \\
\hline $\mathrm{Si}$ & 3.00 & 2.99 & 3.01 & 3.00 & 2.97 & 2.99 & 2.96 & 3.00 & 3.01 & 2.99 & 2.98 & 2.99 & 3.00 & 2.97 & 2.95 \\
\hline $\mathrm{Ti}$ & 0.00 & 0.00 & 0.00 & 0.00 & 0.00 & 0.01 & 0.00 & 0.00 & 0.01 & 0.00 & 0.00 & 0.00 & 0.00 & 0.00 & 0.00 \\
\hline $\mathrm{Al}$ & 1.96 & 1.99 & 1.98 & 1.98 & 1.95 & 1.97 & 1.99 & 1.96 & 1.96 & 1.97 & 1.96 & 1.94 & 1.96 & 1.98 & 2.01 \\
\hline $\mathrm{Cr}$ & 0.00 & 0.00 & 0.00 & 0.00 & 0.00 & 0.00 & 0.00 & 0.00 & 0.00 & 0.00 & 0.01 & 0.00 & 0.00 & 0.00 & 0.00 \\
\hline $\mathrm{Fe}^{3+}$ & 0.04 & 0.04 & 0.00 & 0.03 & 0.11 & 0.03 & 0.09 & 0.04 & 0.02 & 0.05 & 0.06 & 0.07 & 0.05 & 0.11 & 0.09 \\
\hline $\mathrm{Fe}^{2+}$ & 1.70 & 1.70 & 1.78 & 1.73 & 1.72 & 1.73 & 1.38 & 1.82 & 1.92 & 1.46 & 1.17 & 1.25 & 1.17 & 1.90 & 1.92 \\
\hline $\mathrm{Mn}$ & 0.03 & 0.03 & 0.03 & 0.03 & 0.07 & 0.02 & 0.03 & 0.06 & 0.03 & 0.03 & 0.03 & 0.04 & 0.03 & 0.16 & 0.17 \\
\hline $\mathrm{Mg}$ & 0.88 & 0.88 & 0.86 & 0.89 & 0.18 & 0.62 & 1.10 & 0.22 & 0.42 & 1.11 & 1.27 & 1.02 & 1.29 & 0.30 & 0.30 \\
\hline $\mathrm{Ca}$ & 0.37 & 0.36 & 0.34 & 0.33 & 1.00 & 0.61 & 0.45 & 0.90 & 0.65 & 0.39 & 0.51 & 0.68 & 0.51 & 0.58 & 0.57 \\
\hline $\mathrm{Na}$ & 0.01 & 0.01 & 0.00 & 0.01 & 0.00 & 0.00 & 0.00 & 0.00 & 0.00 & 0.00 & 0.00 & 0.00 & 0.00 & 0.00 & 0.00 \\
\hline $\mathrm{K}$ & 0.00 & 0.00 & 0.00 & 0.00 & 0.00 & 0.00 & 0.00 & 0.00 & 0.00 & 0.00 & 0.00 & 0.00 & 0.00 & 0.00 & 0.00 \\
\hline Total & 7.99 & 7.99 & 8.00 & 8.00 & 8.00 & 7.98 & 8.00 & 8.00 & 8.02 & 8.00 & 7.99 & 7.99 & 8.01 & 8.00 & 8.01 \\
\hline Prp & 0.30 & 0.30 & 0.29 & 0.30 & 0.06 & 0.21 & 0.37 & 0.07 & 0.14 & 0.37 & 0.43 & 0.34 & 0.43 & 0.10 & 0.10 \\
\hline Grs & 0.12 & 0.12 & 0.11 & 0.11 & 0.34 & 0.21 & 0.15 & 0.30 & 0.22 & 0.13 & 0.17 & 0.23 & 0.17 & 0.20 & 0.19 \\
\hline Alm & 0.57 & 0.57 & 0.59 & 0.58 & 0.58 & 0.58 & 0.47 & 0.61 & 0.64 & 0.49 & 0.39 & 0.42 & 0.39 & 0.64 & 0.65 \\
\hline Spe & 0.01 & 0.01 & 0.01 & 0.01 & 0.02 & 0.01 & 0.01 & 0.02 & 0.01 & 0.01 & 0.01 & 0.01 & 0.01 & 0.06 & 0.06 \\
\hline
\end{tabular}


Table 4.3. Representative microprobe analyses of pyroxene ( $\mathrm{Cpx}_{\mathrm{in}}$ clinopyroxene inclusions in garnet)

\begin{tabular}{|c|c|c|c|c|c|c|c|c|c|c|c|c|c|c|}
\hline Locality & Bixiling & & & & & & & & & & & Shima & & \\
\hline sample & DB02 & & & & & DB05 & & DB07 & & DB 10 & & Db63 & & \\
\hline $\mathrm{Nr}$ & 1 & 2 & 3 & 4 & 5 & 6 & 7 & 8 & 9 & 10 & 11 & 12 & 13 & 14 \\
\hline Min: & $\begin{array}{l}\text { Cpx } \\
\text { (core) }\end{array}$ & $\begin{array}{c}\text { Cpx } \\
\text { (rim) }\end{array}$ & $\begin{array}{c}\mathrm{Cpx}_{\mathrm{in}} \\
(\mathrm{rim})\end{array}$ & $\begin{array}{l}\mathrm{Cpx}_{\text {in }} \\
\text { (mid) }\end{array}$ & $\begin{array}{l}\mathrm{Cpx}_{\mathrm{in}} \\
\text { (core) }\end{array}$ & $\begin{array}{c}\text { Cpx } \\
\text { (core) }\end{array}$ & $\begin{array}{c}\mathrm{Cpx} \\
\text { (rim) }\end{array}$ & $\begin{array}{l}\mathrm{Cpx} \\
\text { (rim) }\end{array}$ & $\begin{array}{l}\text { Cpx } \\
\text { (core) }\end{array}$ & Cpx & Opx & & & \\
\hline $\mathrm{SiO}_{2}$ & 57.25 & 57.0 & 57.89 & 57.6 & 56.67 & 56.09 & 56.07 & 55.15 & 56.05 & 55.51 & 57.17 & 56.6 & 57.19 & 56.57 \\
\hline $\mathrm{TiO}_{2}$ & 0.02 & 0.07 & 0.03 & 0.07 & 0.07 & 0.02 & 0.05 & 0.06 & 0.06 & 0.01 & 0.01 & 0.04 & 0.12 & 0.12 \\
\hline $\mathrm{Al}_{2} \mathrm{O}_{3}$ & 14.35 & 13.91 & 15.30 & 15.29 & 14.94 & 6.7 & 6.55 & 6.62 & 6.87 & 1.06 & 0.09 & 8.82 & 8.42 & 8.62 \\
\hline $\mathrm{Cr}_{2} \mathrm{O}_{3}$ & 0.02 & b.d. & 0.02 & 0.01 & 0.02 & 0.05 & 0.08 & 0.047 & 0.056 & 0.49 & 0.02 & 0.09 & 0.12 & 0.00 \\
\hline $\mathrm{FeO}$ & 6.04 & 6.30 & 6.24 & 6.36 & 6.17 & 6.11 & 6.73 & 6.92 & 6.97 & 4.3 & 8.87 & 2.93 & 3.6 & 3.78 \\
\hline $\mathrm{MnO}$ & 0.04 & 0.05 & 0.03 & 0.05 & 0.04 & 0.02 & 0.02 & 0.007 & 0.017 & 0.08 & 0.08 & 0.00 & 0.00 & 0.06 \\
\hline $\mathrm{MgO}$ & 4.84 & 5.03 & 3.92 & 4.05 & 4.30 & 10.5 & 10.23 & 9.94 & 9.9 & 15.94 & 33.72 & 9.61 & 9.69 & 9.46 \\
\hline $\mathrm{CaO}$ & 7.63 & 8.12 & 6.03 & 6.21 & 6.93 & 15.94 & 15.43 & 15.02 & 15.37 & 21.14 & 0.09 & 14.88 & 14.83 & 14.49 \\
\hline $\mathrm{Na}_{2} \mathrm{O}$ & 10.5 & 10.3 & 10.73 & 10.94 & 11.1 & 5.54 & 5.77 & 5.7 & 5.78 & 1.53 & 0.00 & 6.09 & 6.35 & 6.24 \\
\hline $\mathrm{K}_{2} \mathrm{O}$ & b.d. & b.d & 1.08 & 0.44 & 0.01 & 0.01 & 0.05 & 0.00 & 0.01 & 0.01 & 0.00 & 0.00 & 0.04 & 0.00 \\
\hline Total & 100.68 & 100.77 & 101.28 & 101.1 & 100.24 & 100.98 & 100.98 & 99.46 & 101.08 & 100.07 & 100.05 & 99.06 & 100.36 & 99.34 \\
\hline $\mathrm{Si}$ & 1.99 & 1.98 & 2.00 & 2.00 & 1.97 & 1.99 & 1.99 & 1.99 & 1.99 & 2.01 & 1.99 & 2.03 & 2.03 & 2.03 \\
\hline $\mathrm{Ti}$ & 0.00 & 0.00 & 0.00 & 0.00 & 0.00 & 0.00 & 0.00 & 0.00 & 0.00 & 0.00 & 0.00 & 0.00 & 0.00 & 0.00 \\
\hline $\mathrm{Al}$ & 0.59 & 0.57 & 0.62 & 0.62 & 0.61 & 0.28 & 0.27 & 0.28 & 0.29 & 0.05 & 0.00 & 0.37 & 0.35 & 0.36 \\
\hline $\mathrm{Cr}$ & 0.00 & 0.00 & 0.00 & 0.00 & 0.00 & 0.00 & 0.00 & 0.00 & 0.00 & 0.01 & 0.00 & 0.00 & 0.00 & 0.00 \\
\hline $\mathrm{Fe}^{3+}$ & 0.14 & 0.15 & 0.14 & 0.14 & 0.19 & 0.12 & 0.14 & 0.13 & 0.12 & 0.02 & 0.02 & 0.00 & 0.03 & 0.01 \\
\hline $\mathrm{Fe}^{2+}$ & 0.04 & 0.03 & 0.04 & 0.05 & 0.00 & 0.07 & 0.07 & 0.08 & 0.09 & 0.11 & 0.24 & 0.09 & 0.08 & 0.10 \\
\hline $\mathrm{Mn}$ & 0.00 & 0.00 & 0.00 & 0.00 & 0.00 & 0.00 & 0.00 & 0.00 & 0.00 & 0.00 & 0.00 & 0.00 & 0.00 & 0.00 \\
\hline $\mathrm{Mg}$ & 0.25 & 0.26 & 0.20 & 0.21 & 0.22 & 0.56 & 0.54 & 0.54 & 0.53 & 0.86 & 1.75 & 0.51 & 0.51 & 0.50 \\
\hline $\mathrm{Ca}$ & 0.28 & 0.31 & 0.22 & 0.23 & 0.27 & 0.61 & 0.59 & 0.58 & 0.58 & 0.82 & 0.00 & 0.57 & 0.56 & 0.56 \\
\hline $\mathrm{Na}$ & 0.71 & 0.69 & 0.73 & 0.73 & 0.75 & 0.38 & 0.40 & 0.40 & 0.40 & 0.11 & 0.00 & 0.42 & 0.44 & 0.43 \\
\hline K & 0.00 & 0.00 & 0.05 & 0.02 & 0.00 & 0.00 & 0.00 & 0.00 & 0.00 & 0.00 & 0.00 & 0.00 & 0.00 & 0.00 \\
\hline Total & 4.00 & 3.99 & 4.00 & 3.99 & 4.00 & 4.00 & 4.00 & 4.00 & 4.00 & 3.99 & 4.00 & 3.99 & 4.00 & 3.99 \\
\hline $\mathrm{Jd}$ & 0.59 & 0.57 & 0.66 & 0.65 & 0.61 & 0.28 & 0.28 & 0.29 & 0.29 & 0.05 & & 0.37 & 0.35 & 0.37 \\
\hline Ac & 0.14 & 0.15 & 0.15 & 0.14 & 0.19 & 0.12 & 0.14 & 0.13 & 0.12 & 0.02 & & 0.00 & 0.03 & 0.01 \\
\hline Di & 0.25 & 0.27 & 0.20 & 0.19 & 0.26 & 0.55 & 0.53 & 0.52 & 0.51 & 0.78 & & 0.49 & 0.49 & 0.47 \\
\hline Hed & 0.04 & 0.03 & 0.04 & 0.05 & 0 & 0.07 & 0.06 & 0.08 & 0.08 & 0.10 & & 0.08 & 0.08 & 0.09 \\
\hline
\end{tabular}


Table 4.3 (continued)

\begin{tabular}{|c|c|c|c|c|c|c|c|c|c|c|c|c|c|c|c|}
\hline \multirow{3}{*}{$\begin{array}{l}\text { Locality } \\
\text { sample } \\
\mathrm{Nr}\end{array}$} & \multicolumn{3}{|c|}{ Shuanghe } & \multicolumn{4}{|l|}{ Lidu } & \multicolumn{6}{|c|}{ Raobazhai } & \multicolumn{2}{|c|}{ Yanzihe } \\
\hline & DB31 & & & DB44 & & & & R14 & & & & & & & \\
\hline & 15 & 16 & 17 & 18 & 19 & 20 & 21 & 22 & 23 & 24 & 25 & 26 & 27 & 28 & 29 \\
\hline Mineral & $\begin{array}{l}\text { Cpx } \\
\text { (rim) }\end{array}$ & $\begin{array}{l}\text { Cpx } \\
\text { (center) }\end{array}$ & $\begin{array}{l}\text { Cpx } \\
\text { (core) }\end{array}$ & $C p x_{\text {in }}$ & $\begin{array}{l}\mathrm{Cpx} \\
\text { (rim) }\end{array}$ & $\begin{array}{l}\text { Cpx } \\
\text { (core) }\end{array}$ & $\begin{array}{l}\text { Cpx } \\
\text { (sym) }\end{array}$ & $\begin{array}{l}\text { Cpx } \\
\text { (core) }\end{array}$ & $\begin{array}{l}\text { Cpx } \\
\text { center }\end{array}$ & $\begin{array}{l}\mathrm{Cpx} \\
\text { (rim) }\end{array}$ & $\begin{array}{l}\mathrm{Cpx}_{\mathrm{in}} \\
\text { (core) }\end{array}$ & $\begin{array}{l}\mathrm{Cpx}_{\text {in }} \\
\text { (rim) }\end{array}$ & Opx & $\begin{array}{l}\text { Opx } \\
\text { (core) }\end{array}$ & $\begin{array}{l}\text { Opx } \\
\text { (rim) }\end{array}$ \\
\hline $\mathrm{SiO}_{2}$ & 58.75 & 58.71 & 58.74 & 55.91 & 57.46 & 56.88 & 54.44 & 54.51 & 53.40 & 50.75 & 53.19 & 53.19 & 53.49 & 49.47 & 49.35 \\
\hline $\mathrm{TiO}_{2}$ & 0.05 & 0.03 & 0.03 & 0.03 & 0.03 & 0.00 & 0.06 & 0.09 & 0.14 & 0.08 & 0.29 & 0.15 & 0.06 & 0.03 & 0.03 \\
\hline $\mathrm{Al}_{2} \mathrm{O}_{3}$ & 20.14 & 20.03 & 19.95 & 8.59 & 12.37 & 11.87 & 3.45 & 7.06 & 5.88 & 6.38 & 6.43 & 6.70 & 2.33 & 0.71 & 0.72 \\
\hline $\mathrm{Cr}_{2} \mathrm{O}_{3}$ & 0.03 & 0.00 & 0.01 & 0.05 & 0.00 & 0.00 & 0.00 & 0.09 & 0.08 & 0.11 & 0.07 & 0.05 & 0.08 & 0.00 & 0.00 \\
\hline $\mathrm{FeO}$ & 3.57 & 3.63 & 3.59 & 7.96 & 4.65 & 7.03 & 9.89 & 5.03 & 7.02 & 7.34 & 4.75 & 5.24 & 19.86 & 39.35 & 39.15 \\
\hline $\mathrm{MnO}$ & 0.02 & 0.02 & 0.01 & 0.01 & 0.00 & 0.07 & 0.01 & 0.01 & 0.10 & 0.13 & 0.03 & 0.04 & 0.22 & 1.22 & 1.17 \\
\hline $\mathrm{MgO}$ & 2.15 & 2.18 & 2.21 & 7.86 & 6.97 & 6.28 & 10.56 & 11.83 & 12.18 & 12.89 & 12.28 & 12.35 & 24.39 & 10.03 & 9.94 \\
\hline $\mathrm{CaO}$ & 3.13 & 3.20 & 3.15 & 12.71 & 10.65 & 8.89 & 16.51 & 18.11 & 19.63 & 20.94 & 18.64 & 18.45 & 0.46 & 1.07 & 1.24 \\
\hline $\mathrm{Na}_{2} \mathrm{O}$ & 13.29 & 13.37 & 13.45 & 7.79 & 8.01 & 9.45 & 4.93 & 3.90 & 1.76 & 1.37 & 3.40 & 3.48 & 0.02 & 0.00 & 0.01 \\
\hline $\mathrm{K}_{2} \mathrm{O}$ & 0.01 & 0.00 & 0.01 & 0.03 & 0.00 & 0.05 & 0.15 & 0.00 & 0.02 & 0.01 & 0.00 & 0.01 & 0.01 & 0.02 & 0.01 \\
\hline Total & 101.15 & 101.17 & 101.15 & 100.94 & 100.14 & 100.52 & 100.00 & 100.63 & 100.20 & 99.99 & 99.07 & 99.67 & 100.92 & 101.91 & 101.61 \\
\hline $\mathrm{Si}$ & 1.99 & 1.99 & 1.99 & 1.98 & 2.03 & 1.99 & 1.98 & 1.95 & 1.96 & 1.86 & 1.94 & 1.92 & 1.94 & 1.97 & 1.97 \\
\hline $\mathrm{Ti}$ & 0.00 & 0.00 & 0.00 & 0.00 & 0.00 & 0.00 & 0.00 & 0.00 & 0.00 & 0.00 & 0.01 & 0.00 & 0.00 & 0.00 & 0.00 \\
\hline $\mathrm{Al}$ & 0.81 & 0.80 & 0.80 & 0.36 & 0.51 & 0.49 & 0.15 & 0.30 & 0.25 & 0.28 & 0.28 & 0.29 & 0.10 & 0.03 & 0.03 \\
\hline $\mathrm{Cr}$ & 0.00 & 0.00 & 0.00 & 0.00 & 0.00 & 0.00 & 0.00 & 0.00 & 0.00 & 0.00 & 0.00 & 0.00 & 0.00 & 0.00 & 0.00 \\
\hline $\mathrm{Fe}^{3+}$ & 0.08 & 0.10 & 0.10 & 0.22 & 0.00 & 0.16 & 0.24 & 0.06 & 0.00 & 0.09 & 0.07 & 0.10 & 0.01 & 0.02 & 0.02 \\
\hline $\mathrm{Fe}^{2+}$ & 0.02 & 0.01 & 0.00 & 0.01 & 0.14 & 0.04 & 0.06 & 0.09 & 0.22 & 0.14 & 0.07 & 0.06 & 0.60 & 1.29 & 1.29 \\
\hline $\mathrm{Mn}$ & 0.00 & 0.00 & 0.00 & 0.00 & 0.00 & 0.00 & 0.00 & 0.00 & 0.00 & 0.00 & 0.00 & 0.00 & 0.01 & 0.04 & 0.04 \\
\hline $\mathrm{Mg}$ & 0.11 & 0.11 & 0.11 & 0.41 & 0.37 & 0.33 & 0.57 & 0.63 & 0.67 & 0.71 & 0.67 & 0.67 & 1.32 & 0.60 & 0.59 \\
\hline $\mathrm{Ca}$ & 0.11 & 0.12 & 0.11 & 0.48 & 0.40 & 0.33 & 0.64 & 0.69 & 0.77 & 0.82 & 0.73 & 0.71 & 0.02 & 0.05 & 0.05 \\
\hline $\mathrm{Na}$ & 0.87 & 0.88 & 0.88 & 0.53 & 0.55 & 0.64 & 0.35 & 0.27 & 0.13 & 0.10 & 0.24 & 0.24 & 0.00 & 0.00 & 0.00 \\
\hline K & 0.00 & 0.00 & 0.00 & 0.00 & 0.00 & 0.00 & 0.01 & 0.00 & 0.00 & 0.00 & 0.00 & 0.00 & 0.00 & 0.00 & 0.00 \\
\hline Total & 3.99 & 4.01 & 3.99 & 3.99 & 4.00 & 3.98 & 4.01 & 4.00 & 4.00 & 4.00 & 4.01 & 3.99 & 4.00 & 4.00 & 4.00 \\
\hline $\mathrm{Jd}$ & 0.82 & 0.80 & 0.80 & 0.35 & 0.54 & 0.50 & 0.15 & 0.31 & 0.13 & 0.01 & 0.29 & 0.28 & & & \\
\hline Ac & 0.08 & 0.10 & 0.10 & 0.22 & 0.00 & 0.17 & 0.25 & 0.07 & 0.00 & 0.10 & 0.08 & 0.09 & & & \\
\hline Di & 0.09 & 0.11 & 0.12 & 0.46 & 0.31 & 0.30 & 0.59 & 0.53 & 0.65 & 0.75 & 0.58 & 0.57 & & & \\
\hline Hed & 0.02 & 0.01 & 0.00 & 0.01 & 0.12 & 0.04 & 0.06 & 0.09 & 0.21 & 0.15 & 0.07 & 0.06 & & & \\
\hline
\end{tabular}


Table 4.4. Representative microprobe analyses of amphibole and other phases (Am, amphibole; Phen, phengite, Ky kyanite; Ol, olivine; in, inclusions)

\begin{tabular}{|c|c|c|c|c|c|c|c|c|c|c|c|c|c|c|c|}
\hline Locality & Bixiling & & & & & & & Shuang & & Lidu & & & & & \\
\hline $\begin{array}{l}\text { Sample } \\
\mathrm{Nr}\end{array}$ & DB02 & & & & DB07 & & DB10 & DB31 & & & & & & & \\
\hline Mineral & $\underset{\text { (mat rix) }}{\mathrm{Am}}$ & $\begin{array}{l}\text { Am } \\
\text { (in) }\end{array}$ & $\begin{array}{l}\text { Phen } \\
\text { (core) }\end{array}$ & $\begin{array}{l}\text { Phen } \\
\text { (rim) }\end{array}$ & $\mathrm{Ky}$ & $\mathrm{Am}$ & $\mathrm{Ol}$ & $\mathrm{Am}$ & $\mathrm{Am}$ & $\begin{array}{l}\text { Am } \\
\text { (in) }\end{array}$ & $\begin{array}{l}\text { Am } \\
\text { (in) }\end{array}$ & $\underset{\text { (matrix) }}{\mathrm{Am}}$ & Phen & talc & corudite \\
\hline $\mathrm{SiO}_{2}$ & 48.32 & 43.34 & 53.39 & 51.85 & 37.45 & 40.57 & 39.73 & 40.98 & 41.07 & 43.46 & 41.79 & 51.49 & 50.97 & 62.38 & 1.46 \\
\hline $\mathrm{TiO}_{2}$ & 0.17 & 0.21 & 0.31 & 0.32 & 0.01 & 0.76 & 0.04 & 0.04 & 0.04 & 0.13 & 0.06 & 0.05 & 0.22 & 0.01 & 0.01 \\
\hline $\mathrm{Al}_{2} \mathrm{O}_{3}$ & 9.58 & 12.81 & 21.84 & 23.75 & 62.18 & 18.21 & 0.02 & 20.33 & 20.40 & 15.67 & 16.00 & 7.84 & 26.42 & 0.04 & 96.09 \\
\hline $\mathrm{Cr}_{2} \mathrm{O}_{3}$ & 0.04 & 0.00 & 0.00 & 0.02 & 0.10 & 0.00 & 0.03 & 0.00 & 0.02 & 0.00 & 0.04 & 0.02 & 0.00 & 0.00 & 0.07 \\
\hline $\mathrm{FeO}$ & 12.25 & 15.24 & 2.82 & 3.29 & 0.30 & 16.29 & 13.81 & 15.18 & 15.40 & 15.50 & 12.97 & 7.82 & 1.65 & 2.51 & 0.40 \\
\hline $\mathrm{MnO}$ & 0.17 & 0.16 & 0.00 & 0.06 & 0.02 & 0.08 & 0.08 & 0.41 & 0.37 & 0.01 & 0.10 & 0.11 & 0.05 & 0.02 & 0.00 \\
\hline $\mathrm{MgO}$ & 13.68 & 10.17 & 4.79 & 3.98 & 0.01 & 7.43 & 46.39 & 7.38 & 7.49 & 9.76 & 11.93 & 17.97 & 3.98 & 29.78 & 0.01 \\
\hline $\mathrm{CaO}$ & 10.21 & 10.82 & 0.01 & 0.01 & 0.00 . & 7.59 & 0.00 & 5.29 & 5.24 & 7.00 & 10.15 & 6.05 & 0.01 & 0.03 & 0.01 \\
\hline $\mathrm{Na}_{2} \mathrm{O}$ & 3.30 & 4.13 & 0.16 & 0.63 & 0.00 & 5.39 & 0.00 & 7.49 & 7.56 & 6.06 & 4.39 & 4.99 & 0.80 & 0.18 & 0.28 \\
\hline $\mathrm{K}_{2} \mathrm{O}$ & 0.20 & 1.03 & 10.75 & 10.08 & 0.00 & 0.84 & 0.02 & 0.37 & 0.38 & 0.13 & 0.49 & 0.09 & 9.64 & 0.00 & 0.03 \\
\hline $\mathrm{Cl}$ & 0.00 & 0.02 & 0.00 & 0.00 & & 0.07 & & 0.00 & 0.00 & 0.00 & 0.00 & 0.01 & & & \\
\hline Total & 97.92 & 97.93 & 94.07 & 93.99 & 100.07 & 97.23 & 100.12 & 97.46 & 97.97 & 97.72 & 97.92 & 96.44 & 93.73 & 94.94 & 98.37 \\
\hline $\mathrm{Si}$ & 6.94 & 6.50 & 3.61 & 3.50 & 1.01 & 6.04 & 0.99 & 5.99 & 5.97 & 6.31 & 6.07 & 7.11 & 3.41 & 3.43 & \\
\hline $\mathrm{Ti}$ & 0.02 & 0.02 & 0.01 & 0.02 & 0.00 & 0.09 & 0.00 & 0.00 & 0.00 & 0.01 & 0.01 & 0.01 & 0.01 & 0.00 & \\
\hline $\mathrm{Al}$ & 1.62 & 2.27 & 1.74 & 1.89 & 1.98 & 3.19 & 0.00 & 3.50 & 3.49 & 2.68 & 2.74 & 1.28 & 2.08 & 0.00 & \\
\hline $\mathrm{Cr}$ & 0.00 & 0.00 & 0.00 & 0.00 & 0.00 & 0.00 & 0.00 & 0.00 & 0.00 & 0.00 & 0.00 & 0.00 & 0.00 & 0.00 & \\
\hline $\mathrm{Fe}^{3+}$ & 0.36 & 0.00 & 0.07 & 0.12 & 0.01 & 0.43 & 0.00 & 0.67 & 0.73 & 0.76 & 0.60 & 0.90 & 0.09 & 0.12 & \\
\hline $\mathrm{Fe}^{2+}$ & 1.11 & 1.91 & 0.09 & 0.07 & 0.00 & 1.60 & 0.29 & 1.18 & 1.14 & 1.12 & 0.97 & 0.00 & 0.00 & 0.00 & \\
\hline $\mathrm{Mn}$ & 0.02 & 0.02 & 0.00 & 0.00 & 0.00 & 0.01 & 0.00 & 0.05 & 0.05 & 0.00 & 0.01 & 0.01 & 0.00 & 0.00 & \\
\hline $\mathrm{Mg}$ & 2.93 & 2.28 & 0.48 & 0.40 & 0.00 & 1.65 & 1.72 & 1.61 & 1.62 & 2.11 & 2.59 & 3.70 & 0.40 & 2.44 & \\
\hline $\mathrm{Ca}$ & 1.57 & 1.74 & 0.00 & 0.00 & 0.00 & 1.21 & 0.00 & 0.83 & 0.82 & 1.09 & 1.58 & 0.89 & 0.00 & 0.00 & \\
\hline $\mathrm{Na}$ & 0.92 & 1.20 & 0.02 & 0.08 & 0.00 & 1.55 & 0.00 & 2.12 & 2.13 & 1.71 & 1.24 & 1.34 & 0.10 & 0.02 & \\
\hline $\mathrm{K}$ & 0.04 & 0.20 & 0.93 & 0.87 & 0.00 & 0.16 & 0.00 & 0.07 & 0.07 & 0.02 & 0.09 & 0.02 & 0.82 & 0.00 & \\
\hline $\mathrm{Cl}$ & 0.00 & 0.00 & 0.00 & 0.00 & & 0.02 & & 0.00 & 0.00 & 0.00 & 0.00 & 0.00 & & & \\
\hline
\end{tabular}


Table 4.4. (continued)

\begin{tabular}{|c|c|c|c|c|c|c|c|c|c|c|}
\hline \multirow{3}{*}{$\begin{array}{l}\text { Locality } \\
\text { Sample } \\
\mathrm{Nr}\end{array}$} & \multicolumn{5}{|c|}{ Raobazhai } & \multicolumn{5}{|l|}{ Yanzihe } \\
\hline & \multirow{2}{*}{\multicolumn{10}{|c|}{ R14 }} \\
\hline & & & & & & & & & & \\
\hline Mineral & $\underset{\text { (matrix) }}{\mathrm{Am}}$ & $\underset{\text { (matrix) }}{\mathrm{Am}}$ & $\begin{array}{l}\mathrm{Am} \\
\text { (in) }\end{array}$ & $\begin{array}{c}\text { Pl } \\
\text { (matrix) }\end{array}$ & $\begin{array}{l}\mathrm{Pl} \\
\text { (in) }\end{array}$ & $\begin{array}{l}\text { Am } \\
\text { (vein) }\end{array}$ & $\begin{array}{l}\text { Am } \\
\text { (vein) }\end{array}$ & $\underset{\text { (matrix) }}{\mathrm{Am}}$ & $\begin{array}{c}\text { Am } \\
\text { matrix) }\end{array}$ & $\underset{\text { (matrix) }}{\mathrm{Am}}$ \\
\hline $\mathrm{SiO}_{2}$ & 41.43 & 41.06 & 41.81 & 60.72 & 61.04 & 38.12 & 38.64 & 37.46 & 37.41 & 47.37 \\
\hline $\mathrm{TiO}_{2}$ & 3.06 & 3.40 & 3.43 & 0.05 & 0.01 & 0.12 & 0.18 & 0.47 & 0.42 & 0.07 \\
\hline $\mathrm{AbO}_{3}$ & 13.97 & 13.23 & 13.00 & 23.41 & 23.40 & 12.17 & 11.88 & 12.59 & 12.76 & 6.20 \\
\hline $\mathrm{Cr}_{2} \mathrm{O}_{3}$ & 0.08 & 0.10 & 0.09 & 0.00 & 0.00 & 0.01 & 0.00 & 0.00 & 0.00 & 0.00 \\
\hline $\mathrm{FeO}$ & 11.85 & 11.69 & 11.98 & 0.20 & 0.30 & 25.91 & 25.93 & 27.20 & 26.83 & 22.02 \\
\hline $\mathrm{MnO}$ & 0.10 & 0.10 & 0.09 & 0.00 & 0.02 & 0.39 & 0.48 & 0.25 & 0.24 & 0.29 \\
\hline $\mathrm{MgO}$ & 12.60 & 12.60 & 12.84 & 0.01 & 0.03 & 5.00 & 5.33 & 3.84 & 3.83 & 9.36 \\
\hline $\mathrm{CaO}$ & 11.26 & 11.24 & 11.15 & 6.49 & 5.97 & 11.09 & 11.04 & 11.22 & 11.22 & 11.35 \\
\hline $\mathrm{Na}_{2} \mathrm{O}$ & 3.51 & 3.55 & 3.49 & 8.37 & 8.67 & 1.08 & 1.07 & 0.80 & 0.76 & 0.54 \\
\hline $\mathrm{K}_{2} \mathrm{O}$ & 0.04 & 0.05 & 0.05 & 0.03 & 0.02 & 2.70 & 2.52 & 3.07 & 3.11 & 0.59 \\
\hline $\mathrm{Cl}$ & 0.41 & 0.39 & 0.00 & 0.00 & 0.00 & 2.89 & 2.21 & 3.46 & 3.41 & 0.48 \\
\hline Total & 98.31 & 97.41 & & 99.28 & 99.45 & 99.49 & 99.28 & 100.60 & 100.24 & 98.32 \\
\hline $\mathrm{Si}$ & 6.05 & 6.07 & 6.11 & 2.72 & 2.72 & 6.04 & 6.07 & 5.97 & 5.98 & 7.05 \\
\hline $\mathrm{Ti}$ & 0.34 & 0.38 & 0.38 & 0.00 & 0.00 & 0.01 & 0.02 & 0.06 & 0.05 & 0.01 \\
\hline $\mathrm{Al}$ & 2.40 & 2.31 & 2.24 & 1.23 & 1.23 & 2.27 & 2.20 & 2.37 & 2.40 & 1.09 \\
\hline $\mathrm{Cr}$ & 0.01 & 0.01 & 0.01 & 0.00 & 0.00 & 0.00 & 0.00 & 0.00 & 0.00 & 0.00 \\
\hline $\mathrm{Fe}^{3+}$ & 0.29 & 0.19 & 0.30 & 0.01 & 0.01 & 0.96 & 1.08 & 0.93 & 0.88 & 0.93 \\
\hline $\mathrm{Fe}^{2+}$ & 1.16 & 1.25 & 1.17 & 0.00 & 0.00 & 2.47 & 2.32 & 2.70 & $\begin{array}{l}0.00 \\
2.71\end{array}$ & 1.81 \\
\hline $\mathrm{Mn}$ & 0.01 & 0.01 & 0.01 & 0.00 & 0.00 & 0.05 & 0.06 & 0.03 & 0.03 & 0.04 \\
\hline $\mathrm{Mg}$ & 2.74 & 2.78 & 2.80 & 0.00 & 0.00 & 1.18 & 1.25 & 0.91 & 0.91 & 2.08 \\
\hline $\mathrm{Ca}$ & 1.76 & 1.78 & 1.74 & 0.31 & 0.31 & 1.88 & 1.86 & 1.92 & 1.92 & 1.81 \\
\hline $\mathrm{Na}$ & 0.99 & 1.02 & 0.99 & 0.73 & 0.73 & 0.33 & 0.33 & 0.25 & 0.24 & 0.16 \\
\hline $\mathrm{K}$ & 0.01 & 0.01 & 0.01 & 0.00 & 0.00 & 0.55 & 0.50 & 0.62 & 0.63 & 0.11 \\
\hline $\mathrm{Cl}$ & 0.10 & 0.10 & 0.00 & & & 0.78 & 0.59 & 0.94 & 0.92 & 0.12 \\
\hline
\end{tabular}


and pyroxene from the Raobazhai eclogite, whereas those in Bixiling, Shima, Shuanghe and Yanzihe are homogeneous.

\subsubsection{Garnets in the Lidu eclogite}

Garnets from the Lidu eclogite exhibit very complicated chemical zoning patterns. Figure 4.7 shows a core-rim compositional profile for a $9 \mathrm{~mm}$ garnet grain in the eclogite from Lidu (the position of the profile is shown in Fig. 7.4). In general, the zoning pattern is characterized by increasing $X_{\operatorname{Prp}}$ and decreasing $X_{\mathrm{Grs}}$ and $\mathrm{X}_{\mathrm{Alm}}$ outward from the core to the rim of the garnet. The spessartine content almost does not change and is as low as 0.1 to $0.5 \mathrm{~mol} \%$ from the core to the rim. Backscattered-electron image of the garnets indicates that these zonations are nearly symmetrical (Fig. 4.8).

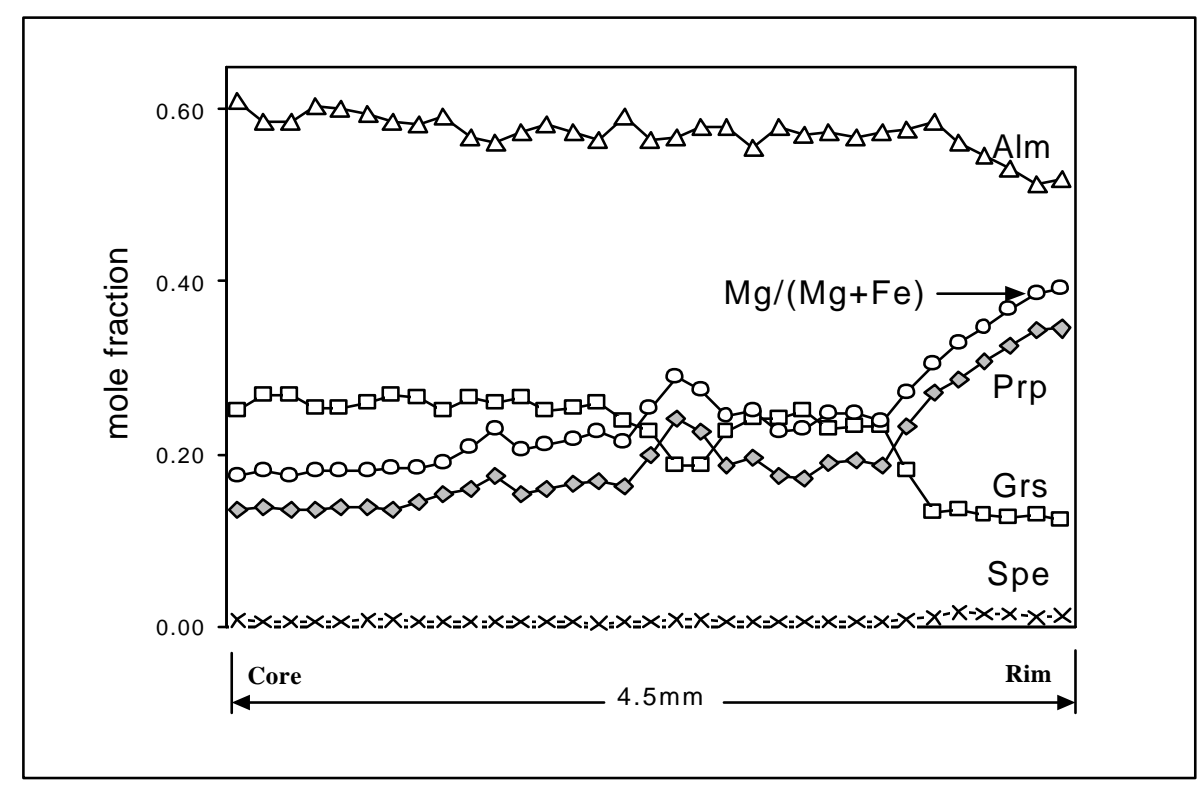

Fig. 4.7. Compositional profile of a garnet in the eclogite from Lidu.

As shown in Fig. 4.8, the two garnets from the Lidu eclogites have quite different compositional zoning patterns. In the left garnet an old core and a younger rim are observed, indicating at least two stages of garnet growth for the eclogite from Lidu. However, the right garnet shows a quite different pattern: the central portion of the garnet (black part of the photo) has been totally replaced by hydroxyl-bearing minerals, such as phengite and amphibole; although the core of the porphyroblast is still garnet, it has different compositions compared to the original core which is partly preserved in the porphyroblast (the light parts). 

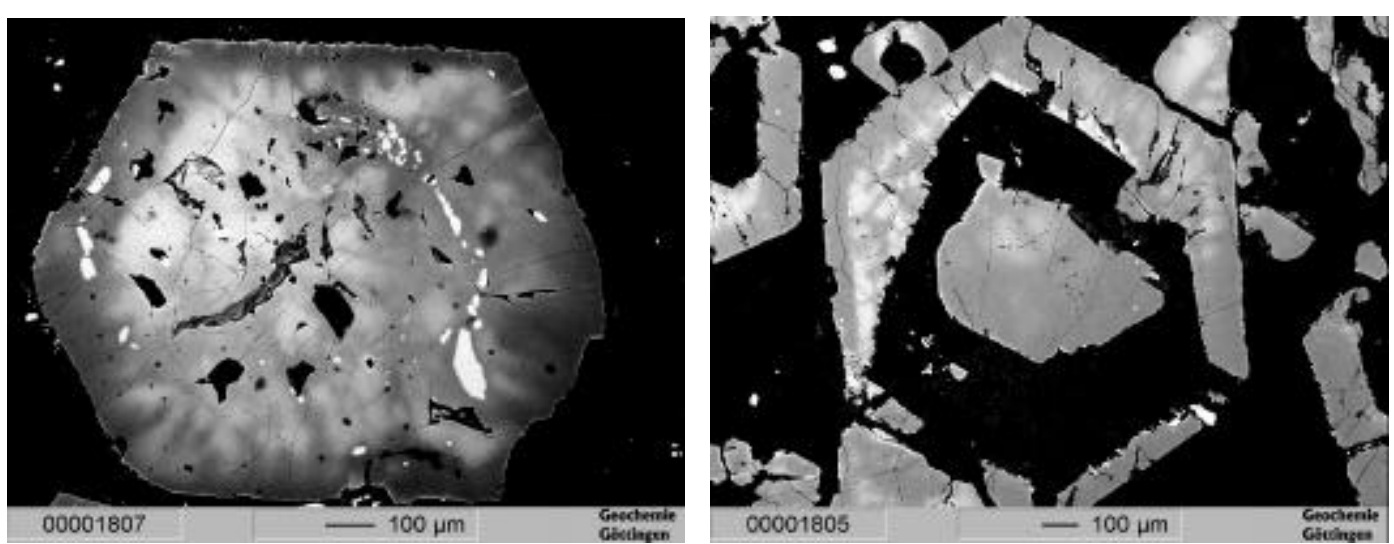

Fig. 4.8. Backscattered-electron images of two garnets in the eclogite from Lidu. Different luminosities reflect different major element contents of garnets. Compositional zonations are nearly symmetrical. Note that the luminosity in the core of the left garnet is different from that of the right garnet, which has similar luminosities in the core and the margin. The total dark mantle of the right garnet represents hydroxyl-bearing minerals.

Semi-quantitative microprobe mapping displays different zoning patterns for the two kinds of garnets. $\mathrm{MgO}, \mathrm{CaO}, \mathrm{FeO}$ and $\mathrm{MnO}$ maps of the left garnet in Fig. 4.8 indicate that the core and the rim of this garnet formed at different stages of garnet growth (Fig. 4.9a): Mg shows a distinct increase in concentrations towards the rim of the crystal whereas Fe decreases towards the rim; $\mathrm{Mn}$ is particularly interesting because it shows a hump in the center of the crystal, a steady decrease towards the rim and then a rise just at the rim; variations of $\mathrm{Ca}$ in the left side are very pronounced whereas in the right side they are irregular, which probably indicate disturbances from fluids during garnet growth. In contrast, microprobe mapping for a twingarnet in the same section shows a totally different compositional pattern: the rim and the core have similar $\mathrm{MgO}$ and $\mathrm{MnO}$ contents, being clearly higher than the relics of the original central portion; this indicates that cores of some garnets were replaced by late formed garnets; furthermore, the presence of hydroxyl-bearing minerals in the central portion of the garnet crystal suggests a decompression and a rock-fluid interaction during garnet growth. 
A

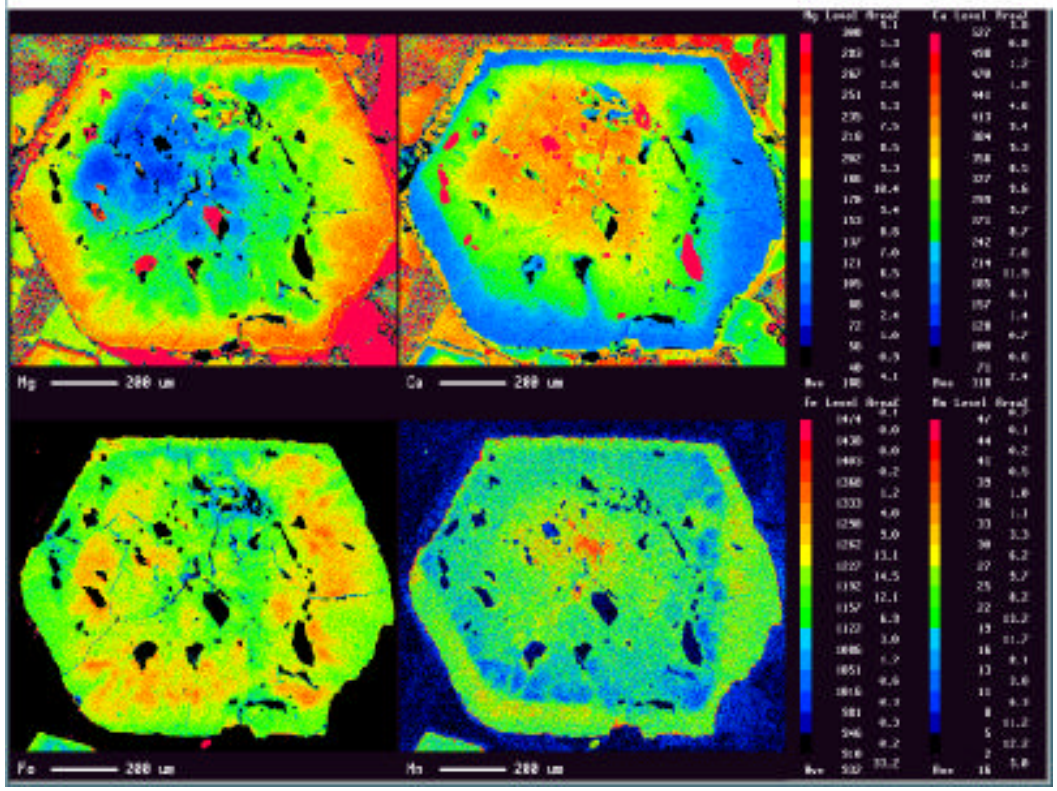

B

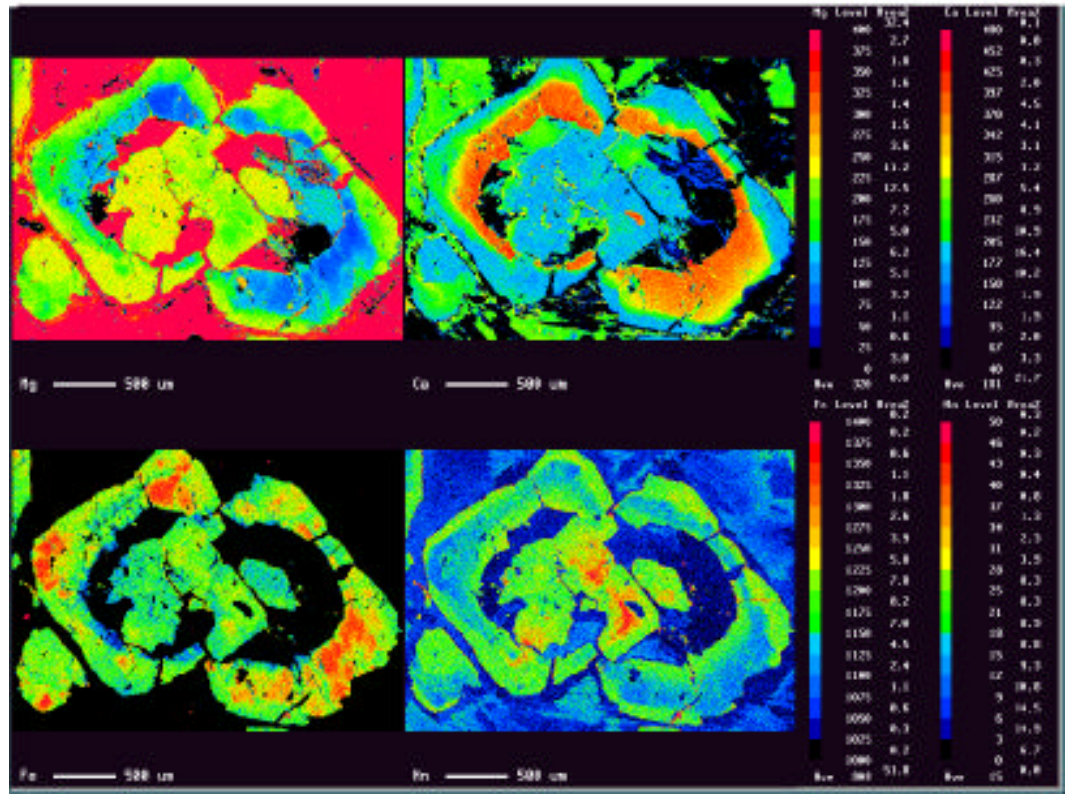

Fig. 4.9. Compositional mapping of garnets in the Lidu eclogite. A: garnet porphyroblast exhibits higher $\mathrm{Ca}$ and lower $\mathrm{Mg}$ contents in the core than in the rim; variations of $\mathrm{Ca}$ in the left side are very sharp, whereas in the right side are irregular, which probably indicate disturbances from fluids. B: twin-garnet has similar compositions in the core and rim. 


\subsubsection{Garnet in the Raobazhai eclogite}

In comparison to garnets from Lidu eclogite, garnets from Raobazhai display less zoning.

Meanwhile, their pyrope and almandine contents are quite different from those of Lidu.

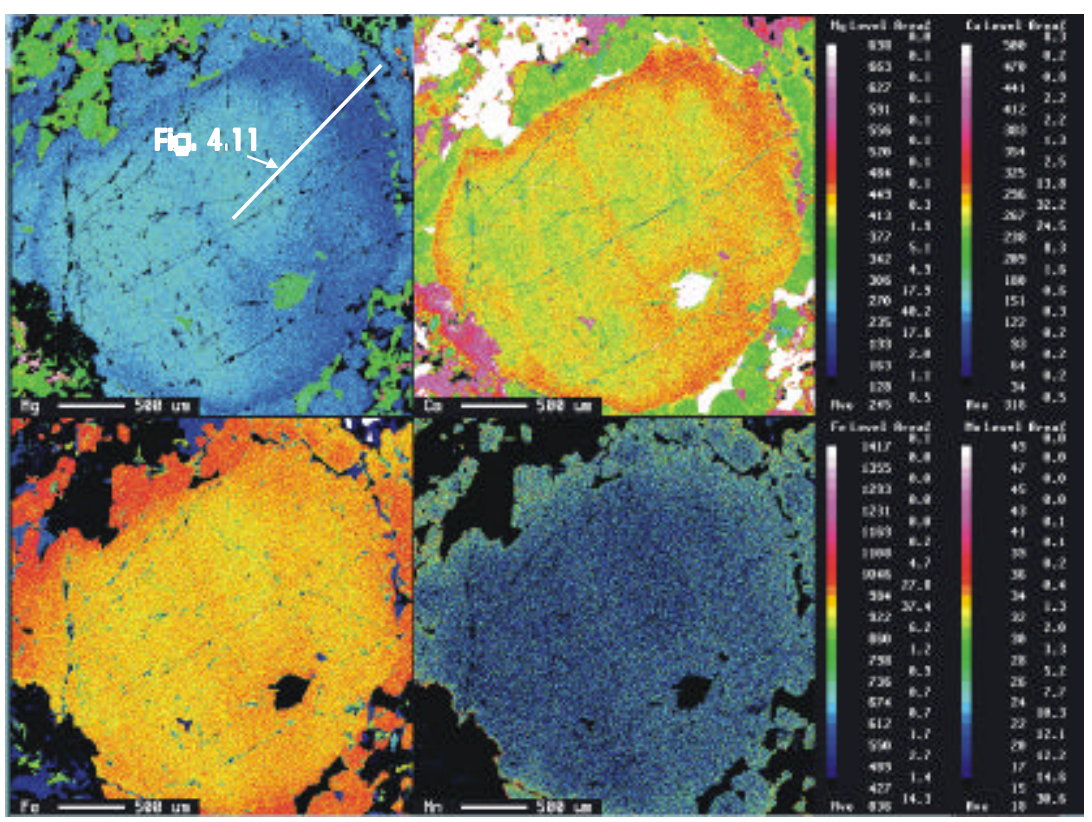

Fig. 4.10. Semi-quantitative mapping of a garnet porphyroblast from Raobazhai

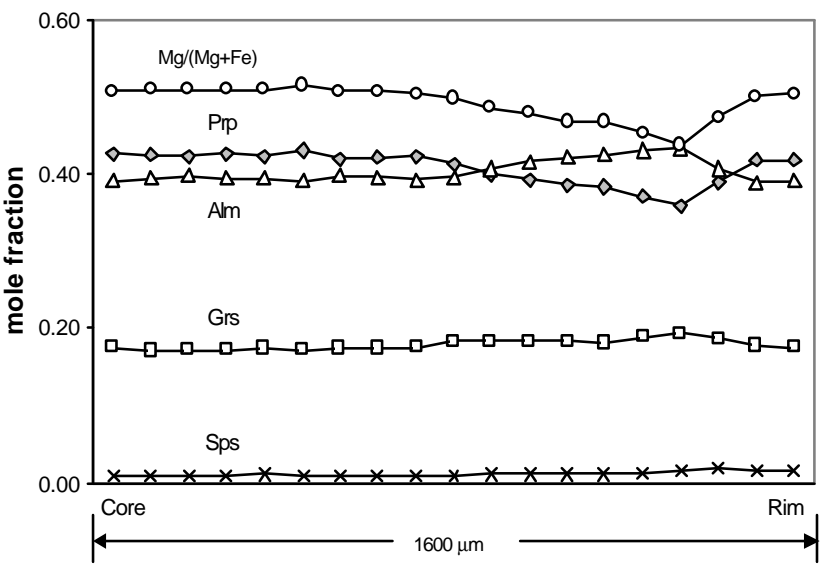

Fig. 4.11. Garnet compositional zoning profile (Core-rim, about $1.6 \mathrm{~mm}$ in length). Profile of probe analysis is along the white line in Fig. 4.10 
Some large garnet crystals $(>2 \mathrm{~mm}$ in size) show systematic, but much weaker chemical zonations, whereas small garnets are generally homogeneous, having a composition equivalent to the rim of the large garnet. Semi-quantitative mapping of a 3mm-wide garnet porphyroblast demonstrates zoning in $\mathrm{Mg}, \mathrm{Ca}, \mathrm{Fe}$ (Fig. 4.10). A profile of this garnet (along the white line of Fig. 4.10) is shown in Fig. 4.11. Two zones can be identified: an inner zone where $\mathrm{Mg}$ decreases and $\mathrm{Ca}$ slightly increases from the core outwards, whereas Fe and Mn are almost constant; and an outer zone with an increase in $\mathrm{Mg}, \mathrm{Fe}, \mathrm{Mn}$ and a decrease in $\mathrm{Ca}$.

\subsubsection{Zoned clinopyroxene in Raobazhai}

Most matrix pyroxenes are strongly zoned. One example is shown in Fig. 4.12 (see also Table 4.3). In a $\mathrm{QJ}$ classification diagram (Fig 4.12a), where $\mathrm{Q}=\mathrm{Ca}+\mathrm{Mg}+\mathrm{Fe}^{2+}$ and $\mathrm{J}=2 \mathrm{Na}$ (Morimoto et el., 1998), profiles of pyroxene grains show that the cores belong to Ca-Na group, whereas the margins fall into the $\mathrm{Ca}-\mathrm{Mg}-\mathrm{Fe}$ (Quad) area. In classification dagrams of the $\mathrm{Ca}-\mathrm{Na}$ and $\mathrm{Ca}-\mathrm{Mg}$-Fe groups (Fig.4.12b, c), there are large compositional variations from omphacite through diopside to augite, which result from a decrease of jadeite content from core to rim (from c. 30 to c. 7\%). Additionally, a minor secondary phase enstatite (hypersthene) occurs at the very margin of the grain.

Semi-quantitative mapping of pyroxene crystals clearly demonstrates compositional zoning as shown in Fig. 4.13a, b. From core to rim there is a decrease in Na with an increase in $\mathrm{Ca}, \mathrm{Mg}$ and total $\mathrm{Fe}$. It is important to note that the central portions of most pyroxene grains have 
A $\mathbf{Q}\left(\mathbf{C} \mathbf{a}+\mathbf{M g} \mathbf{g}+\mathbf{F e}^{2+}\right)$

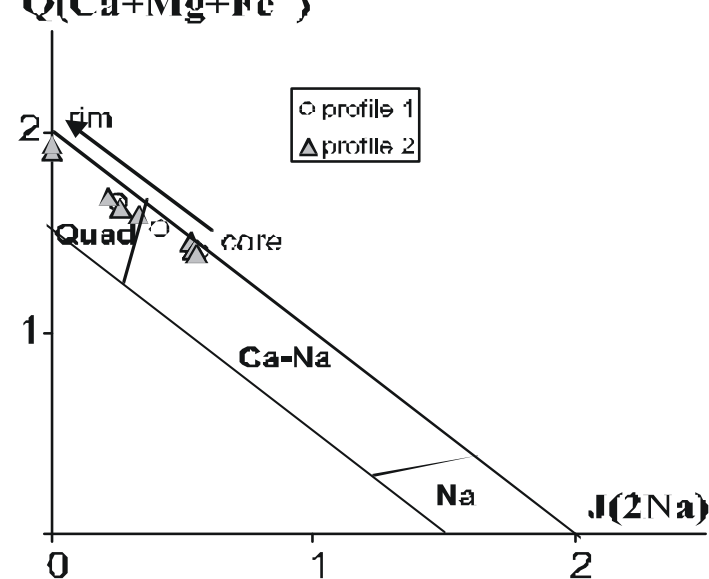

B

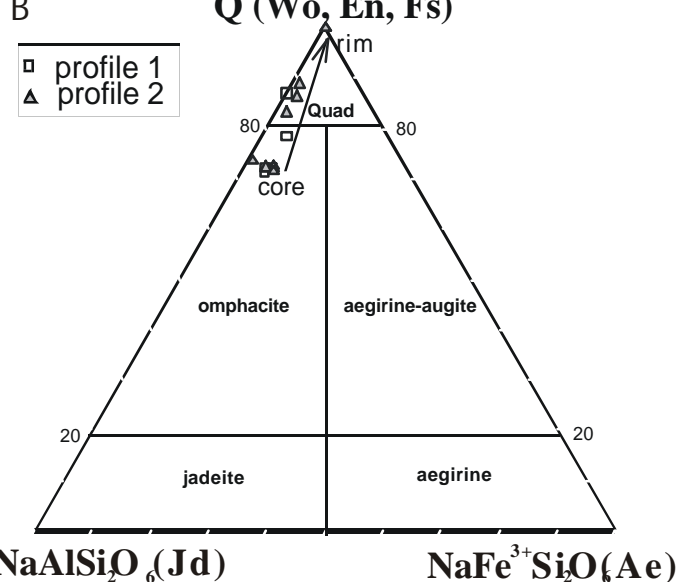

C CaSiO (Wo)

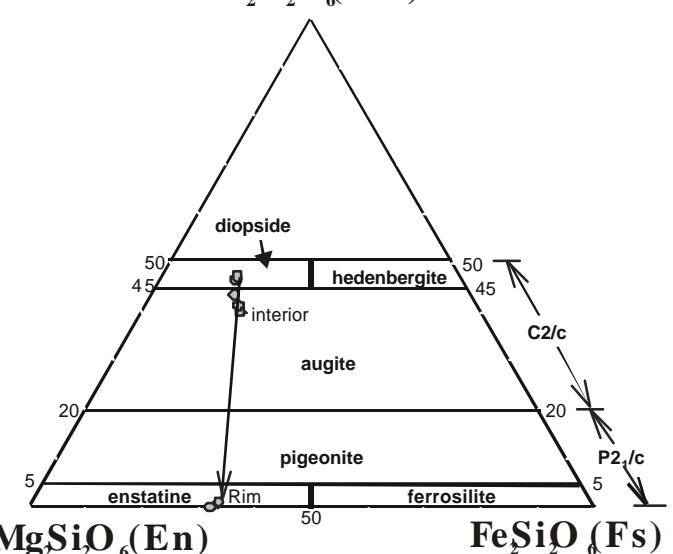

Fig. 4.12 Classification diagrams for pyroxene in Raobazhai (after Morimoto et al., 1988); Quad represents the CaMg-Fe pyroxene area 
A
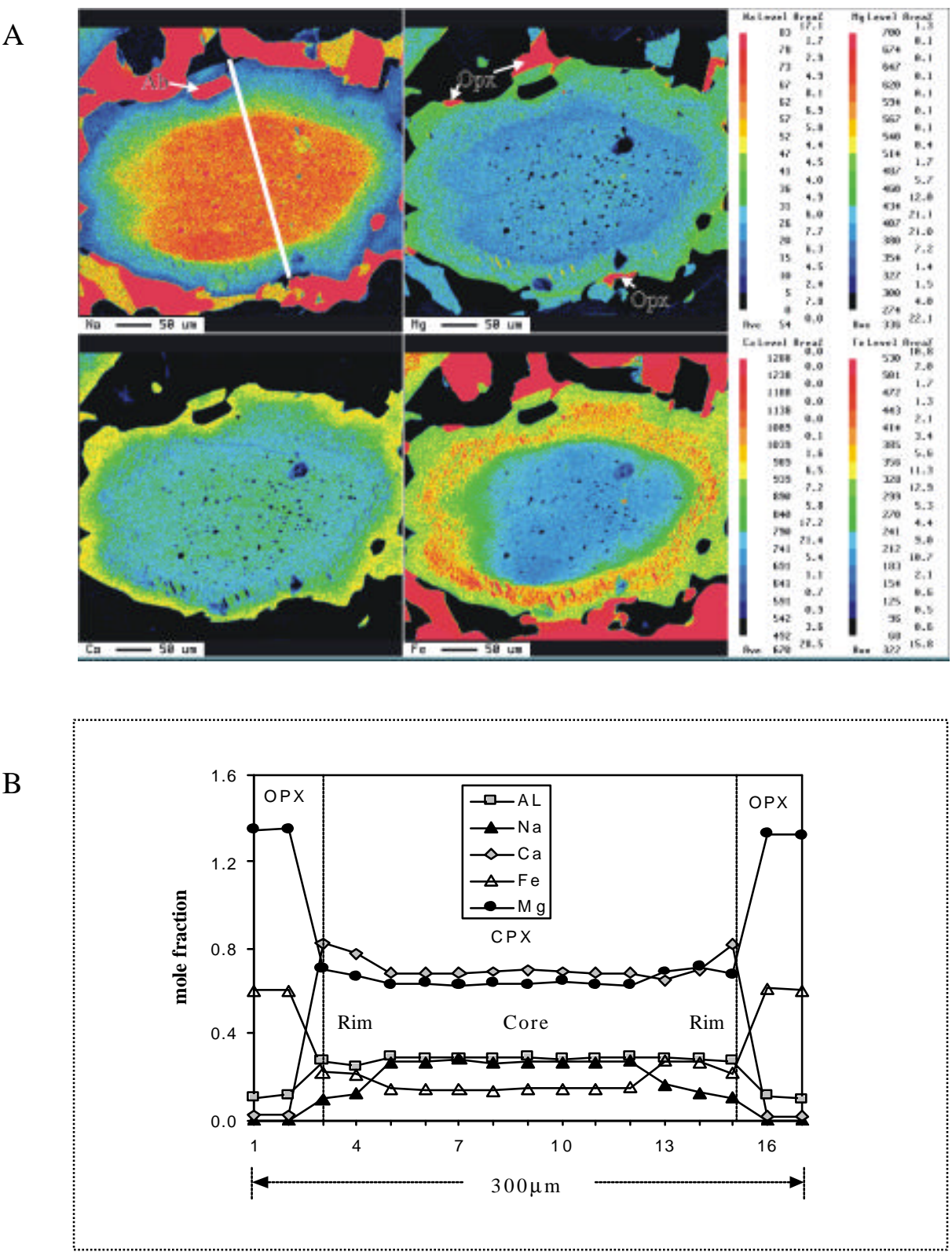

Fig.4.13. A Semiquantitative mapping of a pyroxene grain in the Raobazhai eclogite. The maps show clearly compositional zones of $\mathrm{Na}, \mathrm{Mg}, \mathrm{Ca}$ and Fe from the core to the rim (see text for detailed description); at the very margin small overgrowth orthopyroxenes can be observed. B Pyroxene compositional zoning profile (rim-rim). Location of probe analysis is along the white line in A.

a sieve-mesh-texture with albite inclusions. This texture was interpreted to result from the decomposition of a jadeite-rich clinopyroxene to a jadeite-poor clinopyroxene + feldspar (e.g., Carswell, 1975). Thus, the cores of pyroxene might have had higher jadeite contents during peak metamorphic conditions than actually observed. Pyroxene inclusions in gamet are homogeneous in composition, but all of these inclusions contain some exsolved rutile, which is in accordance with the high Ti-content of the whole rock. 


\subsection{Indicators of peak metamorphic conditions for UHP metamorphism}

Coesite inclusions in metamorphic rocks from the SDT demonstrate that these rocks have suffered peak metamorphic pressures > 28 kbar (Okay et al., 1989; Wang et al., 1989). The discovery of diamond inclusions in garnet of eclogites in the SDT by $\mathrm{Xu}$ et al. (1992) indicates a metamorphic pressure $>40$ kbar. However, since these polymorphic phase relations indicate only a minimum pressure, the peak metamorphic pressure of the UHP metamorphism in the DabieSulu area might be even higher.

High concentrations of potassium $(>1 \mathrm{wt} \%)$ in clinopyroxene inclusions from diamonds (Harlow and Veblen 1991) contradicts with the traditional view of pyroxene crystal chemistry, which states that $\mathrm{K}$ is too large to be incorporated in the pyroxene structure, and implies that clinopyroxene can be a significant host for $\mathrm{K}$ in the mantle. Furthermore, potassium solubility in clinopyroxene and sodium solubility in garnet have been empirically confirmed to be pressure indicators for the UHP metamorphic rocks from the Kokchetav Massif (Chopin and Sobolev 1995). In contrast to coarse-grained garnet and omphacite, which were probably formed during recrystallization (early uplift) of the UHP eclogites, omphacite inclusions in garnet were probably formed during prograde eclogite-facies metamorphism, and might be subjected to peak metamorphic conditions along with coesite and micro-diamond (if any). The fact that omphacite inclusions have higher Jd-content than the matrix omphacites in the same sample indicates that these omphacite inclusions might form under higher pressure (see Fig.4.5). During retrograde metamorphism, omphacite inclusions, like coesite and micro-diamond inclusions, were "protected" by the host garnet, so that they record information about prograde and/or peak metamorphism.

In one omphacite inclusion in garnet of retrograded eclogite from Bixiling, systematic variations in $\mathrm{K}_{2} \mathrm{O}$-content from rim to core have been observed. The highest $\mathrm{K}_{2} \mathrm{O}$ content in the rim of the inclusion is up to $1.08 \%$ (see table 4.3, $\mathrm{Nr} 3-5$ ), and by applying Wang and Takahashi's (1999) barometer, the peak metamorphic pressure would be up to $70 \mathrm{kbar}$. This estimate is much higher than a pressure of $\sim 30$ kbar indicated by the stability field of coesite, but coincides with a peak metamorphic pressure of 67 kbar estimated for coexisting ultramafic rocks by Zhang et al (1995). Figure 4.14 shows semi-quantitative maps for $\mathrm{Na}, \mathrm{Ca}, \mathrm{K}$ and $\mathrm{Fe}$ in a retrograded omphacite inclusion in garnet, indicating the $\mathrm{K}$-content in the grain is more or less systematical. An extremely high pressure was also postulated by the presence of $\mathrm{FeTiO}_{3}$ rods in olivine from Bixiling (Green II et al., 1997). However, because a $\mathrm{K}_{2} \mathrm{O}$ content of more than $1 \%$ has been measured in only one out of 15 measured grains, and also due to uncertainties of the 
applied barometer, further work is needed to verify such extremely high pressures in the Dabie Sulu area.

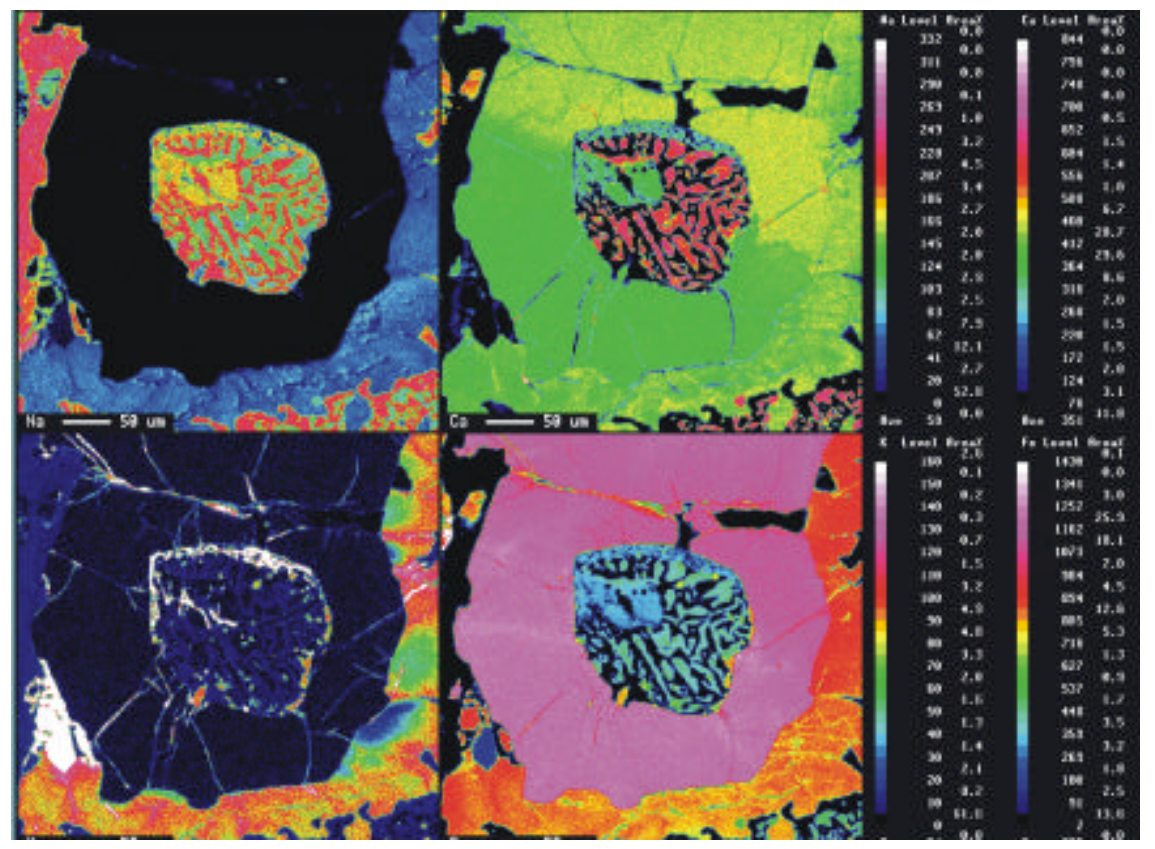

Fig. 4.14 Semiquantitative mapping of a retrograded omphacite inclusion in garnet from Bixiling. Note the K-contents in the rim of the grain are relatively high (lower left foto).

\subsection{Cl-rich amphibole in North Dabie Shan: indicators of Cl-enriched solutions}

During recent years, an increasing number of studies on Clrich amphibole (e.g., Dick and Robinson, 1979; Kamineni et al., 1982; Vanko, 1986; Gulyaeva et al., 1986; Suwa et al., 1987; Valley et al., 1990; Morrison, 1991; Zhu and Sverjensky, 1991; Oberti et al., 1993; Zhu et al., 1994; Kullerud, 1996; Markl and Bucher, 1998; Markl and Piazolo, 1998; Markl et al., 1998; Kullerud and Erambert, 1999) have promoted interest in both the crystal chemistry of $\mathrm{Cl}$ and the petrologic implications of $\mathrm{Cl}$ enrichment in amphibole. It is usually believed that $\mathrm{Cl}^{-}$substitutes for $\mathrm{OH}^{-}$in the crystal structures $\boldsymbol{f}$ amphiboles but such a substitution is limited because the ionic radius of $\mathrm{Cl}^{-}(1.81 \AA)$ is much larger than that of $\mathrm{OH}^{-}(1.35 \AA)$. So far Cl-rich amphiboles have been reported in granulites or granulite-facies rocks from the Black Rock Forest, Hudson highlands of New York (Leger et al., 1996), in Adirondack Mountains, New York (Valley et al., 1990; Morrison, 1991), in Lofoten Islands, Norway (Kullerud, 1996; Markl et al., 1998, Kullerud and Erambert, 1999) and in Antarctica (Suwa et al., 1987; Markl and Piazolo, 1998). 
Cl-rich amphiboles have been found in amphiboles from both Raobazhi eclogite and Yanzihe granulite. The Cl-content in amphiboles from Yanzihe is up to $4 \mathrm{wt} \%$, whereas that in amphiboles from Raobazhai is only 0.4 wt $\%$. Significant compositional zoning was observed within individual amphibole grains in the granulite from Yanzihe. Fig. 4. 15 shows minerals composed of Clrich amphibole, Ctpoor amphibole and orthopyroxene. The two types of amphiboles are in sharp contact, suggesting the two parts formed under different fluid conditions.
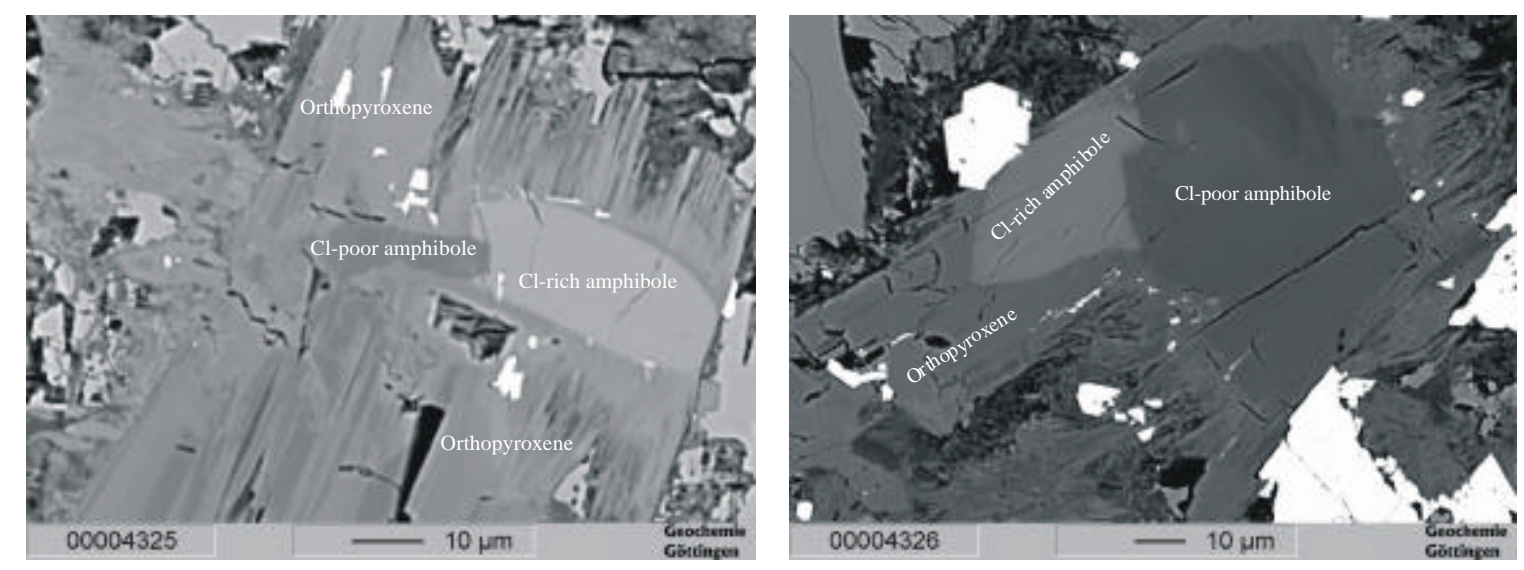

Fig.4. 15. Photomicrograph of Cl-rich amphibole in granulite from Raobazhai, NDC

Compositional variations in these amphiboles are listed in Table 4.5 and shown in Fig.4. 16, which plots atoms per formula unit against $\mathrm{Cl}$ per formula unit. The compositional variations are similar to the trends described by Kullerud (1996), Markl et al. (1998), and Kullerud and Erambert (1998). Positive correlations were observed among $\mathrm{Cl}, \mathrm{Al}, \mathrm{Fe}, \mathrm{K}, \mathrm{Ba}$, and negative correlations were observed among $\mathrm{Cl}, \mathrm{Si}, \mathrm{Mg}$; $\mathrm{Ti}, \mathrm{Ca}$ and $\mathrm{Na}$ apparently are uncorrelated to $\mathrm{Cl}$. However, median $\mathrm{Cl}$ contents (1-3 wt\%) have been rarely measured, thus $\mathrm{Cl}$ compositions could be approximately subdivided into two groups: a Cl-rich group and a Cl-poor group. This is consistence with the fact that the two areas are in sharp contact.

Amphiboles and micas provide the significant mineral reservoirs for $\mathrm{H}_{2} \mathrm{O}, \mathrm{Cl}$ and $\mathrm{F}$ in the Earth's crust. $\mathrm{Cl}$ is strongly partitioned into aqueous fluids relative to solid phases and only enters solid phases in significant amounts if the chlorinity of the fluid in high and/or the water activity is very low (Munoz and Swenson, 1981; Volfinger et al., 1985; Zhu and Sverjensky, 1991). Hence, even low amounts of $\mathrm{Cl}$ in biotite and amphibole indicate the existence of Cl-rich solutions. 

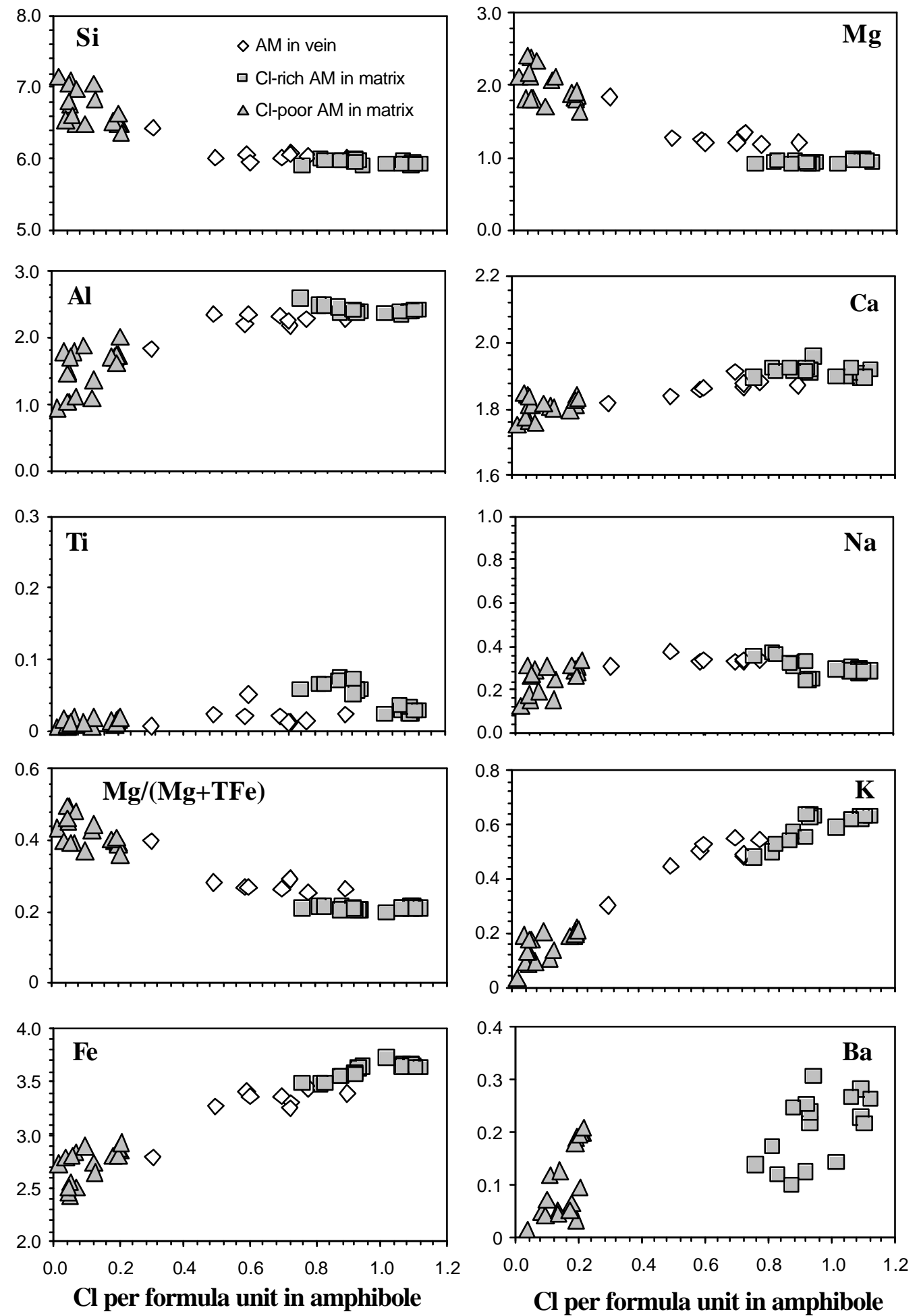

Fig. 4.16. Compositional variations of amphiboles in granulite from Yanzihe. 
Table 4.5 Selected microprobe analyses of amphiboles in the granulite from Yanzihe (* not measured)

\begin{tabular}{|c|c|c|c|c|c|c|c|c|c|c|c|c|c|c|c|c|c|c|c|}
\hline & $\begin{array}{c}\text { matrix } \\
\text { (Yanzihe) }\end{array}$ & & & & & & & & & & & & & & & & & & \\
\hline Nr. & 1 & 2 & 3 & 4 & 5 & 6 & 7 & 8 & 9 & 10 & 11 & 12 & 13 & 14 & 15 & 16 & 17 & 18 & 19 \\
\hline $\mathrm{SiO}_{2}$ & 37.50 & 36.95 & 37.46 & 37.41 & 47.37 & 48.85 & 48.36 & 48.21 & 47.70 & 43.53 & 43.03 & 43.21 & 43.62 & 45.87 & 44.27 & 37.16 & 36.98 & 37.11 & 36.98 \\
\hline $\mathrm{TiO}_{2}$ & 0.46 & 0.49 & 0.47 & 0.42 & 0.07 & 0.05 & 0.07 & 0.04 & 0.09 & 0.09 & 0.14 & 0.12 & 0.12 & 0.16 & 0.10 & 0.18 & 0.27 & 0.24 & 0.24 \\
\hline $\mathrm{Al}_{2} \mathrm{O}_{3}$ & 12.63 & 12.67 & 12.59 & 12.76 & 6.20 & 5.43 & 5.99 & 6.04 & 6.40 & 9.56 & 9.76 & 9.85 & 9.70 & 7.71 & 9.07 & 12.61 & 12.71 & 12.74 & 12.72 \\
\hline $\mathrm{Cr}_{2} \mathrm{O}_{3}$ & 0.03 & 0.01 & 0.00 & 0.00 & 0.00 & 0.00 & 0.01 & 0.00 & 0.00 & 0.01 & 0.00 & 0.01 & 0.05 & 0.00 & 0.03 & 0.00 & 0.00 & 0.01 & 0.00 \\
\hline $\mathrm{FeO}$ & 27.09 & 27.27 & 27.20 & 26.83 & 22.02 & 22.34 & 19.91 & 20.13 & 20.54 & 22.39 & 22.65 & 22.82 & 22.39 & 21.36 & 22.35 & 27.20 & 27.41 & 27.16 & 27.08 \\
\hline $\mathrm{MnO}$ & 0.25 & 0.25 & 0.25 & 0.24 & 0.29 & 0.45 & 0.37 & 0.35 & 0.32 & 0.34 & 0.31 & 0.34 & 0.33 & 0.34 & 0.32 & 0.29 & 0.29 & 0.30 & 0.28 \\
\hline $\mathrm{MgO}$ & 3.88 & 3.89 & 3.84 & 3.83 & 9.36 & 9.67 & 10.90 & 11.00 & 10.69 & 8.19 & 8.28 & 8.14 & 8.45 & 9.52 & 8.59 & 4.14 & 4.08 & 3.94 & 4.01 \\
\hline $\mathrm{CaO}$ & 11.16 & 11.42 & 11.22 & 11.22 & 11.35 & 11.19 & 11.23 & 11.32 & 11.21 & 11.21 & 11.41 & 11.25 & 11.21 & 11.31 & 11.39 & 11.09 & 11.17 & 11.20 & 11.04 \\
\hline $\mathrm{Na}_{2} \mathrm{O}$ & 0.77 & 0.79 & 0.80 & 0.76 & 0.54 & 0.42 & 0.55 & 0.63 & 0.66 & 0.99 & 1.05 & 0.97 & 1.07 & 0.85 & 0.89 & 0.93 & 0.89 & 0.91 & 0.90 \\
\hline $\mathrm{K}_{2} \mathrm{O}$ & 3.12 & 3.08 & 3.07 & 3.11 & 0.59 & 0.20 & 0.46 & 0.50 & 0.53 & 1.00 & 1.12 & 1.09 & 0.99 & 0.75 & 1.06 & 3.09 & 3.05 & 3.08 & 3.09 \\
\hline $\mathrm{Cl}$ & 3.46 & 3.49 & 3.46 & 3.41 & 0.48 & 0.06 & 0.20 & 0.17 & 0.29 & 0.74 & 0.78 & 0.78 & 0.71 & 0.50 & 0.77 & 4.05 & 4.06 & 4.16 & 4.08 \\
\hline $\mathrm{BaO}$ & 0.22 & 0.31 & 0.24 & 0.25 & 0.06 & 0.00 & 0.00 & 0.00 & 0.00 & 0.06 & 0.00 & 0.06 & 0.07 & 0.00 & 0.00 & 0.28 & 0.23 & 0.26 & 0.22 \\
\hline total & 100.55 & 100.61 & 100.60 & 100.24 & 98.32 & 98.66 & 98.04 & 98.40 & 98.44 & 98.10 & 98.53 & 98.63 & 98.70 & 98.36 & 98.83 & 101.02 & 101.13 & 101.11 & 100.63 \\
\hline Total corrected for $\mathrm{Cl}$ & 99.77 & 99.82 & 99.81 & 99.47 & 98.21 & 98.65 & 97.99 & 98.36 & 98.37 & 97.94 & 98.35 & 98.45 & 98.54 & 98.25 & 98.66 & 100.11 & 100.21 & 100.18 & 99.71 \\
\hline \multicolumn{20}{|c|}{$\Sigma$ cations $-(\mathrm{Ca}+\mathrm{Na}+\mathrm{K})=13$} \\
\hline $\mathrm{Si}$ & 5.98 & 5.91 & 5.97 & 5.98 & 7.05 & 7.15 & 7.09 & 7.05 & 6.99 & 6.57 & 6.49 & 6.50 & 6.53 & 6.82 & 6.63 & 5.92 & 5.89 & 5.93 & 5.92 \\
\hline $\mathrm{Ti}$ & 0.05 & 0.06 & 0.06 & 0.05 & 0.01 & 0.01 & 0.01 & 0.00 & 0.01 & 0.01 & 0.02 & 0.01 & 0.01 & 0.02 & 0.01 & 0.02 & 0.03 & 0.03 & 0.03 \\
\hline $\mathrm{Al}$ & 2.37 & 2.39 & 2.37 & 2.40 & 1.09 & 0.94 & 1.03 & 1.04 & 1.11 & 1.70 & 1.74 & 1.75 & 1.71 & 1.35 & 1.60 & 2.37 & 2.39 & 2.40 & 2.40 \\
\hline $\mathrm{Cr}$ & 0.00 & 0.00 & 0.00 & 0.00 & 0.00 & 0.00 & 0.00 & 0.00 & 0.00 & 0.00 & 0.00 & 0.00 & 0.01 & 0.00 & 0.00 & 0.00 & 0.00 & 0.00 & 0.00 \\
\hline $\mathrm{Fe}$ & 3.61 & 3.65 & 3.63 & 3.59 & 2.74 & 2.74 & 2.44 & 2.46 & 2.52 & 2.83 & 2.86 & 2.87 & 2.80 & 2.66 & 2.80 & 3.63 & 3.65 & 3.63 & 3.63 \\
\hline $\mathrm{Mn}$ & 0.03 & 0.03 & 0.03 & 0.03 & 0.04 & 0.06 & 0.05 & 0.04 & 0.04 & 0.04 & 0.04 & 0.04 & 0.04 & 0.04 & 0.04 & 0.04 & 0.04 & 0.04 & 0.04 \\
\hline $\mathrm{Mg}$ & 0.92 & 0.93 & 0.91 & 0.91 & 2.08 & 2.11 & 2.38 & 2.40 & 2.34 & 1.84 & 1.86 & 1.82 & 1.89 & 2.11 & 1.92 & 0.98 & 0.97 & 0.94 & 0.96 \\
\hline $\mathrm{Ca}$ & 1.91 & 1.96 & 1.92 & 1.92 & 1.81 & 1.76 & 1.76 & 1.77 & 1.76 & 1.81 & 1.84 & 1.81 & 1.80 & 1.80 & 1.83 & 1.89 & 1.91 & 1.92 & 1.89 \\
\hline $\mathrm{Na}$ & 0.24 & 0.24 & 0.25 & 0.24 & 0.16 & 0.12 & 0.15 & 0.18 & 0.19 & 0.29 & 0.31 & 0.28 & 0.31 & 0.24 & 0.26 & 0.29 & 0.27 & 0.28 & 0.28 \\
\hline $\mathrm{K}$ & 0.63 & 0.63 & 0.62 & 0.63 & 0.11 & 0.04 & 0.09 & 0.09 & 0.10 & 0.19 & 0.22 & 0.21 & 0.19 & 0.14 & 0.20 & 0.63 & 0.62 & 0.63 & 0.63 \\
\hline $\mathrm{Cl}$ & 0.93 & 0.95 & 0.94 & 0.92 & 0.12 & 0.02 & 0.05 & 0.04 & 0.07 & 0.19 & 0.20 & 0.20 & 0.18 & 0.13 & 0.20 & 1.09 & 1.10 & 1.13 & 1.11 \\
\hline $\mathrm{Ba}$ & 0.02 & 0.02 & 0.02 & 0.02 & 0.00 & 0.00 & 0.00 & 0.00 & 0.00 & 0.00 & 0.00 & 0.00 & 0.00 & 0.00 & 0.00 & 0.02 & 0.02 & 0.02 & 0.02 \\
\hline
\end{tabular}


Table 4.5 (continued)

\begin{tabular}{|c|c|c|c|c|c|c|c|c|c|c|c|c|c|c|c|c|c|c|c|}
\hline \multirow[b]{2}{*}{ No } & \multicolumn{3}{|c|}{$\begin{array}{c}\text { matrix } \\
\text { (Yanzihe) } \\
\end{array}$} & \multirow[b]{2}{*}{23} & \multirow[b]{2}{*}{24} & \multirow[b]{2}{*}{25} & \multirow[b]{2}{*}{26} & \multirow[b]{2}{*}{$2 i$} & \multirow[b]{2}{*}{28} & \multicolumn{3}{|c|}{$\begin{array}{l}\text { Vein in } \\
\text { garnet }\end{array}$} & \multirow[b]{2}{*}{32} & \multirow[b]{2}{*}{33} & \multirow[b]{2}{*}{34} & \multirow[b]{2}{*}{35} & \multicolumn{3}{|c|}{ Raobazhai } \\
\hline & 20 & 21 & 22 & & & & & & & 29 & 30 & 31 & & & & & 36 & 37 & 38 \\
\hline $\mathrm{SiO}_{2}$ & 37.06 & 37.18 & 45.56 & 45.82 & 41.84 & 43.70 & 43.76 & 44.1? & 43.06 & 38.12 & 38.64 & 37.74 & 38.30 & 37.86 & 37.95 & 38.60 & 38.66 & 41.43 & 41.06 \\
\hline $\mathrm{TiO}_{2}$ & 0.28 & 0.18 & 0.08 & 0.09 & 0.17 & 0.16 & 0.14 & 0.11 & 0.11 & 0.12 & 0.18 & 0.42 & 0.19 & 0.17 & 0.19 & 0.10 & 0.10 & 3.06 & 3.40 \\
\hline $\mathrm{Al}_{2} \mathrm{O}_{3}$ & 12.64 & 12.49 & 8.52 & 8.34 & 11.19 & 10.12 & 10.16 & $9.6 \mathrm{C}$ & 10.68 & 12.17 & 11.88 & 12.64 & 12.71 & 12.44 & 12.23 & 11.76 & 12.20 & 13.97 & 13.23 \\
\hline $\mathrm{Cr}_{2} \mathrm{O}_{3}$ & 0.00 & 0.00 & 0.00 & 0.00 & 0.03 & 0.01 & 0.04 & 0.01 & 0.00 & 0.01 & 0.00 & 0.00 & 0.02 & 0.02 & 0.00 & 0.00 & 0.02 & 0.08 & 0.10 \\
\hline $\mathrm{FeO}$ & 27.25 & 27.94 & 20.66 & 20.31 & 23.10 & 22.78 & 22.28 & $22.4 \mathrm{C}$ & 23.08 & 25.91 & 25.93 & 25.47 & 24.93 & 25.35 & 25.61 & 25.08 & 24.92 & 11.85 & 11.69 \\
\hline $\mathrm{MnO}$ & 0.31 & 0.33 & 0.47 & 0.43 & 0.36 & 0.38 & 0.33 & 0.32 & 0.31 & 0.39 & 0.48 & 0.57 & 0.58 & 0.52 & 0.51 & 0.46 & 0.55 & 0.10 & 0.10 \\
\hline $\mathrm{MgO}$ & 3.98 & 3.81 & 9.52 & 9.85 & 7.22 & 8.17 & 8.20 & 8.14 & 7.57 & 5.00 & 5.33 & 5.17 & 5.45 & 5.10 & 5.12 & 5.71 & 5.79 & 12.60 & 12.60 \\
\hline $\mathrm{CaO}$ & 11.22 & 11.11 & 11.40 & 11.61 & 11.27 & 11.37 & 11.55 & 11.44 & 11.31 & 11.09 & 11.04 & 11.02 & 10.93 & 11.25 & 11.03 & 11.05 & 11.21 & 11.26 & 11.24 \\
\hline $\mathrm{Na}_{2} \mathrm{O}$ & 0.92 & 0.94 & 0.93 & 0.90 & 1.15 & 0.99 & 1.07 & 0.92 & 1.05 & 1.08 & 1.07 & 1.10 & 1.22 & 1.06 & 1.06 & 1.08 & 1.11 & 3.51 & 3.55 \\
\hline $\mathrm{K}_{2} \mathrm{O}$ & 3.02 & 2.90 & 0.71 & 0.71 & 1.10 & 0.93 & 1.01 & 0.91 & 1.06 & 2.70 & 2.52 & 2.63 & 2.25 & 2.72 & 2.75 & 2.41 & 2.45 & 0.04 & 0.05 \\
\hline $\mathrm{Cl}$ & 3.93 & 3.77 & 0.21 & 0.18 & 0.81 & 0.26 & 0.14 & 0.21 & 0.39 & 2.89 & 2.21 & 2.24 & 1.86 & 2.59 & 3.33 & 2.71 & 2.72 & 0.41 & 0.39 \\
\hline $\mathrm{BaO}$ & 0.27 & 0.15 & 0.05 & 0.00 & 0.03 & 0.00 & 0.00 & $0.0 C$ & 0.00 & $*$ & $*$ & $*$ & $*$ & $*$ & * & $*$ & $*$ & * & $*$ \\
\hline total & 100.88 & 100.80 & 98.10 & 98.23 & 98.27 & 98.86 & 98.68 & 98.25 & 98.61 & 99.49 & 99.28 & 99.00 & 98.44 & 99.08 & 99.77 & 98.96 & 99.73 & 98.31 & 97.41 \\
\hline Total corrected for $\mathrm{Cl}$ & 99.99 & 99.95 & 98.05 & 98.19 & 98.08 & 98.80 & 98.65 & 98.24 & 98.53 & 98.83 & 98.78 & 98.49 & 98.02 & 98.49 & 99.02 & 98.35 & 99.11 & 98.22 & 97.32 \\
\hline \multicolumn{20}{|c|}{$\Sigma$ cations $-(\mathrm{Ca}+\mathrm{Na}+\mathrm{K})=13$} \\
\hline $\mathrm{Si}$ & 5.92 & 5.93 & 6.76 & 6.79 & 6.36 & 6.51 & 6.54 & 6.61 & 6.47 & 6.04 & 6.07 & 5.95 & 6.01 & 6.01 & 6.02 & 6.09 & 6.05 & 6.05 & 6.07 \\
\hline $\mathrm{Ti}$ & 0.03 & 0.02 & 0.01 & 0.01 & 0.02 & 0.02 & 0.02 & 0.01 & 0.01 & 0.01 & 0.02 & 0.05 & 0.02 & 0.02 & 0.02 & 0.01 & 0.01 & 0.34 & 0.38 \\
\hline $\mathrm{Al}$ & 2.38 & 2.35 & 1.49 & 1.46 & 2.00 & 1.78 & 1.79 & 1.71 & 1.89 & 2.27 & 2.20 & 2.35 & 2.35 & 2.33 & 2.29 & 2.19 & 2.25 & 2.40 & 2.31 \\
\hline $\mathrm{Cr}$ & 0.00 & 0.00 & 0.00 & 0.00 & 0.00 & 0.00 & 0.01 & $0.0 C$ & 0.00 & 0.00 & 0.00 & 0.00 & 0.00 & 0.00 & 0.00 & 0.00 & 0.00 & 0.01 & 0.01 \\
\hline $\mathrm{Fe}$ & 3.64 & 3.73 & 2.56 & 2.52 & 2.93 & 2.84 & 2.78 & 2.81 & 2.90 & 3.43 & 3.40 & 3.36 & 3.27 & 3.36 & 3.40 & 3.31 & 3.26 & 1.45 & 1.45 \\
\hline $\mathrm{Mn}$ & 0.04 & 0.04 & 0.06 & 0.05 & 0.05 & 0.05 & 0.04 & 0.04 & 0.04 & 0.05 & 0.06 & 0.08 & 0.08 & 0.07 & 0.07 & 0.06 & 0.07 & 0.01 & 0.01 \\
\hline $\mathrm{Mg}$ & 0.95 & 0.91 & 2.11 & 2.18 & 1.64 & 1.81 & 1.83 & 1.82 & 1.69 & 1.18 & 1.25 & 1.22 & 1.27 & 1.21 & 1.21 & 1.34 & 1.35 & 2.74 & 2.78 \\
\hline $\mathrm{Ca}$ & 1.92 & 1.90 & 1.81 & 1.84 & 1.83 & 1.81 & 1.85 & 1.84 & 1.82 & 1.88 & 1.86 & 1.86 & 1.84 & 1.91 & 1.87 & 1.87 & 1.88 & 1.76 & 1.78 \\
\hline $\mathrm{Na}$ & 0.28 & 0.29 & 0.27 & 0.26 & 0.34 & 0.29 & 0.31 & 0.27 & 0.31 & 0.33 & 0.33 & 0.34 & 0.37 & 0.32 & 0.32 & 0.33 & 0.34 & 0.99 & 1.02 \\
\hline K & 0.62 & 0.59 & 0.13 & 0.13 & 0.21 & 0.18 & 0.19 & 0.17 & 0.20 & 0.55 & 0.50 & 0.53 & 0.45 & 0.55 & 0.56 & 0.48 & 0.49 & 0.01 & 0.01 \\
\hline $\mathrm{Cl}$ & 1.06 & 1.02 & 0.05 & 0.05 & 0.21 & 0.06 & 0.04 & $0.0 \leftleftarrows$ & 0.10 & 0.78 & 0.59 & 0.60 & 0.49 & 0.70 & 0.89 & 0.72 & 0.72 & 0.10 & 0.10 \\
\hline $\mathrm{Ba}$ & 0.02 & 0.01 & 0.00 & 0.00 & 0.00 & 0.00 & 0.00 & $0.0 C$ & 0.00 & 0.00 & 0.00 & 0.00 & 0.00 & 0.00 & $0.0 \mathrm{C}$ & 0.00 & 0.00 & 0.00 & 0.00 \\
\hline
\end{tabular}




\section{Chapter 5. MAJOR AND TRACE ELEMENTS GEOCHEMISTRY}

\subsection{Whole -rock geochemical characteristics}

To understand the relationships between fluid composition and metamorphism, and the way a fluid phase is involved in mineral reactions during high- and ultrahigh-pressure metamorphism, it is necessary to study not only minerals, but also the whole-rock chemical compositions of the investigated rocks. For this purpose, samples from all six investigated localities, as well as some other eclogites and gneisses from the SDT were selected for wholerock compositional analysis.

\subsubsection{Major elements}

The studied samples display a broad compositional range (Table 5.1). In eclogites concentrations of $\mathrm{SiO}_{2}$ vary from 43 to $60 \mathrm{wt} \%$, although most samples cluster around 50\%; the $\mathrm{Al}_{2} \mathrm{O}_{3}$ contents are between 9.8 and $18.80 \mathrm{wt} \%$; $\mathrm{TiO}_{2}$ and $\mathrm{K}_{2} \mathrm{O}+\mathrm{Na}_{2} \mathrm{O}$ contents vary from 0.2 to $4.88 \mathrm{wt} \%$ and 0.9 to $5 \%$, respectively. Granulite from Yanzihe and jadeite quartzite from Shuanghe have $\mathrm{SiO}_{2}$-contents up to 74 and $73.8 \mathrm{wt} \%$ respectively, even higher than most gneisses, which have $\mathrm{SiO}_{2}$ contents between 60 and $71.40 \mathrm{wt} \%$ (Xiao, 1991); their $\mathrm{TiO}_{2}$ contents are between 0.03 and $0.51 \mathrm{wt} \%$, respectively. A classification in terms of the total alkalis $\left(\mathrm{Na}_{2} \mathrm{O}+\mathrm{K}_{2} \mathrm{O}\right)$ versus silica (TAS) diagram for the analyzed samples is given in Fig. 5.1. As most eclogites in the Dabie-Sulu area represent closed systems during metamorphism (e.g., Yui et al., 1995; Zheng et al., 1996, 1998; Rumble and Yui, 1998; Xiao et al., 2000, 2001), alkali elements have not been largely mobilized, and thus this traditional classification is still applicable. Eclogites which fall into the basalt field predominate, whereas a few fall into the picro-basalt or basaltic andesite field; only one sample, which is relatively quartz rich, lies in the andesite field. Garnet peridotite associated with eclogites in Bixiling (DB10) and Shima (DB64, 66) fall into the picro-basalt field. Granulites from Yanzihe lie in the dacite field. You et al. (1996) and Liou et al. (1997) suggested a sedimentary origin for the jadeite quartzite in Shuanghe, thus these samples have not plotted in the diagram. On the other hand, for comparison, data from Xiao (1991) for gneisses from the SDT are also presented and classified as andesite, dacite and rhyolite in the diagram. The large compositional variability observed in the eclogite samples is explained to be due to both igneous (heterogeneous protoliths) and metamorphic processes, and in some cases, compounded by metasomatic effects (Jahn, 1998). 
In a plot of $\mathrm{K}_{2} \mathrm{O}$ versus $\mathrm{SiO}_{2}$ (Fig. 5.2) the samples plot within the low- to medium-K fields. All the gneiss samples and non-coesite-bearing eclogite samples from Lidu generally plot in the medium-K field whereas those from other investigated eclogite localities have lower $\mathrm{K}_{2} \mathrm{O}$ contents, plotting in the low $-\mathrm{K}$ field. Granulite from Yanzihe and jadeite quartzite from Shuanghe plot also within low-K field. On the AFM diagram (Fig. 5.3), all samples of eclogites, granulite and meta-ultamafic rocks show distinct Fe-enrichment trends, characteristic of tholeiitic series, whereas samples of gneiss and jadeite quartzite fall into the calc-alkaline field.

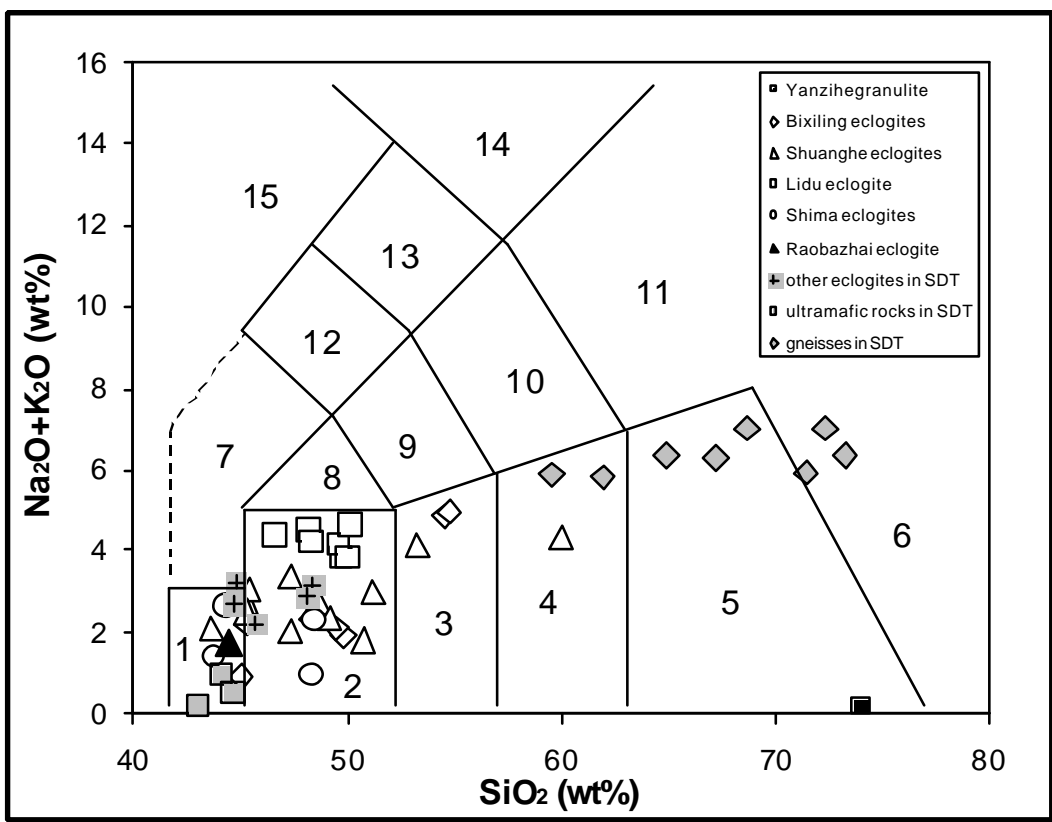

Fig. 5.1. Total alkalis versus silica (TAS) diagram showing the classification of the metamorphic rocks from Dabie Shan. After Le Maitre et al. (1989). 1 Picro-basalt, 2 Basalt, 3 Basaltic andesite, 4 Andesite, 5 Dacite, 6 Rhyolite; other symboles see Le Maitre et al. (1989).

Fig. 5.2. Variation of $\mathrm{K}_{2} \mathrm{O}$ versus $\mathrm{SiO}_{2}$ showing the classification of the metamorphic rocks from Dabie Shan as Low - and Medium-K series. After Le Maitre et al. (1989) 


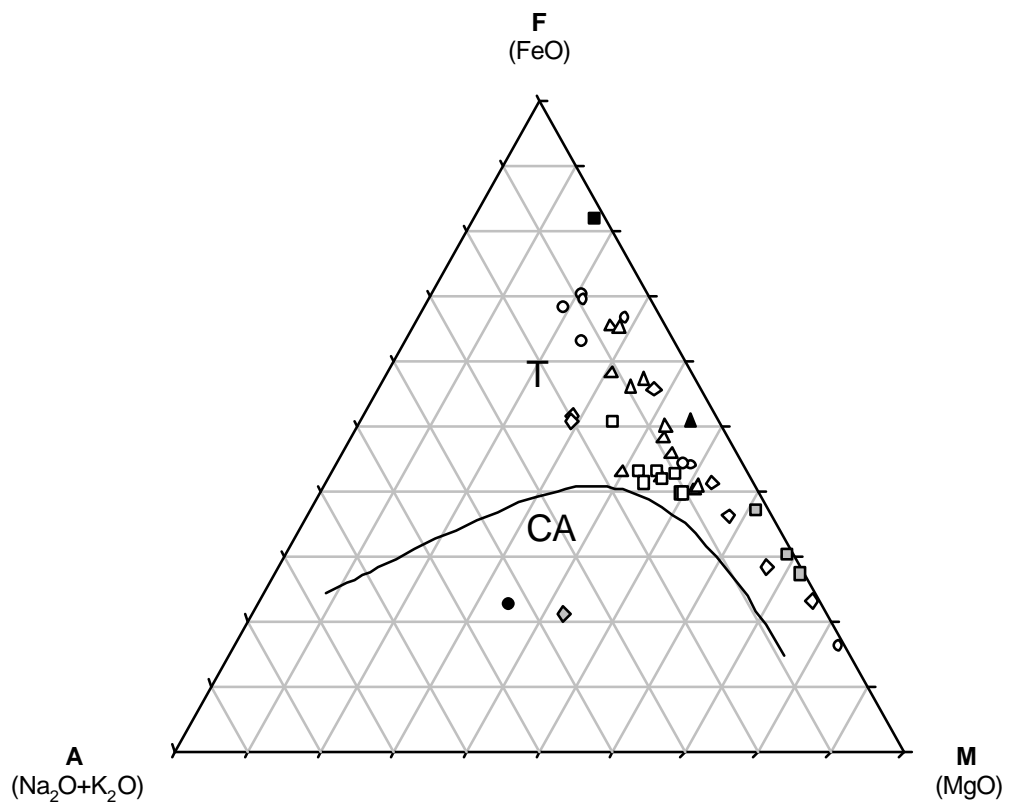

Fig. 5.3. AFM diagram for the metamorphic rocks from Dabie Shan. It is shown that most eclogites belong to tholeiitic series. $\mathrm{T}$ (tholeiitic) - $\mathrm{CA}$ (calc-alkaline) discriminating limit after Irvine and Baragar (1971). Symbols as in Fig. 5.2.

Although the eclogites, ultramafic rocks, granulite and gneiss are broadly similar in composition to tholeiites, there are significant chemical differences between these rocks, particularly in the concentrations of $\mathrm{MgO}, \mathrm{SiO}_{2}, \mathrm{FeO}, \mathrm{CaO}, \mathrm{Na}_{2} \mathrm{O}+\mathrm{K}_{2} \mathrm{O}, \mathrm{TiO}_{2}, \mathrm{P}_{2} \mathrm{O}_{5}$ and $\mathrm{Zr}$ (Fig. 5.4). The observed large compositional variability may be explained by the heterogeneity of the protoliths and a possible metasomatism before, during or after eclogite-facies metamorphism. The heterogeneity of protoliths includes the original variation in source compositions which gave rise to basaltic or gabbroic rocks, and the contrasting chemistry between cumulate rocks and residual liquids (Jahn, 1998). Granulite and jadeite quartzite are distinctly distinguishable from the eclogites. 

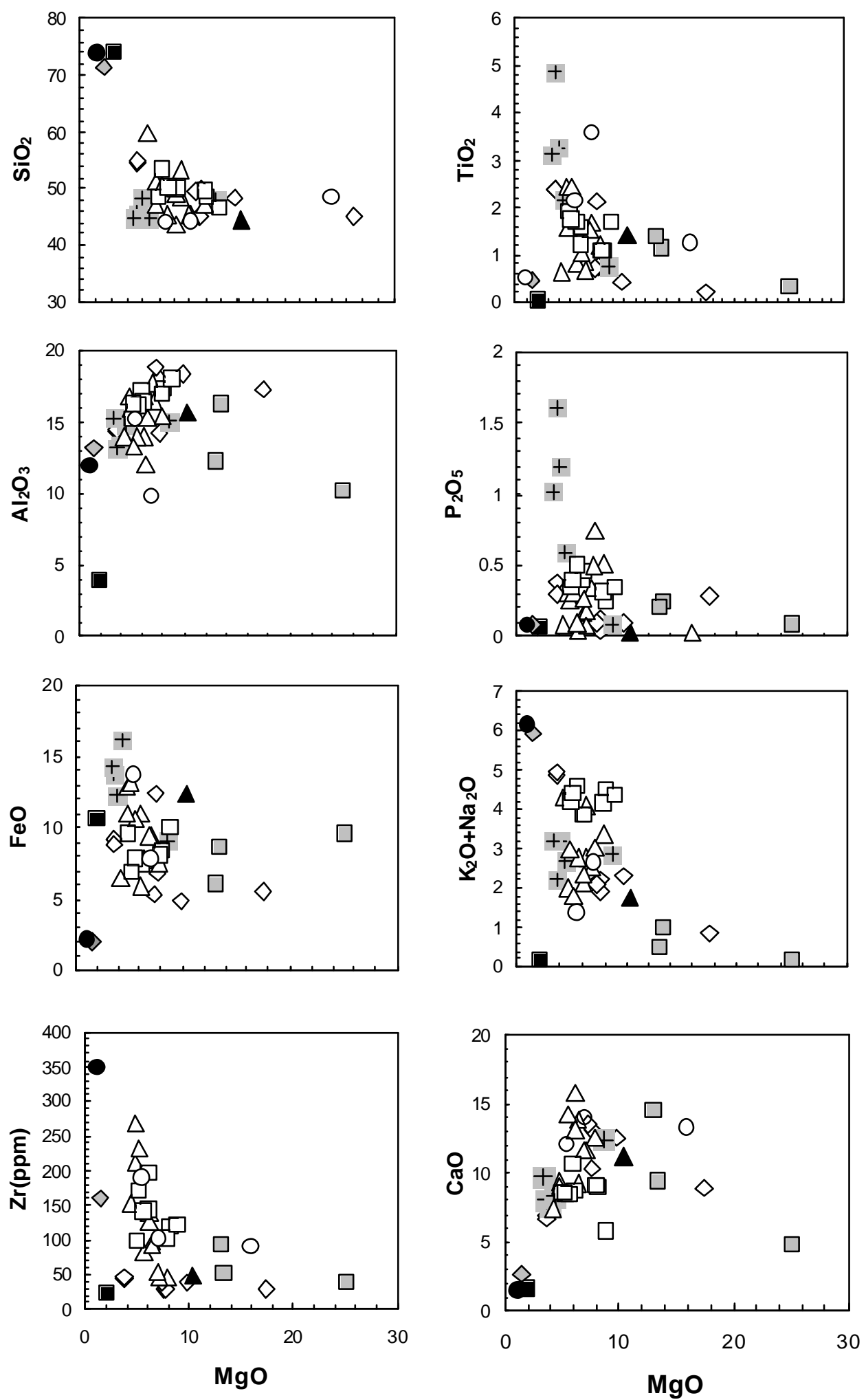

Fig. 5.4 Major element variations of the metamorphic rocks from Dabie Shan. No clear relation is visible among the investigated samples. Symbols as in Fig. 5.2. 
Table 5.1 Major- and trace-element data of the investigated samples from Dabie Shan

\begin{tabular}{cccccccccccc}
\hline Locality & Bixiling & \multicolumn{1}{c}{ Shuanghe } \\
\hline Sample & DB02 & DB05 & DB07 & DB08 & DB10 & DB11 & DB28 & DB29 & DB30 & DB31 & DB32 \\
$\mathrm{SiO}_{2}$ & 45.00 & 45.20 & 49.80 & 49.50 & 43.10 & 48.30 & 43.60 & 48.60 & 45.30 & 73.80 & 47.30 \\
$\mathrm{TiO}_{2}$ & 0.20 & 2.13 & 0.76 & 0.71 & 0.33 & 0.42 & 0.85 & 0.85 & 0.81 & 0.51 & 2.45 \\
$\mathrm{Al}_{2} \mathrm{O}_{3}$ & 17.30 & 14.20 & 18.00 & 18.80 & 10.10 & 18.40 & 14.00 & 12.00 & 14.00 & 11.90 & 16.80 \\
$\mathrm{FeO}$ & 5.58 & 12.36 & 6.78 & 5.35 & 9.55 & 4.83 & 11.00 & 7.75 & 10.62 & 2.13 & 12.81 \\
$\mathrm{Fe}_{2} \mathrm{O} 3$ & 3.92 & 4.72 & 1.17 & 1.95 & 5.01 & 2.41 & 2.05 & 3.28 & 1.65 & 2.30 & 2.84 \\
$\mathrm{MnO}$ & 0.15 & 0.21 & 0.15 & 0.13 & 0.23 & 0.14 & 0.20 & 0.14 & 0.21 & 0.03 & 0.22 \\
$\mathrm{MgO}$ & 17.46 & 7.55 & 7.67 & 7.34 & 25.12 & 9.81 & 6.12 & 6.41 & 5.61 & 1.12 & 4.78 \\
$\mathrm{CaO}$ & 8.86 & 10.34 & 13.20 & 13.56 & 4.75 & 12.53 & 15.90 & 13.87 & 14.26 & 1.44 & 9.40 \\
$\mathrm{Na} 2 \mathrm{O}$ & 0.86 & 2.17 & 1.84 & 2.06 & 0.14 & 2.18 & 2.01 & 2.66 & 2.71 & 5.94 & 1.98 \\
$\mathrm{~K}_{2} \mathrm{O}$ & 0.01 & 0.07 & 0.09 & 0.02 & 0.01 & 0.13 & 0.11 & 0.12 & 0.06 & 0.19 & 0.04 \\
$\mathrm{P}_{2} \mathrm{O}_{5}$ & 0.28 & 0.12 & 0.04 & 0.10 & 0.08 & 0.10 & 0.16 & 0.18 & 0.03 & 0.07 & 0.30 \\
$\mathrm{H}_{2} \mathrm{O}$ & 0.08 & 0.19 & 0.01 & 0.03 & 1.20 & 0.31 & 0.90 & 1.15 & 0.59 & 0.38 & 0.42 \\
$\mathrm{C}$ & 0.01 & $<0,01$ & 0.01 & $<0,01$ & 0.09 & 0.02 & 0.49 & 0.24 & 0.85 & $<0,01$ & $<0,01$ \\
$\mathrm{~S}$ & 0.01 & $<0,01$ & 0.04 & 0.13 & 0.05 & $<0,01$ & 0.38 & 0.64 & 0.07 & $<0,01$ & 0.01 \\
$\mathrm{Sum}(\%)$ & 99.71 & 99.26 & 99.55 & 99.68 & 99.75 & 99.58 & 97.77 & 97.87 & 96.77 & 99.81 & 99.35
\end{tabular}

Trace element (ppm)

XRF data

\begin{tabular}{|c|c|c|c|c|c|c|c|c|c|c|c|}
\hline \\
\hline $\mathrm{Nb}$ & $<5$ & $<5$ & $<5$ & $<5$ & $<5$ & $<5$ & 7 & 6 & 5 & 14 & 17 \\
\hline $\mathrm{Zr}$ & 30 & 30 & 30 & 40 & 39 & 38 & 139 & 97 & 83 & 349 & 268 \\
\hline $\mathrm{Y}$ & 5.45 & 14 & 13 & 14 & 6.76 & 12 & 27 & 22 & 24 & 39 & 50 \\
\hline $\mathrm{Sr}$ & 250 & 156 & 344 & 499 & 142 & 102 & 102 & 112 & 99 & 18 & 67 \\
\hline $\mathrm{Ga}$ & 12 & 18 & 16 & 15 & 11 & 14 & 12 & 14 & 15 & 16 & 20 \\
\hline $\mathrm{Zn}$ & 67 & 92 & 48 & 47 & 113 & 48 & 116 & 121 & 107 & 15 & 104 \\
\hline $\mathrm{Cu}$ & 20 & 94 & 47 & 168 & 56 & 101 & 50 & 74 & 24 & $<5$ & 21 \\
\hline $\mathrm{Ni}$ & 289 & 53 & 70 & 97 & 861 & 104 & 44 & 54 & 53 & $<5$ & 46 \\
\hline $\mathrm{Co}$ & 79 & 73 & 34 & 35 & 128 & 42 & 41 & 65 & 46 & $<5$ & 47 \\
\hline $\mathrm{Cr}$ & 357 & 181 & 263 & 633 & 2351 & 803 & 102 & 99 & 181 & 5 & 93 \\
\hline $\mathrm{V}$ & 45 & 665 & 210 & 179 & 80 & 104 & 214 & 240 & 202 & 19 & 211 \\
\hline $\mathrm{Ba}$ & 290 & 75 & 39 & 23 & 9 & 56 & 43 & 41 & 29 & 48 & 14 \\
\hline $\mathrm{Sc}$ & 13 & 44 & 37 & 43 & 16 & 32 & 40 & 32 & 36 & 7 & 28 \\
\hline \multicolumn{12}{|c|}{ ICP-MS data } \\
\hline $\mathrm{Sc}$ & 9.88 & 48.17 & 37.2 & 36.74 & 12.46 & 30.65 & & 29.5 & & 7.4 & 30.1 \\
\hline $\mathrm{Rb}$ & 21.72 & 2.33 & 3.09 & 0.52 & 0.56 & 2.54 & & 2.10 & & 3.88 & 2.51 \\
\hline $\mathrm{Sr}$ & 241.07 & 144.73 & 326 & 499.08 & 139.73 & 113.91 & & 103 & & 17 & 67 \\
\hline $\mathrm{Y}$ & 5.45 & 12.24 & 10.9 & 12.22 & 6.76 & 9.14 & & 18.3 & & 28.2 & 43.8 \\
\hline $\mathrm{La}$ & 17.01 & 3.39 & 4.06 & 5.28 & 1.84 & 0.48 & & 2.31 & & 43.23 & 7.44 \\
\hline $\mathrm{Ce}$ & 33.03 & 8.79 & 10.83 & 12.57 & 4.76 & 1.10 & & 5.28 & & 91.73 & 22.58 \\
\hline $\operatorname{Pr}$ & 3.55 & 1.39 & 1.65 & 1.76 & 0.71 & 0.17 & & 0.79 & & 9.70 & 3.36 \\
\hline $\mathrm{Nd}$ & 12.92 & 7.20 & 8.52 & 8.44 & 3.46 & 0.83 & & 3.98 & & 37.58 & 16.81 \\
\hline $\mathrm{Sm}$ & 1.78 & 1.83 & 2.14 & 1.98 & 0.91 & 0.31 & & 1.31 & & 7.33 & 5.24 \\
\hline $\mathrm{Eu}$ & 0.77 & 0.77 & 0.91 & 0.90 & 0.40 & 0.22 & & 0.44 & & 1.26 & 1.77 \\
\hline $\mathrm{Gd}$ & 1.84 & 2.34 & 2.33 & 2.34 & 1.17 & 0.76 & & 1.91 & & 6.90 & 7.09 \\
\hline $\mathrm{Tb}$ & 0.21 & 0.37 & 0.38 & 0.38 & 0.19 & 0.21 & & 0.42 & & 0.96 & 1.26 \\
\hline Dy & 1.09 & 2.29 & 1.99 & 2.23 & 1.25 & 1.58 & & 2.99 & & 5.28 & 7.93 \\
\hline Ho & 0.23 & 0.49 & 0.39 & 0.49 & 0.25 & 0.36 & & 0.70 & & 1.15 & 1.60 \\
\hline $\mathrm{Er}$ & 0.64 & 1.34 & 1.26 & 1.42 & 0.76 & 1.03 & & 2.28 & & 3.14 & 4.82 \\
\hline $\mathrm{Tm}$ & 0.09 & 0.20 & 0.16 & 0.20 & 0.12 & 0.16 & & 0.36 & & 0.52 & 0.72 \\
\hline $\mathrm{Yb}$ & 0.55 & 1.22 & 1.16 & 1.21 & 0.73 & 0.89 & & 2.19 & & 3.27 & 4.80 \\
\hline $\mathrm{Lu}$ & 0.10 & 0.21 & 0.18 & 0.22 & 0.13 & 0.14 & & 0.32 & & 0.50 & 0.71 \\
\hline $\mathrm{Pb}$ & 3.44 & 2.36 & 0.65 & 4.03 & 2.72 & 1.38 & & 4.06 & & 0.74 & 1.15 \\
\hline $\mathrm{Th}$ & 1.36 & 0.37 & 0.27 & 0.50 & 0.24 & 0.07 & & 3.60 & & 14.86 & 0.62 \\
\hline $\mathrm{U}$ & 0.08 & 0.07 & 0.05 & 0.12 & 0.06 & 0.03 & & 5.18 & & 2.11 & 0.36 \\
\hline
\end{tabular}


Table 5.1 continued

\begin{tabular}{cccccccccccc}
\hline Locality & \multicolumn{1}{l}{ Shuanghe } & \multicolumn{1}{l}{ Lidu } \\
\hline Sample & DB33 & DB34 & DB36 & DB37 & DB38 & DB39 & DB40 & DB41 & DB44 & DB45 & DB48 \\
$\mathrm{SiO}_{2}$ & 60.00 & 51.20 & 53.30 & 50.70 & 47.30 & 45.40 & 45.30 & 49.10 & 49.70 & 48.20 & 49.60 \\
$\mathrm{TiO}_{2}$ & 0.64 & 1.55 & 0.68 & 2.44 & 1.22 & 1.68 & 1.52 & 1.05 & 1.20 & 1.08 & 1.07 \\
$\mathrm{Al}_{2} \mathrm{O}_{3}$ & 14.00 & 16.00 & 15.30 & 13.30 & 15.40 & 16.50 & 17.80 & 16.80 & 17.20 & 17.30 & 16.90 \\
$\mathrm{FeO}$ & 6.46 & 10.91 & 7.72 & 13.14 & 7.54 & 9.38 & 9.43 & 5.83 & 7.55 & 8.35 & 8.01 \\
$\mathrm{Fe}_{2} \mathrm{O}_{3}$ & 1.99 & 1.97 & 1.69 & 3.06 & 3.19 & 3.87 & 3.61 & 4.22 & 2.79 & 1.91 & 1.93 \\
$\mathrm{MnO}$ & 0.11 & 0.17 & 0.14 & 0.20 & 0.19 & 0.18 & 0.18 & 0.17 & 0.17 & 0.19 & 0.17 \\
$\mathrm{MgO}$ & 4.28 & 4.85 & 6.47 & 5.22 & 7.88 & 7.10 & 6.92 & 6.13 & 6.05 & 8.16 & 7.98 \\
$\mathrm{CaO}$ & 7.46 & 9.03 & 9.24 & 8.58 & 12.60 & 11.70 & 11.76 & 13.19 & 10.66 & 8.85 & 9.07 \\
$\mathrm{Na}{ }_{2} \mathrm{O}$ & 4.02 & 2.96 & 3.93 & 1.78 & 3.20 & 2.75 & 2.26 & 2.28 & 3.72 & 3.08 & 3.22 \\
$\mathrm{~K}_{2} \mathrm{O}$ & 0.28 & 0.04 & 0.18 & 0.03 & 0.18 & 0.30 & 0.27 & 0.05 & 0.12 & 1.40 & 0.91 \\
$\mathrm{P}_{2} \mathrm{O}$ & 0.08 & 0.25 & 0.07 & 0.31 & 0.51 & 0.75 & 0.34 & 0.26 & 0.39 & 0.23 & 0.31 \\
$\mathrm{H}_{2} \mathrm{O}$ & 0.58 & 0.14 & 0.49 & 0.71 & 0.25 & 0.72 & 0.93 & 0.52 & 0.63 & 1.35 & 0.99 \\
$\mathrm{C}$ & $<0,01$ & $<0,01$ & $<0,01$ & $<0,01$ & $<0,01$ & $<0,01$ & $<0,01$ & $<0,01$ & $<0,01$ & $<0,01$ & $<0,01$ \\
$\mathrm{~S}$ & $<0,01$ & 0.01 & 0.01 & 0.02 & $<0,01$ & $<0,01$ & $<0,01$ & $<0,01$ & $<0,01$ & $<0,01$ & $<0,01$ \\
$\mathrm{Sum}(\%)$ & 99.90 & 99.08 & 99.22 & 99.49 & 99.45 & 100.33 & 100.32 & 99.60 & 100.18 & 100.10 & 100.15
\end{tabular}

\section{Trace element (ppm)}

\begin{tabular}{|c|c|c|c|c|c|c|c|c|c|c|c|}
\hline \multicolumn{12}{|c|}{ XRF data } \\
\hline $\mathrm{Nb}$ & 6 & 11 & 8 & 21 & $<5$ & $<5$ & $<5$ & $<5$ & 6 & 6 & $<5$ \\
\hline $\mathrm{Zr}$ & 153 & 211 & 93 & 232 & 47 & 46 & 53 & 127 & 143 & 118 & 101 \\
\hline $\mathrm{Y}$ & 23 & 38 & 16 & 36 & 17 & 18 & 21 & 25 & 26 & 24 & 22 \\
\hline $\mathrm{Sr}$ & 40 & 77 & 99 & 155 & 558 & 688 & 941 & 823 & 724 & 440 & 459 \\
\hline $\mathrm{Ga}$ & 21 & 21 & 17 & 20 & 18 & 18 & 21 & 19 & 20 & 16 & 16 \\
\hline $\mathrm{Zn}$ & 86 & 104 & 104 & 119 & 87 & 91 & 80 & 82 & 89 & 94 & 96 \\
\hline $\mathrm{Cu}$ & 14 & 14 & 43 & 147 & 25 & 39 & 41 & 45 & 37 & 41 & 58 \\
\hline $\mathrm{Ni}$ & 85 & 72 & 94 & 57 & 22 & 39 & 43 & 92 & 49 & 105 & 90 \\
\hline Co & 32 & 41 & 37 & 59 & 35 & 44 & 46 & 35 & 35 & 46 & 44 \\
\hline $\mathrm{Cr}$ & 201 & 97 & 399 & 36 & 159 & 116 & 94 & 268 & 184 & 239 & 222 \\
\hline $\mathrm{V}$ & 180 & 228 & 199 & 322 & 268 & 311 & 316 & 237 & 266 & 225 & 241 \\
\hline $\mathrm{Ba}$ & 58 & 16 & 57 & 53 & 102 & 188 & 200 & 50 & 87 & 824 & 571 \\
\hline $\mathrm{Sc}$ & 19 & 25 & 32 & 32 & 48 & 40 & 40 & 36 & 28 & 35 & 32 \\
\hline \multicolumn{12}{|c|}{ ICP-MS data } \\
\hline $\mathrm{Sc}$ & & & & & & & & & 28.3 & 29.1 & 26.7 \\
\hline $\mathrm{Rb}$ & & & & & & & & & 2.85 & 34.59 & 21.68 \\
\hline $\mathrm{Sr}$ & & & & & & & & & 678 & 407 & 455 \\
\hline $\mathrm{Y}$ & & & & & & & & & 22.5 & 19.4 & 17.0 \\
\hline $\mathrm{La}$ & & & & & & & & & 18.91 & 12.82 & 13.41 \\
\hline $\mathrm{Ce}$ & & & & & & & & & 40.88 & 28.16 & 30.29 \\
\hline $\operatorname{Pr}$ & & & & & & & & & 5.12 & 3.53 & 3.65 \\
\hline $\mathrm{Nd}$ & & & & & & & & & 22.95 & 16.02 & 16.98 \\
\hline $\mathrm{Sm}$ & & & & & & & & & 4.73 & 3.57 & 3.99 \\
\hline $\mathrm{Eu}$ & & & & & & & & & 1.58 & 1.55 & 1.62 \\
\hline $\mathrm{Gd}$ & & & & & & & & & 4.97 & 3.69 & 4.01 \\
\hline $\mathrm{Tb}$ & & & & & & & & & 0.69 & 0.58 & 0.56 \\
\hline Dy & & & & & & & & & 4.01 & 3.56 & 3.17 \\
\hline Ho & & & & & & & & & 0.85 & 0.75 & 0.70 \\
\hline $\mathrm{Er}$ & & & & & & & & & 2.54 & 2.10 & 1.79 \\
\hline $\mathrm{Tm}$ & & & & & & & & & 0.35 & 0.36 & 0.32 \\
\hline $\mathrm{Yb}$ & & & & & & & & & 2.33 & 2.04 & 1.75 \\
\hline $\mathrm{Lu}$ & & & & & & & & & 0.33 & 0.33 & 0.29 \\
\hline $\mathrm{Pb}$ & & & & & & & & & 8.91 & 9.03 & 7.41 \\
\hline $\mathrm{Th}$ & & & & & & & & & 1.79 & 1.71 & 1.23 \\
\hline $\mathrm{U}$ & & & & & & & & & 0.28 & 0.26 & 0.21 \\
\hline
\end{tabular}


Table 5.1 continued

\begin{tabular}{|c|c|c|c|c|c|c|c|c|c|c|c|c|}
\hline Locality & Lidu & & & & Shima & & & & & & Raobazhai & Yanzihe \\
\hline Sample & DB50 & DB53 & DB58 & DB59 & DB61 & DB63 & DB64 & DB65 & DB66 & & R-14 & $\mathrm{ml}-1$ \\
\hline $\mathrm{SiO}_{2}$ & 46.60 & 50.00 & 48.30 & 50.20 & 43.80 & 44.30 & 44.10 & 48.30 & 44.70 & & 44.50 & 74.00 \\
\hline $\mathrm{TiO}_{2}$ & 1.65 & 1.57 & 1.92 & 1.68 & 2.13 & 3.60 & 1.15 & 1.24 & 1.38 & & 1.42 & 0.03 \\
\hline $\mathrm{Al}_{2} \mathrm{O}_{3}$ & 18.00 & 16.40 & 15.20 & 16.10 & 15.20 & 9.80 & 16.20 & 10.90 & 12.20 & & 15.70 & 3.90 \\
\hline $\mathrm{FeO}$ & 9.98 & 7.32 & 9.54 & 7.77 & 13.67 & 7.71 & 8.60 & 3.26 & 5.95 & & 12.40 & 10.60 \\
\hline $\mathrm{Fe}_{2} \mathrm{O}_{3}$ & 3.55 & 4.60 & 5.15 & 3.44 & 1.57 & 6.27 & 5.14 & 5.57 & 6.92 & & 1.84 & 6.28 \\
\hline $\mathrm{MnO}$ & 0.24 & 0.19 & 0.26 & 0.23 & 0.28 & 0.18 & 0.28 & 0.18 & 0.28 & & 0.32 & 0.65 \\
\hline $\mathrm{MgO}$ & 8.91 & 6.18 & 5.04 & 5.64 & 5.44 & 7.05 & 13.45 & 16.00 & 13.07 & & 10.32 & 2.10 \\
\hline $\mathrm{CaO}$ & 5.71 & 8.64 & 8.58 & 8.40 & 12.03 & 14.07 & 9.39 & 13.31 & 14.50 & & 11.16 & 1.62 \\
\hline $\mathrm{Na}_{2} \mathrm{O}$ & 3.39 & 3.29 & 3.88 & 3.44 & 1.16 & 2.62 & 0.96 & 0.91 & 0.47 & & 1.68 & 0.12 \\
\hline $\mathrm{K}_{2} \mathrm{O}$ & 0.98 & 0.57 & 0.32 & 1.13 & 0.21 & 0.03 & 0.02 & 0.02 & 0.01 & & 0.05 & 0.07 \\
\hline $\mathrm{P}_{2} \mathrm{O}_{5}$ & 0.34 & 0.45 & 0.34 & 0.49 & 0.10 & 0.50 & 0.24 & 0.02 & 0.21 & & 0.03 & 0.06 \\
\hline $\mathrm{H}_{2} \mathrm{O}$ & 0.97 & 1.07 & 1.23 & 1.19 & 0.39 & 0.53 & 0.14 & 0.41 & 0.33 & ${ }^{143} \mathrm{Nd} /{ }^{144} \mathrm{Nd}$ & 0.513286 & 0.512299 \\
\hline $\mathrm{C}$ & $<0,01$ & 0.02 & 0.01 & 0.05 & 1.81 & 0.31 & 0.01 & 0.02 & 0.01 & $2 \sigma$ & 0.000007 & 0.000004 \\
\hline S & $<0,01$ & $<0,01$ & $<0,01$ & $<0,01$ & 0.02 & 2.06 & 0.01 & $<0,01$ & $<0,01$ & $\varepsilon_{\mathrm{Nd}}(0)$ & 12.60 & -6.30 \\
\hline $\operatorname{Sum}(\%)$ & 100.32 & 100.30 & 99.76 & 99.77 & 97.80 & 99.03 & 99.69 & 100.14 & 100.02 & & 99.41 & 99.43 \\
\hline
\end{tabular}

\section{Trace element (ppm)}

\section{XRF data}

\begin{tabular}{|c|c|c|c|c|c|c|c|c|c|c|c|}
\hline $\mathrm{Nb}$ & 5 & 8 & $<5$ & $<5$ & 22 & 13 & 11 & 14 & 11 & 6 & $<5$ \\
\hline $\mathrm{Zr}$ & 121 & 197 & 98 & 140 & 188 & 101 & 51 & 89 & 92 & 48 & 23 \\
\hline $\mathrm{Y}$ & 28 & 29 & 31 & 34 & 47.7 & 24 & 36 & 23 & 34 & 31 & 10 \\
\hline $\mathrm{Sr}$ & 115 & 509 & 192 & 372 & 90 & 95 & 201 & 336 & 163 & 94 & 10 \\
\hline $\mathrm{Ga}$ & 17 & 20 & 21 & 19 & 12 & 17 & 12 & 15 & 14 & 14 & 5 \\
\hline $\mathrm{Zn}$ & 101 & 123 & 125 & 102 & 112 & 106 & 50 & 35 & 61 & 39 & 48 \\
\hline $\mathrm{Cu}$ & 50 & 28 & 40 & 32 & 11 & 15 & 126 & 14 & 64 & 15 & $<5$ \\
\hline $\mathrm{Ni}$ & 196 & 70 & 15 & 43 & 35 & 72 & 235 & 534 & 208 & 80 & 12 \\
\hline Co & 59 & 50 & 45 & 39 & 43 & 83 & 56 & 46 & 55 & 48 & 9 \\
\hline $\mathrm{Cr}$ & 390 & 185 & 6 & 99 & 69 & 85 & 455 & 1085 & 172 & 425 & $<5$ \\
\hline V & 232 & 239 & 466 & 234 & 182 & 463 & 230 & 259 & 328 & 257 & 6 \\
\hline $\mathrm{Ba}$ & 624 & 609 & 112 & 632 & 52 & 18 & 105 & 23 & 26 & 124 & 89 \\
\hline $\mathrm{Sc}$ & 35 & 25 & 40 & 36 & 35 & 46 & 38 & 33 & 47 & 61 & $<5$ \\
\hline \multicolumn{12}{|c|}{ CP-MS data } \\
\hline $\mathrm{Sc}$ & 33.0 & & & & 35.9 & 41.5 & & 27.6 & & 53.8 & 0.71 \\
\hline $\mathrm{Rb}$ & 24.19 & & & & 6.79 & 1.52 & & 0.84 & & 4.00 & 1.64 \\
\hline $\mathrm{Sr}$ & 110 & & & & 90 & 92 & & 331 & & 94 & 3.9 \\
\hline $\mathrm{Y}$ & 23.6 & & & & 47.7 & 21.0 & & 21.1 & & 28.7 & 4.4 \\
\hline $\mathrm{La}$ & 12.26 & & & & 3.62 & 17.97 & & 2.96 & & 0.19 & 0.96 \\
\hline $\mathrm{Ce}$ & 30.12 & & & & 8.62 & 39.15 & & 7.75 & & 0.47 & 1.78 \\
\hline $\operatorname{Pr}$ & 4.04 & & & & 1.10 & 4.73 & & 1.78 & & 0.16 & 0.21 \\
\hline $\mathrm{Nd}$ & 19.90 & & & & 4.72 & 19.68 & & 10.09 & & 0.96 & 1.03 \\
\hline $\mathrm{Sm}$ & 4.87 & & & & 1.94 & 4.05 & & 4.15 & & 1.08 & 0.47 \\
\hline $\mathrm{Eu}$ & 1.94 & & & & 0.78 & 1.20 & & 1.31 & & 0.84 & 0.15 \\
\hline $\mathrm{Gd}$ & 5.18 & & & & 4.39 & 4.54 & & 4.88 & & 2.74 & 0.56 \\
\hline $\mathrm{Tb}$ & 0.75 & & & & 1.12 & 0.68 & & 0.78 & & 0.66 & 0.08 \\
\hline Dy & 4.49 & & & & 7.95 & 3.84 & & 4.26 & & 4.64 & 0.46 \\
\hline Ho & 0.92 & & & & 1.77 & 0.73 & & 0.80 & & 1.06 & 0.10 \\
\hline $\mathrm{Er}$ & 2.38 & & & & 4.83 & 1.99 & & 1.91 & & 3.07 & 0.26 \\
\hline $\mathrm{Tm}$ & 0.37 & & & & 0.74 & 0.28 & & 0.32 & & 0.44 & 0.04 \\
\hline $\mathrm{Yb}$ & 2.35 & & & & 4.57 & 1.73 & & 1.72 & & 3.25 & 0.24 \\
\hline $\mathrm{Lu}$ & 0.39 & & & & 0.70 & 0.28 & & 0.28 & & 0.50 & 0.04 \\
\hline $\mathrm{Pb}$ & 1.70 & & & & 1.58 & 3.54 & & 23.37 & & 15.99 & 0.64 \\
\hline Th & 1.14 & & & & 1.11 & 4.19 & & 0.41 & & 0.07 & 2.77 \\
\hline $\mathrm{U}$ & 0.28 & & & & 0.34 & 0.87 & & 0.19 & & 0.03 & 0.88 \\
\hline
\end{tabular}


Table 5.1 continued

\begin{tabular}{|c|c|c|c|c|c|c|c|}
\hline \multirow{2}{*}{$\begin{array}{c}\text { Locality } \\
\text { Sample }\end{array}$} & \multicolumn{6}{|c|}{ Other localities in the SDT } & \multirow{2}{*}{$\begin{array}{c}\text { Gneiss in the SDT } \\
\text { DB24 }\end{array}$} \\
\hline & DB-MF-1 & DB20 & DB21 & DB23 & DB25 & DB26A & \\
\hline $\mathrm{SiO}_{2}$ & 48.50 & 48.30 & 45.70 & 44.70 & 44.80 & 48.10 & 71.40 \\
\hline $\mathrm{TiO}_{2}$ & 1.04 & 3.25 & 4.88 & 2.18 & 3.12 & 0.73 & 0.47 \\
\hline $\mathrm{Al}_{2} \mathrm{O}_{3}$ & 17.60 & 13.40 & 13.20 & 14.80 & 15.30 & 15.10 & 13.20 \\
\hline $\mathrm{FeO}$ & 9.61 & 12.21 & 13.81 & 16.17 & 14.26 & 9.01 & 2.01 \\
\hline $\mathrm{Fe}_{2} \mathrm{O}_{3}$ & 2.06 & 5.07 & 5.26 & 4.22 & 3.29 & 0.79 & 0.98 \\
\hline $\mathrm{MnO}$ & 0.19 & 0.28 & 0.32 & 0.34 & 0.32 & 0.17 & 0.08 \\
\hline $\mathrm{MgO}$ & 6.93 & 3.91 & 3.63 & 4.37 & 3.41 & 8.61 & 1.50 \\
\hline $\mathrm{CaO}$ & 11.03 & 7.67 & 8.02 & 8.28 & 9.76 & 12.40 & 2.67 \\
\hline $\mathrm{Na}_{2} \mathrm{O}$ & 2.27 & 2.48 & 1.95 & 2.38 & 2.18 & 2.44 & 4.60 \\
\hline $\mathrm{K}_{2} \mathrm{O}$ & 0.03 & 0.71 & 0.26 & 0.33 & 1.04 & 0.41 & 1.32 \\
\hline $\mathrm{P}_{2} \mathrm{O}_{5}$ & 0.25 & 1.20 & 1.61 & 0.59 & 1.02 & 0.09 & 0.09 \\
\hline $\mathrm{H}_{2} \mathrm{O}$ & 0.14 & 1.13 & 0.79 & 0.70 & 0.91 & 0.59 & 1.18 \\
\hline $\mathrm{C}$ & 0.01 & 0.04 & 0.02 & 0.09 & 0.09 & 0.33 & 0.11 \\
\hline S & $<0,01$ & 0.23 & 0.63 & 0.33 & 0.07 & 0.09 & $<0,01$ \\
\hline $\operatorname{Sum}(\%)$ & 99.67 & 99.89 & 100.08 & 99.48 & 99.57 & 98.86 & 99.60 \\
\hline \multicolumn{8}{|c|}{ Trace element (ppm) } \\
\hline \multicolumn{8}{|c|}{ XRF data } \\
\hline $\mathrm{Nb}$ & $<5$ & 21 & 23 & 12 & 14 & 6 & 9 \\
\hline $\mathrm{Zr}$ & 21 & 569 & 335 & 614 & 150 & 54 & 160 \\
\hline $\mathrm{Y}$ & 10 & 49 & 49 & 57 & 36 & 21 & 25 \\
\hline $\mathrm{Sr}$ & 343 & 239 & 279 & 135 & 126 & 141 & 378 \\
\hline $\mathrm{Ga}$ & 18 & 22 & 16 & 19 & 23 & 19 & 17 \\
\hline $\mathrm{Zn}$ & 100 & 153 & 136 & 163 & 143 & 67 & 54 \\
\hline $\mathrm{Cu}$ & 66 & 37 & 131 & 62 & 42 & 205 & 6 \\
\hline $\mathrm{Ni}$ & 52 & 8 & $<5$ & 10 & 8 & 119 & 13 \\
\hline $\mathrm{Co}$ & 44 & 38 & 50 & 36 & 28 & 51 & 11 \\
\hline $\mathrm{Cr}$ & 127 & 47 & 6 & 20 & 28 & 201 & 24 \\
\hline $\mathrm{V}$ & 323 & 82 & 66 & 69 & 57 & 245 & 56 \\
\hline $\mathrm{Ba}$ & 13 & 123 & 67 & 81 & 173 & 154 & 614 \\
\hline $\mathrm{Sc}$ & 38 & 32 & 29 & 27 & 41 & 45 & 7 \\
\hline \multicolumn{8}{|c|}{ ICP-MS data } \\
\hline $\mathrm{Sc}$ & 33.0 & & 30.14 & 31.9 & & & 5.8 \\
\hline $\mathrm{Rb}$ & 1.03 & & 7.40 & 10.09 & & & 13.36 \\
\hline $\mathrm{Sr}$ & 308 & & 265.80 & 134 & & & 256 \\
\hline $\mathrm{Y}$ & 9.5 & & 44.96 & 51.7 & & & 14.7 \\
\hline $\mathrm{La}$ & 4.21 & & 52.41 & 23.63 & & & 35.68 \\
\hline $\mathrm{Ce}$ & 9.61 & & 119.02 & 56.35 & & & 74.42 \\
\hline $\operatorname{Pr}$ & 1.29 & & 15.32 & 7.39 & & & 7.71 \\
\hline $\mathrm{Nd}$ & 6.52 & & 66.72 & 34.16 & & & 29.21 \\
\hline $\mathrm{Sm}$ & 1.73 & & 11.73 & 6.91 & & & 4.65 \\
\hline $\mathrm{Eu}$ & 0.84 & & 3.97 & 2.41 & & & 1.37 \\
\hline $\mathrm{Gd}$ & 1.76 & & 12.91 & 8.72 & & & 4.55 \\
\hline $\mathrm{Tb}$ & 0.33 & & 1.70 & 1.53 & & & 0.54 \\
\hline Dy & 1.74 & & 8.82 & 9.76 & & & 2.80 \\
\hline Ho & 0.37 & & 1.66 & 1.91 & & & 0.55 \\
\hline $\mathrm{Er}$ & 1.04 & & 4.34 & 5.39 & & & 1.76 \\
\hline $\mathrm{T} \mathrm{m}$ & 0.17 & & 0.60 & 0.70 & & & 0.26 \\
\hline $\mathrm{Yb}$ & 1.03 & & 3.16 & 4.38 & & & 1.85 \\
\hline $\mathrm{Lu}$ & 0.15 & & 0.49 & 0.64 & & & 0.29 \\
\hline $\mathrm{Pb}$ & 1.17 & & 6.36 & 3.01 & & & 9.53 \\
\hline $\mathrm{Th}$ & 0.61 & & 7.89 & 3.99 & & & 6.68 \\
\hline $\mathrm{U}$ & 0.18 & & 1.01 & 0.45 & & & 0.86 \\
\hline
\end{tabular}




\subsubsection{Transition metals}

Concentrations of the transition metals $\mathrm{Sc}, \mathrm{Ti}, \mathrm{V}, \mathrm{Cr}$ and $\mathrm{Ni}$ are very variable in the investigated samples. High contents of $\mathrm{Ni}$ and $\mathrm{Cr}$ in some samples, like eclogites in Bixiling and ultramafic rocks in Shima, may be ascribed to their cumulate origin. The transition metal abundances shown in Fig. 5.5 are normalized to primitive mantle (Sun 1982). Eclogites from Shuanghe, Shima, Lidu, Raobazhai and other localities in South Dabie Shan, as well as granulite from Yanzihe and jadeite quartzite from Shuanghe, show marked negative $\mathrm{Cr}$ and $\mathrm{Ni}$ anomalies compared to primitive mantle, whereas eclogite and garnet peridotite from Bixiling and garnet peridotite from Shima have $\mathrm{Cr}$ and $\mathrm{Ni}$ contents that are only slightly lower or close to primitive mantle values. Ti content of all samples, except granulite from Yanzihe, is several times or one order of magnitude higher than primitive mantle. Abundances of $\mathrm{Mn}, \mathrm{Fe}, \mathrm{Cr}, \mathrm{Zn}$ in all samples are more or less the same as primitive mantle values.

\subsubsection{Spider diagrams}

Spider diagrams (Fig. 5.6) of trace elements normalized to primitive mantle (PM) demonstrate a heterogeneous distribution for the investigated samples. Abundances range from several to tens times primitive mantle for $\mathrm{Zr}$, $\mathrm{Ti}$ and $\mathrm{Y}$. The mobility of $\mathrm{Rb}, \mathrm{Ba}$ and $\mathrm{K}$ during retrograde metamorphism can be observed in the spider diagrams for the eclogite from Lidu and the retrograded eclogite from Bixiling compared to the unretrograded eclogite samples from Shima and Bixiling. Most eclogites and associated garnet peridotite (DB10) from Bixiling have patterns similar to enriched mid-ocean ridge basalt (E-MORB) or least contaminated continental flood basalt (CFB) (Fig. 5.6a). A spidergram for CFB derived from Seifert et al. (1997) indicates that the CFB pattern is similar to E-MORB, except for a slight Ba enrichment and a slight $\mathrm{P}$ depletion. However, eclogites show prounounced negative anomalies in $\mathrm{Nb}$ and $\mathrm{P}$, and positive anomalies in $\mathrm{Pb}$ and $\mathrm{Sr}$. Slight positive $\mathrm{Eu}$ anomalies, which are attributed to cumulus plagioclase, are observed for all samples. Both negative and positive Ti anomalies are found. The retrograded eclogite (DB02) shows very distinct differences in the incompatible elements $(\mathrm{Rb}, \mathrm{Ba}$ and $\mathrm{K})$; this could result from retrograde metamorphism. Very similar $\mathrm{Zr}$ and $\mathrm{Nb}$ contents suggest that all the investigated samples from Bixiling, including the garnet peridotite and the retrograded eclogite, formed from the same magmatic source. Samples from Shima were collected from three individual outcrops; all three samples have very distinct positive anomalies in $\mathrm{U}, \mathrm{Nb}$ and $\mathrm{Pb}$, and negative anomalies in $\mathrm{K}$ (Fig. 5.6b). Samples from Shuanghe included both eclogites in marble (DB29) and in gneiss (DB32) and jadeite quartzite (DB31); eclogites show positive anomalies in $\mathrm{U}, \mathrm{Nb}, \mathrm{Pb}$ and $\mathrm{Zr}$ and negative anomalies in $\mathrm{K}$ 

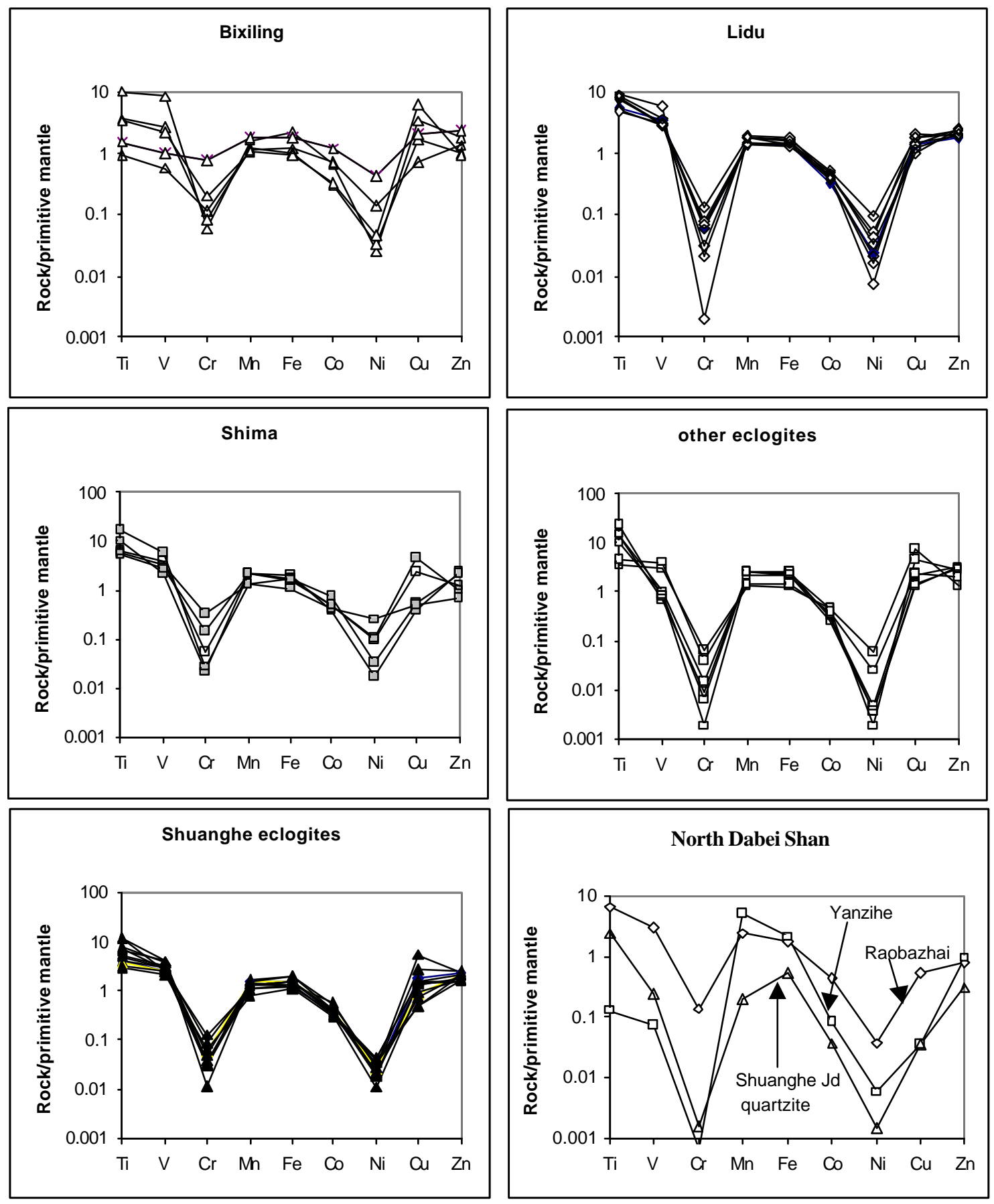

Fig. 5.5. Primitive mantle normalized transition metal abundances of the metamorphic rocks from Dabie Shan.

and $\mathrm{Eu}$, whereas jadeite quartzite shows positive anomalies in $\mathrm{U}$ and $\operatorname{Pr}$ and negative anomalies in $\mathrm{K}, \mathrm{Pb}, \mathrm{Sr}$ and $\mathrm{Ti}$ (Fig. 5.6c); the low $\mathrm{K}, \mathrm{Rb}, \mathrm{Ba}$ and $\mathrm{Sr}$ concentrations in jadeite quartzite are very comparable with albitized siltstones (Liou et al., 1997). Eclogite from Lidu display positive anomalies in $\mathrm{Ba}, \mathrm{K}$, and $\mathrm{Pb}$, and negative anomalies in $\mathrm{U}, \mathrm{Nb}$ and $\mathrm{Ti}$ (Fig. 5.6d); furthermore, weak positive Eu anomalies are observed. 

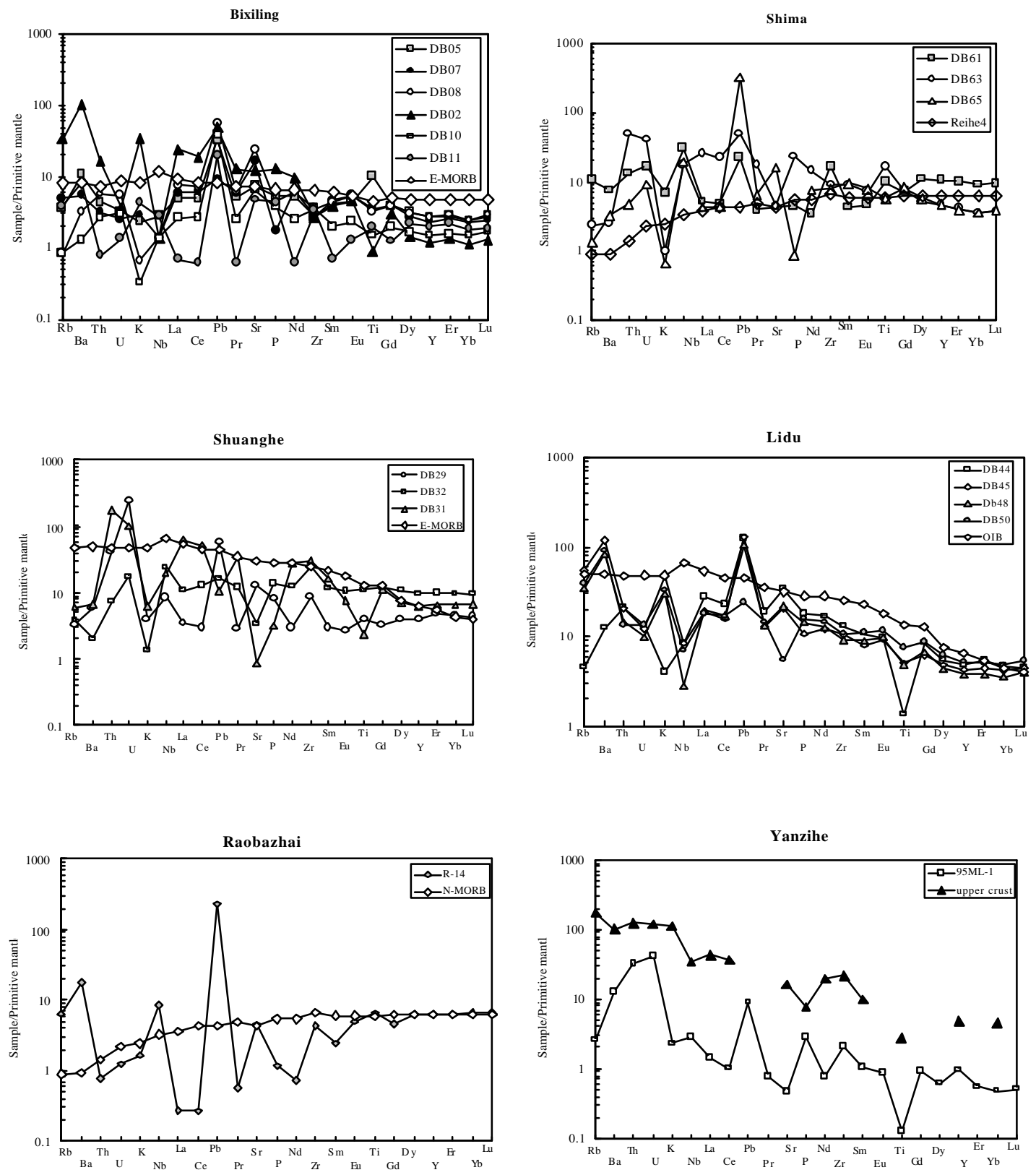

Fig. 5.6. Primitive mantle normalized trace element variation diagram for the rocks from Dabie Shan. The nrimitive mantle values used here are from Sun and McDonough (1989).

For samples from the North Dabie complex, eclogite from Raobazhai shows positive anomalies in $\mathrm{Nb}, \mathrm{Pb}, \mathrm{Zr}$ and $\mathrm{Ti}$, and negative anomalies in $\mathrm{Th}, \mathrm{Pr}, \mathrm{Nd}$ (Fig. 5.6). Granulite from Yanzihe shows trace element patterns similar to upper continental crust (Weaver and Tarney, 1984), but with lower concentrations (Fig. 5.6f). 


\subsubsection{Rare-earth elements (REE)}

REE concentration data are presented in Table 5.1, and REE patterns normalized to primitive mantle are plotted in Fig. 5.7. The investigated samples show compalicated REE patterns. The majority is characterized by a relative light REE (LREE) enrichment that is commonly observed in continental basalts, including most samples from Bixiling, Lidu and other eclogite localities in the SDT. Garnet peridotite associated eclogite in Bixiling, eclogites from Shuanghe and granulite from Yanzihe have flat REE patterns. Exceptions are a few samples from Bixiling (DB11), Shima (DB61) and Raobazhai (R-14), showing LREE-depleted MORB-type patterns. The complicated REE patterns of eclogites in Bixiling might result from their cumulate origin (Zhang et al., 1995; Chavagnac and Jahn, 1996). It is interesting to note that the eclogite from Rabaozhai is strongly LREE depleted (Fig. 5.7e), but has a negative initial $\varepsilon \mathrm{Nd}$ value of -2.9 (Table 5.1). This is interpreted to be caused by a loss of LREE before peak metamorphism (Xiao et al., 2001). The MORB-type REE pattern for the eclogite in Shima (DB61), which is relatively fresh without any obvious retrograde signatures, is difficult to interpret, as no other isotopic data exist so far. The jadeite quartzite sample has a REE pattern similar to fine-grained sediments from the upper continental crust (Taylor and McLennan, 1985).
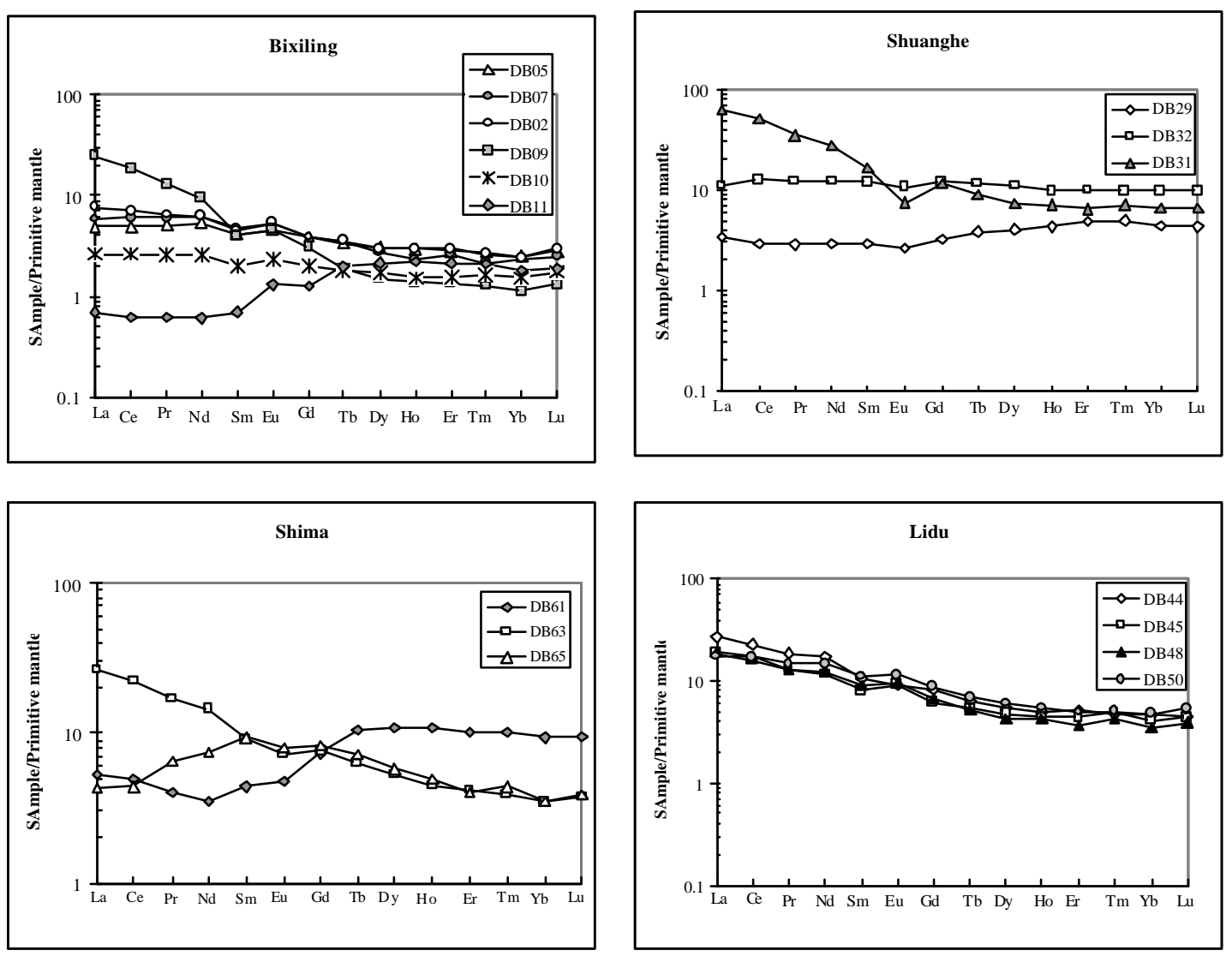

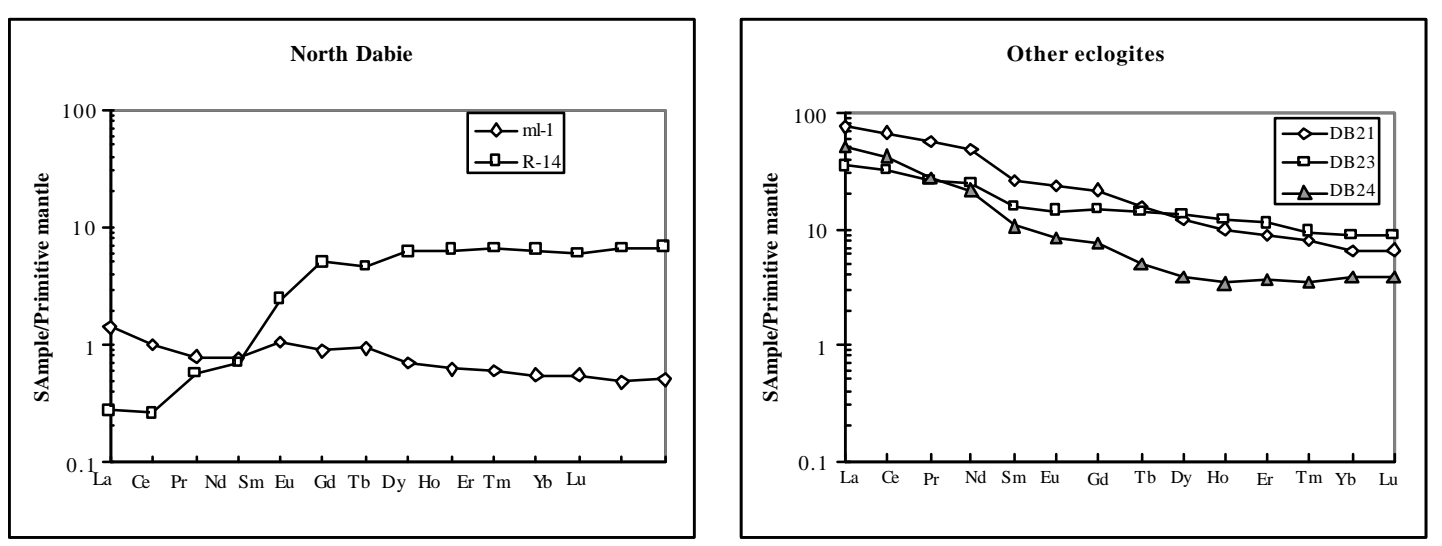

Fig. 5.7. Rare earth element patterns for investigated samples from Dabie Shan. The primitive mantle values used here are from Sun and McDonough (1989).

\subsection{Mineral REE distributions}

Trace element distributions in minerals have been determined by laser-based ICPMS analysis mainly on eclogite-facies minerals such as garnet and clinopyroxene As omphacitic pyroxene and garnet are dominant minerals during eclogite-facies metamorphism, knowledge of REE distributions of the two minerals is of fundamental importance in determining REE compositions during peak metamorphism of the studied samples.

\subsubsection{The UHP eclogite of Bixiling}

Figure 5.8 illustrates REE patterns normalized to primitive mantle (Sun and McDonough, 1989) for individual clinopyroxenes and garnets in eclogites and associated garnet peridotite. Data for four specimens, including retrograded eclogite (DB02), fresh eclogite (DB05), kyanite-rich eclogite (DB07) and garnet peridotite (DB10), are presented.

All garnets from Bixiling are characterized by LREE-depleted patterns with primitivemantle $\mathrm{La} / \mathrm{Yb}$ ratios between 0.003 and 0.07 . Rising steeply from La to $\mathrm{Sm}$, the $\mathrm{REE}_{\mathrm{N}}$ patterns become almost flat (Subscript $\mathrm{N}$ indicates normalization to the primitive mantle composition). As has been mentioned earlier, two generations of garnet can be observed in the retrograded eclogites: one is dark-red garnet, the other is a fine-grained later crystallized orange-yellow garnet (see also Xiao et al., 2000). Their patterns show very different REE concentrations: the dark-red garnet has much higher $\Sigma$ REE concentrations than the later crystallized orange-yellow one (Fig. 5.8). As it is generally believed that heavy REE (HREE) are not mobile during fluidmineral interactions, such a difference must reflect the effects of recrystallization. 

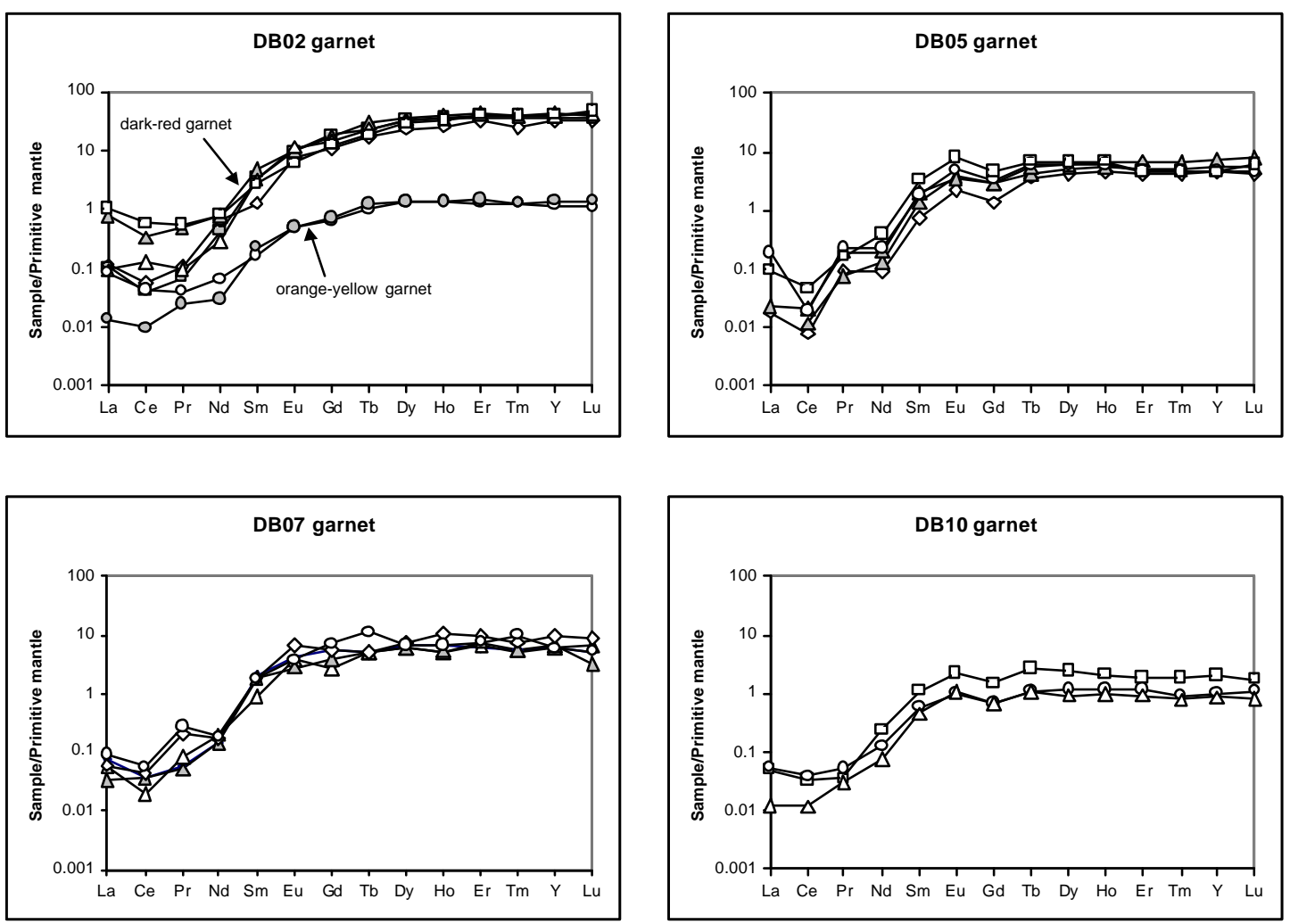

Fig. 5.8. REE concentrations in garnets from eclogites and peridotite in Bixiling
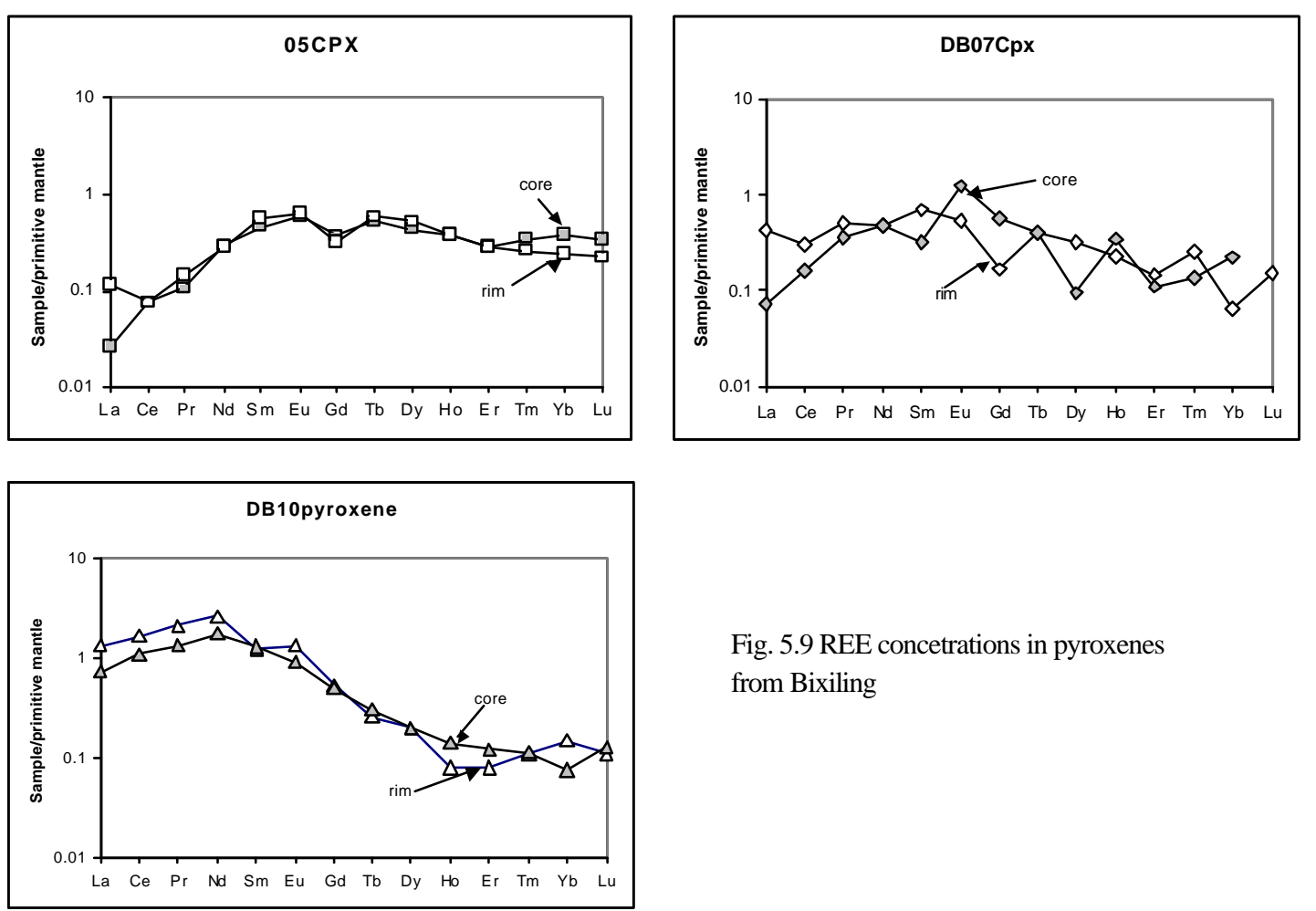

Fig. 5.9 REE concetrations in pyroxenes from Bixiling 
The primitive mantle-normalized REE patterns of the clinopyroxenes do not differ significantly being enriched in middle REE (Fig. 5.9). Omphacite in retrograded eclogite was not analyzed because it is mostly replaced by symplectite.

\subsubsection{The coesite-bearing eclogite from Shima}

Primitive mantle normalized REE patterns of garnet and omphacite from Shima are shown in Fig. 5.10a and b, respectively. Consistent with the petrological observation that this sample is relatively "fresh" with no obvious alterations, the REEN patterns of garnets do not show too much differences, even for the mobile element "La". Although they are LREE depleted, with a steep increase from $\mathrm{La}$ to $\mathrm{Sm}$, the normalized values decrease slightly from Dy to $\mathrm{Lu}$. Profile analyses indicate that the garnet core has slightly higher REE compositions than its rim (Fig. 5.10a).
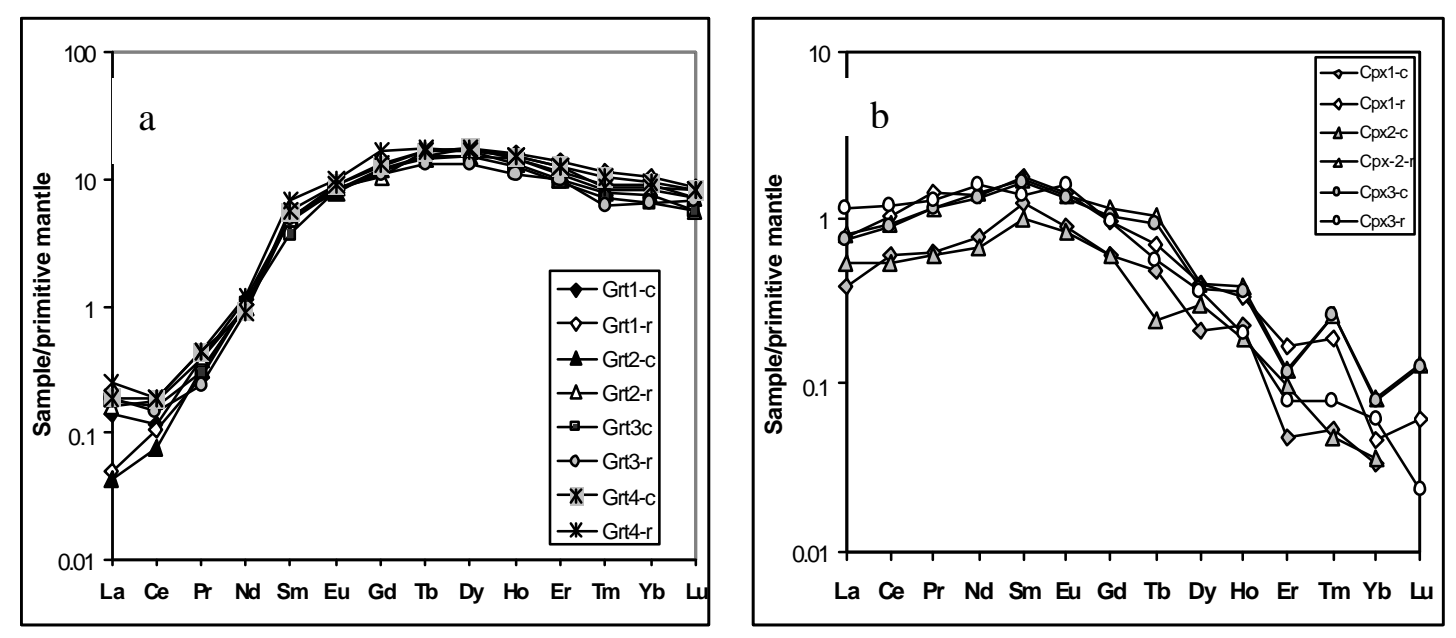

Fig. 5.10 REE concentrations in garnet (a) and omphacite (b) from Shima

In contrast to garnet, omphacite has higher REE concentrations in the rim compared to the core, with LREE concentrations similar to that of the primitive mantle and strong HREE depletion (Fig. 5.10b).

\subsubsection{UHP jadeite quartzite in Shuanghe}

Compared to garnets in the other samples, garnet in jadeite quartzite from Shuanghe has the highest REE concentrations, showing a REE pattern up to twenty times of primitive mantle abundances for LREE and about two hundred times for almost flat HREE (Fig. 5.11a). Garnets are too small for checking if they are REE zoned. 

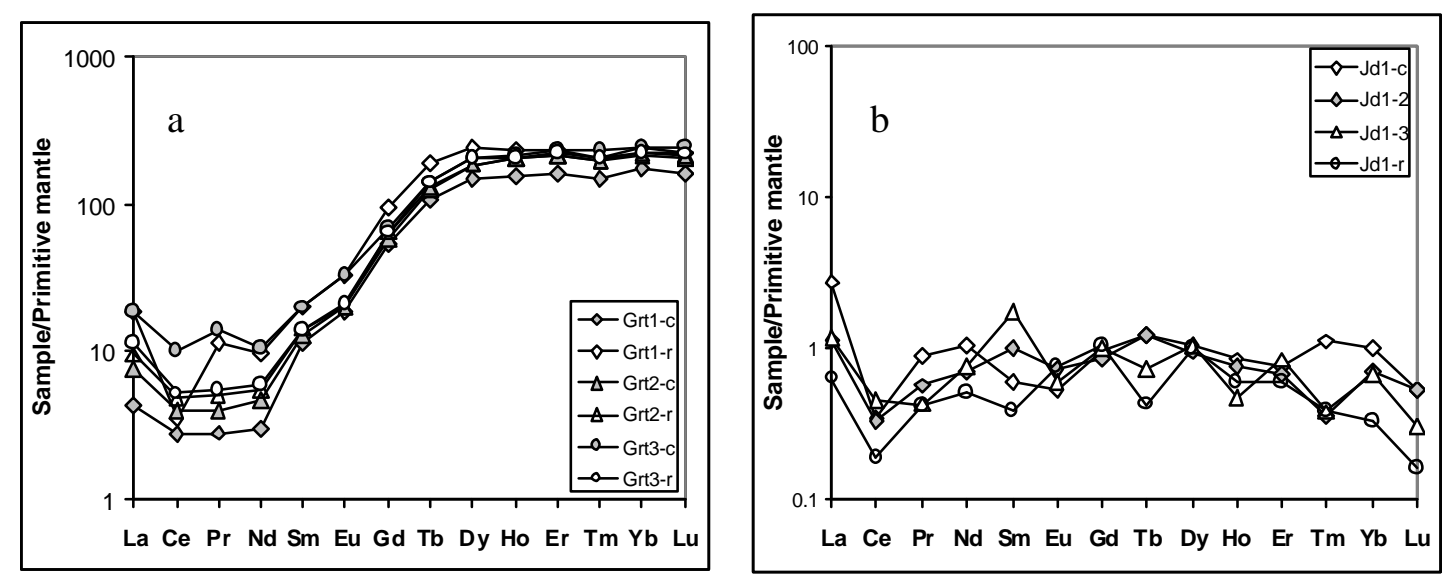

Fig. 5.11 REE concentrations in garnet (a) and jadeite (b)

from Shuanghe

Jadeite has almost flat REE patterns with abundances around $1 \mathrm{x}$ primitive mantle. Profile analyses for jadeite grains revealed slightly higher REE concentrations in the core than in the rim (Fig. 5.11b). Kelyphitic coronas of jadeites (consisting of an inner layer of oligoclase + minor fibrous amphibole and an outer layer of albite + fine-grained aegirine-augite, Liou et al., 1997) show similar primitive mantle-normalized REE patterns as jadeite, indicating no significant exotic fluid has been involved during retrograde metamorphism.

\subsubsection{Garnet in the Lidu eclogite}

As presented in Fig. 4.9, garnet crystals in Lidu eclogite display systematic major elements zonations. Fig. 5.12 shows the primitive mantle-normalized REE pattern of a 9mmwide garnet porphyroblast with complicate major element zonations (see Fig. 4.7) and oxygen isotope zonations (see oxygen isotope section). In contrast to garnets in the other studied samples, REE concentrations of garnets in the Lidu eclogite are higher in the rim than in the core. As will be shown later (section 7.1), this probably resulted from mineratfluid interactions during garnet growth. In other words, the fluid system of the eclogite in Lidu was open during garnet growth, agreeing with the major element analyses and the oxygen isotope study. 


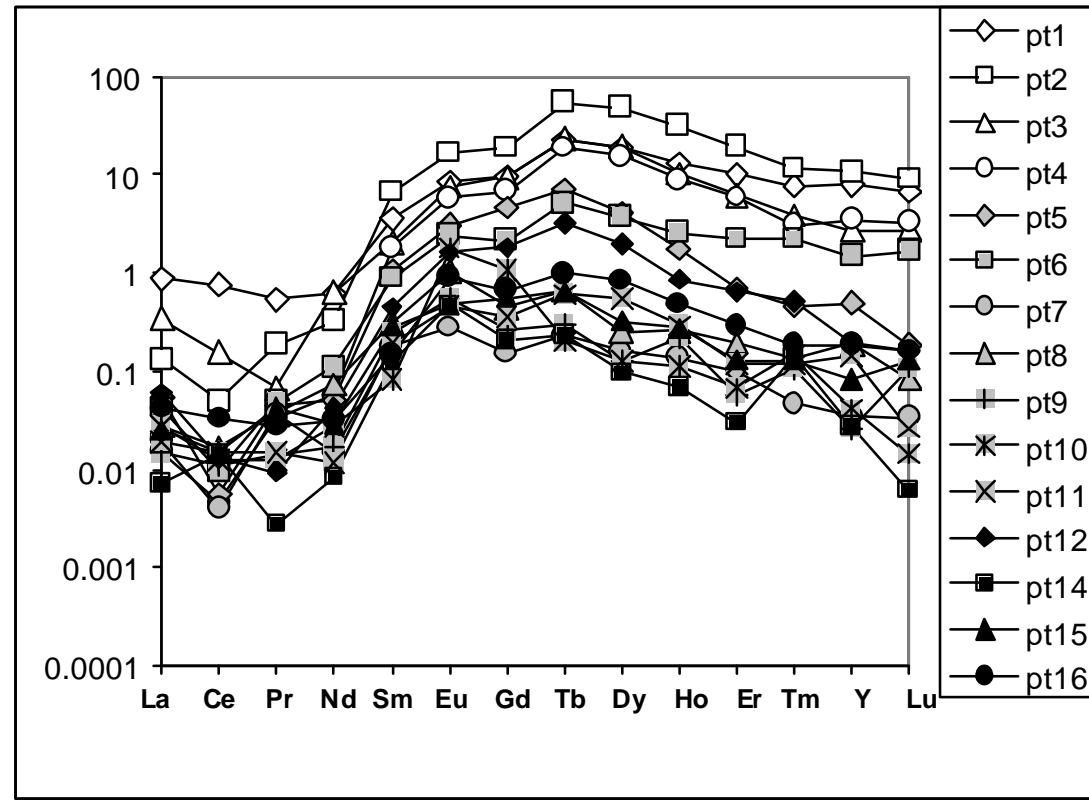

Fig. 5. 12. Primitive mantle-normalized REE abundances in a garnet porphyroblast from the Lidu eclogite. Profile position see Fig. 7.4.

\subsubsection{The Raobazhai eclogites}

REE analyses of garnet and pyroxene from Raobazhai show the well-known fact that garnet is rich in heavy rare earth elements (HREE), whereas pyroxene is rich in middle REEs (Fig. 5.13a, b). REE concentrations of garnet are slightly higher in the cores than in the rims. This zoning is somewhat bell shaped and roughly parallel to the bell-shaped major element zoning (Fig. 4.10). The concentrations of most REEs decrease toward the garnet rims, suggesting the existence of a fractionation process. This also indicates that there was no significant fluid-rock interaction during garnet growth, which is consistent with the oxygen isotope data (see below). However, the very rim of the garnet (point 1) has chondritenormalized light rare earth element (LREE) values that are about 10 times higher than those of the next measured spot (point 2) and of the core signatures (Fig. 5.13a), although the heavy REE signatures are comparable. This probably resulted from fluid-rock interaction after the garnet growth. Pyroxene has convex-upward shaped chondrite-normalized patterns (Fig. 5.13b), which is a common feature in clinopyroxene from mantle xenoliths (Song \& Frey, 1989). HREE/LREE ratios vary from 10 to 30 , with the highest ratios in the cores and intermediate regions of the grain (Fig. 5.13c). 

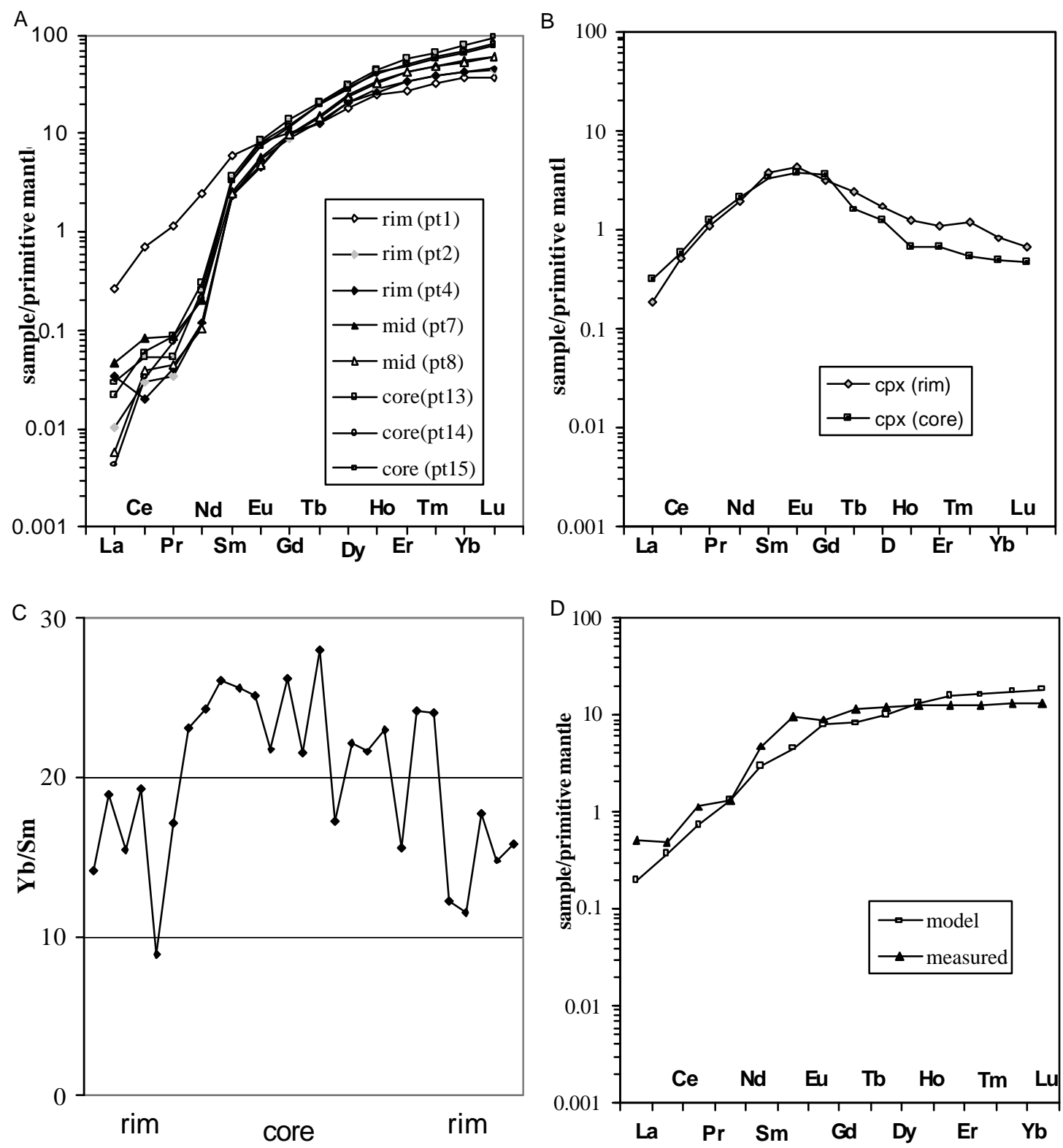

Fig. 5.13. REE concentrations within garnet (a), pyroxene (b) and whole rock (d) from the Raobazhai eclogite. (c) HREE/LREE profile of the same garnet as in (a) (rim to rim). Locations of points in (a) are depicted in Fig. 7.5.

\subsubsection{The granulite in Yanzihe}

As described above, three texturally different garnets can be observed in the Yanzihe granulite: one is garnet with homogeneous major element compositions; the second type is garnet with micro veins composed of Cl-rich amphiboles (see section 4.5 for details); the third is garnet as inclusions in quartz. The primitive mantle-normalized REE patterns for the three types of garnets are shown in Fig. 5.14. 
All three garnets display LREE depleted and HREE enriched patterns with slightly negative $\mathrm{Eu}$ anomalies. However, the garnet with homogeneous major element compositions shows more or less the same LREE abundances and a slight decrease of HREE from core to rim (Fig. 5.14a), whereas garnet with Cl-rich amphibole veins shows much higher LREE but similar HREE concentrations in portions close to the amphibole veins compared to the portions away from the veins (Fig. 5.14b). This agrees with the oxygen isotope mapping of the same grain, which revealed lower $\delta^{18} \mathrm{O}$ values for the portions near the vein (see oxygen isotope section). Garnet inclusions in quartz have more or less homogeneous REE patterns (Fig. 5.14c)
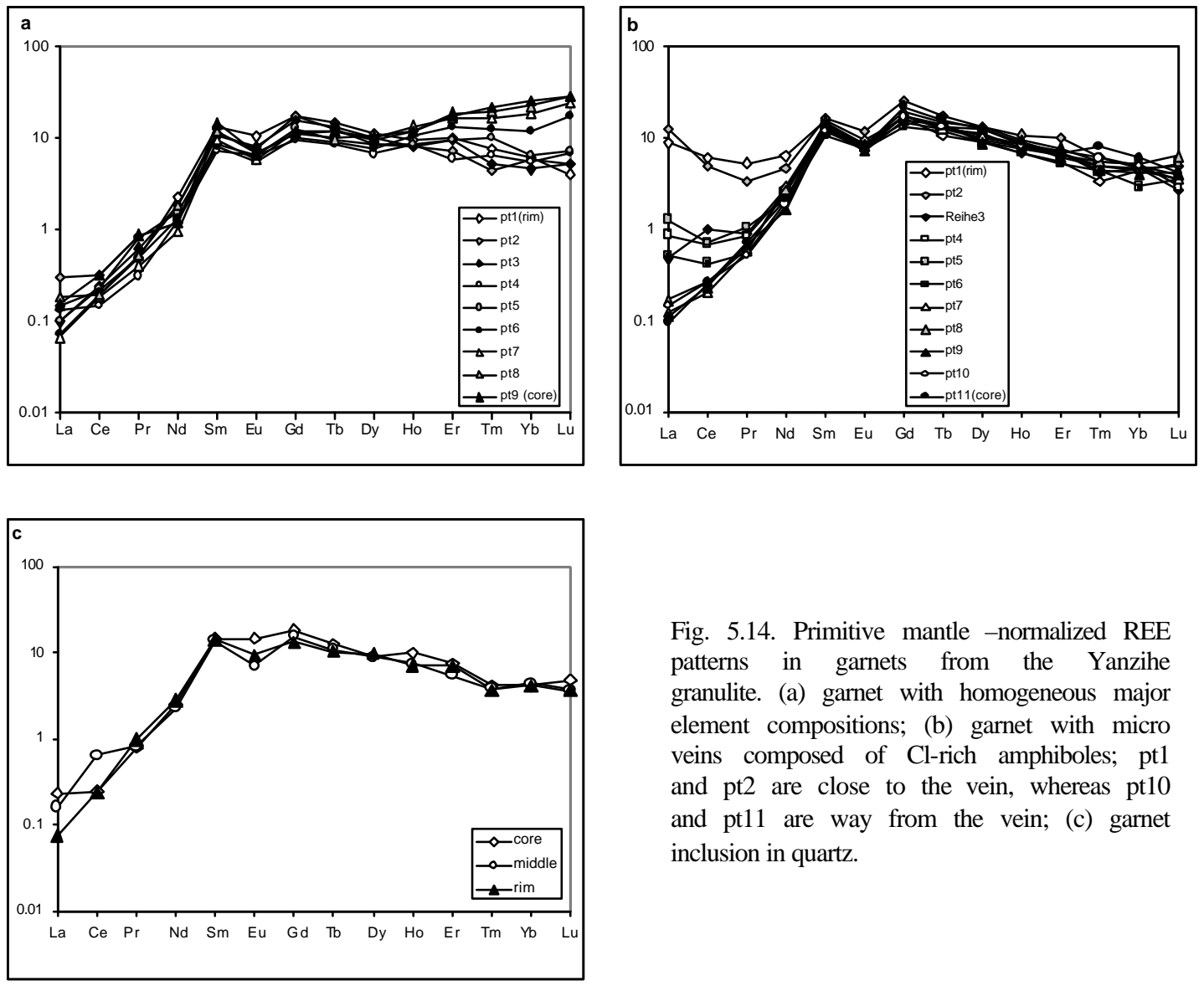

Fig. 5.14. Primitive mantle -normalized REE patterns in garnets from the Yanzihe granulite. (a) garnet with homogeneous major element compositions; (b) garnet with micro veins composed of Cl-rich amphiboles; pt1 and $\mathrm{pt} 2$ are close to the vein, whereas pt10 and pt11 are way from the vein; (c) garnet inclusion in quartz.

\subsection{Tectonic settings and nature of the protoliths}

As shown above, the protoliths of the studied eclogites are mainly basalts. It has been suggested that $\mathrm{Zr}$ and $\mathrm{Nb}$ are the most stable and near-immobile elements during eclogitefacies metamorphism (Becker et al., 2000); in the discrimination diagram for basalts based on Ti-Zr variations (Fig. 5.15, after Pearce, 1982), most eclogites fall into the volcanic-arc field, and only a few samples plot in the within-plate field; the fact that some samples from Bixiling 
exceed the entire volcanic field supports their cumulate origin. The plot of $\mathrm{Zr} / \mathrm{Nb} \mathrm{vs}$. $\mathrm{Nb}$ (Fig. 5.16) shows that all the studied eclogite samples have lower $\mathrm{Zr} / \mathrm{Nb}$ ratios compared to MORB independent of $\mathrm{Nb}$ concentrations, indicative of island-arc basalts (McCulloch and Gamble, 1991). Figure 5.17 shows that the studied eclogite samples have highly variable $\mathrm{Ti} / \mathrm{V}$ ratios ranging from 5 to 450; this range encompass all fields of basaltic rocks; however, most samples plot in the island arc tholetiite field, and clearly do not support an oceanic origin for the precursor rocks. Furthermore, low $\mathrm{Cr}$ and $\mathrm{Ni}$ in eclogites (except those in Bixiling) also contribute evidence for an island arc origin (Taylor, 1977).

The major and trace elements, and REE characteristics presented above indicate that the protoliths of the studied rocks from Dabie Shan have complex origins, and that these rocks derive from heterogeneous sources which are further modified by fractional crystallization. As mentioned above, eclogites from Bixiling and Lidu have negative $\mathrm{Nb}$ anomalies, whereas eclogites from Shuanghe, Shima and Raobazhai have positive $\mathrm{Nb}$ anomalies (Fig. 5.6). A negative $\mathrm{Nb}$ anomaly is the most characteristic feature of subduction zone volcanic rocks or typical continental crust. A recent study of Huang et al. (2000) has demonstrated that basaltic rocks with positive $\mathrm{Nb}$ anomalies were derived from within-plate processes with high $\mathrm{Nb} / \mathrm{Ta}$, whereas those with negative $\mathrm{Nb}$ anomalies were derived from a mantle which has been modified by subduction processes. Eu anomalies are small for most investigated samples. Eclogites from Bixiling and Lidu show slight positive $\mathrm{Eu}$ anomalies, whereas those from Shima and Shuanghe display slight negative $\mathrm{Eu}$ anomalies. The only exception is the jadeite quartzite from Shuanghe, in which a distinct negative $\mathrm{Eu}$ anomaly can be observed (Fig. 5.6c). Mantlederived rocks usually have no $\mathrm{Eu}$ anomalies, which means that primary mantle additions into the crust should induce no changes. In contrast, post-Archean sediments are well established as being characterized by significant negative Eu anomalies.

Based on the present data and previous studies from Dabie Shan area (Zhang Q. et al., 1995; Chavagnac and Jahn, 1996; You et al., 1996; Zhang R. et al., 1996; Liou et al., 1998; Jahn et al., 1998, 1999b; Xiao et al., 2001), the geochemical characteristics of the studied samples can be summarized as follows:

(1) Eclogites and associated garnet peridotite from Bixiling and the eclogite from Raobazhai have geochemical characteristics of a mantle origin. The low $\mathrm{SiO}_{2}$ and high $\mathrm{Ti}$ and $\mathrm{V}$ contents in some samples from Bixiling are evidence of a cumulate origin. The negative $\mathrm{Nb}$ and slight positive $\mathrm{Eu}$ anomalies in the Bixiling eclogites are indicative of crustal contamination in the pre-metamorphic magmatic evolution (see also Chavagnac and Jahn, 1996), whereas eclogite in Raobazhai was less changed when induced into the crust. 
(2) Low $\mathrm{Zr} / \mathrm{Nb}$ ratios, $\mathrm{Cr}$ and $\mathrm{Ni}$ contents, REE patterns and tectonic environment discriminating diagrams suggest an island arc volcanic origin for most eclogites in the Dabie Shan area. Thus, the protoliths of the eclogites in Shima, Shuanghe and Lidu are more likely island arc volcanic rocks. Relatively young Tethys oceanic rocks have not been clearly identified in the studied samples.

(3) The jadeite quartzite in Shuanghe has distinctly low $\mathrm{K}, \mathrm{Rb}, \mathrm{Ba}$ and $\mathrm{Sr}$ contents that are very comparable with albitized siltstone (Kalsbeek, 1992). Its REE pattern is similar to that of upper continental sediments (Taylor and McLennan, 1985). The very distinctive negative Eu anomaly is strong evidence for its sedimentary origin.

(4) Granulite in Yanzihe has trace element patterns similar to upper continental crust (Weaver and Tarney, 1984) (Fig. 5.6f). However, the much lower trace element and REE concentrations, and alkalis contents indicate its protolith cannot be of upper crustal origin. It is possible that the granulite was partialy melted during metamorphism. Its negative initial $\varepsilon_{\mathrm{Nd}}$ value of -6 (Table 5.1) is also indicative for such a partial melt process.

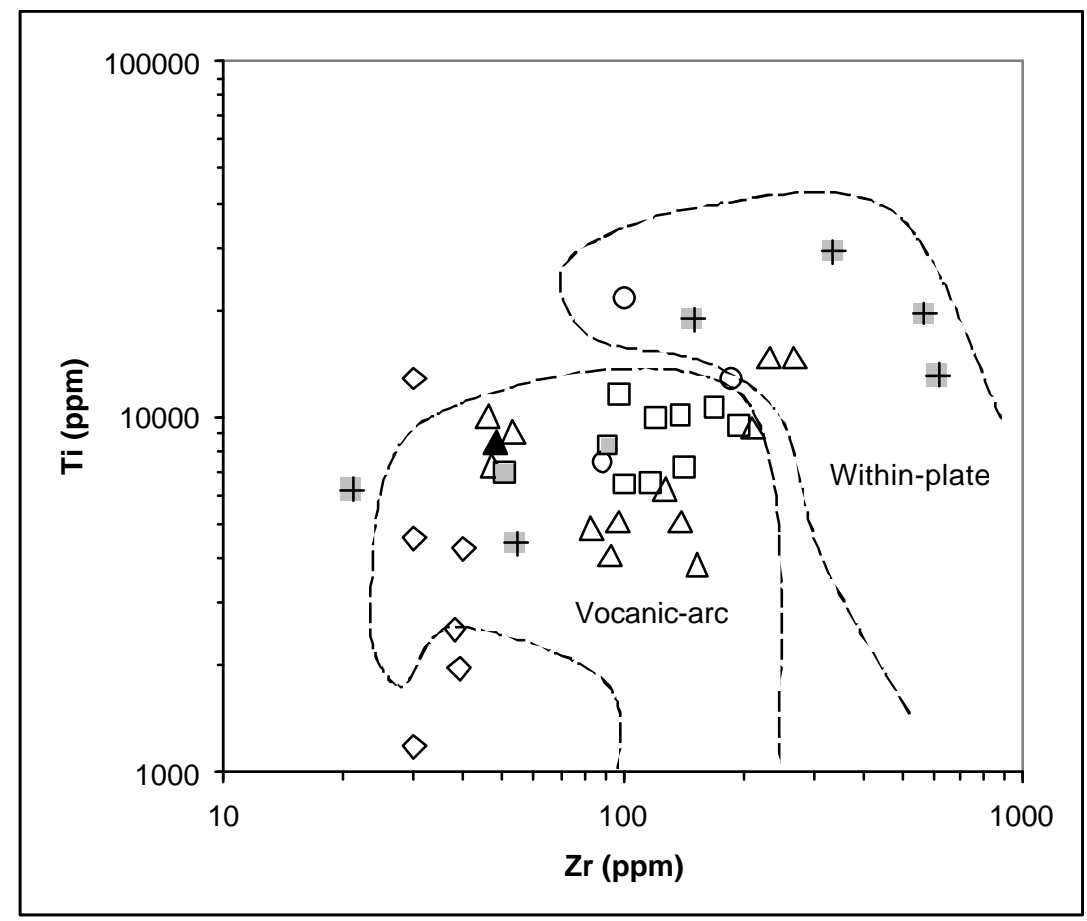

Fig. 5.15. Discrimination diagram for investigated samples based on $\mathrm{Ti}-\mathrm{Zr}$ variations of whole rock (after Pearce, 1982). Symbols as in Fig. 5.2. 


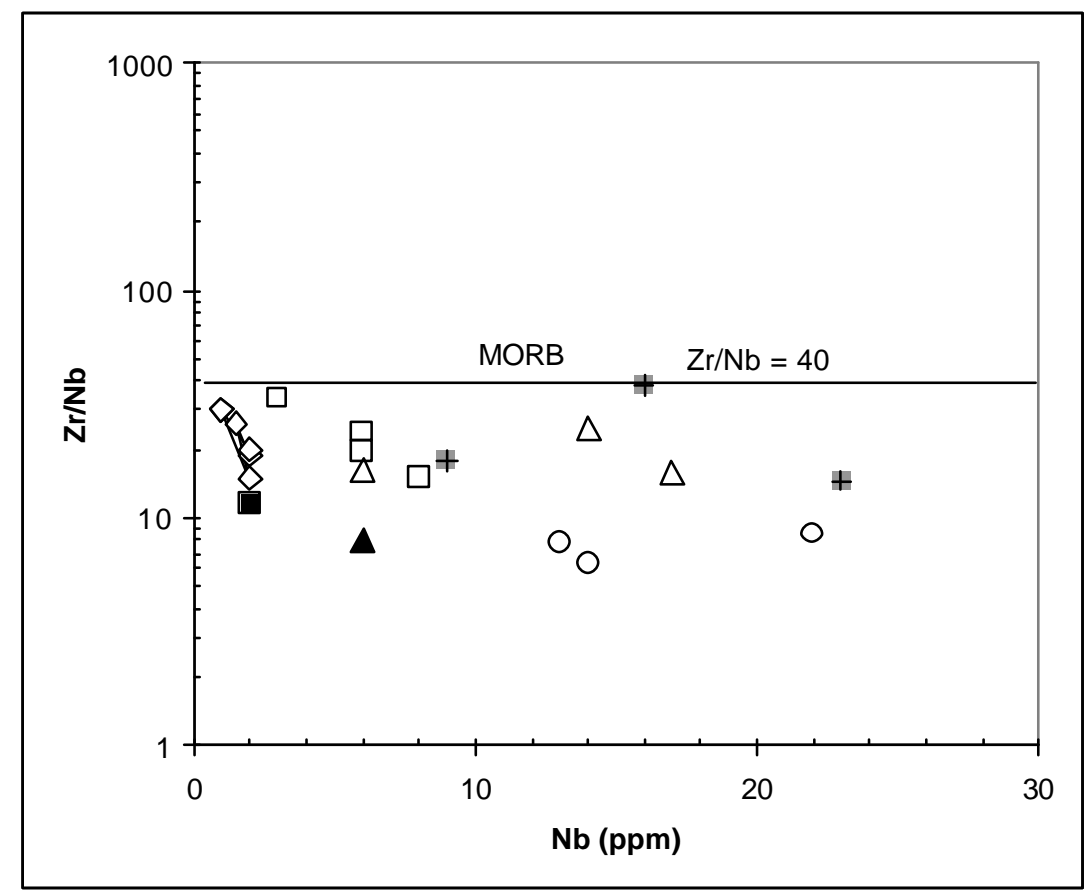

Fig. 5.16. $\mathrm{Zr} / \mathrm{Nb}-\mathrm{Nb}$ diagram for investigated samples (after McCulloch and Gamble, 1991). Symbols as in Fig.5.2.

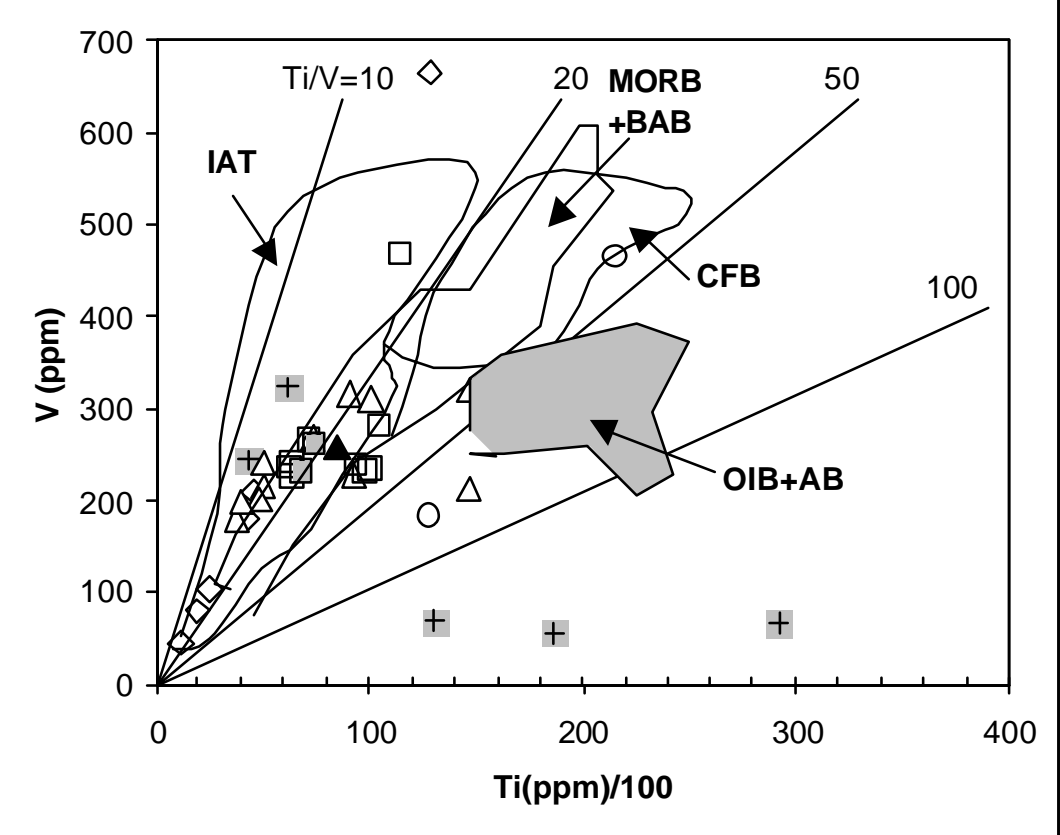

Fig. 5.17. Ti-V discrimination diagram shows that the investigated samples are widely scattered, exceeding the entire field of basaltic rocks (after Shervais, 1982). IAT, island arc tholiite; MORB, mid-ocean ridge basalt; BABB, backarc basin basalt, $\mathrm{CFB}$, continental flood basalt; OIB, ocean island basalt; $\mathrm{AB}$, alkaline basalt. Symbols as in Fig. 5.2. 


\section{Chapter 6. FLUID INCLUSION STUDIES}

Fluid inclusions provide the only available samples of metamorphic fluids and information on composition and physical properties of the fluid phase(s) involved in ultrahigh-pressure metamorphism. By selecting fluid inclusions for analysis after detailed microscopic examination and using careful routines of data analysis to ensure the representative nature of the inclusions, it has been possible to obtain important information about the nature of the fluid.

According to textural criteria and compositions, 6 types of fluid inclusions were identified in ultra-high and high pressure metamorphic rocks from the Dabie Shan. These types include low-salinity aqueous inclusions, high salinity aqueous inclusions( $\mathrm{S}_{\text {halite }} \mathrm{LV}$ or $\left.\mathrm{S}_{\text {halite }} \mathrm{L}\right), \mathrm{Ca}^{2+}\left(\mathrm{Mg}^{2+}\right)$-rich brines, $\mathrm{N}_{2}$-bearing aqueous inclusions, carbonic inclusions and $\mathrm{H}_{2} \mathrm{O}-\mathrm{CO}_{2}$ inclusions. The fluid inclusions usually occur in quartz, garnet, omphacite and kyanite. Normally they are $<25 \mu \mathrm{m}$ in diameter, and rarely up to $40 \mu \mathrm{m}$. The distributions and occurrences of different fluid inclusions types for the study areas in the SDT and NDC are summarized in Table 6.1.

\subsection{Fluid inclusions of the UHP eclogite from Bixiling}

Fluid inclusions have been found in quartz blebs in kyanite, omphacite, kyanite and matrix quartz in the eclogite from Bixiling. They range in size from $2 \mu \mathrm{m}$ to $40 \mu \mathrm{m}$, with a mode between 5 and $20 \mu \mathrm{m}$. Garnet is commonly devoid of fluid inclusions, with few exceptions, which contain isolated $1-2 \mu \mathrm{m}$ fluid inclusions associated with mineral inclusions.

Based on textural criteria, five types of fluid inclusions were distinguished. These types also reflect different fluid compositions and densities (Table 6.1):

(1) Ca-rich brine inclusions in quartz blebs in kyanite (Fig. 6.1a) are isolated or randomly distributed. Most of them are 3-phase $\left(\mathrm{LVS}_{\text {halite }}\right)$ and show rounded or negative crystal morphologies with fill degrees of about $80 \mathrm{vol} \%$. These fluid inclusions represent the oldest recognizable generation of fluid inclusions and must have been formed during prograde metamorphism. They mostly do not show any phase-transition during cooling, but show a granular texture between -65 and $-75{ }^{\circ} \mathrm{C}$ on subsequent warming, interpreted as a transition from metastable non-crystalline to a crystalline state. This phenomenon hides a clear observation of the eutectic point $\left(T_{e}\right)$. We assume that the $T_{e}$ is slightly higher than this 
Table 6.1 Distribution of fluid inclusions in the metamorphic rocks from Dabie Shan. +++ high abundance, ++ medium abundance,

+ low abundance, - very few inclusions.

\begin{tabular}{|c|c|c|c|c|c|c|c|c|}
\hline & Locality & Host mineral & $\begin{array}{l}\text { Low-salinity } \\
\text { aqueous } \\
\text { inclusion }\end{array}$ & $\begin{array}{l}\text { High-salinity } \\
\text { aqueous } \\
\text { inclusion }\end{array}$ & $\begin{array}{l}\mathrm{Ca}^{2+}\left(\mathrm{Mg}^{2+}\right)- \\
\text { rich brines }\end{array}$ & $\begin{array}{l}\mathrm{N}_{2} \text {-bearing } \\
\text { aqueous } \\
\text { inclusion }\end{array}$ & $\begin{array}{l}\text { Carbonic } \\
\text { inclusion }\end{array}$ & $\begin{array}{l}\mathrm{H}_{2} \mathrm{O}-\mathrm{CO}_{2} \\
\text { inclusion }\end{array}$ \\
\hline \multirow{4}{*}{ SDT } & Bixiling & Omphacite & & ++ & & & - & \\
\hline & & Matrix-Qz & +++ & ++ & & & + & \\
\hline & Shima & quartz & & ++ & & & & \\
\hline & Shuanghe & quartz & +++ & + & & & & + \\
\hline \multirow{3}{*}{ NDC } & Raobazhai & garnet & + & + & & + & +++ & + \\
\hline & Yanzihe & garnet & - & & & & +++ & +++ \\
\hline & & quartz & & & & & +++ & ++ \\
\hline
\end{tabular}




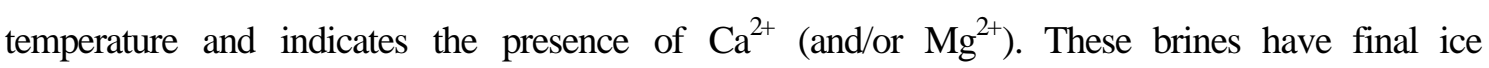
melting temperatures of $-40{ }^{\circ} \mathrm{C}$ to $-21{ }^{\circ} \mathrm{C}$. Homogenization temperatures are between $145{ }^{\circ} \mathrm{C}$ and $260{ }^{\circ} \mathrm{C}$ (Fig. 6.2a); The solid phases do not dissolve below $500{ }^{\circ} \mathrm{C}$. Rare clathrate melting between 10 and $15^{\circ} \mathrm{C}$ indicates the presence of minor $\mathrm{CO}_{2}$.

(2) Primary high-salinity aqueous inclusions $( \pm$ halite) in omphacite and in kyanite (Fig 6.1b, c) occur isolated or in groups and clusters. Some of these inclusions occur as tubes oriented parallel to the elongation of host crystals, suggesting trapping during crystal growth. Most of them are halite-bearing three-phase inclusions with a fill degree ranging from 70 to 90 vol.\%. The fact that most of these inclusions occur in the core of omphacite and kyanite grains suggests that this type of inclusions contains relic peak metamorphic fluids. Unlike brines in quartz blebs in kyanite, high-salinity fluid inclusions in omphacite and kyanite show clear freezing between -60 and $-70{ }^{\circ} \mathrm{C}$ during cooling and display eutectic temperatures between -30 and $-21{ }^{\circ} \mathrm{C}$, indicating a dominantly NaClbearing fluid. They show final ice melting temperatures of $-27{ }^{\circ} \mathrm{C}$ to $-17{ }^{\circ} \mathrm{C}$, and liquid-vapor homogenization temperatures of $97{ }^{\circ} \mathrm{C}$ to $440{ }^{\circ} \mathrm{C}$ (Fig. 6.2a). The solid phase (if any) does not dissolve before the decrepitation of the fluid inclusions at $\sim 500^{\circ} \mathrm{C}$.

(3) Intermediate to high-salinity fluid inclusions in matrix quartz have been observed in all eclogite samples. These inclusions occur isolated or in groups and clusters and possibly are also of primary origin. They are commonly single phase or two-phase (liquid-vapor) at room temperature. However, they sometimes contain a solid phase, possibly halite. The se inclusions display melting temperatures between -24 and $-10 \quad{ }^{\circ} \mathrm{C}$, and liquid-vapor homogenization temperatures from 150 to 270 (Fig 6.2a).

(4) Rare carbonic inclusions were found both in omphacite and in matrix quartz. These inclusions are monophase at room temperature. They occur isolated and as clusters and have rounded or negative crystal shapes. In some quartz grains these inclusions occur together with intermediate to high-salinity inclusions. This close textural relationship suggests simultaneous trapping of the two fluids, most probably during primary growth of the host minerals. The carbonic inclusions in omphacite display final $\mathrm{T}_{\mathrm{mCO} 2}$ around $-58.5{ }^{\circ} \mathrm{C}$ and $\mathrm{Th}$ (to liquid) between -31 and $-25{ }^{\circ} \mathrm{C}$, whereas those in coarse-grained quartz have $\mathrm{T}_{\mathrm{mCO} 2}$ of -59.5 to $-58{ }^{\circ} \mathrm{C}$ and $\mathrm{T}_{\mathrm{h}}$ (to liquid) between -17 and $-4{ }^{\circ} \mathrm{C}$ (Fig 6.2b). Their melting temperatures are indicative for additional $\mathrm{N}_{2}$ and/or $\mathrm{CH}_{4}$. 

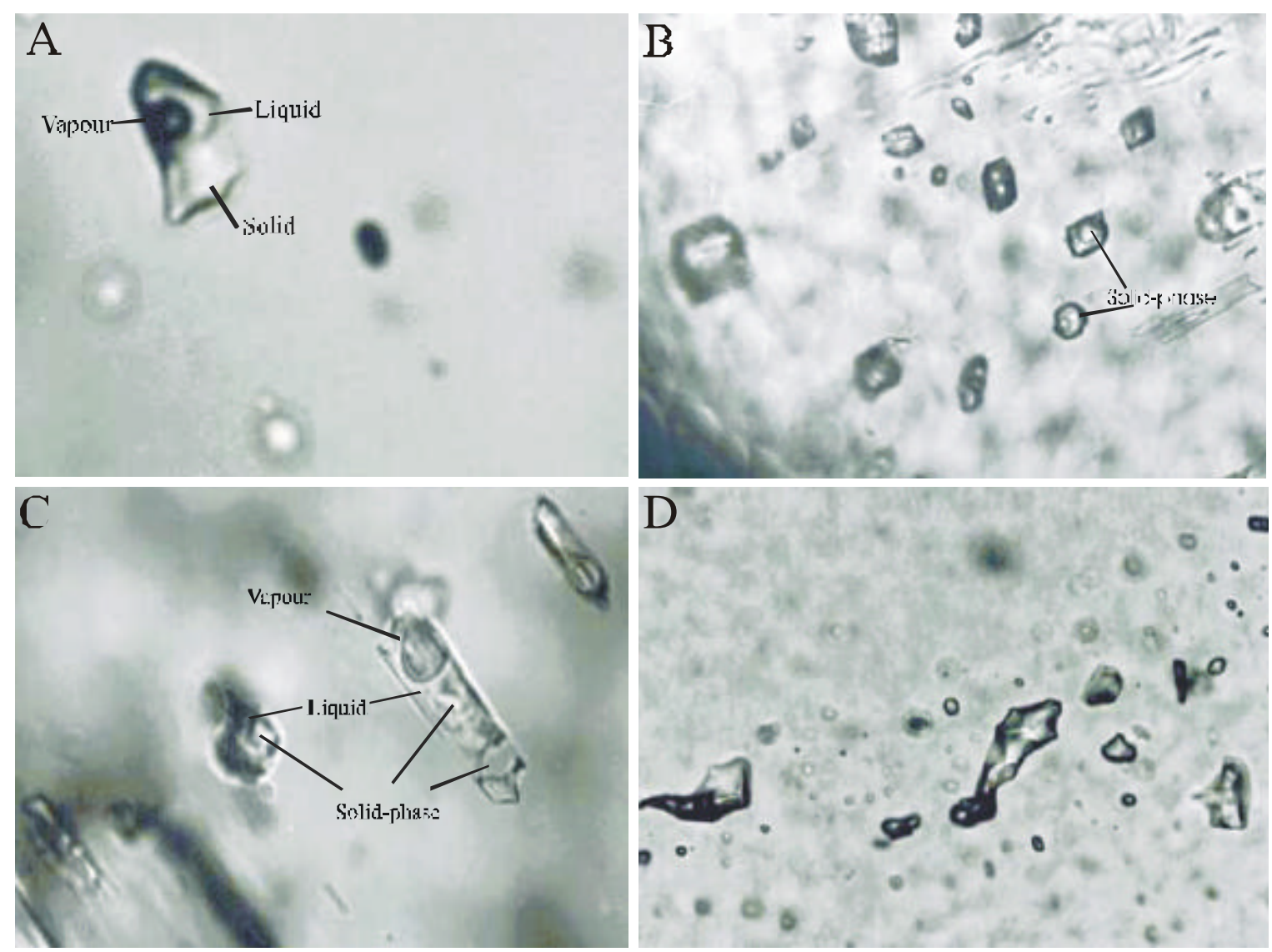

Fig. 6. 1 A-D Photomicrographs of fluid inclusions in different minerals from Bixiling. A Ca (Mg)-rich brines in quartz blebs in kyanite; B high-salinity inclusions in omphacite; $\mathrm{C}$ high-salinity inclusions in kyanite; $\mathrm{D}$ secondary low -salinity inclusions in matrix quartz of retrograded eclogite

A

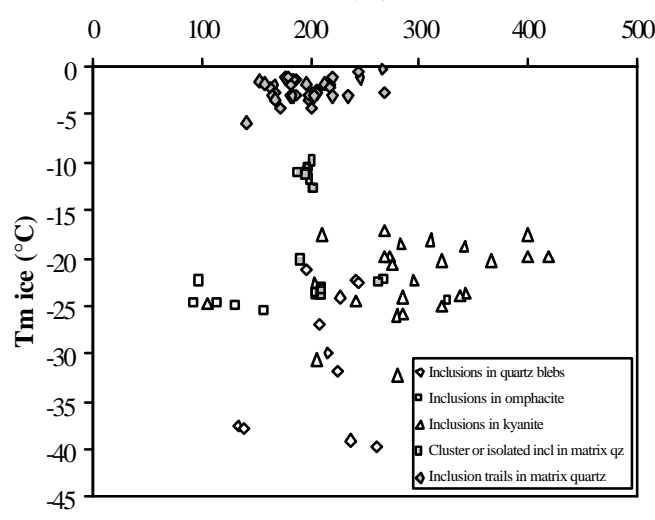

B

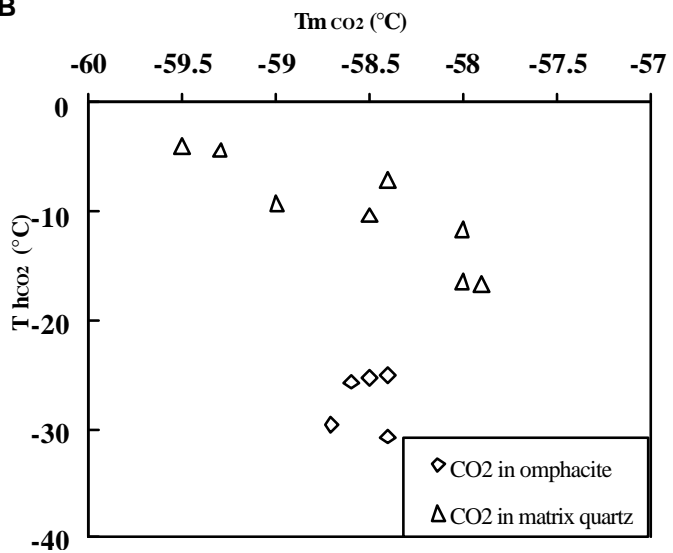

Fig. 6.2 A Microthermometric results of aqueous inclusions in the eclogite from Bixiling; B

Microthermometric results of carbonic inclusions in omphacite and matrix quartz 
(5) Secondary low-salinity aqueous (or pure water) inclusions in matrix quartz (Fig. 6.1d) are dominant in the retrograded eclogite, and are bound to healed fractures. They are assumed to represent the latest feature among the generations of fluid inclusions in the eclogite. Most of the inclusions are mono-phase, whereas some are two-phase $(\mathrm{L}+\mathrm{V})$ at room temperature with fill degrees of 80 - 95 vol\%. The majority of these secondary fluid inclusions show large variation in size and shape, but their composition is quite constant with ice melting temperatures of -6 to $0{ }^{\circ} \mathrm{C}$, corresponding to low-salinities or pure water (Fig. $6.2 a)$.

Measurable fluid inclusions in garnet peridotite have not been found. We assume that fluid inclusions in the ultramafic rocks did not survive during retrograde metamorphism.

Isochore calculations (Brown and Lamb, 1989) show that the Carich brines in quartz blebs were trapped at $56 \mathrm{kbar}$ at trapping temperature of $600{ }^{\circ} \mathrm{C}$. The isochores of primary high-salinity aqueous inclusions in omphacite and kyanite fall into the minimum P-T conditions for the eclogite-facies metamorphism $\left(\mathrm{P}=\sim 15 \mathrm{~kb}\right.$ at $\left.\mathrm{T}=700-800^{\circ} \mathrm{C}\right)$, i.e. at least $14 \mathrm{~kb}$ below the peak metamorphic pressure estimated from the stability of coesite. The lower fluid densities are probably due to late re-equilibration of the fluid inclusions. The calculated trapping conditions of the $\mathrm{CO}_{2}$ inclusions in omphacite and quartz are $6 \mathrm{~kb}$ and $4 \mathrm{~kb}$, at $700^{\circ} \mathrm{C}$, respectively. The isochores of the late low-salinity aqueous inclusions indicate maximum trapping pressure of $5 \mathrm{~kb}$ at $500{ }^{\circ}$, corresponding with late fluid inclusion formation during retrograde amphibolite metamorphism. Mismatch between pressure estimates based on mineral thermobarometry and on fluid inclusions is commonly encountered in high-grade metamorphic rocks, due to partial decrepitation by internal overpressure in fluid inclusions during uplift. Based on their recent experimental results, Schmidt et al. (1998) suggest that the mismatch is also due to the $T_{h}$ measurements under 1 atm pressure.

Fluid inclusions in different textural settings reflect trapping and remobilization of fluids at different metamorphic stages of the eclogites in Bixiling: The fluid inclusions in quartz blebs in kyanite are assumed to represent the earliest recognizable fluid and originated from prograde metamorphism. The fluid phase during the prograde stage was dominated by $\mathrm{Ca}$-(Mg)-rich brines. Although minor amounts of $\mathrm{CO}_{2}$ have been found, $\mathrm{CO}_{2}$ appeared to be not important during the prograde metamorphism, however locally present in omphacite during eclogite-facies metamorphism. Both the NaClbearing inclusions (in omphacite and kyanite) and the $\mathrm{CO}_{2}$ inclusions (in omphacite and quartz) probably originated from UHP 
conditions but may have partly leaked during uplift. The low-salinity inclusions correlate to retrograde amphibolite-facies conditions and lower.

For the high-concentration of $\mathrm{Ca}^{2+}$ in the prograde eclogite-facies, a possible explanation is the exchange of cations between plagioclase and chloride-rich fluid. The $\mathrm{Ca}: \mathrm{Na}$ activity ratio in the fluid is related to coexisting plagioclase of fixed composition based on the equilibrium:

$$
\mathrm{CaAl}_{2} \mathrm{Si}_{2} \mathrm{O}_{8}+2 \mathrm{Na}^{+}+4 \mathrm{SiO}_{2} \Leftarrow \Rightarrow 2 \mathrm{NaAlSi}_{3} \mathrm{O}_{8}+\mathrm{Ca}^{2+}
$$

With increasing salinity of the fluid during prograde metamorphism, and hence increasing $\mathrm{Na}$, the activity of $\mathrm{Ca}^{2+}$ increases with the square of the $\mathrm{Na}$ activity, so that a high-salinity brine in equilibrium with a given plagioclase will have a high $\mathrm{Ca}$ :Na ratio.

In summary, the fluid inclusions show that during the metamorphic evolution of the coesite-bearing eclogite from Bixiling, the fluids evolved from highly concentrated $\mathrm{Ca}$ dominated brines $\pm \mathrm{CO}_{2}$ (prograde metamorphism), towards Na-dominated solutions (peak metamorphism) and to low salinity aqueous fluids during retrograde uplift. A possible explanation for the decreasing salinities with time during retrograde metamorphism is the increasing admixture of pure water derived from the surrounding quartzofeldspathic gneisses. The role of $\mathrm{CO}_{2}$, locally present as inclusions in matrix quartz and in omphacite, appears to be limited.

\subsection{Fluid inclusions in the eclogite from Shima}

In Shima, high salinity aqueous inclusions in quartz have been observed as the only fluid type. The textures suggest that they are of primary origin and were trapped during the growth of their host mineral (Fig. 6.3). As quartz is a stable phase at eclogite-facies metamorphism, these high-salinity inclusions are assumed to represent the compositions of the fluid phase during peak metamorphism of the Shima eclogite. The absence of secondary inclusions corresponds to the fact that the studied eclogite from Shima is less altered, and also indicates that the formation of the low-salinity fluid inclusions in the other localities are related to retrograde metamorphism.

Microthermometric results show that the fluid inclusions have final ice melting temperatures between -22 and $-11{ }^{\circ} \mathrm{C}$, with a maximum around $-12{ }^{\circ} \mathrm{C}$, corresponding to high salinity. The fluid inclusions homogenize to the liquid phase in the temperature range from 160 to $320{ }^{\circ} \mathrm{C}$ (Fig. 6.4). Like in Bixiling, isochore calculations give minimum P-T conditions for the eclogite-facies metamorphism, with $\mathrm{P}=\sim 14 \mathrm{kbar}$ at temperatures of $\sim 800$ ${ }^{\circ} \mathrm{C}$. 


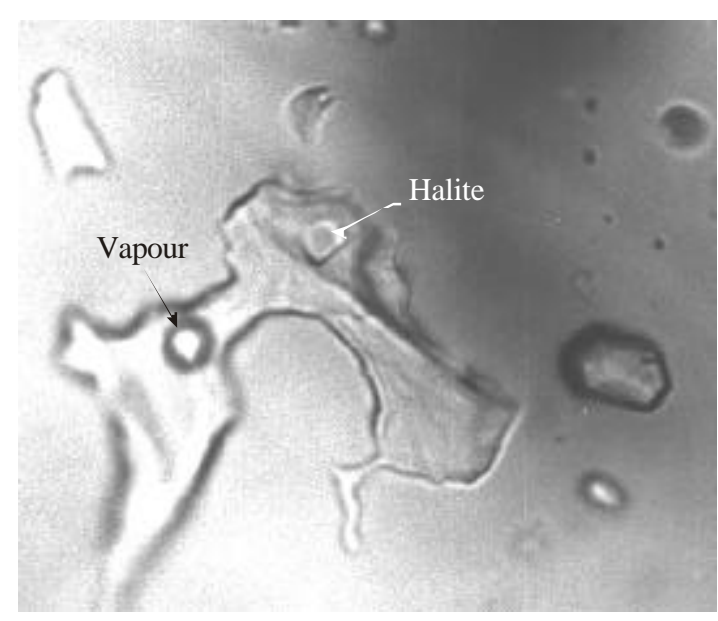

Fig. 6.3. Photomicrograph of high salinity inclusions in quartz from Shima.

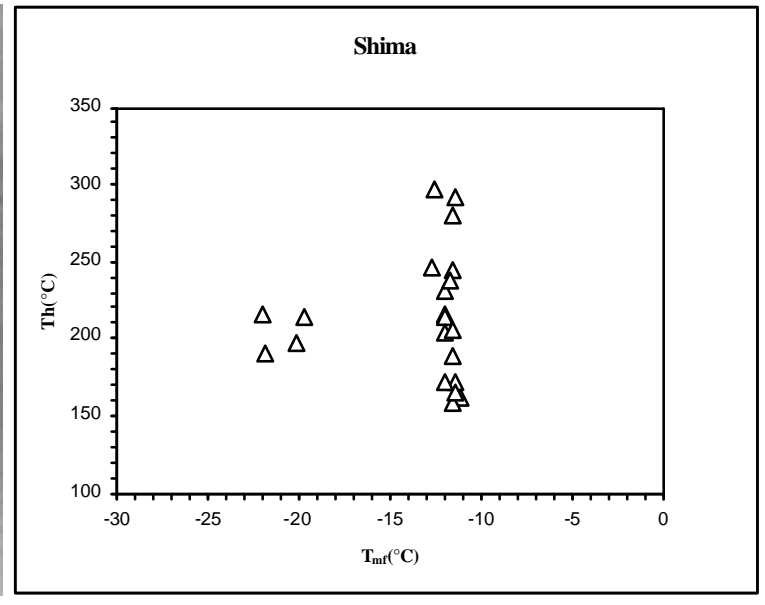

Fig. 6.4. Microthermometric results of fluid inclusions in quartz from Shima

\subsection{Fluid inclusions in the jadeite quartzite from Shuanghe}

Jadeite and garnet in jadeite quartzite from Shuanghe are most generally devoid of fluid inclusions. In one jadeite grain, few two-phase aqueous inclusions have been observed. However, they were apparently modified. The two measurable inclusions (about $4 \mu$ in size, others are too small to be measured) display final ice melting temperature around $-3{ }^{\circ} \mathrm{C}$ and homogenization temperatures between 150 and $165{ }^{\circ} \mathrm{C}$, corresponding to low-salinity fluids or almost pure water.

The highest abundance and most complex inclusion patterns occur in quartz. Both carbonic and aqueous inclusions were observed in matrix quartz. Based on textural criteria, three generations of aqueous inclusions in quartz can be related to distinct metamorphic stages:

(1) Low-salinity aqueous inclusions in quartz blebs in jadeite. Most occur isolated and as clusters, and have rounded or negative crystal shapes. They are monophase or 2 phase $(\mathrm{L}+$ V) inclusions with fill degrees of 80 to 95 vol\%. Textural evidence suggests that they were trapped before jadeite formation. In other words, these inclusions were trapped during prograde metamorphism, and therefore probably represent the fluid compositions before the peak of metamorphism. Microthermometric measurements give final ice melting temperatures of -6 to $0{ }^{\circ} \mathrm{C}$, and homogenization temperatures between 140 and $190{ }^{\circ} \mathrm{C}$ (Fig. 6.6a).

(2) Low-salinity inclusions in coarse-grained quartz occur as isolated or scattered in groups and clusters, and are possibly primary (Fig. 6.5A). The groups and clusters are often 
cut by trails of fluid inclusions. These inclusions are either monophase or 2-phase with fill degrees of 80 to $90 \mathrm{vol} \%$ at room temperature. They have final ice melting temperatures between -10 and $0{ }^{\circ} \mathrm{C}$, and homogenization temperatures between 150 to $230{ }^{\circ} \mathrm{C}$ (Fig. 6.6A).

(3) Secondary aqueous inclusions in coarse-grained quartz, mostly occur in healed fractures. From textural criteria, they represent a later feature than the primary inclusions.
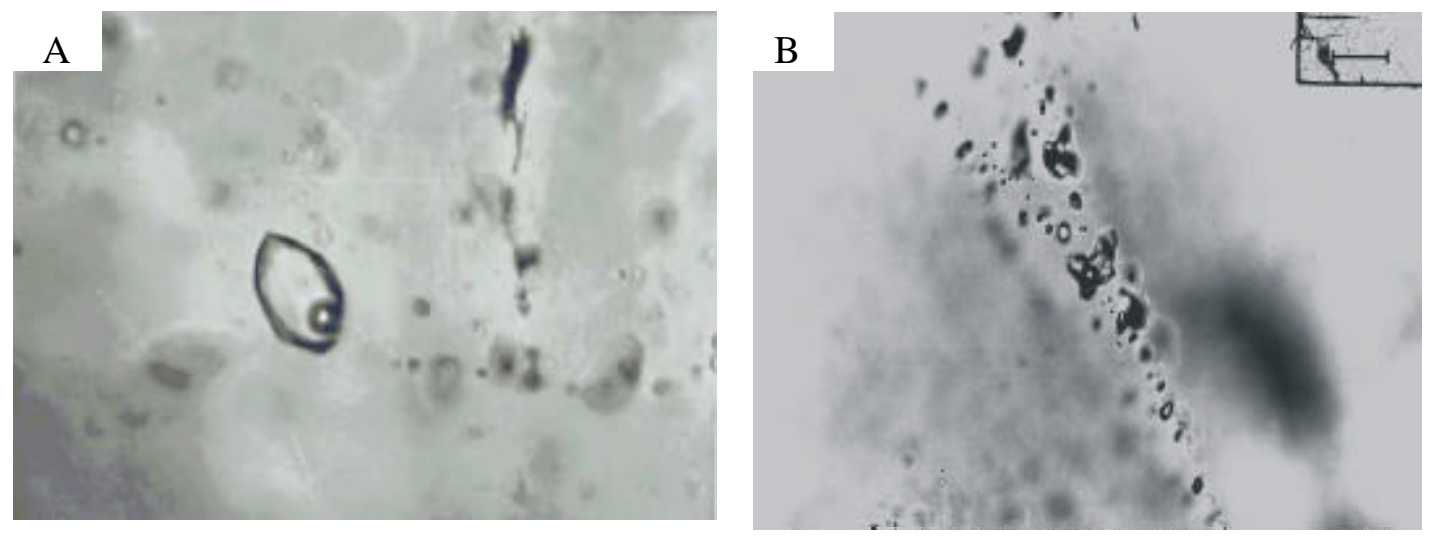

Fig. 6.5 Photomicrographs of fluid inclusions in the Jadeite quartzite from Shuanghe. A Primary inclusion with negative crystal morphology in quartz; B Secondary aqueous inclusion trail in quartz.

They show melting temperatures of -3 to $0{ }^{\circ} \mathrm{C}$ and homogenization temperatures of 126 to $180{ }^{\circ} \mathrm{C}$ (Fig. 6.6A).
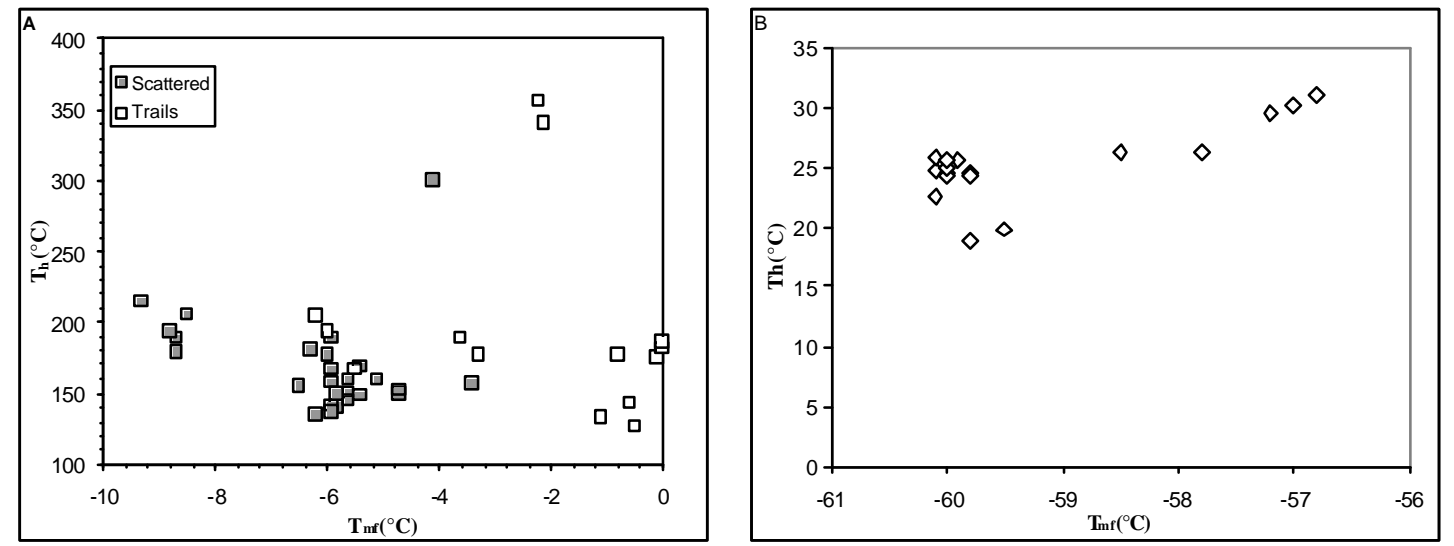

Fig. 6.6. Microthermometric results of fluid inclusions in the jadeite quartzite from Shuanghe. (A) aqueous inclusions; (B) Secondary carbonic inclusions.

Besides the aqueous inclusions, inclusions with various proportions of $\mathrm{CO}_{2}$ have been also observed in coarse-grained quartz. Their $\mathrm{CO}_{2}$ contents may vary from 10 to $>90 \mathrm{vol} \%$ (no visible water). They occur in microfractures, indicating that the fluid inclusions formed relatively late. Textures suggest that these inclusions were trapped simultaneously with the 
secondary aqueous inclusions in quartz, probably during the late stage of metamorphic evolution. The $\mathrm{CO}_{2}$ in the $\mathrm{H}_{2} \mathrm{O}-\mathrm{CO}_{2}$ inclusions has melting temperatures between -59.5 and $56.8{ }^{\circ} \mathrm{C}$, homogenezation temperatures between 10 and $31{ }^{\circ} \mathrm{C}$, and clathrate melting temperatures of 3 to $10{ }^{\circ} \mathrm{C}$. Carbonic inclusions (without visible water) show melting temperatures around $-60{ }^{\circ} \mathrm{C}$ and homogenization temperatures between 24 and $26{ }^{\circ} \mathrm{C}$. The melting temperatures are indicative for small amounts of additional $\mathrm{N}_{2}$ and/or $\mathrm{CH}_{4}$ (Fig. 6.6b).

In contrast to the coesite-bearing jadeite quartzite from Dora-Maira massif, Western Alps, in which $\mathrm{CO}_{2}$ inclusions are absent (Philippot et al., 1995), jadeite quartzite in Dabie Shan involved $\mathrm{CO}_{2}$-bearing fluids during retrograde metamorphism. Unlike the UHP eclogites from Bixiling and Shima, in which high-salinity inclusions represent the fluid compositions of the peak metamorphism, fluids during peak metamorphism of the jadeite quartzite are lowsalinity solutions (rare inclusions have final melting temperature of about $-10^{\circ} \mathrm{C}$ ).

In summary, during the metamorphic evolution of jadeite quartzite in Shuanghe fluids evolved from low-salinity solutions during prograde metamorphism, and perhaps as well during peak and early retrograde stages, towards mixed fluids of $\mathrm{CO}_{2}$ and $\mathrm{H}_{2} \mathrm{O}$ during late retrograde metamorphism.

\subsection{Fluid inclusions in the eclogite from Lidu}

Fluid inclusions in the 'cold' eclogites from Dabie Shan (Lidu and Huanliangting) are not as abundant as in UHP eclogites. In the eclogite from Lidu, low -salinity fluid inclusions in matrix quartz were found. Most of other minerals are commonly devoid of fluid inclusions. These low salinity inclusions have oblate, roundish, negative crystal shapes, or irregular morphologies; most occur in healed fracture.

Microthermometric results show that fluid inclusions in the eclogite from Lidu display final ice melting temperatures between -10 and $0^{\circ} \mathrm{C}$, corresponding to low salinity. They have homogenization temperatures between 130 and $360^{\circ} \mathrm{C}$ (Fig. 6.7). Isochore calculations indicate that the highest density of the low-salinity inclusions in matrix quartz correlates to 8 kbar at $600{ }^{\circ} \mathrm{C}$ and $4.5 \mathrm{kbar}$ at $400{ }^{\circ} \mathrm{C}$. The occurrence of fluid inclusions in healed fractures imply that the low salinity fluids were trapped during retrograde metamorphism. 


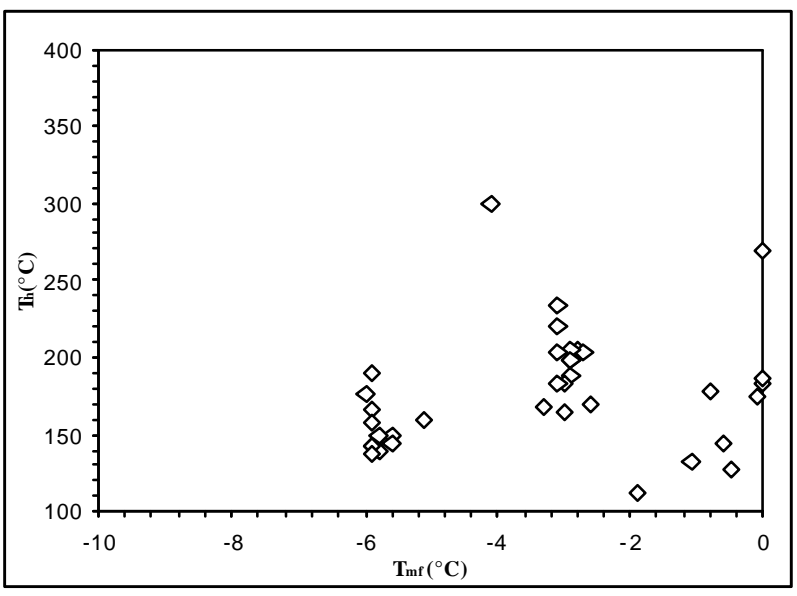

Fig. 6.7 Microthermomtric results of

fluid inclusions in the Lidu eclogite

\subsection{Fluid inclusions in the Raobazhai eclogite}

In Raobazhai, fluid inclusions mainly occur in the garnet porphyroblasts. Pyroxene is mostly devoid of fluid inclusions, or contains only fluid inclusion relics, whose contents have been consumed by reactions with the host mineral. In the newly-formed plagioclase, only a few carbonic inclusions occur. Based on their textural criteria and chemical compositions, four types of fluid inclusions were distinguished in the large garnet grains (Fig. 6.8):

(1) High-salinity aqueous inclusions with or without $\mathrm{N}_{2}$ are found in the core of garnet crystals: These inclusions occur as isolated or as groups (Fig. 6.8, photo a). Most contain halite(s) as a daughter phase. Their morphologies indicate late modification, probably during retrogression. Some of the fluid inclusions have variable amounts of $\mathrm{N}_{2} \pm \mathrm{CO}_{2}$. During cooling, the $\mathrm{H}_{2} \mathrm{O}$ phase of these inclusions was frozen at temperatures around $-60^{\circ} \mathrm{C}$. At about $-85{ }^{\circ} \mathrm{C}$, sometimes very small solids, probably $\mathrm{CO}_{2}$ and clathrate, could be observed around the gas species phase. At temperatures of about $-160{ }^{\circ} \mathrm{C}$ and below, a bubble appears in the non-aqueous part of the inclusion. During subsequent warming, the bubble homogenizes to liquid at temperatures of -148 to $-157{ }^{\circ} \mathrm{C}$ (Fig. 6.9a). These homogenization temperatures indicate that $\mathrm{N}_{2}$ is the major component of the gas phase (Van den Kerkhof, 1988). The detection of melting is mostly inaccurate. The eutectic melting of -42 to $-37{ }^{\circ} \mathrm{C}$, and final ice melting temperatures of -15 to $-24{ }^{\circ} \mathrm{C}$, indicate a $\mathrm{NaCl}$-dominated solution, but minor $\mathrm{Ca}^{2+}$ is possibly present (Fig. 6.9b). Melting of $\mathrm{N}_{2}$-clathrate was observed between -11 to $-13{ }^{\circ} \mathrm{C}$. Additionally, rare clathrate melting temperatures between 10 and $14{ }^{\circ} \mathrm{C}$ confirm the presence of minor $\mathrm{CO}_{2}$. The halite melting temperatures are between 144 and $332{ }^{\circ} \mathrm{C}$. 


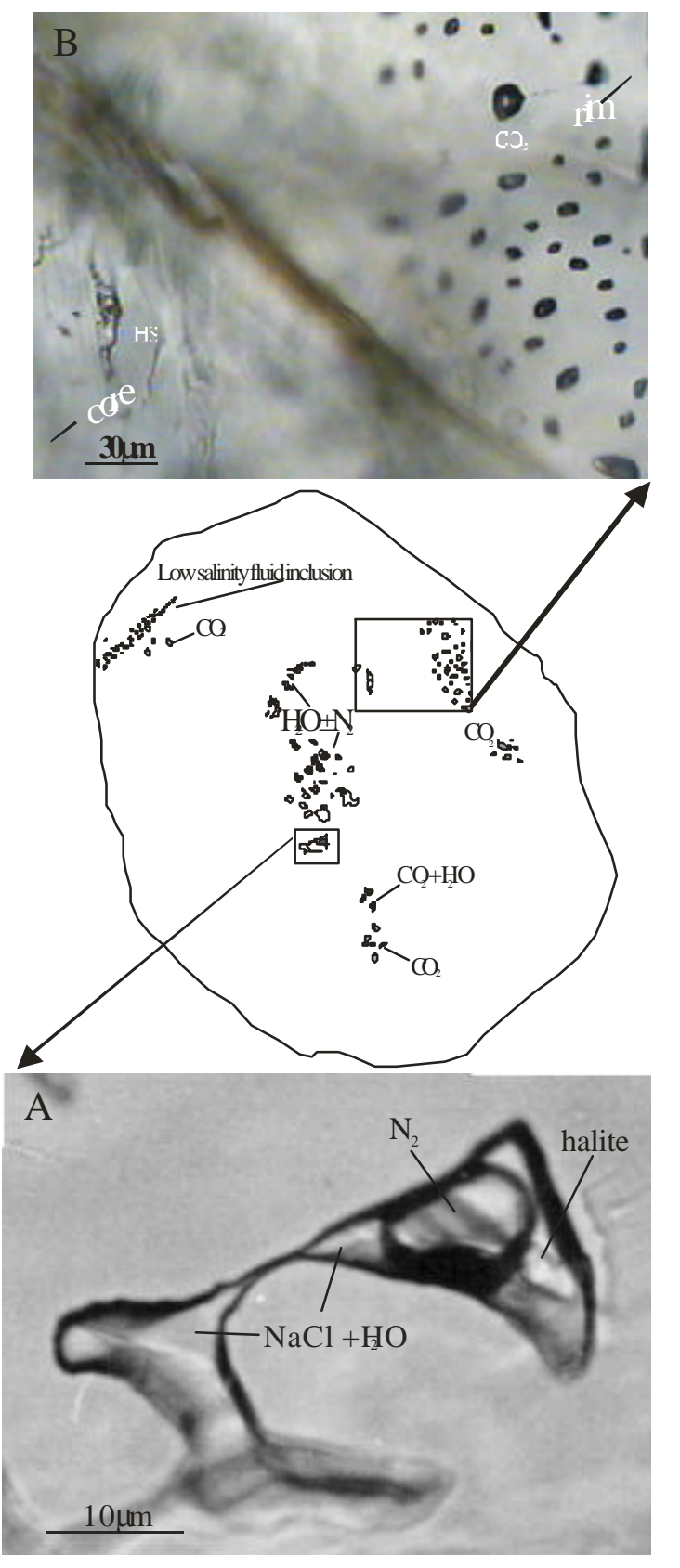

Fig. 6.8. Textural realtions between different types of fluid inclusions in garnet from Raobazhai. The figure combines textural relations from different grains in polished sections. HS, high salinity aqueous inclusions.

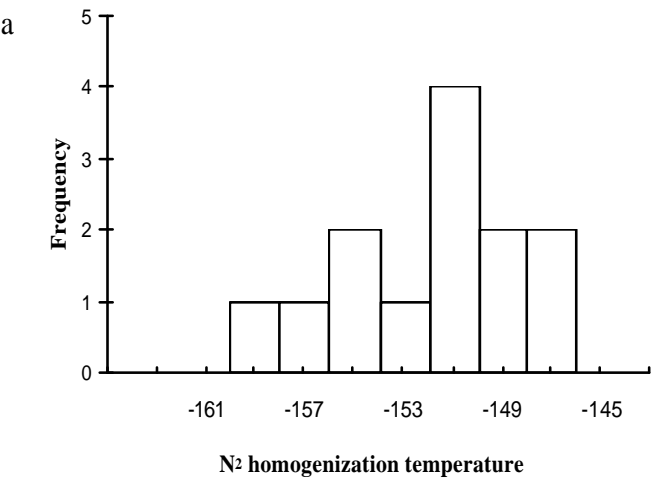

b
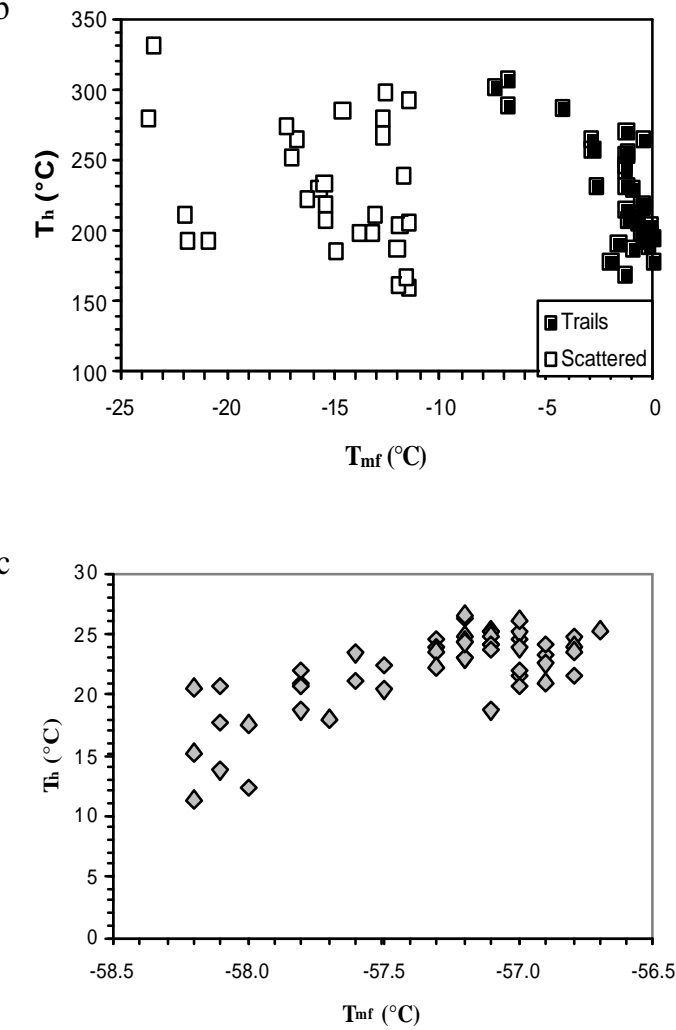

Fig. 6.9. (a) $\mathrm{N}_{2}$ homogenization temperature histogram for $\mathrm{N}_{2}$ bearing fluid inclusions. (b) Microthermometeric results of aqueous inclusions in garnet. (c) Microthermometeric results of carbonic inclusions in garnet.

(2) The majority of fluid inclusions are represented by carbonic inclusions in garnet. They were found predominantly along the rims of large garnet grains, indicating that they were trapped during the late growth stage of the garnet (Fig. 6.8, photo b). These carbonic inclusions occur as planar clusters, but they do not occur in healed fractures. Most of the 
inclusions contain small solids, indicating possible reactions between the host garnet and the inclusion fluids. They display final $\mathrm{CO}_{2}$ melting temperatures between -56.6 and $-58.2{ }^{\circ} \mathrm{C}$ indicative of almost pure $\mathrm{CO}_{2}$ and homogenization temperatures to liquid between 11 and $27^{\circ} \mathrm{C}$ (Fig. 6.9c).

(3) Two-phase late secondary fluid inclusions (fill degree of 80-95 vol\%) occur in healed fractures and show round morphologies. Microthermometric results show that they have final ice melting temperatures between -7 and $0{ }^{\circ} \mathrm{C}$ corresponding to low salinities, and homogenization temperatures of 163 to $332{ }^{\circ} \mathrm{C}$ (Fig. 6.9b).

(4) $\mathrm{H}_{2} \mathrm{O}-\mathrm{CO}_{2}$ inclusions were rarely found to coexist with high-salinity inclusions in the core of large garnet. These inclusions have fill degrees that considerably vary from 20 to $80 \mathrm{vol} \%$, implying imperfect local mixing of the two fluids. The $\mathrm{CO}_{2}$-phase of these inclusions shows melting temperatures from -57.5 to $-56.8{ }^{\circ} \mathrm{C}$, indicating the presence of almost pure $\mathrm{CO}_{2}$. Their homogenization temperatures to liquid are between 21 and $25^{\circ} \mathrm{C}$.

Isochores were calculated for both the aqueous and carbonic inclusions in garnet using the empirical equation for $\mathrm{H}_{2} \mathrm{O}-\mathrm{NaCl}$ and $\mathrm{CO}_{2}$ of Brown \& Lamb (1989), for temperatures in excess of $700{ }^{\circ} \mathrm{C}$ and pressures in excess of $3 \mathrm{kbar}$. The isochores for the high-salinity inclusions $\left( \pm \mathrm{N}_{2}\right)$ fall into the range of $10-12 \mathrm{kbar}$ at $750{ }^{\circ} \mathrm{C}$; isochores for pure carbonic inclusions indicate $3 \mathrm{kbar}$ at $800{ }^{\circ} \mathrm{C}$, whereas isochores for the low-salinity inclusions indicate $45 \mathrm{kbar}$ at $600{ }^{\circ} \mathrm{C}$. It should be noted that the isochores for all inclusion fluids are not conformable to peak or retrograde metamorphic pressures, indicating that most fluid inclusions were partially modified during uplift of the rock. However, due to limited fluid mobility, the compositions of the fluid in the inclusions are likely to represent the primary composition of the fluids trapped at different metamorphic conditions, which will be discussed below in more detail.

\subsection{Fluid inclusions in granulite from Yanzihe}

Fluid inclusions are moderately abundant in garnet, quartz blebs in garnet, and highly abundant in matrix quartz in granulite from Yanzihe. Three generations of fluid inclusions were distinguished in the granulite based on textural criteria:

Generation 1: $\mathrm{H}_{2} \mathrm{O}-\mathrm{CO}_{2}$ and carbonic inclusions in quartz blebs in garnet occur isolated or scattered in groups and clusters, and have rounded or negative crystal shapes. They are interpreted as formed early (primary). In most groups or clusters, $\mathrm{H}_{2} \mathrm{O}-\mathrm{CO}_{2}$ and carbonic inclusions occur together, without evidence of age difference. This suggests simultaneous 
trapping of the two fluids, most probably during primary growth of the host quartz blebs. Most of the carbonic inclusions are monophase inclusions at room temperature; only few inclusions with a vapor bubble have been observed. According to Roedder (1984), apparently monophase $\mathrm{CO}_{2}$-dominated inclusions may contain up to $10 \% \mathrm{H}_{2} \mathrm{O}$, which coats the walls of the inclusions as a thin film. However, clathrate melting was not observed in these inclusions. The $\mathrm{H}_{2} \mathrm{O}-\mathrm{CO}_{2}$ inclusions are usually 2-phase, liquid $\mathrm{H}_{2} \mathrm{O}$ and liquid $\mathrm{CO}_{2}$, at room temperature. These $\mathrm{H}_{2} \mathrm{O}-\mathrm{CO}_{2}$ inclusions have fill degrees of $\mathrm{H}_{2} \mathrm{O}$ ranging from 10 to $80 \%$ in volume.

Generation 2: $\mathrm{H}_{2} \mathrm{O}-\mathrm{CO}_{2}$ and carbonic inclusions (no visible water) were observed in garnet and in matrix quartz. They are isolated or randomly distributed inclusions and assumed primary. Like the fluid inclusions in quartz blebs, they are mostly monophase liquid- $\mathrm{CO}_{2}$ or two-phase $\mathrm{H}_{2} \mathrm{O}+\mathrm{CO}_{2}$ inclusions, however, $\mathrm{H}_{2} \mathrm{O}$ occurs less than $10 \%$ in volume in the 2phase inclusions. The morphologies are generally irregular because most of them have been strongly modified (Fig. 6.10A). Most of the carbonic inclusions contain fine-grained solids in addition to the fluid, indicating reactions between garnet and the inclusion fluids. The close textural relationship between $\mathrm{H}_{2} \mathrm{O}-\mathrm{CO}_{2}$ inclusions and carbonic inclusions and their coexistence in garnet and in matrix quartz suggest that the fluid inclusions may have been trapped simultaneously during the growth of garnet and matrix quartz.

Generation 3: Secondary $\mathrm{H}_{2} \mathrm{O}-\mathrm{CO}_{2}$ and carbonic inclusions in matrix quartz. These fluid inclusions are bound to healed microfractures, which normally cross-cut quartz grain boundaries (Fig. 6.10B). They have roundish or negative crystal morphologies. The $\mathrm{H}_{2} \mathrm{O}-\mathrm{CO}_{2}$ inclusions have fill degrees of water ranging from 10 to $90 \%$ in volume. Textures suggest that the two fluids were trapped at the same time.
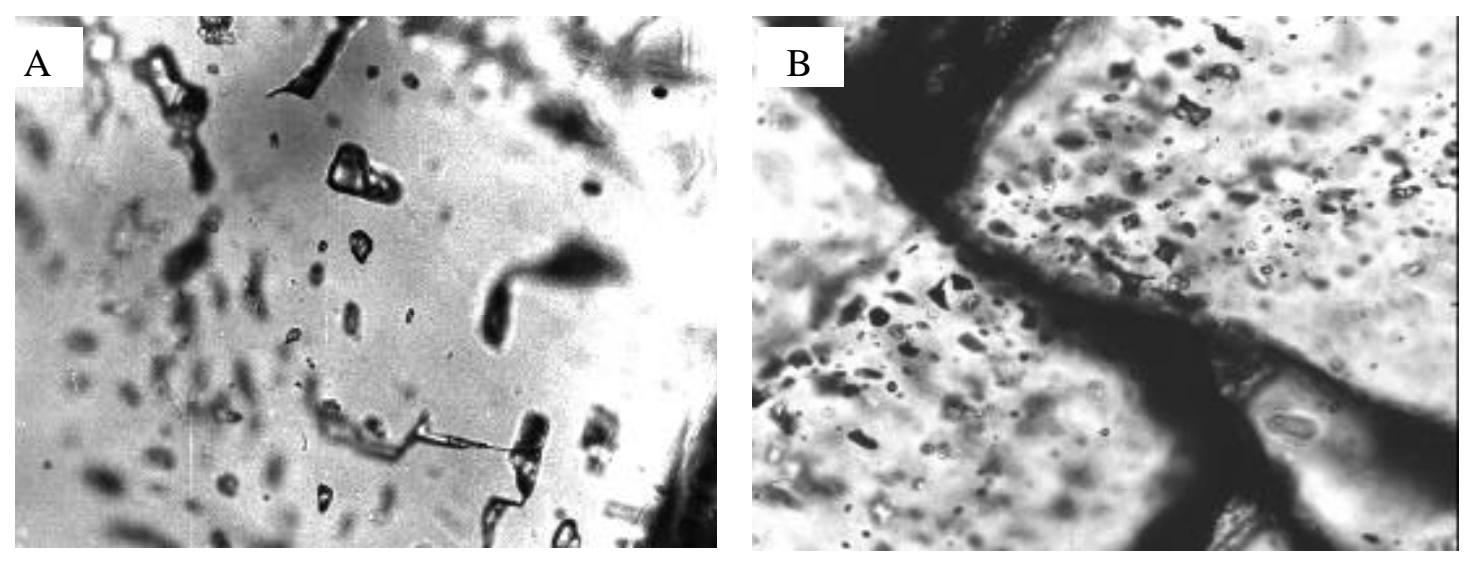

Fig. 6.10. Photomicrographs of fluid inclusions in the granulite from Yanzihe. (A) Carbonic inclusions in garnet, note the inclusions have been strongly modified; (B) Secondary carbonic inclusions in matrix quartz. 
Microthermometric results for the fluid inclusions in granulite are shown in Fig. 6.11. Most inclusions homogenize to the liquid phase; homogenization to the vapor was also rarely observed. The carbonic inclusions in quartz blebs in garnet show $\mathrm{CO}_{2}$ melting temperatures from -58 to $-59{ }^{\circ} \mathrm{C}$ and homogenization temperatures of $\mathrm{CO}_{2}$ (to liquid) between 11 and 16 ${ }^{\circ} \mathrm{C}$, whereas $\mathrm{H}_{2} \mathrm{O}-\mathrm{CO}_{2}$ inclusions have $\mathrm{CO}_{2}$ melting temperatures from -57.5 to $-58{ }^{\circ} \mathrm{C}$ and homogenization temperatures from 23 to $24{ }^{\circ} \mathrm{C}$. Different melting and homogenization temperatures between the 2 types of fluid inclusions may be due to the forming of clathrate in the $\mathrm{H}_{2} \mathrm{O}-\mathrm{CO}_{2}$ inclusions. Carbonic fluid inclusions in garnet display melting temperatures of 58.5 to $-59.5{ }^{\circ} \mathrm{C}$ and homogenization temperatures of -17 to $20{ }^{\circ} \mathrm{C}$. Primary inclusions in matrix quartz show $\mathrm{CO}_{2}$ melting temperatures between -58 and $-59{ }^{\circ} \mathrm{C}$ and homogenization temperatures between 6 and $20{ }^{\circ} \mathrm{C}$. Secondary inclusions in matrix quartz have $\mathrm{CO}_{2}$ melting temperatures of -57 to $-58{ }^{\circ} \mathrm{C}$ and $\mathrm{CO}_{2}$ homogenization temperatures of 17 to $27{ }^{\circ} \mathrm{C}$. Some secondary $\mathrm{H}_{2} \mathrm{O}-\mathrm{CO}_{2}$ inclusions in matrix quartz display ice melting temperatures around $0{ }^{\circ} \mathrm{C}$, indicating a pure-water system besides the $\mathrm{CO}_{2}$-rich phase. The melting temperatures of all fluid inclusions are indicative of the presence of minor $\mathrm{N}_{2}$ and/or $\mathrm{CH}_{4}$ addition to $\mathrm{CO}_{2}$. However, it is evident that the fluid inclusions contain more $\mathrm{N}_{2}$ and/or $\mathrm{CH}_{4}$ compared to the secondary fluid inclusions.

Unlike isochores for inclusions in eclogite, isochores for $\mathrm{CO}_{2}-\mathrm{H}_{2} \mathrm{O}$ inclusions in garnet and matrix quartz are conformable to peak-metamorphic conditions, whereas isochores for $\mathrm{CO}_{2}$ inclusions in garnet and matrix quartz falls $7 \mathrm{~kb}$ short of the estimated peak metamorphic conditions. As mentioned previously, however, these two types of inclusions were trapped simultaneously without any relative age difference. This disagreement may suggest that some of the volatile components are selectively consumed by reactions between the fluid in inclusions and garnet. The presence of solid phases in the carbonic inclusions in garnet provides support to this suggestion. The texturally earliest inclusions are $\mathrm{CO}_{2}$ and $\mathrm{H}_{2} \mathrm{O}+\mathrm{CO}_{2}$ inclusions in quartz blebs in garnet, which are assumed to be trapped during prograde metamorphism. Their highest-density isochore correlates to $6 \mathrm{kbar}$ at $600{ }^{\circ} \mathrm{C}$. 


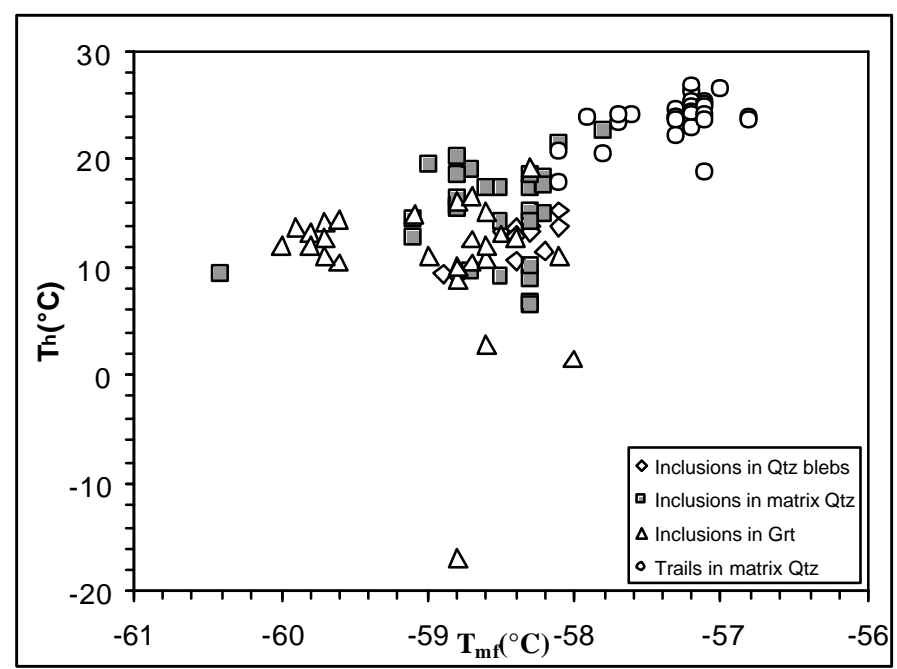

Fig.6.11. Microthermomtric results for carbonic inclusions in the Yanzihe granulite. The low melting temperatures are the indicative of the presence of additional $\mathrm{N}_{2}$ and/or $\mathrm{CH}_{4}$.

Fluid inclusions studies show that the fluids in the granulite from Yanzihe are dominated by $\mathrm{CO}_{2}$ with minor $\mathrm{N}_{2}$ and/or $\mathrm{CH}_{4}$. The fluids evolved from relatively water-rich during prograde metamorphism towards relatively $\mathrm{CO}_{2}$-rich solutions during peak metamorphism. During the retrograd metamorphism, the fluids became again water-rich but with less $\mathrm{N}_{2}$ and/or $\mathrm{CH}_{4}$ compared to the prograde- and peak-metamorphism. 
Chapter 7. OXYGEN AND HYDROGEN ISOTOPE

CHARACTERISTICS OF THE METAMORPHIC ROCKS IN

THE DABIE SHAN AREA

\subsection{Oxygen isotope compositions}

Oxygen isotope compositions were determined with UV laser-probe by in situ measurements on minerals (Fiebig et al., 1999). Oxygen isotopic mineral data from individual localities are listed in Table 7.1 and shown in Fig. 7.1.

Table 7.1. Oxygen isotope compositions of minerals from Dabie Shan

\begin{tabular}{|c|c|c|c|c|c|c|c|c|c|c|c|c|}
\hline Locality & Sample & $\begin{array}{l}\delta^{18} \mathrm{O} \\
\mathrm{Qtz}^{\mathrm{a}}\end{array}$ & $\begin{array}{l}\delta^{18} \mathrm{O} \\
\mathrm{Grt}\end{array}$ & $\begin{array}{l}\delta^{18} \mathrm{O} \\
\mathrm{Cpx}\end{array}$ & $\begin{array}{l}\delta^{18} \mathrm{O} \\
\text { Opx }\end{array}$ & $\begin{array}{l}\delta^{18} \mathrm{O} \\
\mathrm{Ky}\end{array}$ & $\begin{array}{l}\delta^{18} \mathrm{O} \\
\mathrm{Phn}\end{array}$ & $\begin{array}{l}\delta^{18} \mathrm{O} \\
\text { Sym }\end{array}$ & $\begin{array}{l}\delta^{18} \mathrm{O} \\
\mathrm{Pl}\end{array}$ & $\begin{array}{l}\delta^{18} \mathrm{O} \\
\mathrm{Am}\end{array}$ & $\begin{array}{l}\delta^{18} \mathrm{O} \\
\mathrm{Ol}\end{array}$ & $\begin{array}{l}\delta^{8} \mathrm{O} \\
\mathrm{WR}^{\mathrm{b}}\end{array}$ \\
\hline \multicolumn{13}{|c|}{ SDT } \\
\hline \multirow[t]{12}{*}{ Bixiling } & Retro- & $\begin{array}{l}2.2 \\
1.7\end{array}$ & $\begin{array}{l}-1.2 \\
-1.5\end{array}$ & $\begin{array}{l}-0.6^{\mathrm{d}} \\
-0.8^{\mathrm{d}}\end{array}$ & & & $\begin{array}{l}-1.2 \\
-1.4\end{array}$ & $\begin{array}{l}0.0 \\
-0.1\end{array}$ & 0.4 & & & -0.5 \\
\hline & $\begin{array}{l}\text { graded } \\
\text { eclogite }\end{array}$ & 0.8 & -1.8 & & & & & & & & & \\
\hline & (DB02) & $\begin{array}{l}0.9 \\
0.9\end{array}$ & $\begin{array}{l}-1.9 \\
-1.6\end{array}$ & & & & & & & & & \\
\hline & Fresh & $4.5^{\mathrm{d}}$ & 3.3 & 3.6 & & & & & & & & 3.7 \\
\hline & eclogite & & 3.8 & 3.9 & & & & & & & & \\
\hline & (DB05) & & 3.4 & 3.9 & & & & & & & & \\
\hline & & & 3.5 & $\begin{array}{l}3.0 \\
3.9\end{array}$ & & & & & & & & \\
\hline & Ky-rich & 5.0 & 3.0 & 3.2 & & 4.0 & & & & & & 3.5 \\
\hline & $\begin{array}{l}\text { eclogite } \\
\text { (DB07) }\end{array}$ & 5.1 & $\begin{array}{l}3.3 \\
3.2\end{array}$ & 3.4 & & 4.1 & & & & & & \\
\hline & Gt-peri- & & 3.2 & 3.1 & 3.2 & & & & & & 2.8 & 3.4 \\
\hline & dotite & & 3.4 & 3.6 & 3.4 & & & & & & 2.6 & \\
\hline & (DB10) & & 3.6 & 3.5 & 3.2 & & & & & & 2.9 & \\
\hline \multirow{3}{*}{ Shima } & Fresh & & 6.6 & 6.8 & & & & & & & & 6.6 \\
\hline & Eclooite & & 6.4 & 6.7 & & & & & & & & \\
\hline & (DB63) & & 6.4 & 6.6 & & & & & & & & \\
\hline \multirow[t]{5}{*}{ Shuanghe } & Jadeite & 9.7 & 7.8 & 8.4 & & & & 8.5 & & & & 8.8 \\
\hline & quartzite & 9.4 & 7.2 & 8.4 & & & & 8.9 & & & & \\
\hline & & 9.5 & 7.5 & 8.5 & & & & & & & & \\
\hline & & 9.5 & & $\begin{array}{l}8.2 \\
8.3\end{array}$ & & & & & & & & \\
\hline & & & & $\begin{array}{l}7.9 \\
7.8\end{array}$ & & & & & & & & \\
\hline \multirow[t]{3}{*}{ Lidu } & “cold" & -1.0 & -4.6 to & $-2.4^{\mathrm{d}}$ & & -2.3 & -3.1 & -1.7 & & & & -2.8 \\
\hline & eclogite & -0.7 & -3.3 & & & & -3.6 & & & & & \\
\hline & & $\begin{array}{l}-0.7 \\
-0.9\end{array}$ & $\begin{array}{l}(78 \\
\text { spots) }\end{array}$ & & & & & & & & & \\
\hline \multicolumn{13}{|c|}{ NDC } \\
\hline & Eclogite & & +6.4 & 6.5 & & & & 6.0 & $5.7^{\mathrm{d}}$ & $6.0^{\mathrm{d}}$ & & 6.7 \\
\hline Raobazhai & $(\mathrm{R}-14)^{\mathrm{c}}$ & & $\begin{array}{l}\text { to } \\
+6.7\end{array}$ & 6.5 & & & & & & 6.1 & & \\
\hline & & & $(14$ & & & & & & & & & \\
\hline \multirow{7}{*}{ Yanzihe } & & & spots) & & & & & & & & & \\
\hline & Granulite & 11.2 & +6.8 & & 7.5 & & & & & $7.4^{\mathrm{e}}$ & & 9.9 \\
\hline & $(\mathrm{Y}-1)^{\mathrm{c}}$ & 11.1 & to & & 7.8 & & & & & 7.6 & & \\
\hline & & 11.0 & +9.3 & & 7.4 & & & & & & & \\
\hline & & 10.8 & (31 & & & & & & & & & \\
\hline & & 11.2 & & & & & & & & & & \\
\hline & & 11.3 & & & & & & & & & & \\
\hline
\end{tabular}


${ }^{a}$ Abbreviations are after Kretz, 1983, except $P h n$ phengite, Sym symplectite, $P$ l plagioclase, $W R$ whole-rock

${ }^{\mathrm{b}}$ Whole-rock $\delta^{18} \mathrm{O}$ values are estimated from major components

${ }^{c}$ Oxygen isotope mappings have been completed for large garnets from Lidu, Raobazhai and Yanzihe; in this table only a range of $\delta^{18} \mathrm{O}$ values of garnets has been presented; for details see Figs. 8.4, 8.5 and 8.6 respectively

d Omphacites in DB02 contain various amounts of symplectite (intergrowths of albite, amphibole and/or Capyroxene); quartz in DB05 is a mixture of quartz and garnet; Oxygen isotope data for Cpx, Pl and Am from Lidu and Raobazhai represent mixtures of different proportions of these minerals

${ }^{\mathrm{e}} \mathrm{A}$ mixture of Clrich and Cl-free amphiboles

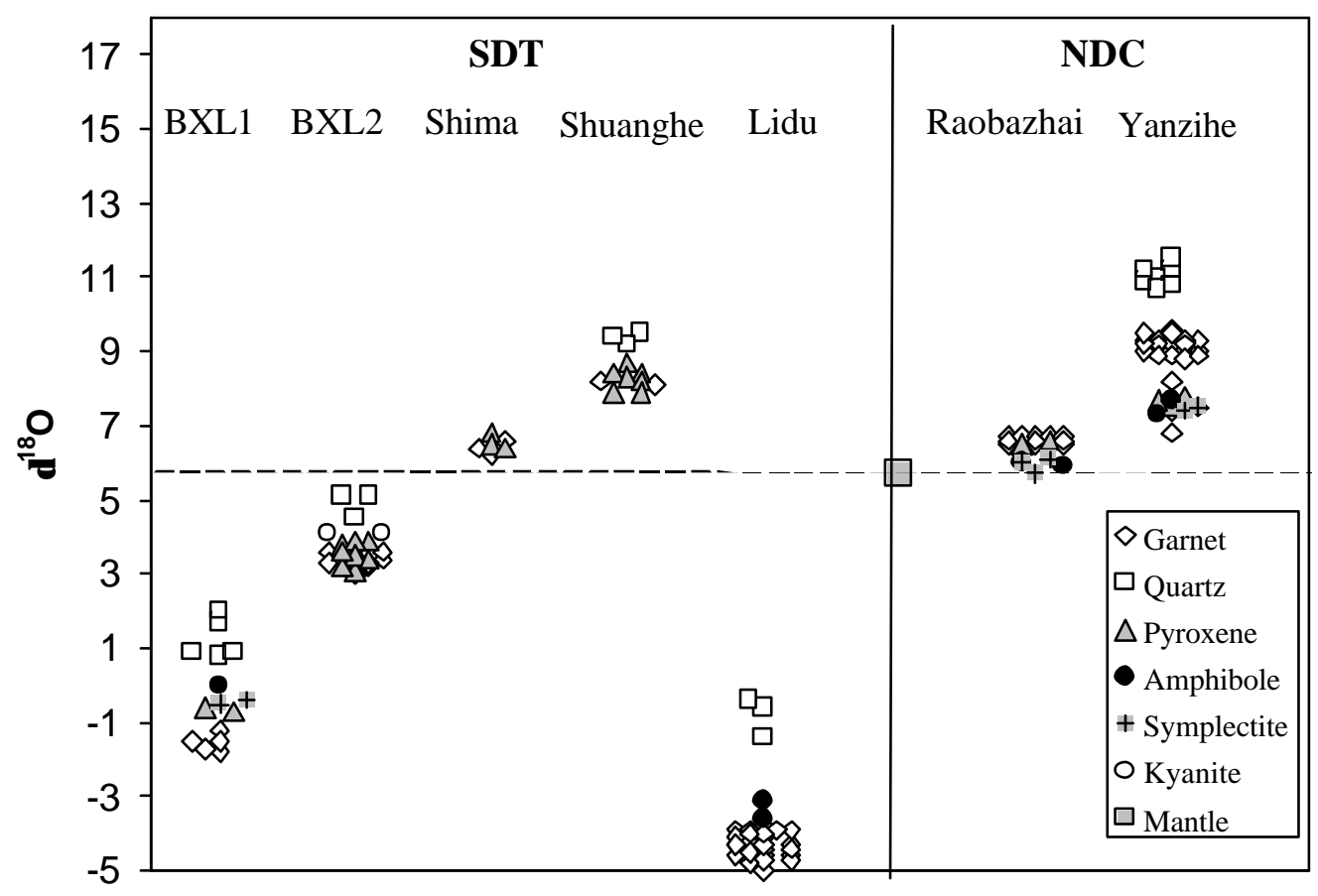

Fig. 7.1 $\delta^{18} \mathrm{O}_{\text {VSMOW }}$ values of coexisting minerals from the investigated localities. BXL1 retrograded eclogite from Bixiling; BXL2 “fresh” eclogites from Bixiling

\subsubsection{Oxygen isotope data from Bixiling}

Metamorphic rocks have generally oxygen isotope values that are commonly similar to their igneous and sedimentary protoliths ranging from +6 to $+18 \%$ (Hoefs 1997). The oxgen isotopic values of the rocks from Bixiling are significantly lower than the compositions anticipated for the presumed pristine igneous protolith of these rocks, indicating water-rock interaction prior to subduction. This is in agreement with the findings of other workers (e.g. Yui et al. 1995, 1997; Baker et al. 1997; Rumble and Yui 1998; Zheng et al. 1998, 1999). 
The three principal rock types in Bixiling (>95 vol\% of the rock body), including "fresh" eclogite, kyanite-rich eclogite and garnet-peridotite, have whole-rock oxygen isotope values around $3.5 \%$, whereas the retrograded eclogite has a $\delta^{18} \mathrm{O}$ value of $-0.5 \%$. Oxygen isotope variations in the minerals from the fresh eclogites and the ultramafic rock are small and indicate high equilibrium temperatures (Fig. 7.2). As shown in Table 7.1, garnets and clinopyroxenes from the "fresh" eclogite, the kyanite-rich eclogite and the garnet peridotite have more or less the same values ranging from 3.0 to $3.9 \%$. The whole-rock $\delta^{18} \mathrm{O}$ values of "fresh" eclogite, kyanite-rich eclogite and garnet peridotite were estimated to be of $3.7 \%$, $3.5 \%$, and $3.4 \%$, respectively, based on mineral $\delta^{18} \mathrm{O}$ values and modal abundance. In contrast, the minerals in retrograded eclogite have $\delta^{18} \mathrm{O}$ values of -1.8 to $-1.2 \%$ for garnet and of -1.1 to $-0.6 \%$ for omphacite. The whole-rock $\delta^{18} \mathrm{O}$ values of retrograded eclogite was estimated to be $-0.5 \%$ o, which is about 4 per mil lower than those of the former three principal rock types. Such an oxygen isotope compositional difference probably indicates a retrograde fluid/rock interaction.
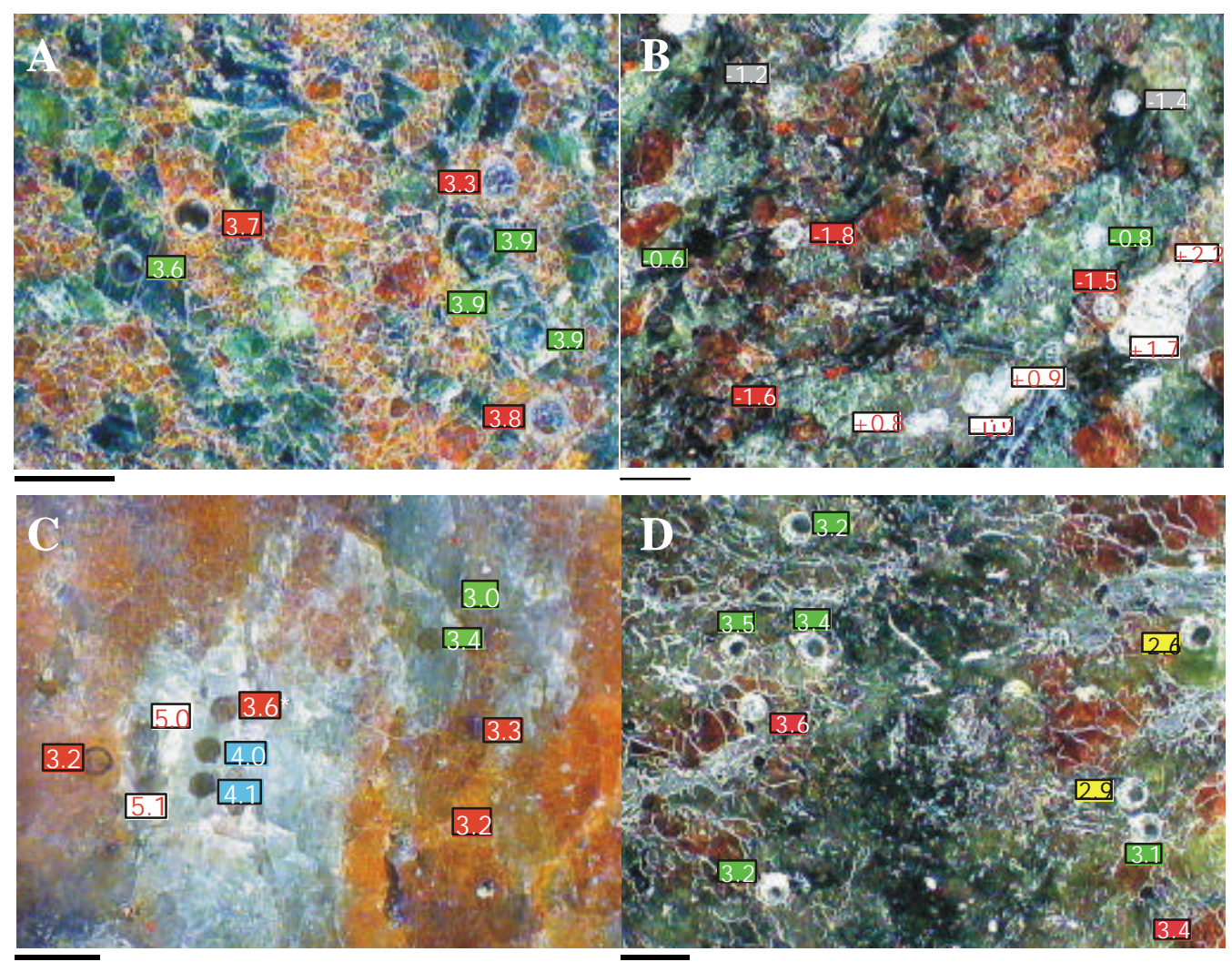

5.1 quark 3.7 gamet 3.9 pyroxene 4.0 , kyanite 2.9 olivine $\quad[1.1$ phengite

Fig. 7.2 Photomicrographs of the oxygen isotope laser-probe measurements on minerals in rocks from Bixiling. (A) "fresh" eclogite, DB05; (B) retrograded eclogite, DB02; (C) kyanite-rich eclogite; (D) garnet-peridotite. Not all measured points are presented in this figure. Scale bar $=1 \mathrm{~mm}$. 
The $\delta^{18} \mathrm{O}$ values of all phases in the investigated samples from Bixiling are homogeneous in hand specimens and are nearly constant within the whole body except for the margin, in which the retrograded eclogite was collected. The sequence of ${ }^{18} \mathrm{O}$ enrichment in the minerals from all the samples is concordant with equilibrium fractionations (Zheng et al. 1993a, 1993b). The identical oxygen isotope compositions among the "fresh" eclogite, kyanite-rich eclogite and garnet peridotite suggests that water-rock interaction before subduction was nearly homogeneous on a scale of almost 1000 meters regardless of bulk composition. The $\delta^{18} \mathrm{O}$ values of the retrograded eclogite being about 4 per mil lower than those of the fresh eclogites and coexisting ultramafic rock, but are similar to the oxygen isotope compositions of the surrounding gneiss, which has a $\delta^{18} \mathrm{O}$ value of $\sim 0.4 \%$ (Zheng et al. 1999). From a summary of the oxygen isotope data for the eclogites and their country rocks in the Dabie-Sulu area published so far, we can deduce a close relationship in $\delta^{18} \mathrm{O}$ values between eclogites and their country rocks (e.g. Baker et al. 1997; Rumble and Yui 1998; Zheng et al. 1998). Thus it is possible that the retrograded eclogite and surrounding gneiss in Bixiling has been subjected to a similar fluid/rock interaction history during retrograde metamorphism.

\subsubsection{Oxygen isotopic compositions of the Shima eclogite}

The $\delta^{18} \mathrm{O}$ values of minerals in the eclogite from Shima fall within a narrow range from +6.4 to $6.6 \%$ or garnet and from +6.4 to $6.8 \%$ for omphacite (Table 7.1). Because omphacite and garnet are dominant constituents of the eclogite, the whole-rock $\delta^{18} \mathrm{O}$ value of the Shima eclogite are calculated to be about $6.6 \%$ based on mineral isotopic compositions.

The $\delta^{18} \mathrm{O}$ values are slightly higher than that of the mantle and consist with the low end of normal metamorphic rocks (Hoefs, 1997). This implies either that its protolith has not been affected by the meteoric water alteration prior to subduction, i.e. the $\delta^{18} \mathrm{O}$ value of $6.6 \%$ o represents the oxygen isotope compositions of a basaltic protoliths, or alternatively that the protolith had primarily higher $\delta^{18} \mathrm{O}$ values which due to a meteoric water/rock interaction have been reduced to the $\delta$-values observed today. It has been shown that the eclogite (DB63) is characterized by high REE contents and a LREE-enriched pattern; this feature indicates either that the eclogite was metasomatized by a LREE-enriched fluid or melt before the UHP metamorphism (Cox et al., 1973) or that the protolith of the eclogite was derived from a metasomatized mantle. Zhang et al. (1998) measured lower $\delta^{18} \mathrm{O}$ values of 1.5 to $4.5 \%$ and suggested fluid/rock interactions before the Triassic UHP metamorphism for a mafic- 
ultramafic complex which is very close to our investigated eclogite. Thus, the explanation that the protolith of the Shima eclogite had primarily higher $\delta^{18} \mathrm{O}$ values and still have the relatively higher $\delta^{18} \mathrm{O}$ values after the meteoric water-rock interaction is more reasonable.

\subsubsection{Oxygen isotope measurements on the jadeite quartzite from Shuanghe}

At Shuanghe the $\delta^{18} \mathrm{O}$ values of minerals in the jadeite quartzite vary from +9.2 to $+9.7 \%$ o for quartz, from +7.6 to $8.5 \%$ o for jadeite and +7.3 to $+7.8 \%$ o for garnet, corresponding to whole- $\delta^{18} \mathrm{O}$ values of $+8.8 \%$ (Table 7.1). Five points on the same jadeite grain show $\delta^{18} \mathrm{O}$ values of 8.2 to $8.5 \%$, indicating homogeneous oxygen isotope compositions and a closed fluid system during jadeite growth (Fig. 7.3).

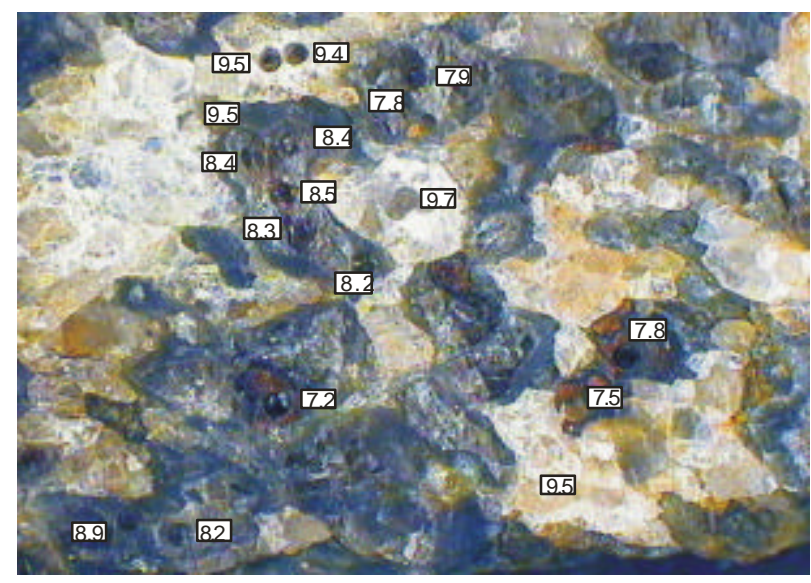

Fig. 7.3 Microphotograph from the jadeite quartzite in Shuanghe showing $\delta^{18} \mathrm{O}$ values (its protolith is assumed to be sedimentary).

The oxygen isotopic compositions of various metamorphic rocks from Shuanghe have been extensively studied (e.g. Zheng et al., 1998; Fu et al., 1999). These studies have shown a large variation in $\delta^{18} \mathrm{O}$ values of minerals from -2.6 to $7.0 \%$; ancient meteoric water is assumed to have exchanged oxygen isotopes with the eclogite precursors in the continental crust prior to the Triassic UHP metamorphism (Zheng et al., 1998). On the other hand, the jadeite quartzite in Shuanghe is a metasedimentary rock (see above, and Liou et al. 1997), thus its protolith would probably have primarily higher $\delta^{18} \mathrm{O}$ values than $10 \%$ (e.g. Hoefs, 1997); therefore, a meteoric water-rock interaction prior to peak metamorphism are assumed for both eclogite and jadeite quartzite from Shuanghe.

\subsubsection{Oxygen isotope zoning of garnets in the Lidu eclogite}


Using the in situ method, we determined the $\delta^{18} \mathrm{O}$ values of three large garnets in eclogites from Lidu. In the present study, each garnet was examined petrographically, and extreme care was taken to avoid any mineral inclusions during laser heating.

All three garnets studied in Lidu are concentrically zoned in oxygen isotopes. They have an $\mathrm{O}^{18}$ depleted core and rim but an ${ }^{18} \mathrm{O}$ enriched central zone. One example is shown in Fig. 7.4. The garnet has $\delta^{18 \mathrm{O}}$ values which increase from ca. $-4.5 \%$ in the core to ca. $-3.9 \%$ o in the central zone and decrease to ca. $-4.4 \%$ in the rim. It is unlikely that the observed zoning may be produced by mineral inclusions in garnet because mineral inclusions have been carefully avoided during laser ablation, and the $\delta^{18} \mathrm{O}$ variations of the three garnets are reproducible and remarkably systematic (Fig. 7.4). The isotopic zoning therefore most likely reflects variations of O-isotope compositions during garnet-growth.

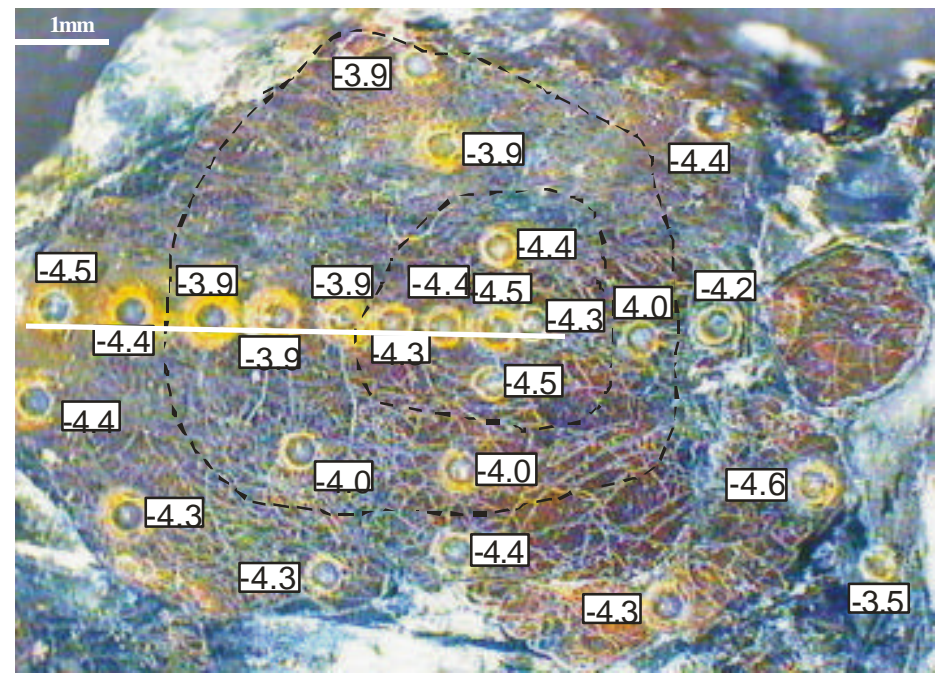

Fig. 7.4. Microphotograph from an eclogite of Lidu in the SDT showing low $\delta^{18} \mathrm{O}$ values in garnet (at the lower right side one phengite value). Numbers are $\delta^{18} \mathrm{O}$ values in per mil relative to SMOW. Dashed lines were drawn by hand and indicate differences in oxygen isotope compositions, reflecting changes in the evolution of fluids during garnet growth. The write line shows the position of laser-ICPMS analysis (see Fig. 5.12).

On the other hand, the $\delta^{18} \mathrm{O}$ values of other minerals in the eclogite vary from -0.6 to $-0.2 \%$ for quartz, from -3.1 to $-3.6 \%$ o for muscovite and from -3.5 to $-3.3 \%$ o for small garnet crystals in the matrix, and $-2.3 \%$ for kyanite, $-1.6 \%$ for plagioclase and $-1.7 \%$ for symplectite retrograded after omphacite. The calculated whole-rock $\delta^{18} \mathrm{O}$ value is $-2.8 \%$. Such low $\delta^{18} \mathrm{O}$ values can be explained only by isotope exchange with low ${ }^{18} \mathrm{O}$ meteoric fluids.

\subsubsection{Oxygen isotope compositions of the Raobazhai eclogite}

In order to explain the compositional zoning in both garnet and pyroxene from Raobazhai, one has to ask whether it was largely inherited from internal cation exchanges at 
various P-T conditions or, from the infiltration of fluids; in other words, whether the zoned garnet and pyroxene grew in a closed or an open system. One approach to resolve this problem is by oxygen isotope mapping of garnet.

$\delta^{18} \mathrm{O}$ values of 11 spots in a garnet porphyroblast (about $7 \mathrm{~mm}$ in size) and 10 spots in the surrounding matrix (small garnet, pyroxene, plagioclase, amphibole) from Raobazhai have been determined. Locations of analytical spots and $\delta^{18} \mathrm{O}$ values of garnet analyses relative $\mathrm{V}$ SMOW are shown in Fig. 7.5.

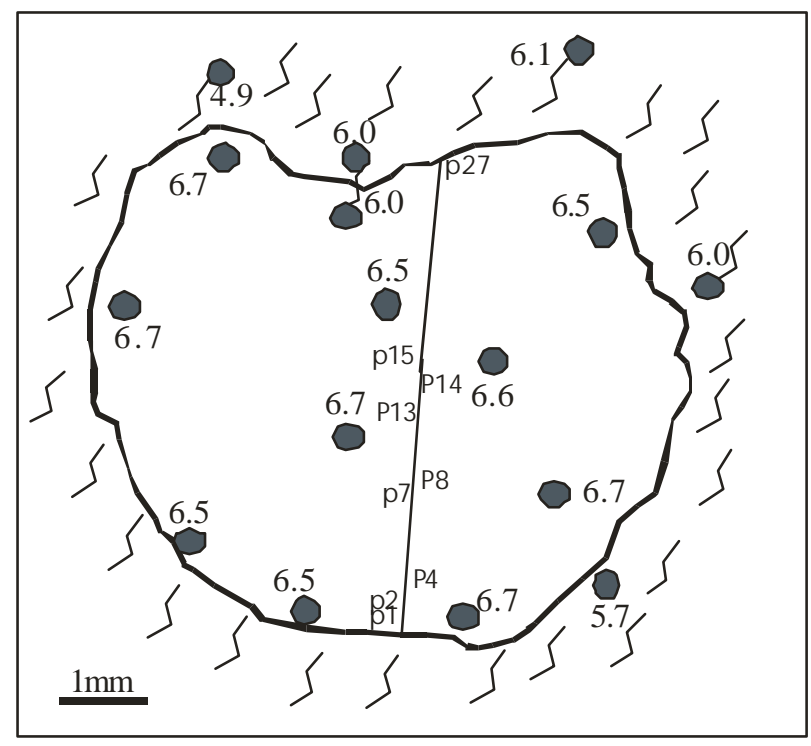

Fig. 7.5 Sketch of garnet showing $\delta^{18} \mathrm{O}$ values of analyzed spots. Matrix minerals are mainly plagioclase, clinopyroxene and amphibole. Sizes of oxygen isotope laser holes are about $300 \mathrm{~mm}$; not all analyzed spots of matrix are shown here. The line shows the location of a laser ICPMS profile, and numbers represent the analytical spots.

The garnet prophyroblast, except one analysis, is obviously homogeneous in oxygen isotopic composition, with an average $\delta^{18} \mathrm{O}$ value of $6.6 \pm 0.1 \%$. The one $\delta^{18} \mathrm{O}$ value of $6.0 \%$ o is from small veins of secondary amphibole close to the rim of the garnet. The garnet is almost inclusion free, and combined with the microprobe data after laser oxygen isotope measurements, indicates that no corrections for mineral inclusions are necessary. Small garnets (1-2 $\mathrm{mm}$ in size) are also unzoned with $\delta^{18} \mathrm{O}$ values of 6.4 to $6.6 \%$.

It is difficult to obtain $\delta^{18} \mathrm{O}$ values for pure pyroxene, plagioclase and amphibole because of their small crystal sizes. Pyroxene rims are usually replaced by symplectite consisting of clinopyroxene and plagioclase. Secondary amphibole only occurs as thin rims around garnet or pyroxene. Thus oxygen isotope data for pyroxene, plagioclase and amphibole represent a mixture of these minerals.

The nearly homogeneous oxygen isotopic composition of the garnet porphyroblast indicates closed system conditions during garnet growth. If any infiltrating fluids had been 
present during garnet growth, the garnets would become gradually zoned in ${ }^{18} \mathrm{O}$ from the rim towards the centre, because the isotopic front that is moving through the rock becomes less steep with increasing distance from the contact (Chamberlain \& Conrad, 1993). Therefore, no external fluids infiltrated the garnet pyroxenite during garnet growth.

The plagioclase (including minor amphibole and/or secondary pyroxene), amphibole (including minor secondary pyroxene and/or plagioclase) and symplectite have $\delta^{18} \mathrm{O}$ values of 4.8 to $5.7 \%$, 6.0 to $6.1 \%$, and $6.0 \%$, respectively (Table 7.1). According to published fractionation factors for these minerals (e.g., Zheng 1993a, 1993b) and theoretical models of diffusional reequilibration during cooling (e.g., Eiler et al., 1992), both plagioclase and amphibole should be richer in ${ }^{18} \mathrm{O}$ than garnet. However, relative to the garnet prophyroblast, which has $\delta^{18} \mathrm{O}$ values of about $6.6 \%$, the apparent fractionations between garnet and these retrograde minerals are -1.7 to $-0.3 \%$ (Table 7.1 ). These data thus indicate oxygen isotopic disequilibrium during retrograde metamorphism after the amphibolite stage. Oxygen isotopic compositions of the garnet prophyroblast and the compositional zoned pyroxene are nearly identical, indicating very high metamorphic temperatures or disequilibrium.

\subsubsection{Retrograde fluid/rock interaction indicators for the Yanzihe granulite}

The 31 analyses of garnets in the granulite from Yanzihe indicate that most garnets are homogeneous, with an average isotopic value of $9.1 \pm 0.2 \%$ o $(1 \sigma)$, except five analyses that have $\delta^{18} \mathrm{O}$ values from 6.8 to $8.8 \%$. The five analytical outliers are close to a micro vein of Cl-rich amphibole within the garnet.

As shown in Fig. 7.6A, a garnet porphyroblast (about $6 \mathrm{~mm}$ in diameter) has more or less homogeneous oxygen isotopic compositions of $9.1 \pm 0.2 \%$ in the upper right site, in which the garnet is vein-free. However, in the lower left site, close to secondary Clrich amphibole veins in the garnet, analytical spots show much lower $\delta^{18} \mathrm{O}$ values, ranging from 6.8 to $8.2 \%$, One analysis indicates that the amphibole vein has a $\delta^{18} \mathrm{O}$ value of $7.5 \%$ o. From microprobe and microscope data it can be concluded that these analytical spots with lighter oxygen isotopic compositions are definitely garnet rather than other minerals (Fig. 7.6b). On the other hand, as shown in section 5.2.6, REE laser-ICPMS analyses indicate a LREE enrichment for the lower $\delta^{18} \mathrm{O}$ spots (REE analytical positions are also shown in Fig. 7.6b). This relationship favors a retrograde fluid-rock interaction for the granulite from Yanzihe. Therefore, the patterns of oxygen isotope zoning in garnet from Yanzihe are quite different from those in garnet from Lidu, reflecting fluid-rock interactions during different metamorphic stages. 

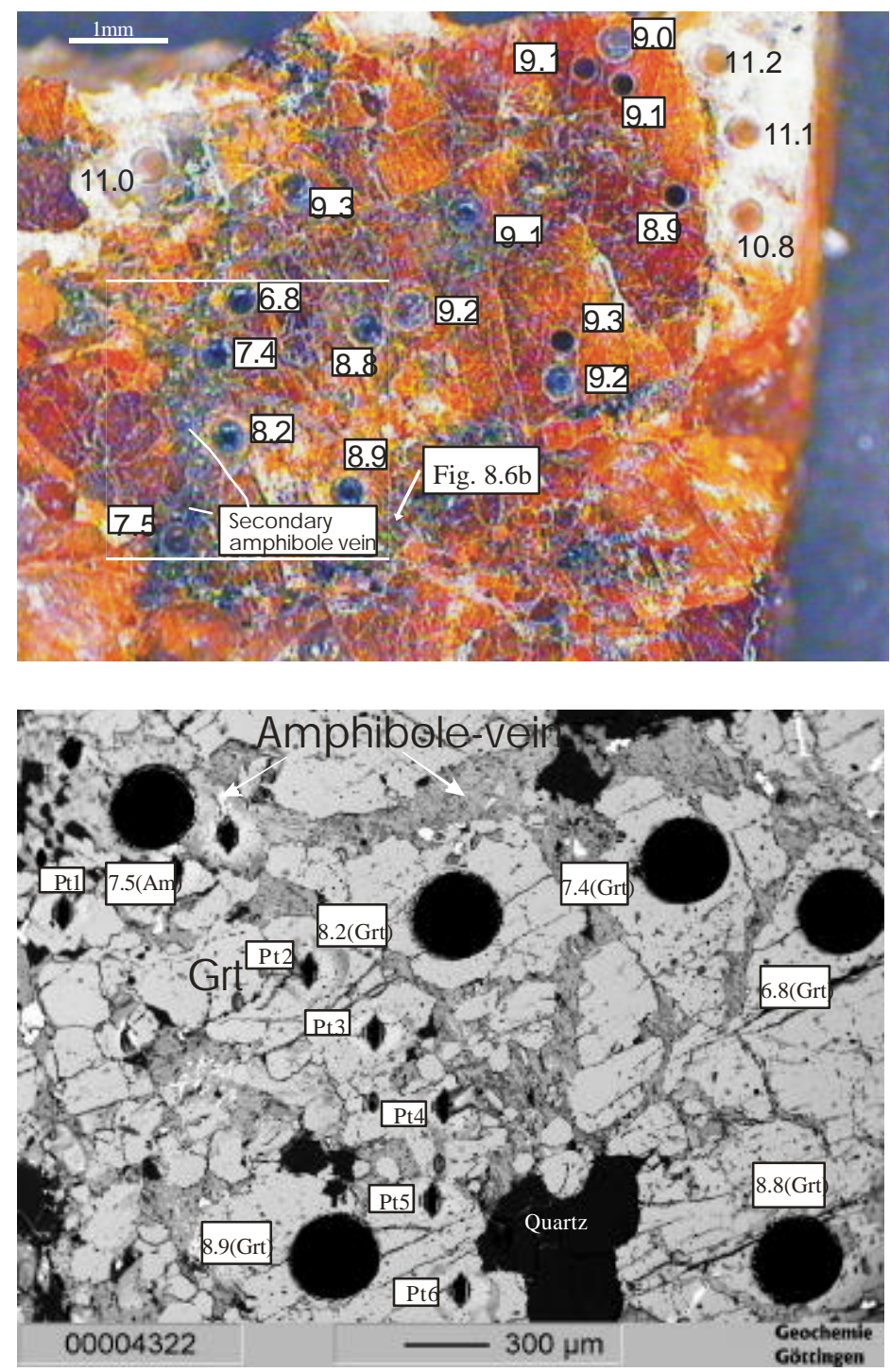

Fig. 7.6. (A) Microphotograph of a granulite from Yanzihe; a garnet in the granulite exhibits lower $\delta^{18} \mathrm{O}$ values along a secondary amphibole vein, indicating retrograde fluid-rock interaction; quartz-garnet pairs in the upper part indicate equilibrium temperatures of around $1000{ }^{\circ} \mathrm{C}$. (B) Photomicrograph of secondary Cl-rich amphibole veins in garnet shown in $\mathrm{A}$; the photo demonstrates that the analytical spots with lower $\delta^{18} \mathrm{O}$ values are definitely garnet rather than other minerals; Pt1, 2... represent the positions for REE laser-ICPMS analyses (see Fig. $5.14 b)$.

\subsection{Oxygen isotope thermometry}

Temperature estimates based on the isotopic fractionations between various phases are given in Table 7.2. Estimates are based on the theoretical calculations of Zheng (1993a, 1993b) and calibrations of Matthews (1994) except for the olivine-pyroxene pair which are based on the calibrations of Kyser et al. (1981). 
Table 7.2 Oxygen isotope temperature estimates. Abbreviations are after Kretz (1993), except Phn phengite. T1 temperature estimates based on Zheng (1993a, b) except the Ol-Cpx pair which is based on Kyser et al. (1981); T2 temperature estimates in terms of the calibrations of Mattews (1994).

\begin{tabular}{|c|c|c|c|c|c|c|}
\hline Locality & Sample & Mineral Pair & $\Delta^{18} \mathrm{O}$ & $\mathrm{T}_{1}\left({ }^{\circ} \mathrm{C}\right)$ & $\mathrm{T}_{2}\left({ }^{\circ} \mathrm{C}\right)$ & $\begin{array}{l}\text { Petrological } \\
\text { peak T } \\
\text { estimate }\end{array}$ \\
\hline \multirow{7}{*}{ Bixiling } & Retrograded & Qtz-Grt & $3.4-2.6$ & $700-840$ & $670-810$ & \multirow{3}{*}{$\begin{array}{l}\sim 1000{ }^{\circ} \mathrm{C} \\
\text { (based on the } \\
\text { omphacite } \\
\text { inclusions in } \\
\text { garnet) }\end{array}$} \\
\hline & \multirow[t]{2}{*}{ eclogite } & Qtz-Cpx & $2.8-2.5$ & $590-650$ & $470-515$ & \\
\hline & & Qtz-Phn & $2.3-2.0$ & $620-650$ & & \\
\hline & \multirow[t]{3}{*}{ "Fresh" eclogite } & Qtz-Grt & $2.0-1.8$ & $1010-1070$ & $960-1020$ & \multirow[t]{3}{*}{$\sim 1000^{\circ} \mathrm{C}$} \\
\hline & & Qtz-Cpx & $1.8-1.7$ & $840-870$ & $680-710$ & \\
\hline & & Qtz-Ky & 1.0 & 1070 & & \\
\hline & Grt-peridotite & Ol-Cpx & $1.0-0.3$ & $910-1090$ & & $\sim 1000{ }^{\circ} \mathrm{C}$ \\
\hline \multirow{2}{*}{ Shuanghe } & \multirow[t]{2}{*}{ Jadeite quatzite } & Qtz-Grt & $2.3-2.0$ & 920-1000 & $870-960$ & \multirow[t]{2}{*}{700 - 950} \\
\hline & & Qtz-Jd & $1.6-1.3$ & $770-890$ & $550-640$ & \\
\hline \multirow{3}{*}{ Lidu } & \multirow[t]{3}{*}{ Cold eclogite } & $\mathrm{Qtz}-\mathrm{Grt}$ & $3.7-3.4$ & $650-700$ & \multirow[t]{3}{*}{$630-670$} & \multirow[t]{3}{*}{$\sim 700$} \\
\hline & & $\mathrm{Qtz}-\mathrm{Phn}$ & $2.9-2.1$ & $500-670$ & & \\
\hline & & Qtz - Ky & 1.9 & 700 & & \\
\hline \multirow[t]{2}{*}{ Yanzihe } & \multirow[t]{2}{*}{ Granulite } & Qtz-Grt & $2.2-1.9$ & 940-1030 & \multirow[t]{2}{*}{ 900-990 } & \multirow[t]{2}{*}{$750-800$} \\
\hline & & Qtz-Opx & 3.5 & 550 & & \\
\hline
\end{tabular}

Isotope temperature estimates for the unaltered eclogites from Bixiling, the eclogite from Lidu and the jadeite quartzite from Shuanghe are in accordance with temperatures obtained from cation thermometers (see Chapter 8). Isotope temperatures for the retrograded eclogite from Bixiling are significantly lower than its peak metamorphic temperature, suggesting the effect of retrograde isotope exchange subsequent to the eclogite-facies metamorphism. Isotopic temperature estimates for eclogites from Shima and Raobazhai cannot be given because of the absence of suitable mineral pairs. 
On the other hand, oxygen isotope temperatures calculated from garnet and quartz in the granulite from Yanzihe give $900-1000{ }^{\circ} \mathrm{C}$, which are about $200{ }^{\circ} \mathrm{C}$ higher than those from the Grt-Opx thermometer of Lee and Ganguly (1988). However, Qtz-Opx pairs, give oxygen isotope temperatures around $550{ }^{\circ} \mathrm{C}$; this implies that orthopyroxene in the granulite has been significantly affected by retrograde fluids, which is supported by the oxygen isotope disequilibrium between garnet and orthopyroxene (see section 7.1.6). As shown in Fig. 7.6A, the garnet-quartz pairs used for isotopic temperature estimates are less altered and coexist very closely, representing a local bi-mineral system. It is well known that garnet is the most resistant to oxygen isotopic exchange, thus in such system isotopic exchange caused by retrograde metamorphism is unlikely. Therefore, temperatures estimated from the garnetquartz pairs should represent peak metamorphic conditions.

\subsection{Hydrogen isotope analyses of hydroxyl-bearing mineral separates from eclogite and gneiss from the SDT}

Hydroxyl-bearing mineral separates from eclogites and gneisses in the Dabie Shan, including phengite, epidote (zoisite), amphibole and biotite, were analyzed by the conventional method. Hydrogen isotope ratios are normalized to the V-SMOW-SLAP scale (O'Neil 1986), and precision is about $\pm 2 \%$. The measured $\delta \mathrm{D}$ of NBS-30 was $-62 \%$ o. Unfortunately, analyzed samples are only from the localities in the SDT, suitable mineral separates from the NDC have not been obtained.

As listed in Table 7.3 and shown in Fig. 7.7, the total range is between -105 and $55 \%$ with no difference between eclogites and gneisses. Biotite and amphiboles show more or less the same range between -105 to $-90 \%$ o. Phengites have a range from -93 to $-60 \%$. The heaviest minerals in $\mathrm{D}$ are epidotes.

Petrological observations indicate that coarse-grained phengite in eclogite occurs as a primary phase, whereas amphibole, epidote and biotite are retrograde-phase minerals. The formation temperatures of phengite are $>700{ }^{\circ} \mathrm{C}$. Secondary amphibole, epidote and biotite formed at temperatures around $450{ }^{\circ} \mathrm{C}$ (most separated minerals of amphibole, epidote and biotite in eclogite for hydrogen isotope mesurements are secondary). If the isotope fractionation behaviour of hydrogen in phengite is assumed to be close to muscovite, hydrogen isotope fractionation between phengite and water is about $-10 \%$ at temperatures of $700{ }^{\circ} \mathrm{C}$. Similarly, at temperatures around $450{ }^{\circ} \mathrm{C}$, hydrogen isotope fractionation between 
Table 7.3 Hydrogen isotope compositions of hydroxyl-bearing minerals in eclogites and gneisses from the SDT

\begin{tabular}{|c|c|c|c|c|c|c|}
\hline Locality & $\begin{array}{l}\text { Sample } \\
\text { Number }\end{array}$ & Rock type & $\begin{array}{l}\text { DD of } \\
\text { phengite }\end{array}$ & $\begin{array}{l}\delta \mathrm{D} \text { of } \\
\text { amphibole }\end{array}$ & $\delta \mathrm{D}$ of biotite & $\delta \mathrm{D}$ of epidote \\
\hline \multirow[t]{2}{*}{ Bixiling } & DB02 & eclogite & -72 & -92 & & \\
\hline & DB11 & eclogite & -64 & & & \\
\hline \multirow[t]{6}{*}{ Shuanghe } & DB33 & eclogite & & -100 & & \\
\hline & DB34 & eclogite & & & & \\
\hline & DB39 & eclogite & -85 & & & -59 \\
\hline & DB40 & eclogite & -68 & & & -53 \\
\hline & DB42 & gneiss & -93 & & -105 & -75 \\
\hline & DB43 & gneiss & -85 & $-100,-98$ & & -56 \\
\hline Shima & DB61 & & & & & \\
\hline \multirow[t]{6}{*}{ Lidu } & DB44 & eclogite & -81 & & & \\
\hline & DB45 & eclogite & -91 & & & \\
\hline & DB46 & eclogite & -80 & & & \\
\hline & DB48 & eclogite & -83 & & & -62 \\
\hline & DB55 & gneiss & & -99 & -92 & -63 \\
\hline & DB56 & gneiss & -78 & & -94 & -63 \\
\hline \multirow[t]{2}{*}{ Others } & DB20 & eclogite & & & -90 & \\
\hline & DB26 & eclogite & -62 & & & \\
\hline
\end{tabular}

biotite and water, and epidote and water are about $-45 \%$, and $-35 \%$, respectively (Sheppard, 1984). Thus, fluids responsible for the $\delta \mathrm{D}$ values of phengite would probably have $\delta \mathrm{D}$ values of about $-80 \%$, whereas fluids responsible for the $\delta \mathrm{D}$ values of biotite and epidote have $\delta \mathrm{D}$ values of about $-50 \%$ and $-25 \%$ respectively, assuming hydrogen isotope equilibrium between fluids and these minerals. The $\delta \mathrm{D}$ values of about $-80 \%$ for phengite indicate the involvement of either meteoric water, or alternatively primary magmatic water in the formation of the phengite (Hoefs, 1997). On the other hand, the $\delta \mathrm{D}$ values of about -50 and $25 \%$ suggest the presences of metamorphic water and/or meteoric water under warm climatic conditions during the formation of biotite and epidote. Since the latitudes of eastern China 
were similar at times of around $240 \mathrm{Ma}$ (the formation of phengite) and $130 \mathrm{Ma}$ (the formation of biotite and epidote, $\mathrm{Li}$ et al., 1993), it is unlikely that the different $\delta \mathrm{D}$ values of 55 to $-30 \%$ resulted from a change of climate. Therefore, the different hydroxyl-bearing minerals might have interacted with fluids of different origins.

A

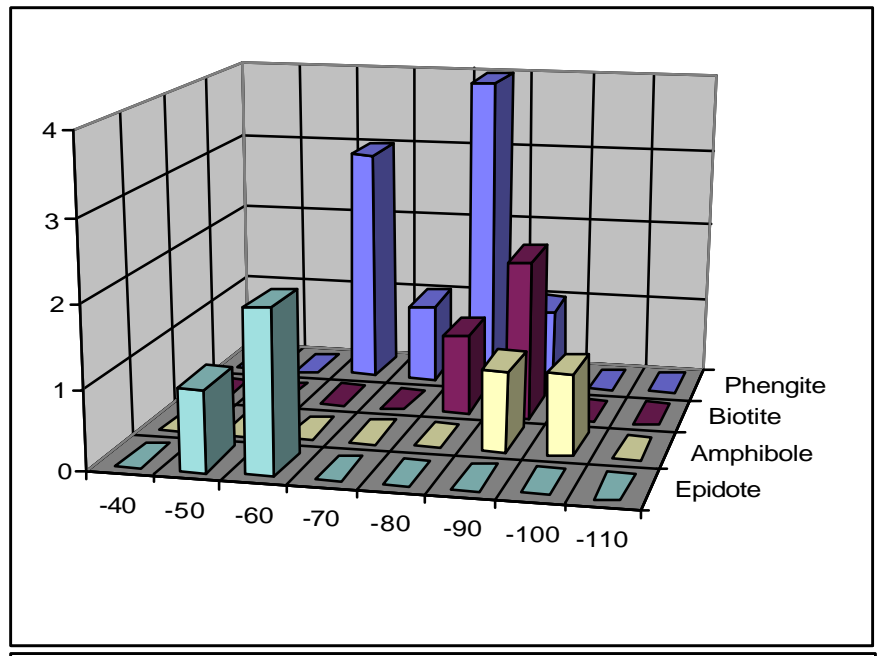

B

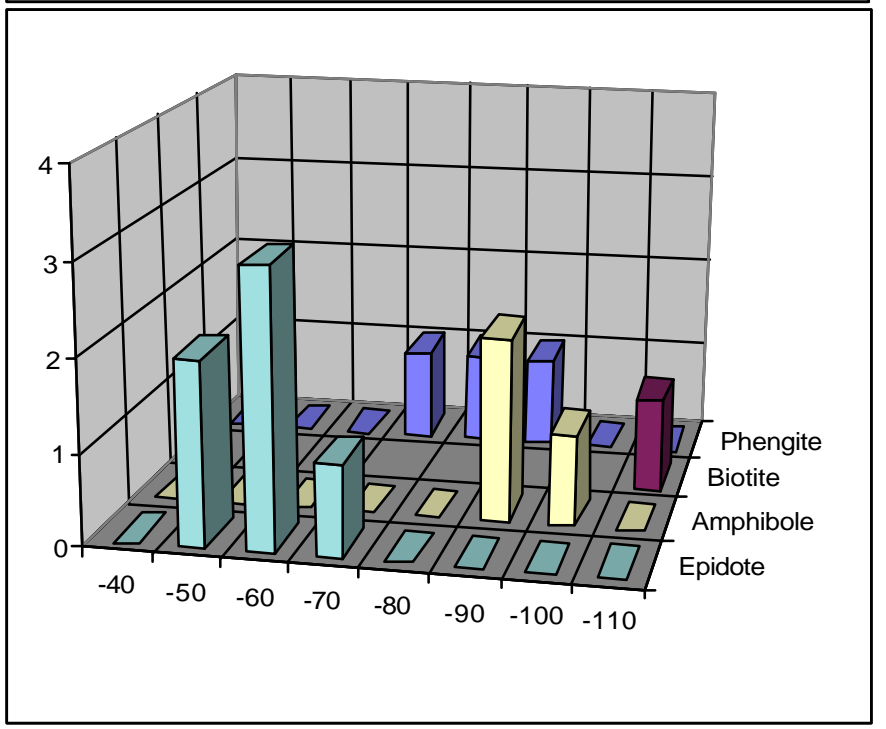

Fig.7.7 $\mathrm{DD}$ values of hydroxyl-bearing minerals in the eclogites and gneisses from Dabie Shan

Note: A: hydroxyl-bearing minerals in eclogites; B: hydroxyl-bearing minerals in gneisses

Experimental studies of hydrogen isotope exchange kinetics under hydrothermal conditions imply that muscovite (phengite) has higher closure temperatures than zoisite (epidote) (Graham, 1981). Because of the difference in the rate of hydrogen diffusion, 
phengite has probably preserved the hydrogen isotope composition of the meteoric water, whereas epidote has preserved the hydrogen isotope composition of fluids presented during retrograde metamorphism. The difference in $\delta \mathrm{D}$ values among hydroxyl-bearing minerals probably originated from differential exchange of hydrogen isotopes between phengite, amphibole, biotite, epidote and fluids.

In view of the points discussed above, hydrogen isotope data of eclogites indicate late fluids-rock interactions probably during retrograde metamorphism. The heaviest $\delta \mathrm{D}$ values of the retrograde fluid would probably close to $-20 \%$, excluding recent meteoric waters which in eastern China have $\delta \mathrm{D}$ values -40 to $-70 \%$ o (Zhang et al., 1985). 


\section{Chapter 8. METAMORPHIC EVOLUTION AND P-T CONDITIONS}

\subsection{The Bixiling eclogite}

Based on the petrographic study and microprobe data of minerals, we can deduce a multi-stage metamorphic evolution in at least five metamorphic stages for the Bixiling complex:

(1) Prograde eclogite-facies metamorphism. This stage is represented by minerals such as phengite and omphacite occurring as inclusions within garnet porphyroblasts. The K-rich rims of omphacite inclusions reflect P-T conditions of the peak metamorphism, whereas the composition of the cores reflects the conditions of prograde eclogite-facies metamorphism. The pressure at this stage is estimated to be $15-20 \mathrm{~kb}$ based on the P-T relationship of eclogitefacies metamorphism (Råheim and Green 1975). Temperatures were estimated to be 700-780 ${ }^{\circ} \mathrm{C}$ applying the garnet-clinopyroxene geothermometers of Ellis and Green (1979), Krogh (1988) and Aranovich and Pattison (1995) to the cores of the Krich omphacite inclusions and the mean composition of garnet in the retrograded eclogite.

(2) Coesite eclogite-facies metamorphism is characterized by the formation of coesite and K-rich omphacite inclusions and is considered to represent peak metamorphic conditions. Temperatures for this stage were calculated to be higher than $1000{ }^{\circ} \mathrm{C}$ (see Table 8.1). Pressure was estimated to be $>40 \mathrm{kbar}$.

(3) Recrystallized eclogite-facies metamorphism. Coarse-grained garnet and omphacite formed at this stage and have inclusions of coesite and K-rich omphacite formed during coesite eclogite-facies metamorphism. Temperatures were calculated to be $750-850{ }^{\circ} \mathrm{C}$ using the Grt-Cpx geothermometers of Ellis and Green (1979), Krogh (1988) and Aranovich and Pattison (1995) on the Cpx-Grt pairs (Table 8.1). Pressures were estimated to be 15-20 kbar (Råheim \& Green, 1975). This stage probably represents an initial retrograde metamorphism of the eclogites during early uplift.

(4) Retrograde symplectite stage is represented by the symplectitic replacement assemblage of clinopyroxene, amphibole and plagioclase. This stage probably corresponds to high-grade amphibolite-facies conditions. Temperatures of $600-700{ }^{\circ} \mathrm{C}$ were estimated using amphibole-clinopyroxene geothermometry (Perchuk 1969), and pressures of 9-12 kbar were calculated based on the geobarometer of Kohn and Spear (1990).

(5) Retrograde amphibolite-facies stage. Coarse-grained amphiboles that occur as kelyphitic rims of garnet and symplectite, biotite retrograded from phengite, and coarsegrained epidote and plagioclase are the characteristic minerals of this stage and indicate 
epidote-amphibolite-facies metamorphism. Application of amphibole-plagioclase geothermometry (Perchuk 1966; quoted from Zhang and Cong 1983) yields temperatures between $400^{\circ} \mathrm{C}$ and $450^{\circ} \mathrm{C}$ at $5 \mathrm{kbar}$. The pressure estimated by $\mathrm{Al}{ }^{\mathrm{IV}} / \mathrm{Al}^{\mathrm{VI}}$ of amphibole is $\sim 5$ kbar (Raase 1974).

\subsection{The Shima eclogite}

Eclogite from Shima is less altered compared to the other studied samples. Only two metamorphic stages were distinguished based on petrographic observations.

(1) Coesite eclogite-facies metamorphism. The eclogite from Shima contains relict coesite as inclusions in garnet (Wang et al., 1989), indicating it has been subjected to a pressure of $>29 \mathrm{kbar}$ at a temperature of $800{ }^{\circ} \mathrm{C}$ based on the equilibrium of coesite $=$ quartz (Bohlen and Boettcher, 1982). It is generally assumed that coesite inclusions in garnet and omphacite are representative of peak metamorphic conditions for the eclogite assemblages and can be used as the minimum pressure indicator (e.g. Chopin, 1984; Smith, 1984). The peak metamor phic temperatures for this stage were calculated by Xiao (1991) to be about 830 ${ }^{\circ} \mathrm{C}$ at pressures of $30 \mathrm{kbar}$.

(2) Recrystallized eclogite-facies metamorphism. In addition to coesite, the Shima eclogite contains a high-pressure assemblage of coarse-grained garnet, omphacite and rutile. The jadeitic content of omphacite $(>40 \%)$ indicates that the eclogite has been subjected to a minimum pressure of $15 \mathrm{kbar}$ at $700{ }^{\circ} \mathrm{C}$. Metamorphic temperatures have been calculated to be about $690{ }^{\circ} \mathrm{C}$ (Xiao, 1991).

\subsection{The Shuanghe jadeite quartzite}

The UHP slab in Shuanghe has been well studied (e.g., Cong et al., 1995; Okay, 1993; Liou et al., 1997). Similar to the adjacent UHP eclogites in Shuanghe, which have undergone a complex metamorphic evolution (Cong et al., 1995), the jadeite quartzite also has been subjected to a multiple metamorphism:

(1) Coesite-eclogite facies metamorphism. The formation of coesite is the characteristic process of this stage, which represents the peak metamorphism for the Shuanghe jadeite quartzite. Coesite relics, preserved as inclusions within jadeite, indicate that peak metamorphic pressures of $>29 \mathrm{kbar}$ (at temperature $=800{ }^{\circ} \mathrm{C}$ ) were reached. Although Liou et al. (1997) suggested peak metamorphic temperatures of $670 \pm 30{ }^{\circ} \mathrm{C}$ for this stage, they obtained up to $910{ }^{\circ} \mathrm{C}$ using Powell's (1985) calibrations for the core compositions for both garnet and jadeite; Cong et al. (1995) got 700-950 ${ }^{\circ} \mathrm{C}$ for the Jd-rich omphacite 
inclusions in garnet. Similarly, high temperatures of above $1000{ }^{\circ} \mathrm{C}$ have been obtained using the measured compositions and the Grt-Cpx thermometers of Aranovich and Pattison (1995), Krogh (1988) and Ellis and Green (1979) (total Fe was assumed to be $\mathrm{Fe}^{2+}$ ); oxygen isotope thermometers for the Qz-Grt and Qz-Jd pairs yield temperatures ranging from 800 to $1000{ }^{\circ} \mathrm{C}$ (see Table 7.2). Thus, a peak temperature of $>800{ }^{\circ} \mathrm{C}$ was assumed for the jadeite quartzite in Shuange.

(2) Recrystallized eclogite-facies metamorphism. During this stage, coesite was replaced by polycrystalline quartz aggregates, corresponding to Cong's et al. (1995) quartzeclogite stage (III-1). The metamorphic conditions were estimated to be $\mathrm{P}>18-20 \mathrm{kbar}$ at temperatures $>700^{\circ} \mathrm{C}$.

(3) Retrograde symplectite stage. In this stage, kelyphitic coronas developed around margins of garnet and jadeite grains. The early-formed coronas are composed mainly of oligoclase and taramitic amphibole. Liou et al. (1997) have calculated that the formation of oligoclase took place at $14-18 \mathrm{kbar}$ and about $550-600{ }^{\circ} \mathrm{C}$, representing the metamorphic P-T conditions of this stage.

\subsection{The Lidu eclogite}

It is generally believed that compositional zonations in garnet reflect changing of P-T conditions (e.g. Spear, 1993). Based on the microprobe data, a three-stage growth model for garnet in the Lidu eclogite is postulated: an original core with relatively low $-\mathrm{Mg}$ and high-Ca contents represents the earliest stage of garnet growth; the low $-\mathrm{Mg}$ and high-Ca contents of the garnet core indicate that the core formed at a relatively low metamorphic grade (e.g. Lang, 1996). Hydroxyl-bearing minerals in the central zone of garnet represent the second stage, which possibly reflects a temporary decompression (e.g. temporary uplift); due to this decompression, cracks developed in some garnets (the presence of abundant cracks in the central zone of garnet grains supports this assumption); as the pressure was below the stability of garnet, garnets might be partly dissolved because of interactions with fluids resulting in the formation of hydroxyl-bearing minerals. Fluid/rock interactions also resulted in an increase of $\delta^{18} \mathrm{O}$ values in the central zone of some garnets in which garnet has not been replaced by hydroxyl-bearing minerals. In a third stage, pressure increases again, which probably resulted from a re-subduction of the slab, garnet grew again and peak metamorphic conditions reached eclogite-facies metamorphism; rim and late-formed core of garnets probably formed at this stage. 
Based on these petrographic observations, six metamorphic stages may be distinguished:

(1) Early prograde metamorphism. Epidote, rutile and phengite occur as inclusions in the core of some garnets. This assemblage indicates that mineral inclusions in the garnet core formed under relatively low-pressure and temperature conditions. However, quantitative P-T estimates for this stage are impossible because of the absence of suitable mineral pairs.

(2) The first peak metamorphism. Omphacite and phengite occur as inclusions in the central zones of some garnets. The presence of a few omphacite inclusions suggests that the eclogite underwent prograde eclogite-facies metamorphic conditions. Jd content in omphacite inclusions is lower than that in matrix omphacite grains (see Table 4.1), indicating lower pressures for the omphacite inclusions. The early garnet core (see Fig. 4.8) might form at this stage. Metamorphic temperatures for this stage were estimated using the pyroxene-garnet geothermometers of Ellis and Green (1979), Krogh (1988) and Aranovich and Pattison (1995) for coexisting omphacite inclusions and host garnet; pressures were estimated using jadeitecontent of omphacite inclusions (Holland, 1980). The obtained results are: $\mathrm{T}=600-650{ }^{\circ} \mathrm{C}$ and $\mathrm{P}>15$ kbar.

(3) An early temporary retrograde metamorphic stage. During this stage, due to a pressure decrease, some garnets partly interacted with fluids and thus formed the snow-ball texture of hydroxyl-bearing minerals in the central portion of garnet.

(4) The peak metamorphic stage. Regrowth of the garnet core and margin may indicate an increase of pressure. Such increase of pressure probably originated from a re-subduction after the temporary uplift. Thus we assume that the regrowth of the garnet core and the margin formed during this stage. The absence of coesite inclusions indicates that the maximum metamorphic pressure of the eclogite from Lidu should be below the stability of coesite. However, the coexistence of kyanite + omphacite in the matrix indicates minimum pressures, which are constrained by the equilibrium of paragonite $=$ kyanite + omphacite + $\mathrm{H}_{2} \mathrm{O}$ to be about $20 \mathrm{kbar}$ (Holland, 1979; Newton, 1986). Higher jadeite contents in matrix omphacite compared to those in omphacite inclusions also indicates higher pressures. Peak temperatures of $650-700{ }^{\circ} \mathrm{C}$ have been estimated from the $\mathrm{Fe}-\mathrm{Mg}$ exchange of Grt-Cpx geothermometers (Ellis and Green, 1979; Krogh, 1988; Aranovich and Pattison, 1995) based on an assumed pressure of $20 \mathrm{kbar}$, using the compositions of matrix omphacite and of the garnet rim. This temperature region agrees very well with that estimated from oxygen isotope thermometers (Table 7.2), but is 50-100 ${ }^{\circ} \mathrm{C}$ higher than Wang et al. (1992) suggested. 
5) Retrograde symplectite stage. After the peak metamorphic stage, the eclogite began to uplift again. The P-T conditions of this stage are well constrained by the hydrothermal breakdown of paragonite ? albite + corundum + water (see Fig. 4.2) to be $=630{ }^{\circ} \mathrm{C}$ at $7 \mathrm{kbar}$ (Deer et al., 1992). As corundum being the stable phase above about $450{ }^{\circ} \mathrm{C}$ (Deer et al., 1992), the temperature range of this stage should be $450-630^{\circ} \mathrm{C}$. Another obvious feature for this stage are symplectites after omphacite and garnet.

(6) Retrograde amphibole-facies metamorphism stage. Secondary epidote, amphibole, and sodic plagioclase occur as kelyphitic rim of omphacite and garnet. This assemblage points to a retrograde epidote-amphibolite facies metamorphism.

\subsection{The Raobazhai eclogite}

At least four metamorphic stages can be deduced for the metamorphic evolution of the Raobazhai complex based on petrographic studies and microprobe analyses. The $P-T$ conditions of metamorphic recrystallization for the four metamorphic stages were estimated using various thermobarometers.

(1) Peak pressure eclogite-facies metamorphism. The peak metamorphic stage is represented by the core compositions of pyroxene and garnet. The preservation of an omphacitic core in the zoned pyroxene indicates that the peak pressure metamorphic stage corresponds to eclogite facies metamorphism. The lower limit of the peak metamorphic pressure is estimated to be $18.5 \mathrm{kbar}$ at $750{ }^{\circ} \mathrm{C}$ according to the jadeite contents in the omphacitic core of the pyroxenes (c. $30 \mathrm{~mol} \%$ ) using the barometer of Holland (1980). Tsai \& Liou (2000) suggested a very high metamorphic pressure for the Raobazhai complex (>25 kbar). However, as we did not find any excess $\mathrm{SiO}_{2}$ in $\mathrm{Ca}-\mathrm{Na}$ clinopyroxene (see Tasi \& Liou, 2000) from our samples, we assume that the pressure of $18.5 \mathrm{kbar}$ is the lower limit of the peak metamorphic pressure of Raobazhai complex. Temperature estimates for this stage (core-core parts for the pyroxene and garnet) at $20 \mathrm{kbar}$ based on the Grt-Cpx thermometers of Aranovich and Pattison (1995), Krogh (1988) and Ellis and Green (1979) are in the range 680 to $860{ }^{\circ} \mathrm{C}$.

(2) Recrystallized eclogite facies metamorphism. The decrease of jadeite contents in pyroxene from the core towards the rim indicates a retrograde compression. The application of Holland's (1980) barometer for the diopside or augite rims yields pressures from 14 to 17 kbar. The application of the three thermometers (Aranovich and Pattison 1995; Krogh 1988 and Ellis and Green, 1979) to the rim-rim compositions of the coexisting garnet and pyroxene at $15 \mathrm{kbar}$ give temperatures ranges of 820 to $1000^{\circ} \mathrm{C}$. 
(3) Retrograde granulite facies metamorphism. The overgrowth of hypersthene at the rims of some pyroxene grains indicates that the Raobazhai complex underwent a retrograde metamorphism from recrystallized eclogite facies to granulite facies conditions. The formation of the overgrowth hypersthene can be expressed by the following decompression reaction:

$$
\text { garnet }+ \text { clinopyroxene }+\mathrm{SiO}_{2}=\text { orthopyroxene }+ \text { plagioclase }
$$

The coexistence of orthopyroxene, plagioclase and the rim of clinopyroxene (Fig.4.3b) supports this explanation. The metamorphic pressure for the retrograde granulite facies metamorphic stage is estimated to be c. 7 kbar at $900{ }^{\circ} \mathrm{C}$ using the $\mathrm{Al}$ content in the overgrowth hypersthene employing the barometer of Harley (1984), whereas the application of the Fe-Mg exchange thermometer of Grt-Opx (Lee and Ganguly, 1988) yields temperatures between 900 and $950^{\circ} \mathrm{C}$ at $7 \mathrm{kbar}$.

(4) Retrograde amphibolite facies metamorphism. Secondary amphibole and plagioclase are the characteristic mineral assemblage. The metamorphic pressures are estimated to be $<5$ kbar based on the relation between $\mathrm{Al}^{\mathrm{VI}}$ and $\mathrm{Si}$ of amphibole (Raase, 1974). The amphibole-plagioclase thermometer of Blundy and Holland (1990) yields metamorphic temperatures ranging from 800 to $850{ }^{\circ} \mathrm{C}$, which is in good agreement with the temperature estimates for the amphibolites and amphibolite facies gneisses from the northern Dabie Shan using the same thermometer by Zhang et al. (1996), and also corresponds to the fact that amphiboles in the studied samples usually contain high $X_{\mathrm{Ti}}$ (Raase, 1974).

\subsection{The Yanzihe granulite}

A two-stage metamorphic evolution can be assumed for the granulite from the Yanzihe area: garnet porphyroblasts, matrix hypersthene and quartz record granulite-facies conditions, whereas secondary amphibole is assumed to represent the retrograde amphibolitefacies metamorphism. The P-T conditions of metamorphic recrystallization for the two metamorphic stages were estimated using various thermometers.

Metamorphic pressures of the granulite-facies metamorphism were estimated to be > 11 kbar using the Grt-Opx barometers of Wood and Banno (1973) and the Al content in the orthopyroxene (Harley, 1984). The absence of plagioclase indicates that the studied granulite might have been subjected to a metamorphic pressure of $\sim 13 \mathrm{kbar}$ at $800{ }^{\circ} \mathrm{C}$ or $\sim 15 \mathrm{kbar}$ at $1000{ }^{\circ} \mathrm{C}$ according to the plagioclase-out curve from Green and Ringwood (1967). Application of the Fe-Mg exchange thermometer of Grt-Opx (Lee and Ganguly, 1988) yields temperatures between 750 and $800{ }^{\circ} \mathrm{C}$ at pressure of $10 \mathrm{kbar}$. This temperature range is about 
$200{ }^{\circ} \mathrm{C}$ lower than that estimated from Grt-Qz oxygen isotope thermometer (Table 7.2), and also $50-100{ }^{\circ} \mathrm{C}$ lower than the temperature estimates of the subsequent retrograde amphibolite-facies metamorphism. This discrepancy in temperature estimates may be related to the effects of retrograde metamorphism, as discussed in section 7.2. It should be mentioned that the application of the two thermometers yield good agreement for the other localities (see also Zheng et al. 1998, 1999). Considering the granulite-facies metamorphic temperatures in Raobazhai (see also Xiao et al., 2001), a similar temperature of $900{ }^{\circ} \mathrm{C}$ is suggested for this stage.

Based on the relation between $\mathrm{Al}^{\mathrm{VI}}$ and $\mathrm{Si}$ of amphibole (Rasse, 1974), pressures of about 5 kbar have been suggested for the formation of the amphibole in the granulite. The garnetamphibole geothermometer (Graham and Powell, 1984) in secondary amphiboles within garnet in veins gives temperatures of around $850{ }^{\circ} \mathrm{C}$. This result is in good agreement with the temperature estimates for the amphibolite-facies metamorphism of Raobazhai using amphibole-plagioclase thermometer of Blundy and Holland (1990), and is also consistent with the metamorphic temperatures estimated for the amphibolites and amphibolite-facies gneisses in the NDC by Zhang et al. (1996).

\subsection{Summary of P-T calculations}

P-T conditions for the investigated samples are summarized in Table 8.1 and shown in Fig. 8.1.

Table 8.1 P-T estimates of investigated samples from Dabie Shan. Thermobarometries applied for pressure and temperature calculations see text.

\begin{tabular}{|c|c|c|c|c|c|c|c|c|c|c|}
\hline \multirow[t]{2}{*}{ Locality } & \multicolumn{2}{|c|}{$\begin{array}{l}\text { Prograde } \\
\text { metamorphism }\end{array}$} & \multicolumn{2}{|c|}{$\begin{array}{l}\text { Peak (pressure) } \\
\text { metamorphism }\end{array}$} & \multicolumn{2}{|c|}{$\begin{array}{l}\text { Recrystallized } \\
\text { metamorphism }\end{array}$} & \multicolumn{2}{|c|}{$\begin{array}{l}\text { retrograde } \\
\text { stage (I) }\end{array}$} & \multicolumn{2}{|c|}{$\begin{array}{l}\text { retrograde } \\
\text { stage (II) }\end{array}$} \\
\hline & $\mathrm{P}(\mathrm{kbar})$ & $\mathrm{T}\left({ }^{\circ} \mathrm{C}\right)$ & $\mathrm{P}$ (kbar) & $\mathrm{T}\left({ }^{\circ} \mathrm{C}\right)$ & $\mathrm{P}$ (kbar) & $\mathrm{T}\left({ }^{\circ} \mathrm{C}\right)$ & $\mathrm{P}$ (kbar) & $\mathrm{T}\left({ }^{\circ} \mathrm{C}\right)$ & $\mathrm{P}$ (kbar) & $\mathrm{T}\left({ }^{\circ} \mathrm{C}\right)$ \\
\hline \multicolumn{11}{|c|}{ SDT } \\
\hline Bixiling & $15-20$ & $\begin{array}{l}700- \\
780\end{array}$ & $>40$ & $\sim 1000$ & $15-20$ & $\begin{array}{c}750- \\
850\end{array}$ & $9-12$ & $\begin{array}{l}600- \\
700\end{array}$ & $\sim 5$ & $\begin{array}{l}400- \\
450\end{array}$ \\
\hline Shima & & & $>30$ & $\sim 830$ & $>15$ & 700 & & & & \\
\hline Shuanghe & & & $>30$ & $\sim 800$ & $18-20$ & $>700$ & $14-18$ & $\begin{array}{c}550- \\
600\end{array}$ & & \\
\hline Lidu & $\sim 15$ & $\sim 650$ & $\sim 20$ & $\begin{array}{l}650- \\
700\end{array}$ & & & 7 & $\begin{array}{l}450- \\
630\end{array}$ & & \\
\hline \multicolumn{11}{|c|}{ NDC } \\
\hline Raobazhai & & & $>18.5$ & $\begin{array}{c}680- \\
860\end{array}$ & 15 & $\begin{array}{l}820- \\
1000\end{array}$ & 7 & $\begin{array}{c}900- \\
950\end{array}$ & $\sim 5$ & $\begin{array}{l}800- \\
850\end{array}$ \\
\hline Yanzihe & & & $13-15$ & $\sim 900$ & & & & & $\sim 5$ & $\begin{array}{l}800- \\
850\end{array}$ \\
\hline
\end{tabular}




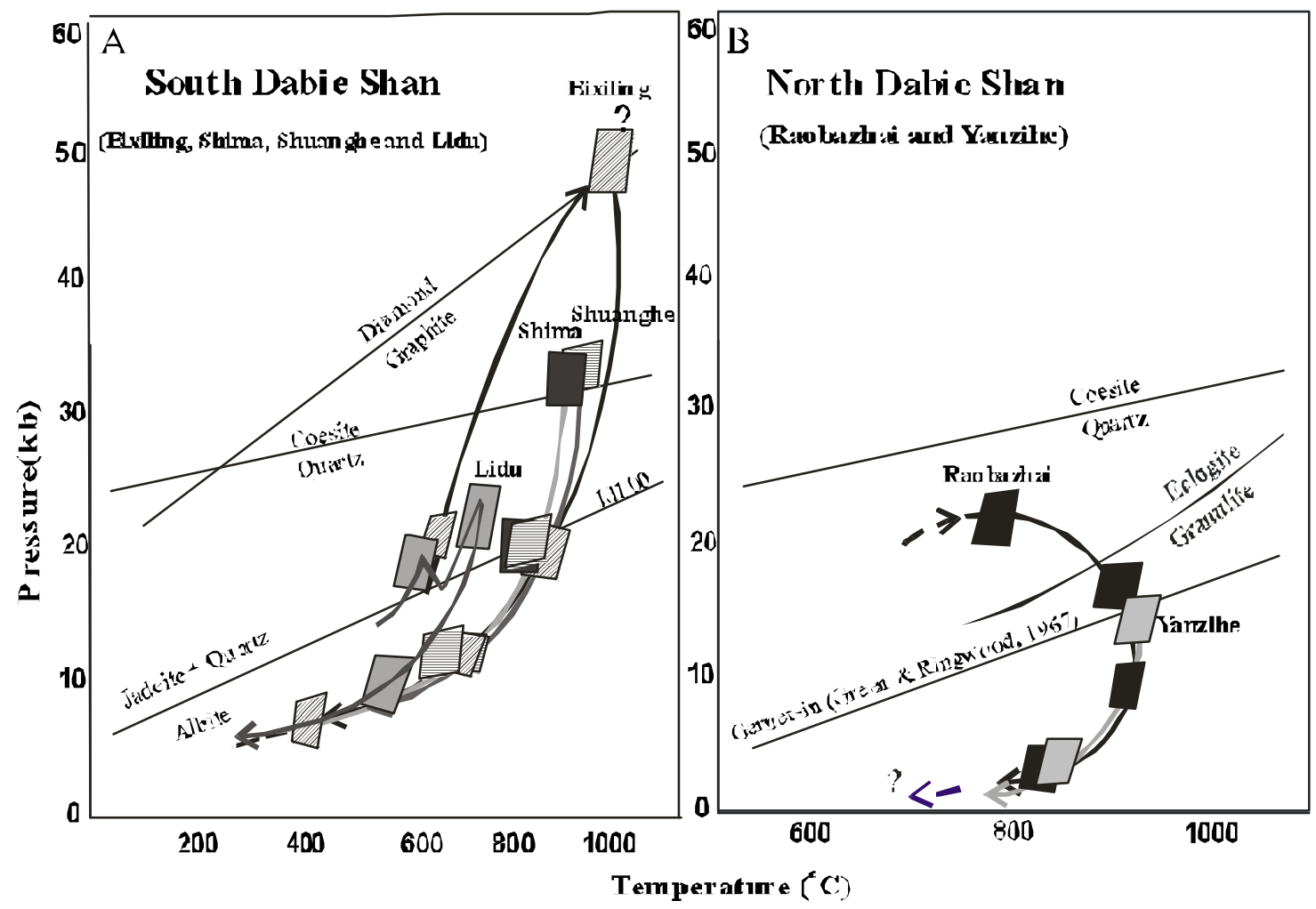

Fig. 8.1. Summary of the P-T paths generated from various thermobarometer calculations for the investigated rocks. Data sources: jadeite +quartz = albite (Holland, 1980); coesite=quartz (Bohlen and Boettcher, 1982); diamond = graphite (Kennedy and Kennedy, 1976); the eclogite to granulite transition is after Green and Ringwood (1967). For explanations see text. 


\section{Chapter 9. DISCUSSION}

\subsection{Contrasting P-T paths between the metamorphic rocks from the SDT and NDC}

Two important observations emerge from an inspection of the metamorphic P-T estimates:

(1) The estimated peak P-T conditions for the four localities from the SDT show a consistent trend from $\sim 700{ }^{\circ} \mathrm{C}, 20 \mathrm{kbar}$ in the Lidu area in the south of the SDT, 800-850 ${ }^{\circ} \mathrm{C}$, $>29 \mathrm{kbar}$ in the Shuanghe and Shima areas, to $\sim 1000{ }^{\circ} \mathrm{C},>40 \mathrm{kbar}$ in the Bixiling area in the northern part of the SDT. Wang et al. (1992) presented similar trends for the other eclogite localities in the SDT. Metamorphic rocks in the northern margin of the SDT have been subjected to much higher metamorphic P-T conditions than those in the southern margin, or in other words, rocks from the North (e.g. Bixiling) may have been subducted to much greater depth than those in the South of the SDT. This trend may indicate the subduction direction of the Yangtze craton.

(2) During the stage of initial uplift (from peak to recrystallized eclogite-facies) of the metamorphic rock in the NDC, especially in Raobazhai, there is a significant temperature increase (Fig. 8.1b). The P-T paths in the NDC are therefore quite different compared to the retrograde $P-T$ paths of the UHP eclogite from the SDT, in which all the localities show nearly isothermal decompression paths following the maximum pressure (Fig. 8.1a) (see also Wang et al., 1992; Okay, 1993; Xiao \& Li, 1993; Xiao et al., 1995). Eclogites formed in deep parts of typical continent-continent collision zones, as in the Tauern Window, Austria, usually show P-T paths in which the metamorphic peak temperature is synchronous with the maximum pressure and along a nearly isothermal decompression path (Spear, 1989). On the other hand, for eclogites formed in subduction zones, many subduction P-T paths show that the maximum pressure is often followed by a decompression path with substantial heating (Spear, 1993). In any case, the initial retrograde P-T path indicates that the NDC might be related to another tectonic environment.

Furthermore, peak metamorphic pressures and temperatures of the two tectonic units are also different. There is now abundant evidence that the SDT and the Sulu areas were subjected to peak metamorphic pressures up to $50 \mathrm{kbar}$ or even to $70 \mathrm{kbar}$, mich higher than former estimates of $30 \mathrm{kbar}$ based on the stability of coesite (Zhang et al., 1995; Green et al., 1997; Xiao et al., 2000; Ye et al., 2000). In contrast, the evidence for pressures >30 kbar in the NDC is not straight forward. Most workers have argued that the NDC was subjected to 
peak pressure < 25 kbar (e.g., Wang and Liou, 1991; Li et al., 1993; Zhang et al., 1996). Although one might postulate that UHP indicator minerals in the NDC might have been obliterated by the granulite-facies retrograde event, this seems to be unlikely because coesite inclusions are also abundant in strongly granulitized eclogites in Sulu (e.g., Wang et al., 1993; Nakaruma and Hirajima, 2000; Yao et al., 2000), even some of them have been subjected to significant fluid/rock interactions during metamorphism (e.g. Jahn et al., 1996). As discussed below, the very low water activity during peak metamorphism of the NDC provided the essential environment for the preservation of UHP index minerals (if any).

Therefore, the contrasting P-T features require that the two tectonic units, the SDT and the NDC, had separate histories. In other words, they might belong to the Yangtze and North China cratons respectively before the Triassic continent-continent collision. The relatively high temperature and low pressure of the rocks in the NDC in comparison with the SDT suggest that the NDC is not a thrust plane in the subducted continental crust of the Yangtze craton as proposed by Okay and Sengör (1993) and Maruyuma et al. (1994). On the other hand, 2-stage models suggest initial rapid exhumation until about $40 \mathrm{~km}$ in depth for the UHP metamorphic rocks in the SDT (Xiao, 1991; Li et al., 1993; Xiao et al., 1995; Chavagnac and Jahn, 1996; Xue et al., 1996). Li et al. (2000) showed that the UHP metamorphic rocks in Shuanghe cooled down to $500{ }^{\circ} \mathrm{C}$ at $219 \pm 7$ Ma by an initial rapid cooling, which corresponds to the retrograde symplectite stage with pressures of about $6-8 \mathrm{kbar}$. It is thus possible that the SDT containing the UHP metamorphic rocks reached greater depths (e.g. $>120 \mathrm{~km}$ ?) during subduction and exhumed rapidly to shallow levels, whereas the NDC, containing the hotter eclogites and granulites, reached relatively less depths (e.g. $<80 \mathrm{~km}$ ?) but stayed longer. Such an evolution wald be consistent with a thermal event leading to the granulite- facies overprint in the NDC described here but, until the granulite-facies stage in these rocks has been dated, this remains speculation.

\subsection{Fluid compositions during the metamorphic evolution of the rocks from Dabie Shan}

Fluid inclusions in metamorphic minerals represent a unique opportunity to detect the composition of the fugitive volatile phase and to determine the pressure-temperature-volume relations of fluids of different compositions. The fluid inclusion assemblage of a metamorphic rock is the result of a series of fluid/rock interaction processes at different stages of its P-T history. Different types of fluid inclusions within various minerals reflect fluids trapped at different metamorphic stages of a rock. 
In Bixiling, as kyanite is a primary phase formed during peak metamorphism (Zhang et al., 1995), the Carich brines in quartz blebs in kyanite are assumed to represent the earliest recognizable fluid and originated from prograde metamorphism. Although minor amounts of $\mathrm{CO}_{2}$ have been found in these fluids, $\mathrm{CO}_{2}$ appeared to be not important during the prograde metamorphism. For the Ca-enrichment in these fluids, a possible explanation is the exchange of cations between plagioclase and a chloride-rich fluid. Textures related with high-salinity NaCl-dominated fluid inclusions in omphacite, kyanite and matrix quartz suggest that the fluid inclusions were trapped during the peak of metamorphism. Despite isochore calculations have shown that the primary NaCldominated high-salinity inclusions in omphacite and kyanite only approach the lower limit of the eclogite-facies P-T field, it is believed that fluid inclusion data in such metamorphic rocks, when combined with mineral analysis and textural observations, give information about the fluid composition during high-pressure metamorphism (e.g. Philippot and Selverstone, 1991; Selverstone et al., 1992; Touret 1992; Philippot et al., 1995; Touret and Huizenga, 1999).

The textural evidence of the high-salinity aqueous inclusions in quartz from Shima suggest that these inclusions are of primary origin and were trapped during the peak metamorphism of the UHP eclogite. Thus, similar to the case of Bixiling, high salinity solutions were present during peak metamorphic conditions of the Shima eclogite. The fluid phase present during the prograde and peak metamorphism of the jadeite quartzite from Shuanghe was dominated by water-rich solutions; it evolved, however, towards mixtures of $\mathrm{CO}_{2}$ and $\mathrm{H}_{2} \mathrm{O}$ during late retrograde metamorphism. The fact that only secondary waterdominated inclusions have been observed in the 'cold' eclogite from Lidu indicates open system conditions during garnet-grade metamorphism. This conclusion is supported by the oxygen isotope data (see below section 9.4.4).

For metamorphic rocks from the NDC, high-salinity inclusions $\pm \mathrm{N}_{2}$ in garnet cores are the recognizable earliest generation of fluid inclusions and may represent fluid compositions of the peak metamorphism (eclogite facies) of the eclogite from the Raobazhai complex. Carbonic inclusions in the garnet rims are assumed to have been trapped during granulite facies retrogression and thus represent the compositions of the fluid system during granulite facies metamorphism. Secondary low-salinity inclusions in garnet imply that the rock interacted with an external low-salinity fluid during retrograde metamorphism. Because these inclusions occur in healed fractures, they should be trapped after garnet growth, probably after the retrograde amphibolite-facies metamorphic stage. 
The granulite from Yanzihe shows a $\mathrm{CO}_{2}$-dominated fluid phase with minor $\mathrm{N}$ and/or $\mathrm{CH}_{4}$ throughout its metamorphic evolution. However, the water activity was somewhat variable during different metamorphic stages. The fluids evolved from $\mathrm{CO}_{2}$-rich (with variable water contents) during prograde metamorphism towards almost pure $\mathrm{CO}_{2}$ fluids (without visible water) during granulite-facies metamorphism. During retrograde metamorphism, the solutions became relatively water-rich again, but with less $\mathrm{N}_{2}$ and/or $\mathrm{CH}_{4}$ compared to the prograde- and peak-metamorphism.

Since the discovery of $\mathrm{CO}_{2}$-rich fluid inclusions in granulite facies rocks, numerous studies have shown that $\mathrm{CO}_{2}$-dominated fluid inclusions are a characteristic feature of these rocks worldwide (e.g., Touret, 1981; Lamb et al., 1987; Vry and Brown, 1991). Experimental phase equilibria investigations (Santosh, 1991) indicated that regardless of the mechanism of granulite formation in different terrains, $\mathrm{CO}_{2}$ plays a critical role in buffering the fluid composition and stabilizing the dry mineral assemblages in granulite, being in accordance with the fact that occasionally orthopyroxene overgrew at the margin of the compositionally zoned pyroxene from Raobazhai ( see Fig. 4.3b). The fluid inclusion data indicate that granulite-facies metamorphism was a major event in the NDC, although some rocks reached eclogite-facies metamorphism.

In summary, our data demonstrate different fluid compositions between the SDT and NDC areas:

(1) Fluids in the rocks from the SDT are characterized by water-rich solutions with various salinities. They generally evolved from highly concentrated $\mathrm{Ca}$ (Mg)-rich brines (prograde metamorphism) towards $\mathrm{NaCl}$ dominated solutions (UHP metamorphism) and lowsalinity aqueous fluids during late retrograde uplift. The UHP jadeite quartzite from Shuanghe shows a somewhat different picture with low-salinity fluids during peak metamorphism (although a few inclusions have final melting temperatures close to $-10{ }^{\circ} \mathrm{C}$ ). The difference may be related to their protoliths; because the protolith of the jadeite quartzite was a metasedimentary rock as discussed in section 5.3 (see also Liou et al., 1997), it should be relatively water-rich compared to the igneous protoliths of the eclogites. Furthermore, some eclogites adjacent to the jadeite quartzite have high-salinity solutions during their peak metamorphism (Fu et al., 2000), supporting the above conclusion. Oxygen isotope data suggest a meteoric water-rock interaction prior to subduction for all metamorphic rocks in the SDT (see below).

(2) In contrast, metamorphic fluid phases in metamorphic rocks from the NDC are dominated by $\mathrm{CO}_{2}$-rich fluids, although some $\mathrm{N}_{2}$-bearing high-salinity and secondary waterrich inclusions have been observed in the eclogite from Raobazhai. Oxygen isotope data 
indicate that, unlike the case of the SDT, metamorphic rocks in the NDC might not have been subjected to a meteoric water-rock interaction before metamorphosis, but underwent an extensive retrograde fluid-rock interaction during uplift.

\subsection{P-T-t-fluid paths of the metamorphic rocks in the SDT and the NDC}

$\mathrm{Sm}-\mathrm{Nd}$ mineral isochron and $\mathrm{U}-\mathrm{Pb}$ zircon ages have documented a narrow age range of 210 to $230 \mathrm{Ma}$ for the peak metamorphism of the UHP rocks in the SDT (e.g., Li et al., 1992, 1993; Ames et al., 1993, 1996; Xiao et al., 1995; Chavagnac and Jahn, 1996; Rowley et al., 1997; Hacker et al., 1998). $\mathrm{Rb}-\mathrm{Sr}$ and ${ }^{40} \mathrm{Ar} /{ }^{39} \mathrm{Ar}$ thermochronologies have revealed similar cooling histories for these rocks (e.g. Chen et al., 1993; Xaio et al., 1993; Eide et al., 1994; Hacker and Wang, 1995; Li et al., 2000). However, the timing of the peak metamorphism in the NDC has been a topic of controversy.

It is known that the NDC consists of orthogneiss, migmatite, metasediments, amphibolite, granulite and mafic-ultramafic rocks. Processes that have significantly shaped the metamorphic history of the NDC include eclogite-, granulite-, amphibolite-facies metamorphism, plutonism of the orthogneissic protolith, and late granite and mafic-ultramafic magmatism. The occurrence of granulite and granulitized eclogites (e.g. Raobazhai) is a prominent characteristic in the NDC compared to the SDT.

Recently, Xue et al. (1997) and Hacker et al. (1998) reported zircon ages with arange of 125-138 Ma for a viariety of lithological units of the NDC, including orthogneiss, gabbro, tonalite intrusions, granitic gneiss and undeformed granite. Based on these ages, Hacker et al. (1998) suggested that the bulk of the NDC (>90\%) is a Cretaceous magmatic complex, and the pre-Cretaceous 'basement' rocks, represented by granulite with minor marble and ultramafic rocks, are only scraps of the Yangtze craton that survived deep subduction. However, Jahn et al. (1999b) argued that the apparent absence of subduction processes is incompatible with the formation of extensive orthogneisses if they are indeed of Cretaceous age. Li et al. (1998) also suggested that the NDC is an uniform old metamorphic terrain.

The best estimate of the peak metamorphic age for the NDC comes from Sm-Nd minerat (garnet and clinopyroxene) whole rock isochron ages, which gave $244 \pm 11 \mathrm{Ma}$ on a eclogite from Raobazhai ( $\mathrm{Li}$ et al. 1993). As has been demonstrated that garnet and pyroxene from Raobazhai are compositionally zoned, one may argue that this age probably represents a mixed age between the eclogite- and granulite facies metamorphism. However, Li et al. (1993) emphasized that all mineral separates have been obtained by careful hand-picking. 
From the semiquantitative mapping of the zoned pyroxene (see Fig. 4.13), it is obvious that the omphacitic core and diopside represent $99 \mathrm{vol} \%$ of the grains, although minor overgrowths of orthopyroxene and fine-grained plagioclase occur along the rim and in the core respectively. Furthermore, retrograde temperatures of granulite facies metamorphism are up to $900{ }^{\circ} \mathrm{C}$ (Fig. 8.1b), which may cause doubts whether the peak metamorphic ages have been reset. Closure temperatures of $850-900{ }^{\circ} \mathrm{C}$ for the $\mathrm{Sm}-\mathrm{Nd}$ system in garnet were suggested by Cohen et al. (1988) and Jagoutz (1988), whereas a much lower temperature around $600{ }^{\circ} \mathrm{C}$ was proposed by Bohlen et al. (1985) and Mezger et al. (1992). For the Raobazhai eclogite, consisting only of garnet and pyroxene during eclogite- and granulite facies metamorphism, diffusion of $\mathrm{Sm}-\mathrm{Nd}$ in garnet is mainly controlled by clinopyroxene. In addition, the large grain sizes of garnet also raise the closure temperature (e. g., Dodson, 1973). Thus, if a high closure temperature of $850-900{ }^{\circ} \mathrm{C}$ for the $\mathrm{Sm}-\mathrm{Nd}$ system in garnet is applicable to our samples, the age of $244 \pm 11 \mathrm{Ma}$ is likely to represent the lower limit for the peak metamorphism in the NDC. If this postulation is correct, then the age of the peak metamorphism in the NDC is about 10-20 Ma higher than in the SDT. This suggests earlier cooling for the rocks in the NDC than in the SDT. A possible explanation is that the NDC was an overthrusted wedge overlying the subducted continental crust of the Yangtze craton (Li et al., 1996). Other ages being useful for tectonic reconstructions include the following: biotite and hornblende from the NDC yielded ${ }^{40} \mathrm{Ar} /{ }^{39} \mathrm{Ar}$ ages of 120-135 Ma (Chen et al., 1995;

Hacker and Wang, 1995); Rb-Sr, Sm-Nd and ${ }^{40} \mathrm{Ar} /{ }^{39} \mathrm{Ar}$ analyses on mineral fractions of coarse-grained gabbros also show Cretaceous ages ( 125 Ma; Jahn et al., 1999b). These ages are believed to reflect reheating by post-collisional magmatic/extensional events (Hacker et al., 1995; Li et al., 1998).

Based on observed textures, fluid inclusion data, oxygen isotope compositions, P-T estimates and metamorphic ages, retrograde P-T-t-fluid paths for the metamorphic rocks from the SDT and NDC are summarized in Fig. 9.1a and b, respectively.

\subsection{Fluid behavior during metamorphic evolution of the rocks in Dabie Shan}

\subsubsection{Meteoric water-rock interaction prior to metamorphism?}

Oxygen isotope compositions of minerals from the SDT cover a wide range: the $\delta^{18} \mathrm{O}$ value ranges from -4.6 to $7.8 \%$ o for garnet, from -1.0 to $9.7 \%$ o for quartz and from -2.4 to $7.8 \%$ o for clinopyroxene. When combined with previous oxygen isotope studies in Dabie Shan 


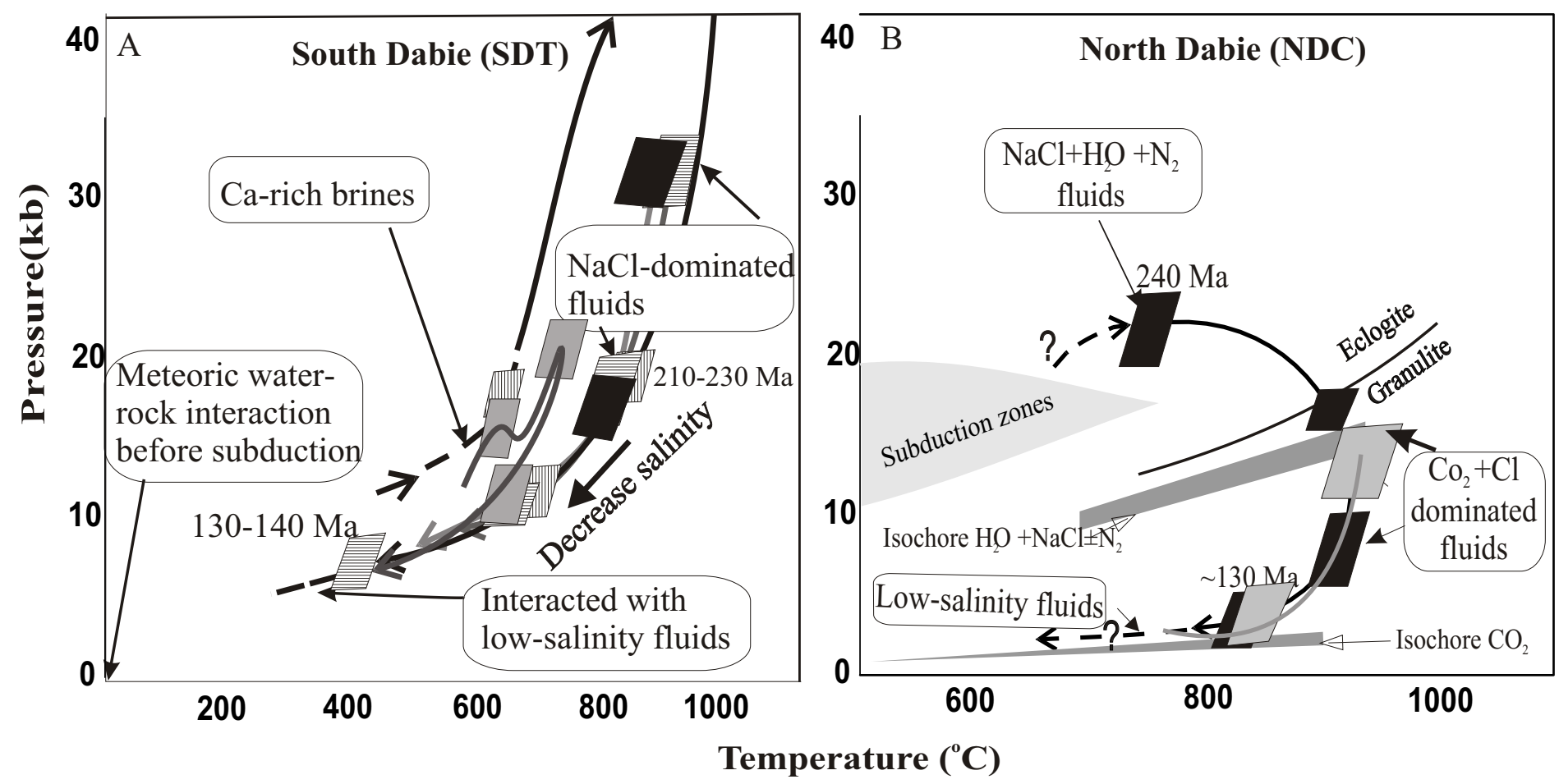

Fig. 9.1. P-T-t-fluid paths of the UHP metamorphic rocks from SDT(A) and HP metamorphic rocks from NDC (B). 
(e.g., Baker et al., 1997; Yui et al., 1997; Rumble and Yui, 1998; Zheng et al., 1998, 1999), we can conclude that there was a meteoric water-rock interaction(s) prior to subduction for metamorphic rocks from the SDT. Such a meteoric water-rock interaction(s), however, was very variable from locality to locality.

In contrast, the measured oxygen isotope data for the rocks from Raobazhai and Yanzihe in the NDC do not show any obvious indications of water-rock interaction before subduction. Touret (1989) stated that granulite formation can be distinguished in either fluidabsent metamorphism or carbonic metamorphism. In the first case oxygen isotope compositions would remain largely unchanged, whereas in the latter case changes in the isotopic compositions are expected. However, meta-igneous rocks of mafic or felsic compositions with $\delta^{18} \mathrm{O}$ of 6 to $10 \%$ will remain unchanged even during carbonic metasomation as $\delta^{18} \mathrm{O}$ values of mantle-derived $\mathrm{CO}_{2}$ are around $10 \%$ (Mattey et al., 1994). Although fluid inclusions of Raobazhai and Yanzihe suggest that the granulite-facies metamorphism in the NDC was $\mathrm{CO} 2$ dominant, the $\delta^{18} \mathrm{O}$ values from Raobazhai and Yanzihe are expected to be close to the oxygen isotope compositions of the respective protoliths, i.e., theoxygen isotope compositions do not indicate meteoric water-rock interaction.

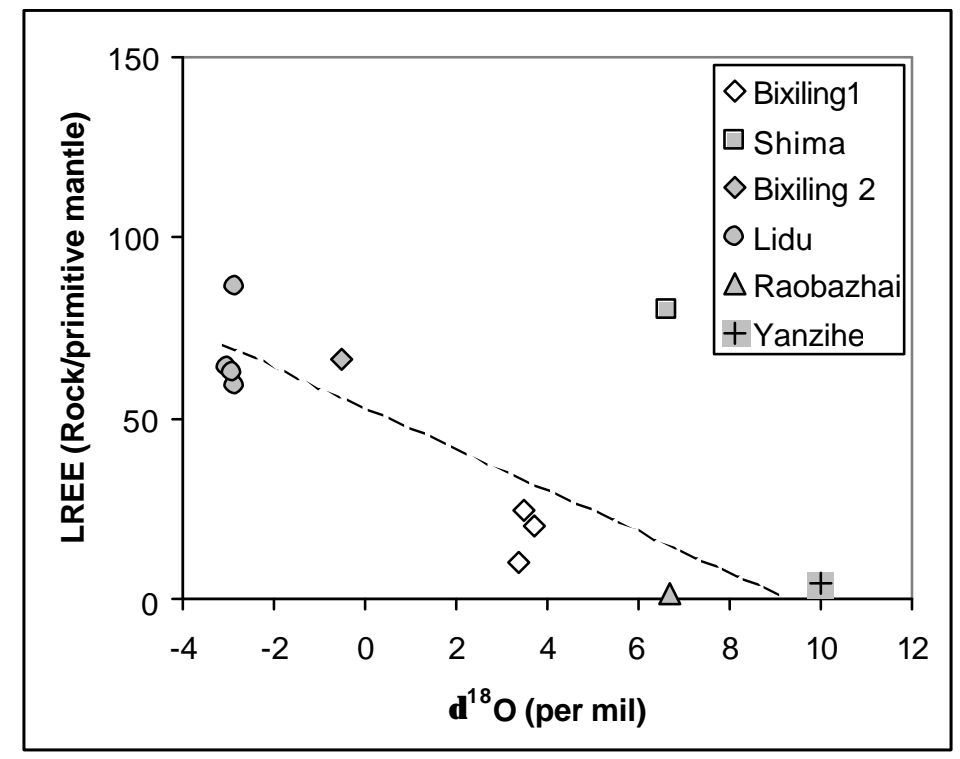

Fig. $\quad 9.2$ Plot of primitive mantle-normalized, measured whole-rock REE data vs $\delta^{18} \mathrm{O}$ values of metamorphic rocks from Dabie Shan. Bixiling 1, unaltered eclogites and ultramafic rocks in Bixiling; Bixiling 2, retrograded eclogite in Bixiling.

The conclusion that, metamorphic rocks in the SDT had a meteoric water-rock interaction before subduction but those in the NDC had not, is supported by the present REE data. As shown in Fig. 9.2, a negative correlation exists between $\delta^{18} \mathrm{O}$ values and LREE 
concentrations of whole rocks (the sample from Shuanghe has been excluded because it is a meta-sediment). Samples from Bixiling and Lidu, which have $\delta^{18} \mathrm{O}$ values of -2.8 to $3.7 \%$, showing obvious indications for meteoric water-rock interaction, have higher LREE concentrations than the other samples. Although the eclogite from Shima show normal $\delta^{18} \mathrm{O}$ values, the higher LREE content indicates an interaction with a REE-bearing fluid prior to UHP metamorphism (no obvious retrograde metamorphic indicator in the studied sample). By contrast, eclogite (Raobazhai) and granulite (Yanzihe) from the NDC have much lower LREE concentrations and "normal" $\delta^{18} \mathrm{O}$ values, which do not support a meteoric water-rock interaction before their metamorphism.

\subsubsection{Closed fluid system during peak metamorphism}

Garnet porphyroblasts from the Raobazhai eclogite and Yanzihe granulite in the NDC have more or less homogeneous $\delta^{18} \mathrm{O}$ values, which indicate closed system conditions during garnet growth. Any infiltrating fluids present during garnet growth should cause an oxygen isotope gradient from the center outwards to the rim, because the isotopic front that is moving through the rock becomes less steep with increasing distance from the contact (Chamberlain and Conrad, 1993). Therefore, no external fluids infiltrated the eclogite and granulite during garnet growth. In other words, fluid phases present in the rocks of NDC should be of internal origin during eclogite- and subsequent granulite-facies metamorphism. Furthermore, REE analyses of these garnet porphyroblasts show that the REE concentrations are slightly higher in the garnet cores than in the rims. This suggests the existence of a fractionation process, and hence supports the conclusion that there was no significant fluid-rock interaction during garnet growth.

According to Watson et al. (1990), fluids in the shallowest upper mantle - 10 to 20 kbar or 33 to $66 \mathrm{~km} \mathrm{-} \mathrm{are} \mathrm{CO}_{2}$-rich, and $\mathrm{H}_{2} \mathrm{O}$-poor. At pressures above the stability of amphibole (> 23kbar; Olafsson and Eggle r, 1983), the stable hydrous phase is phlogopite. Because of the low concentration of $\mathrm{K}_{2} \mathrm{O}$ in the upper mantle (hundreds of p.p.m) little phlogopite can be formed and much of the $\mathrm{H}_{2} \mathrm{O}$ is partitioned into the fluid phase. In this way the fluid-phase at depths $>80 \mathrm{~km}$ becomes water-rich and salinities may be reduced. The preservation of high-salinity fluid inclusions in eclogites from Bixiling and Shima indicates that the UHP eclogites in the SDT represent a relatively closed fluid system during peak metamorphism, and that fluid migration must have been limited, at depths below $80 \mathrm{~km}$. Philippot (1993) already has shown that fluid migration in eclogite is small at pressures $>10$ 
kbar. Thus, the limited fluid mobility and the possible "in situ" density reequilibration indicate that the composition of fluid inclusions in garnet, omphacite and kyanite are likely to represent the fluids during UHP metamorphism. Furthermore, the preservation of presubduction meteoric water signature and oxygen isotope equilibrium among minerals in the SDT also indicate limited oxygen isotope exchange between the subducted rocks and the surrounding mantle material, i.e., closed system conditions during UHP metamorphism.

Aranovish \& Newton (1997) have demonstrated that the presence of $\mathrm{NaCl}$ decreases significantly the water-activity $\left(a \mathrm{H}_{2} \mathrm{O}\right)$; thus high-salinity aqueous inclusions (brines) and $\mathrm{CO}_{2}$-dominated inclusions indicate low water activity during eclogite- and granulite facies metamorphism in both NDC and SDT. The low $a \mathrm{H}_{2} \mathrm{O}$, which is essential for the stability of the granulite-facies minerals, is explained by the lack of a free fluid phase (Touret \& Huizenga, 1999). This lends support to the proposal that the preservation of coesite as inclusions in other minerals indicates a lack of free-fluid during UHP metamorphism in the SDT which would otherwise catalyse retrogressive phase changes (Hacker and Peacock, 1995). This also means that, if any coesite (or other UHP index minerals) would be present during peak metamorphism of the rocks in the NDC, UHP index minerals also should occur as inclusions in other minerals because of the very low $a \mathrm{H}_{2} \mathrm{O}$. The fact that so far no UHP index minerals has been found in the NDC suggests the absence of UHP metamorphism in the NDC.

\subsubsection{Indicators of retrograde fluid/rock interaction}

As demonstrated in section 7.1, oxygen isotope equilibrium has been achieved in the investigated samples from the SDT. In the NDC, however, the negative fractionations of -1.7 to $-0.5 \%$ o between secondary amphibole and plagioclase and garnet in Raobazhai, and of $1.9 \%$ between Opx and amphibole and garnet in Yanzihe indicate isotope disequilibrium. This disequilibrium can be best interpreted as resulting from fluid/rock interactions during the retrograde formation of these minerals. Because different minerals have different closure temperatures for oxygen isotope exchange (garnet being the most resistant, whereas such minerals as amphibole and plagioclase are more susceptible), differential isotopic exchange has taken place between the minerals and retrograde fluids.

The postulation that metamorphic rocks in the NDC have been subjected to retrograde fluid-rock interactions is supported by unusually Clcontents in secondary amphiboles in the NDC, with $0.4 \%$ in Raobazhai and up to $4.0 \%$ in Yanzihe. Thus, it is reasonable to assume 
that there was a regionally extensive retrograde fluid-rock interaction, although further work is needed to support this assumption.

In the SDT, significantly lower $\delta^{18} \mathrm{O}$ values and lower salinities of the secondary fluid inclusions in matrix quartz of retrograded eclogite indicate a retrograde fluid-rock interaction at the margin of the Bixiling eclogite. These retrograde fluids must have been low-salinity aqueous or almost pure water and have $\delta^{18} \mathrm{O}<0 \%$, which point to infiltrated surface waters of meteoric origin or fluids derived from the surrounding gneisses with low- $\delta^{18} \mathrm{O}$. The so far reported maximum depth of meteoric-water penetration in the crust is about $12 \mathrm{~km}$ (e.g. Wickham and Taylor 1987); at this depth the generally observed temperature is lower than the oxygen isotope closure temperature of garnet. Therefore, we assume that the eclogite interacted with retrograde fluids derived from the surrounding gneiss at high temperatures. During late retrograde metamorphism, probably after the symplectite stage, fluids with lowsalinity and $\delta^{18} \mathrm{O}$ values $<0 \%$ were produced along the boundary zone between ecologite and wall rock gneiss due to a tectonic extension of this region in the early Cretaceous ( $\mathrm{Li}$ et al. 1993). At that time, metamorphic temperatures must have been relatively high (600$\left.700^{\circ} \mathrm{C}\right)$, and the cooling rate was 'slow' ( $7^{\circ} \mathrm{C} / \mathrm{Ma}$, Chavagnac and Jahn, 1996); therefore the oxygen isotope compositions of the minerals, including garnet, which is highly resistant to isotopic exchange, were reset during the retrograde water-rock interaction, and a late oxygen isotope re-equilibrium has been reached. This may be the reason that there are no signs of isotopic dis-equilibrium in the retrograde eclogite. However, since the eclogite body in Bixiling is too large $\left(1.5 \mathrm{~km}^{2}\right)$ to be completely reset, only the marginal portions of the body were reset.

The secondary $\mathrm{CO}_{2}$-rich inclusions in jadeite quartzite from Shuanghe may be related to retrograde fluids from coexisting marbles (see also $\mathrm{Fu}$ et al., 2000). It is unlikely that the $\mathrm{CO}_{2}$ component resulted from its metasedimentary protolith because no primary carbonic inclusions has been observed in the rock. Secondary almost pure water inclusions in the Lidu eclogite indicate the presence of a low-salinity fluid during retrograde metamorphism. The source of such low-salinity fluid, however, is unclear so far. UHP eclogites with retrograde fluid-rock interactions from other localities in the SDT also have been described by Yui et al. (1997) and Zheng et al. (1999), though Yui et al. (1997) suggested that the retrograde fluid was either derived from meteoric water infiltration or from low $\delta^{18} \mathrm{O}$ gneisses, whereas Zheng et al. (1999) considered that it could be derived from structural hydroxyls groups dissolved in nominally anhydrous minerals. 
The eclogite from Shima does not show any significant retrograde signatures, indicating a closed system throughout metamorphism. Baker et al. (1997) observed no oxygen isotope shifts during amphibolite-facies overprints of the UHP eclogites from Shima and other localities in the SDT and concluded that if an exotic fluid would be involved in the retrograde metamorphism, it should be either in or very close to isotopic equilibrium with the eclogite minerals.

In summary, it is concluded that there was retrograde fluid-rock interaction in the SDT. It was, however, limited and variable from locality to locality. This may be in contrast to the case of the NDC.

\subsubsection{Open system conditions in the Lidu eclogite}

The discovery of oxygen isotope zoning in garnets from Lidu (section 7.1.4) has important implications for the question whether the rocks have been affected by fluid infiltration during metamorphism. Oxygen isotope zoning can be caused by fluid infiltration but also can be affected by diffusion processes, temperature changes, and compositional variations during garnet growth. The diffusivity of oxygen in garnet is exceedingly low at metamorphic temperatures up to $700{ }^{\circ} \mathrm{C}$, thus diffusion is an unlikely process. Therefore, we focus our discussion to temperature change, compositional variation, and fluid infiltration.

It has been suggested that garnet growth be gins at about $400{ }^{\circ} \mathrm{C}$ (e.g., Christensen et al., 1989). Temperatures calculated from quartz-garnet $\delta^{18} \mathrm{O}$ data agree with temperatures calculated from cation thermometry (see section 8.4), indicating peak metamorphic temperatures around $700{ }^{\circ} \mathrm{C}$ for the Lidu eclogite. Thus, it is reasonable to assume that garnet from Lidu has been formed between 400 and $700{ }^{\circ} \mathrm{C}$. Zheng (1993a) revealed a relatively small oxygen isotope fractionation of $<0.2 \%$ between garnet and fluid at $400-700{ }^{\circ} \mathrm{C}$. The observed shifts in $\delta^{18} \mathrm{O}$ values, however, from the core to the central zone, and from the central zone to the rim of the garnet, are 0.5 to $0.6 \%$, a factor of 2 to 3 times higher than that could result from temperature variations. Thus, it is unlikely that a temperature change during garnet growth could result in such an oxygen isotope shift.

Cation substitution can affect the oxygen isotope compositions of minerals. Taylor and O'Neil (1977) suggested grossular is enriched in ${ }^{18} \mathrm{O}$ compared to andradite at $600{ }^{\circ} \mathrm{C}$, whereas a recent study from Kohn and Valley (1998) indicates that Ca-poor, Fe-rich garnet is enriched in ${ }^{18} \mathrm{O}$ compared to grossular at about $700{ }^{\circ} \mathrm{C}$. However, the effects on fractionation factors of the cation substitutions cannot explain the oxygen isotope zoning patterns in the 
garnet from Lidu. As shown in Fig. 4.7, the almandine content decreases from $\sim 62 \%$ in the core to $\sim 50 \%$ in the rim. Although grossular and pyrope contents vary in the central zone of the garnet, these variations are too small to explain the observed ${ }^{18} \mathrm{O}$ variations.

REE analyses of the same garnet indicate that REE concentrations in the rim are about 3 orders of magnitude higher than those in the core (Fig. 5.11). The REE zoning patterns can not result from crystal fractionation processes, which usually cause a REE decrease towards the garnet rim (e.g. garnets in Raobazhai and Yanzihe). Fluids with variable REE concentrations during garnet growth are the most probable cause for the observed REE pattern.

Therefore, infiltrations of fluids with different $\delta^{18} \mathrm{O}$ values into the Lidu eclogite during garnet growth are the most likely cause responsible for the observed $\delta^{18} \mathrm{O}$ zoning in garnet. Garnets in the eclogite from Huangzhen, another "cold" eclogite locality close to Lidu, have a relatively large range of $\delta^{18} \mathrm{O}$ values between -5.2 to $-0.1 \%$ o (Zheng et al., 1999), indicating locally heterogeneous fluid-rock interactions during metamorphism. Heterogeneous fluid-rock interactions during metamorphism are observed for all the other metamorphic rocks in the SDT (e.g., Baker et al., 1997; Yui et al., 1997; Zheng et al., 1998, 1999).

The oxygen isotope zoning in the garnet indicates that the eclogite from Lidu was open to external fluids during garnet-grade metamorphism, or even peak metamorphism. This is in accord with the fluid inclusion study, which shows that most fluid inclusions in the Lidu eclogite are almost pure water inclusions with healed fractures (see section 6.4), indicating high water-activity during metamorphism. Moreover, many hydrous phases such as tak, chlorite, mica and amphibole occur in the matrix and as inclusions in garnet suggesting fluid incorporation throughout metamorphism. However, such an open system behavior contrasts to most UHP eclogites, which are usually closed during UHP metamorphism. The "cold" eclogite from Lidu in the SDT therefore has a somewhat unusually different metamorphic evolution.

\subsection{Origin of nitrogen in metamorphic fluids of Dabie Shan}

$\mathrm{N}_{2}$-rich fluids have been described from eclogites of the Caledonides (e.g., Andersen et al., 1989, 1990, 1993), the Münchberg complex in Bavaria (Klemd, 1991; Klemd et al., 1993), and from eclogite nodules in kimberlites of Siberia (Tomilenko and Chupin, 1983). In contrast, in eclogites from the Alps and in many blueschists, fluid inclusions related to peak metamorphic conditions are dominated by more or less complex aqueous brines, without 
evidence of $\mathrm{N}_{2}$ (Selverstone et al., 1984; Philippot and Selverstone, 1991; Philippot, 1993; Touret, 1992). Such a difference in fluid regimes is suggested to be a consequence of different tectonic environments during eclogite formation (Andersen et al., 1993; Klemd and Bröcker, 1999). Along an oceanic subduction zone, large volumes of clastic sediments are subducted together with hydrated oceanic crust, representing a considerable reservoir of highly nitrogenfertile material; thus eclogites formed from oceanic crust will be relatively $\mathrm{N}_{2}$-enriched. On the other hand, if an aqueous fluid is generated by dehydration reactions, and unable to escape within the downgoing slab (e.g., continent-continent collision), the water activity would remain high until dehydration has reached an advanced stage; eclogites formed under such tectonic settings would keep most nitrogen in solid mineral phases (Andersen et al., 1993).

In the case of Dabie Shan, fluid inclusions in most eclogites and other metamorphic rocks are dominated by Nㅡ-free solutions or gases (e.g. You et al., 1996; Xiao et al., 2000; the present study), indicating these rocks are related to continent-continent collision tectonics. However, rare $\mathrm{N}_{2}$-rich inclusions have also been described for the eclogites from Shuanghe (Fu et al., 2000) and Raobazhai (Xiao et al., 2001). Recent studies have demonstrated that the Raobazhai complex is probably of mantle origin (Zhang Q. et al., 1995; Zhang R. et al., 1996). Although the investigated whole-rock shows a MORB-like REE pattern, the negative $\varepsilon \mathrm{Nd}(\mathrm{t})$ values (around -3 ) indicate that it cannot represent subducted oceanic crust. Li et al. (2000) suggested that the protoliths of the eclogites in Shuanghe are volcanic rocks. Thus, possible sources for nitrogen in the eclogites in Dabie Shan include the mantle and nitrogenrich crustal rocks, such as metasediments subducted to great depth.

Previous studies on the composition of fluid inclusions in mantle-derived rocks have shown that carbon dioxide is an ubiquitous component in mantle xenoliths (e.g., Roedder, 1965, 1984; Murk et al., 1978; Andersen et al., 1984; Pasteris, 1987;), but nitrogen is not. However, nitrogen has been found in diamonds, and in minor amounts in phlogopite and amphibole where it may substitute for potassium. The average nitrogen content of the mantle is <2 ppm (Norris and Schaeffer 1982), which is much lower than that in crustal rocks (c. 20 ppm, Wlotzka, 1961).

Metasedimentary rocks are one of the major lithological units of the NDT (Liou et al., 1995). Abundant UHP paragneiss, marble and jadeite quartzite occur also in Shuanghe (Cong et al., 1995). There is now abundant evidence that both eclogites and their country rocks in the SDT experienced the same Triassic UHP metamorphic history (e.g., Wang and Liou, 1991; Rowley et al, 1997; Hacker et al., 1998; Rumble and Yui, 1998). Therefore, nitrogen released from such metasediments at great depths may be a likely source for the $\mathrm{N}$ present in 
the eclogite-facies fluids. In Raobazhai, as the $\mathrm{N}_{2}$-bearing fluid inclusions were trapped during the peak metamorphism, the $\mathrm{N}_{2}$-enriched metamorphic fluids should be formed during or before the peak metamorphism.

\subsection{Cl-bearing amphiboles in the NDC}

Recent studies (Kullerud 1995, 1996; Markl et al., 1998; Kullerud and Erambert, 1999) have demonstrated that fluid composition is the most important factor controlling the Cl-contents of amphibole and biotite, whereas crystal chemical constraints related to the cation composition of amphibole (e.g. the $\mathrm{Fe} / \mathrm{Mg}$ ratio) are of much less importance. Because $\mathrm{Cl}$ has a pronounced preference for hydrous fluid relative to silicates and only enters solid phases in significant amounts if the chlorinity of the fluid is high and/or if the water activity is very low (Volfinger et al., 1985; Zhu and Sverjensky, 1991), even low amounts of $\mathrm{Cl}$ in amphibole point to the existence of Cl-rich solutions. Hence, the high $\mathrm{Cl}$ content in amphiboles from the investigated samples, both in Raobazhai and Yanzihe, points to the existence of a very Clrich fluid during the metamorphism of the NDC.

Kullerud (1995, 1996) and Markl and Bucher (1998) suggested similar "desiccation mechanism" for the formation of Cl-bearing minerals in granulites from the Lofoten, Norway. According to Kullerud's $(1995,1996)$ model, the influx of the externally derived fluid phase ceased shortly after an initial grain-boundary saturation; later, the grain-boundary fluid was consumed during amphibole and/or biotite- forming reactions. As $\mathrm{Cl}$ has high fluid/solid partition coefficients, the first hydrous minerals that formed during the fluid-rock interactions were Cl-poor; continued hydration reactions resulted in a successive increase in the $\mathrm{Cl}$ content and the activity ratio $\mathrm{a}_{\mathrm{Cl}}-\mathrm{a}_{\mathrm{OH}^{-}}$of the fluid phase; thus, low-Cl amphibole formed at an early stage, whereas the most $\mathrm{Cl}$-enriched amphibole formed in equilibrium with salt and the "last droplets" of a highly saline grain-boundary fluid.

However, as shown in Fig. 4.15, Clenriched amphiboles in Yanzihe should form earlier than the Cl-poor amphiboles, which disagrees with the "desiccation" model. Furthermore, the "desiccation" model cannot explain the formation of Cl-rich amphibole veins in garnet. These veins are most likely formed during retrograde metamorphism and caused the lowering of $\delta^{18} \mathrm{O}$ values in garnet along the amphibole veins (see Fig. 7.6). Thus, it seems that the "desiccation" model may not be applicable for the Cl-enriched amphiboles in the NDC. To constrain the origin(s) of such amphiboles in the NDC, further investigations 
are needed. Nevertheless, the higher Clontent in the amphiboles from the NDC contrasts to those in the SDT, indicating their different fluid histories.

Primary fluid inclusions indicate that the major component of the fluid phase during the granulite-facies metamorphism in the $\mathrm{NDC}$ is $\mathrm{CO}_{2}$. The presence of Cl-rich amphiboles indicates that $\mathrm{Cl}$ was also a major component in the fluid phase. Chlorine isotope data from granulites have suggested that the common occurrence of Cl-enriched minerals in granulite facies terrains is a product of remobilized crustal Cl (Markl et al., 1997). Therefore, fluid compositions of the rocks from the NDC may indicate their lower-crustal origin. This is consistent with $\mathrm{Pb}$ isotopes, which suggest that the protoliths of the metamorphic rocks in the NDC are of lower crust origin, whereas those of the SDT are of upper crust origin (Li S. G., personal communications). 


\section{Chapter 10. TECTONIC IMPLICATIONS}

\subsection{Nature of protoliths}

Major and trace elements, and REE characteristics presented above indicate that the protoliths of the studied rocks derived from heterogeneous sources, which are further influenced by fractional crystallization. Overall, the present whole-rock data indicate that the protoliths of the studied rocks, mainly from the SDT, formed probably in an island-arc tectonic environment. In a more extensive study of the UHP eclogites in Dabie Shan, You et al. (1996) reached the same conclusion. In an additional study for the gneisses in Shima, Xiao (1991) concluded that the protoliths of the gneisses in the SDT were also of island-arc origin. Furthermore, the generally low $\varepsilon_{\mathrm{Nd}}(220 \mathrm{Ma})$ values (-6 to -20$)(\mathrm{Jahn}, 1998)$ and U-Pb zircon upper intercept ages (Ames et al., 1993) indicate that most eclogite protoliths are of Proterozoic age. The presence of these UHP eclogites implies deep subduction of a continental block.

On the other hand, various tectonic settings have been suggested for the NDC: (1) a metamorphosed ophiolite mélange complex in the suture (Xu et al., 1992, 1994), (2) a thrust plane in the subducted continental basement of the Yangtze craton (Okay and Sengör, 1993; Maruyama et al., 1994), (3) an island arc near the North China craton (Zhai et al., 1994), (4) part of the North China craton in the hanging wall of the subduction zone (Liou et al., 1996; Zhang et al., 1996), (5) a microcontinent between the Yangtze and North China cratons (Li et al., 1998) or, (6) a Creataceous magmatic complex formed in the post-collision extension (Hacker et al., 1998).

As described above, the NDC consists of a "basement" assemblage of orthogneiss, migmatite, granulite, marble and ultramafic rocks, and an intrusive suite of Cretaceous granites and minor mafic-ultramafic intrusions. Among them, orthogneiss is the major component of the NDC; its protolith has been suggested to be a suite of TTG (trondhjemitictonalitic-granodioritic) rocks that represent a former magmatic arc association (Cong et al., 1994). Initial U-Pb zircon dating suggests that the granulites in the NDC were fragments of an ancient lower crust (Chen et al., 1996). Based on a detailed study of the metamorphic rocks in the NDC, Zhang et al. (1996) suggested that orthogneisses from the NDC differ in their mineral assemblage from gneisses in the SDT, and that the rock association in the NDC has distinct affiliations with an active continental margin. 
Nd model ages ( $\left.\mathrm{T}_{\mathrm{DM}}\right)$ of the rocks from the NDC and the SDT suggest that they are from two independent tectonic units. The orthogneisses samples from the NDC gave $T_{D M}$ values ranging from 2.0-2.6 Ga; by contrast, orthogneisses collected from a broad area in the SDT yielded $\mathrm{T}_{\mathrm{DM}}$ values of 1.5 to $1.8 \mathrm{Ga}$, while UHP paragneisses have $\mathrm{T}_{\mathrm{DM}}$ values of 2.4 to $2.9 \mathrm{Ga}$ ( $\mathrm{Li}$ et al., 1998). Xie et al. (1996) argued that the upper layer of the SDT is mainly composed of the orthogneiss with younger $\mathrm{Nd}$ model ages and foreign UHP metamorphosed slabs, and the lower layer represents an old basement of the Yangtze craton. In contrast, the NDC is an uniform old metamorphic terrain (Li et al., 1998).

Field data have suggested limited distributions for syncollisional mafic-ultramafic intrusions in the NDC. This feature indicates that the NDC is likely to be an overlying crust wedge above the subduction zone rather than a subducted continental crust (Li et al., 1998).

\subsection{Tectonic interpretation}

Different tectonic models have been proposed for the formation of the Dabie UHP terrain. All models agreed in that (1) the Yangtze and North China cratons are the principal continental colliders, and the Dabie - Sulu terrain is the collision orogen between two cratons, (2) the Yangtze craton subducted northward beneath the North China craton during the Triassic. However, the exact location of the suture is still under debate. Zhang et al. (1996) have proposed that the suture is located in the central Dabie Shan between the SDT and NDC. Chen and Jahn (1998) suggested that the suture is more likely located in the northern margin or to the north of the Dabie orogen. Based on the distribution of eclogites, and metamorphic ages, Hacker et al. (1998) considered that the position of the suture should be located on either the northern or southern contact of the Nanwan Formation, rather than along the Xiaotian-Mozitang Fault near the northern edge of the Dabie Shan (Hacker et al., 1995).

The contrasting fluid histories, P-T evolutions, and other geochemical characteristics for the SDT and NDC indicate that heir boundary probably represents the suture between the North China and Yangtze cratons. This lends support to the suggestion that the NDC may represent the North China hanging wall during the Triassic subduction for the formation of the ultrahigh- and high-pressure units to the south (Zhang et al., 1996; Liou et al., 1996).

Figure 10.1 illustrates a conjectural plate-tectonic scenario for the tectonic evolution between the North China and Yangtze cratons that is responsible for the formation of the metamorphic rocks in the SDT and NDC. During the late Permian or early Triassic, the Yangtze craton collided with the North China craton (Fig. 10.1A). This collision event caused 
a deep continental subduction of the Yangtze craton under the North China craton. At that time the SDT was the northern edge of the subducted Yangtze craton, whereas the NDC was part of an overthrust wedge of middle to low continental crust. Depending on depth, assemblages of the UHP, amphibolite, blueschist/greenschist zones developed on the subducted Yangtze craton. Furthermore, rocks in the northern margin (e.g. Bixiling) may have been subducted to much greater depth than those in the southern margin of the SDT (e.g. Lidu). The different protoliths and tectonic environments caused the compositional differences of the fluid phases in the SDT and NDC. Small amounts of fluid in the SDT were mainly high-salinity solutions, while those in the NDC was dominated by $\mathrm{CO}_{2}$ and $\mathrm{Cl}$. On the other hand, subduction of old and cold supracrustal rocks may not have produced sufficient fluid, which has resulted in the widespread preservation of the UHP metamorphic assemblage and the limited amount of syn-collsional granite in the hangingwall (Liou et al., 1996). The limited amounts of fluids, however, might promote small-scale partial melting in the overthrust plate.

The contrasting retrograde P-T paths of the SDT and NDC indicate they have different exhumation histories. Subduction of a continental lithosphere must stop at great depths (e.g. $>120 \mathrm{~km}$ ?) because of its lower density compared to the asthenosphere. However, the denser oceanic lithosphere continued to subduct and sometimes detached from the continental lithosphere (e.g., Davis and von Blanckenburg, 1995). Such a "slab breakoff" process would cause the subducted continental lithosphere to rebound or uplift rapidly to much shallower depths (Fig. 1B, see also Jahn et al., 1999). By contrast, high-T rocks of the hangingwall exhumed much slower from intermediate to lower crustal depth showing a compression path with substantial heating.

In the early Cretaceous, due to decoupling of the thermal boundary layer in the subducted lithosphere (Anderson et al., 1991), the tectonic setting in the Dabie Shan area became to be extensional (see also $\mathrm{Li}$ et al., 1993). Many extensional volcanic basins and alkaline granites developed along the north side of the NDC in the early Cretaceous support this conclusion ( BGMR, 1987). Such an extensional environment would favor retrograde fluid-rock interactions.

In summary, such a tectonic model offers a reasonable explanation for the different fluid histories and P-T paths, as well as other geochemical characteristics between the SDT and NDC. It may further contribute evidence to the constraint of the location of the collision suture between the North China and Yangtze cratons. 


\section{A (>240 Ma)}

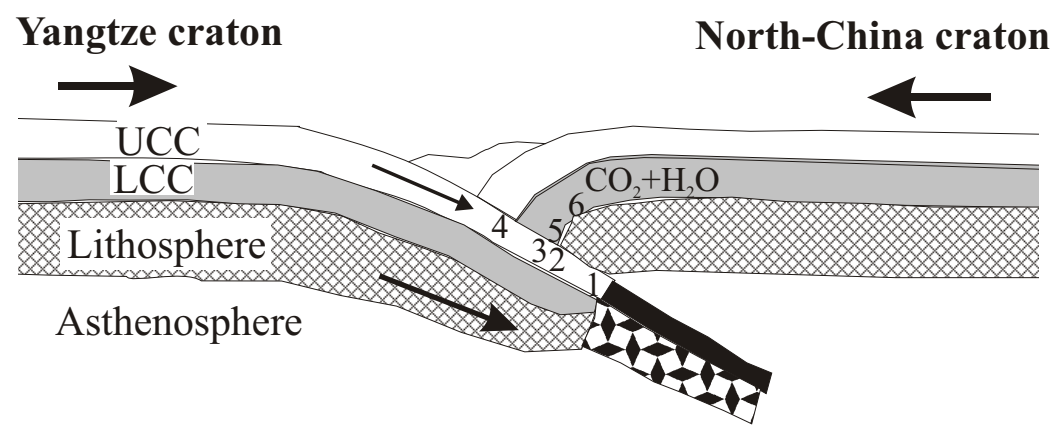

\section{B (210-230 MA)}

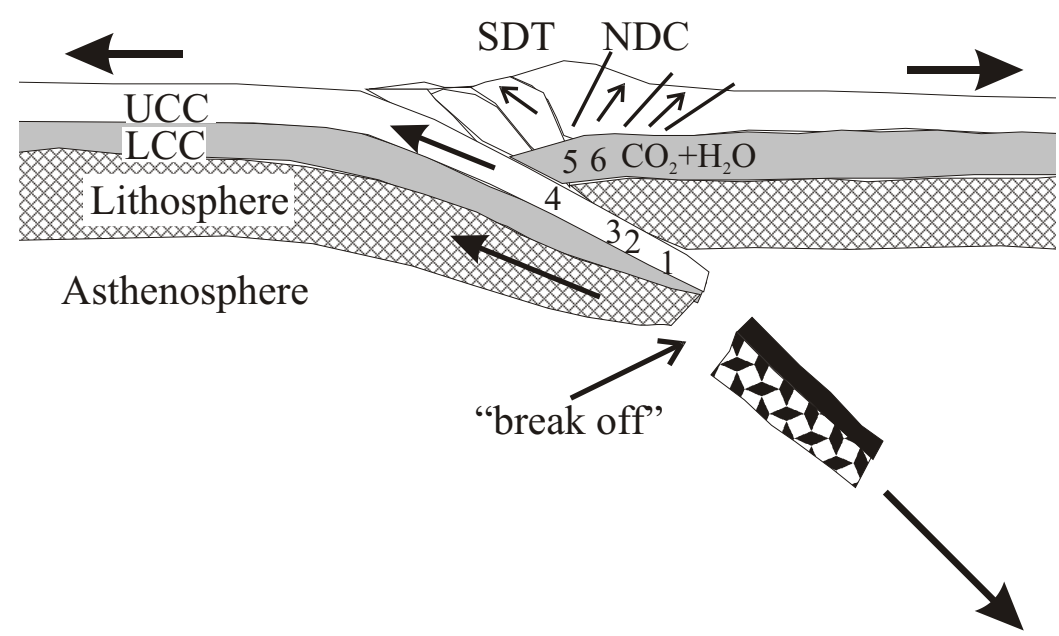

\section{C (present)}

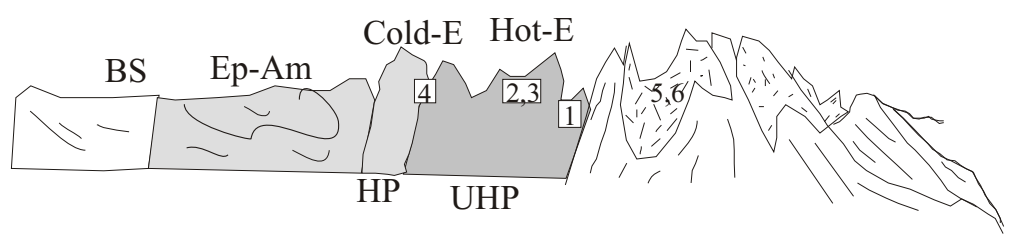

Fig. 10.1. Tectonic model showing the development of the investigated rocks. (A) after the continent-continent collision $(>240 \mathrm{Ma})$, the northward subduction of the Yangtze craton continued; due to the different positions in the subducted slab, the investigated rocks subjected to different metamorphic conditions. (B) the "detachment" of the eclogitized oceanic lithosphere caused the subducted continental lithosphere to rebound or uplift rapidly to shallower depths; on the other hand, metamorphic rocks on the overthrust plate, like Raobazhai ans Yanzihe, would uplift much slower. (C) present spatial distributions of the metamorphic rocks in the Dabie Shan (after Hacher et al., 1995). 1, Bixiling; 2, Shima; 3, Shuanghe; 4, Lidu; 5, Raobazhai; 6,Yanzihe; UCC,upper contintal crust;LCC, lower continental crust.BS, blueschist belt; Ep-Am, epidote-amphibolite belt Cold-E, cold eclogite; Hot-E, hot eclogite. 


\section{Chapter 11. CONCLUDING REMARKS}

(1) The fluid history of metamorphic rocks from the SDT is different from that of the NDC. The fluid system of the UHP metamorphic rocks in the SDT evolved from highly concentrated Ca-rich brines (prograde metamorphism) towards $\mathrm{NaCl}$-dominated solutions (peak metamorphism) and low salinity aqueous fluids during retrograde metamorphism. Although minor amounts of $\mathrm{CO}_{2}$ have been found in these fluids, $\mathrm{CO}_{2}$ appears to be not important during the metamorphic evolution of the rocks from the SDT. By contrast, the fluid phase of the rocks from the NDC was dominated by $\mathrm{CO}_{2}$-rich fluids, corresponding to granulite-facies.

(2) Metamorphic rocks in the Dabie Shan area display a large range of $\delta^{18} \mathrm{O}$ values, which probably resulted from variations of their protoliths and from heterogeneous fluid-rock interactions. The protoliths of the metamorphic rocks from the SDT have interacted with meteoric water on a regional scale prior to subduction, whereas the oxygen isotope compositions of the metamorphic rocks from the NDC show no obvious indications of such a water-rock interaction.

(3) Oxygen isotope mapping of garnet and fluid inclusion data indicate that the fluid phases in the rocks from both SDT and NDC, except for the "cold" eclogite from Lidu, were more or less closed during their peak metamorphism. Garnet from Lidu shows a systematic oxygen isotope zoning, which can be related to fluid infiltration during garnet growth, indicating that the eclogite was open to fluids during its peak metamorphism. From this point of view, the "cold" eclogite may have had a very different fluid evolution compared to the UHP eclogites in the SDT.

(4) Oxygen and hydrogen isotopes and fluid inclusion data imply that there were various retrograde fluid-rock interactions in both the SDT and the NDC, which was, however, limited and heterogeneous in the SDT, and perhaps regional in the NDC.

(5) Although previous studies have shown that $\mathrm{N}_{2}$-enriched solutions are typical peak metamorphic fluids in many eclogite localities worldwide, the present data indicate that nitrogen is not a major fluid component in the rocks from Dabie Shan. This could be due to their continent-continent collision setting.

(6) High contents of $\mathrm{Cl}$ in amphiboles from the NDC indicate that $\mathrm{Cl}$ was present once in very high concentration in the metamorphic fluids. In contrast, no $\mathrm{Cl}$ has been found in the minerals from the SDT, although $\mathrm{Cl}$ must have been an important component of the fluid phase too. 
(7) All investigated samples, except for the Lidu eclogite, have very low water activity during their peak metamorphism. This indicates that, if UHP index minerals would have been formed during peak metamorphism of the NDC, they should have been occasionally preserved like in the rocks from the SDT. Thus, most rocks in the NDC probably have not been subjected to UHP metamorphism.

(8) Pressure and temperature calculations suggest different P-T paths for the rocks from the SDT and NDC: rocks in the SDT have metamorphic peak temperatures that are synchronous with the maximum pressure along a nearly isothermal decompression path during early uplift, whereas those from the NDC show the maximum pressure that is followed by a decompression path with substantial heating. On the other hand, the consistent trend that the rocks in the northern margin have been subjected to much higher P-T conditions than those in the south margin may indicate the subduction direction of the Yangtze craton. 


\section{REFERENCES}

Ames L, Tilton GR and Zhou G (1993) Timing of collision of the Sino-Korean and Yangtze cratons: U-Pb zircon dating of coesite-bearing eclogites. Geology 21:339-342.

Ames L, Zhou G and Xiong B (1996) Geochronology and geochemistry of ultrahigh-pressure metamorphism with implications for collision of the Sino-Korean and Yangtze cratons, central China. Tectonics 15:472-489.

Andersen T, Austrheim H and Burke E (1990) Fluid inclusions in granulite and eclogites from the Bergen Arcs. Caledonides of W Norway. Mineral Mag 54:145-158.

Andersen T, Austrheim H, Burke E and Elvevold S (1993) $\mathrm{N}_{2}$ and $\mathrm{CO}_{2}$ in deep crustal fluids: evidence from the Caledonides of Norway. Chem Geol, 108:113-132.

Andersen T, Burke E and Austrheim H (1989) Nitrogen-bearing, aqueous fluid inclusions in some eclogites from the Western Gneiss Region of the Norwegian Caledonides. Contrib Mineral Petrol 103:153-165.

Andersen T, O'Reilly SY and Griffin WL (1984) The trapped fluid phase in upper mantle xenoliths from Victoria, Australia: implications for mantle metasomatism. Contrib Mineral Petrol, 88:72-85.

Anderson TB, Jamtveit B, Dewey JF and Swensson E (1991) Subduction and eduction of continental crust: major mechanisms during continent-continent collision and orogenic extensional collapse, a model based on the south Norwegian Caledonides. Terra Nova, 3:303-310.

Aranovich LY and Pattison DRM (1995) Reassessment of the garnet-clinopyroxene Fe-Mg exchange thermometer: I. Evaluation of the Pattison and Newton (1989) experiments. Contrib Mineral Petrol 119:16-29.

Armstrong JT (1991) Quantitative elemental analysis of individual microparticales with electron beam instruments. In: Heinrich KFJ and Newbury DE (eds) Electron Probe Quantitation. Plenum Press, New York, pp 261-285.

Baker J, Matthews A, Mattey D., Rowley D and Xue F (1997) Fluid-rock interactions during ultra-high pressure metamorphism, Dabie Shan, China. Geochim Cosmochim Acta 61:1685-1696.

Baker J, Matthews A, Mattey D., Xue F and Rowley D (1994). Fluid infiltration during ultrahigh pressure metamorphism, Dabie Shan, China. In: First workshop on UHP metamorphism and tectonics (ed. Liou JG), p75. 
Becker H, Jochum KP and Carlson RW (2000) Trace element fractionation during dehydration of eclogites from high-pressure terranes and the implications for element fluxes in subduction zones. Chem Geol, 163:65-99.

BGMR (Bureau of Geology and Mineral Resources of Henan Province) (1987) Regional Geology of Henan Province. Geol Pub House, Beijing.

Blundy JD and Holland TJB (1990) Calcic amphibole equilibria and a new amphibole plagioclase geothermometer. Contrib Mineral Petrol, 104:208-224.

Bohlen SR and Boettcher AL (1982) The quartz-coesite transformation: a pressure determination and the effects of other components. J Geophy Res, 87:7073-7078.

Bohlen SR, Valley JW and Essene EJ (1985) Metamorphism in the Adirondacks I: petrology, pressure, and temperature. J Petrol, 26:971-992.

Brown PE and Lamb WM (1989) P-V-T properties of fluid in the system $\mathrm{H}_{2} \mathrm{O} \pm \mathrm{CO}_{2} \pm \mathrm{NaCl}$ : New graphical presentations and implications for fluid inclusion studies. Geochim Cosmochim Acta 53:1209-1221.

Caby R (1994) Precambrian coesite from northern Mali: First record and implications for plate tectonics in the trans-Sahara segment of the Pan-African belt. Eur $\mathbf{J}$ Minreal 6:235-244.

Carswell DA (1975) Primary and secondary phlogopites and clinopyroxenes in garnet lherzolite xenoliths. Physics Chem Earth, 9:417-429.

Carswell DA, Wilson RH, Cong B, Zhai M and Zhao Z (1993) Areal extent of the ultrahighpressure metamorphism of eclogite and gneisses in Dabieshan, central China. Terra, 5:5.

Castelli D, Rolfo F, Compagnoni R and Xu S (1998). Metamorphic veins with kyanite, zoisite and quartz in the Zhu-Jia-Chong eclogite, Dabie Shan, China. The Island Arc, 7:159-173.

Chamberlain CP and Conrad ME (1993) Oxygen-isotope zoning in garnet: A record of volatile transport. Geochim Cosmochim Acta, 57:2613-2629.

Chavagnac V and Jahn B-M (1996) Coesite-bearing eclogites from the Bixiling Complex, Dabie Mountains, China: Sm-Nd ages, geochemical characteristics and tectonic implications. Chem Geol 133:29-51.

Chen JF, Dong SW, Deng Y and Chen Y (1993) Interpretation of K-Ar ages of the Dabie orogen - A differential uplifted block. Geol Review, 39:15-22.

Chen JF and Jahn BM (1998) Crustal evolution of southeastern China: Nd and Sr isotopic evidence. Tectonophysics, 284:101-133. 
Chen JF, Xie Z, Liu S, Li X and Faland KA (1995) Cooling age of Dabie orogen, China, determined by ${ }^{40} \mathrm{Ar} /{ }^{39} \mathrm{Ar}$ and fission track techniques. Sci China (B), 38:749-757.

Chen NS, You ZD, Suo ST, Yang Y and Li H (1996). U-Pb zircon ages of intermediateacidic granulite and deformed granite in the Dabie Mountains. Chinese Sci Bull, 41:1009-1012 (in Chinese).

Chopin C (1984) Coesite and pure pyrope in high-grade blueschists of the Western Alps: A first record and some consequences. Contrib Mineral Petrol 86:107-118.

Chopin C and Sobolev N (1995) Principal mineralogic indicators of UHP in crustal rocks. In: Coleman RG, Wang X (eds) Ultrahigh Pressure Metamorphism. Cambridge University Press, Cambridge, pp. 96-132.

Cohen AS, O'Nions RK, Siegenthaler R and Griffin WL (1988) Chronology of the pressuretemperature history recorded by a granulite terrane. Contrib Mineral and Petrol, 98: 303-311.

Coleman RG, Wang X (1995) Overview of the geology and tectonics of UHPM. In: Coleman and Wang X (eds), Ultrahigh-pressure metamorphism. Cambridge University Press, Cambridge. pp 1-23.

Cong BL, Wang QC, Zhai MG, Zhang RY, Zhao ZY and Ye K (1994) Ultrahigh pressure metamorphic rocks in the Dabie-Sulu region, China: their formation and exhumation. The Island Arc, 3:135-150.

Cong BL, Zhai MG, Carswell DA, Wilson RN, Wang QC, Zhao ZY and Windley BF (1995) Petrogenesis of ultrahigh-pressure rocks and their country rocks at Shuanghe in Dabieshan, Central China. Euro J Mineral, 7:119-138.

Cox KG, Gurney JJ and Harte B (1973) Xenoliths from the Matsoku Pipe. In: Nixson PH (ed), Lesotho Kimberlites. Cape and Transvaal Printers, Cape Town, pp76-91.

Davis JH and von Blanckenburg F (1995) Slab breakoff: a model of lithosphere detachment and its test in the magmatism and deformation of collisional orogens. Earth Planet Sci Lett, 129:85-102.

Deer WA, Howie RA and Zussman J (1992) An Introduction to the Rock-forming Minerals (Second edition). Addison Wesley Longman Limited, Harlow.

Dick LA and Robinson GW (1979) Chlorine-bearing potassium hastingsite from a sphalerite skarn in southern Yukon. Canadian Mineralogist, 17:25-26.

Dodson MH (1973) Closure temperature in cooling geochronological and petrological systems. Contrib Mineral Petrol, 40:259-274. 
Eide EA, Mcwilliams MQ and Liou JG (1994) ${ }^{40} \mathrm{Ar} /{ }^{39} \mathrm{Ar}$ geochronology and exhumation of high- pressure to ultrahigh pressure metamorphic rocks in eastern-central China. Geology, 22:601-604.

Eiler, J. M., Baumgartner, L. P. \& Valley, J. W., 1992. Intercrystalline stable isotope diffusion: A fast grain boundary model. Contributions to Mineralogy and Petrology, $112,543-557$.

Ellis DJ and Green DH (1979) An experimental study of the effect of Ca upon garnetclinopyroxene Fe-Mg exchange equilibria. Contrib Mineral Petrol 71:13-22.

Elsenheimer D and Valley JW (1992) In situ oxygen analysis of feldspar and quartz by Nd:YAG laser microprobe. Chem Geol, 101:21-42.

Fiebig J, Wiechert U, Rumble D, Hoefs J (1999) High-precision in situ oxygen isotope analysis of quartz using an ArF laser. Geochim Cosmochim Acta 63:687-702.

Franz L, Romer R, Klemd R, Schmid R, Oberhänsli R, Wagner T and Dong SW (2000) Eclogite-facies quartz veins within metabasites of the Dabie Shan (eastern China): P-T$\mathrm{t}-\mathrm{d}-\mathrm{x}$ conditions and fluid flow during exhumation of high-pressure rocks (submitted to Contrib Mineral Petrol).

Fu B, Xiao YL, Zheng YF, Touret JLR, Kerkhof van den AM and Hoefs J (2000) Fluid inclusions in ultrahigh-pressure metamorphic rocks from Shuanghe and Bixiling in Dabie Shan. Acta Petrol Sinica, 16:119-126 (in Chinese).

Fu B, Zheng YF, Wang ZR, Xiao YL, Gong B and Li SG (1999) Oxygen and hydrogen isotope geochemistry of gneisses associated with ultrahigh pressure eclogites at Shuanghe in the Dabie Mountains. Contrib Mineral Petrol, 134:52-66.

Gao S, Zhang BR, Gu XM, Xie Q, Gao CL (1995). Silurian-Devonian provenance changes of South Qinling basins: Implications for accretion of the Yangtze (South China) to the North China cratons. Tectonophysics, 250:183-197.

Christensen JM, Rosenfeld JL and DePaolo DJ (1989) Rates of tectonometamorphic processes from rubium and strontium isotopes in garnet. Science, 244:1465-1469.

Graham CM (1981) Experimental hydrogen isotope studies. III. Diffusion of hydrogen in hydrous minerals and stable isotope exchange in metamorphic rocks. Contrib Mineral Petrol, 76:216-228.

Graham CM and Powell R (1984) A garnet-hornblende geothermometer; calibration, testing, and application to the Pelona Schist, Southern California. J Metamorph Geol, 2:13-31.

Green II HW, Dobrzhinetskaya L, Riggs EM, Jin ZM (1997) Alpe Arami: a peridotite massif from the mantle transition zone? Tectonophysics, 279:1-21. 
Green DH and Ringwood AE (1967) An experimental investigation of the gabbro to eclogite transformation and its petrological applications. Geochimi Cosmochim Acta. 31:767833.

Gulyaeva TN, Gorelikova NV and Karabstov AA (1986) High-potassium-chlorine-bearing hastingsites in skarns from Primoye, far east USSR. Mineral Mag, 50:723-728.

Hacker BR and Peacock SM (1995) Creation, preservation, and exhumation of UHPM rocks. In: Ultrahigh Pressure Metamorphism, Coleman RG and Wang X (eds), Cambridge University Press, Cambridge, pp 159-181.

Hacker BR, Ratschbacher L, Webb L and Dong SW (1995) What brought them up? Exhumation of the Dabie Shan ultrahigh-pressure rocks. Geology, 23:743-746.

Hacker BR, Ratschbacher L, Webb L, Ireland T, Walker D and Dong SW (1998). U/Pb zircon ages constrain the architecture of the ultrahigh-pressure Qinling-Dabie Orogen, China. Earth and Planetary Science Letters, 161, 215-230.

Hacker BR and Wang QC (1995) Ar/Ar geochronology of ultra-high-pressure metamorphism in central China. Tectonics, 14:994-1006.

Hacker BR, Wang XM, Eide EA and Ratschbacher L (1996) The Qinling-Dabie ultrahighpressure collisional orogen. In: Yin A, Harrison TM (eds), The tectonic evolution of Asia. Cambridge Univ Press, UK, pp 345-370.

Harley SL (1984) The solubility of alumina in orthopyroxene coexisting with garnet in FeO$\mathrm{MgO}-\mathrm{Al}_{2} \mathrm{O}_{3}-\mathrm{SiO}_{2}$. J Petrol, 25:665-696.

Harlow GE, Veblen DR (1991) Potassium in clinopyroxene inclusions in diamonds. Science 251:652-655

Hartmann G (1994). Late-medieval glass manufacture in the Eichsfeld Region (Thuringia, Germany). Chemie der Erde, 54:103-128.

Hoefs (1997) Stable Isotope Geochemistry. 4th edition, Springer-Verlag Berlin Heideberg

Holland TJB (1979) High water activities in the generation of high-pressure kyanite eclogites of the Tauern window. Austria. J Geol 87:1-27.

Holland TJB (1980) The reaction albite $=$ jadeite + quartz determined experimentally in the range $600-1200{ }^{\circ} \mathrm{C}$. Am Mineral 65:125-134

Huang Y, Hawkesworth C, Smith I, van Calsteren P and Black P (2000) Geochemistry of late Cenozoic basaltic vocanism in Northland and Coromandel, New Zealand: implications for mantle enrichment processes. Chem Geol, 164:219-238.

Irvine TN and Baragar WRA (1971) A guide to the chemical classification of the common volcanic rocks. Can J Earth Sci, 8:523-548. 
Jagoutz E (1988) Nd and Sr systematics in an eclogite xenolith from Tanzania: evidence for frozen mineral equilibria in the continental lithosphere. Geochim Cosmochim Acta, 52:1285-1293.

Jahn BM (1998) Geochemical and isotope characteristics of UHP eclogites and ultramafic rocks of the Dabie Orogen: Implications for continental subduction and collisional tectonics. In: When continents collide: Geodynamics and geochemistry of ultrahighpressure rocks (eds Hacker BR and Liou JG), pp 203-239, Kluwer Academic Publishers.

Jahn BM, Cornichert J, Cong BL and Yui TF (1996) Ultrahigh-? Nd eclogites from an ultrahigh-pressure metamorphic terrane of China. Chem Geol, 127: 61-79.

Jahn BM, Potel S, Villa I, Whitehouse and Andriessen P, (1999a) Age and isotopic constraints to the architecture of the Dabie UHP metamorphic terrane, China. J Conf Abst (EUG10), 4(1):90.

Jahn BM, Wu F, Lo CH and Tsai CH (1999b) Crust-mantle interaction induced by deep subduction of the continental crust: geochemical and SrNd isotopic evidence from post-collisional mafic-ultramafic intrusions of the northern Dabie complex, central China. Chem Geol, 157:119-146.

Kalsbeek F (1992) Large-scale albitization of siltstones on Qeqertakavsak island, northeast Disko Bugt, West Greenland. Chem Geol, 95:213-233.

Kamineni DC, Bonardi M and Rao AT (1982) Halogen-bearing minerals from Airport Hill, Visakhapatnam, India. Am Mineral, 67:1001-1004.

Kennedy CS, Kennedy GC (1976) The equilibrium boundary between graphite and diamond. Jour Geophys Res 81:2467-2470.

Kerkhof van den AM (1988) The system $\mathrm{CO}_{2}-\mathrm{CH}_{4}-\mathrm{N}_{2}$ in fluid inclusions: theoretical modelling and geological applications. Free university Press, Amsterdam.

Klemd R (1991) Fluid inclusions in eclogite-facies metasediments from the Münchberg Gneiss Complex. NE- Bavaria (abstract). Plinius, 5:121-122.

Klemd R and Bröcker M, 1999. Fluid influence on mineral reactions in ultrahigh-pressure granulites: a case study in the Snieznik Mts. (West Sudetes, Poland). Contrib Mineral Petrol, 136, 358-373.

Klemd R, Kerkhof van den, $\mathrm{AM}$ and Horn EE (1993) High-density $\mathrm{CO}_{2}-\mathrm{N}_{2}$ inclusions in eclogite-facies metasediments of the Muenchberg gneiss complex, SE Germany. Contrib Mineral Petrol, 111:409-419. 
Kohn MJ and Valley JW (1998) Effects of cation substitutions in garnet and pyroxene on equilibrium oxygen isotope fractionations. J Metamorphic Geol, 16:625-639.

Kohn MJ and Spear FS (1990) Two new barometer for garnet amphibolites with applications to southeastern Vermont. Amer Mineral 75:89-96.

Krogh EJ (1988) The garnet-clinopyroxene Fe-Mg geothermometer - a reinterpretation of existing experimental data. Contrib Mineral Petrol 99:44-48.

Kullerud K (1995) Chlorine, titanium and barium-rich biotites: factors controlling biotite composition and the implications for garnet-biotite geothermometry. Contrib Mineral Petrol, 120:42-59.

Kullerud K (1996) Chlorine-rich amphiboles: Interplay between amphibole composition and an evolving fluid. Eur J Mineral, 8:355-370.

Kullerud K and Erambert M (1998) Cl-scapolite, Clamphibole, and plagioclase equilibria in ductile shear zones at Nusfjord, Lofoten, Norway: Implications for fluid compositional evolution during fluid-mineral interaction in the deep crust.

Kyser TK, O’Neil JR and Carmichael ISE (1981) Oxygen isotope thermometry of basic lavas and mantle nodules. Contrib Mineral Petrol 77:11-23.

Lamb WM, Valley JW and Brown PE (1987) Post-metamorphic $\mathrm{CO}_{2}$-rich fluid inclusions in granulites. Contrib Mineral Petrol, 96:485-495.

Lang HM (1996) Pressure-temperature-reaction history of metapelitic rocks from the Maryland Piedmont on the basis of correlated garnet zoning and plagioclase-inclusion composition. Am Mineral, 81:1460-1475.

Le Maitre RW, Bateman P, Dudek A, Keller J, Lameyer Le Bas MJSabine PA, Schmid R, Sorensen H., Streckeisen A, Woolley AR and Zanettin B (1989) A classification of igneous rocks and glossary of terms. Blackwell, Oxford.

Leake BE, Wolley AR, Arps CES, Birch WD, Gilbert MC, Grice JD, Hawthorne F, Kato A, Kisch HJ, Krivovichev VG, Linthout K, Laird J, Mandarino JA, Maresch WV, Nickel EH, Rock NMS, Schumacher JC, Smith DC, Stephenson NCN, Ungaretti L, Whittaker EJW and Guo Y (1997) Nomenclature of amphiboles: Report from the Subcommittee on Amphiboles of the International Mineralogical Association, Commission on New Minerals and Mineral Names. Am Mineral, 82:1019-1037.

Lee HY and Ganguly J (1988) Equilibrium compositions of coexisting garnet and orthopyroxene: experimental determinations in the system FeO-MgO-Al2O3-SiO2, and applications. J Petrol, 29:93-113. 
Leger A, Rebbert C and Webster J (1996) Cl-rich biotite and amphibole from Black Rock forest, Cornwall, New York. Am Mineral, 81:495-504.

Li SG, Chen YZ, Jagoutz E, Zhang ZQ, Chen W and Lo CH (1998) Geochemical and geochoronolgical constraints on the tectonic outline of the Dabie Mountains, central China: A continent-microcontinent-continent collision model. Continental Dynamics, 3:14-31.

Li SG, Hart SR, Zheng G and Guo A (1989). Timing of collision between the north and south China blocks - the Sm-Nd isotopic age evidence. Science in China (B), 32:1391-1400.

Li SG, Jagoutz E, Chen YZ and Li QL (2000) Sm-Nd and Rb-Sr isotopic chronology and cooling history of ultrahigh-pressure metamorphic rocks and their country rocks at Shuanghe in the Dabie Mountains, Central China. Geochim Cosmochim Acta, 64, 1077-1093.

Li SG, Liu DL, Chen YZ and Ge NJ (1992) The Sm-Nd isotopic age of coesite-bearing eclogite from the southern Dabie Mountains. Chinese Sci Bull, 37:1638-1641.

Li SG, Xiao YL, Liu DL, Chen YZ, Ge NG, Zhang ZQ, Sun SS, Cong BL, Zhang RG, Hart SR, Wang SS (1993) Collision of the North China and Yangtse Blocks and formation of coesite-bearing eclogites: Timing and processes. Chem Geol 109:89-111.

Lin JL, Fuller M and Zhang WY (1985) Preliminary Phanerozoic polar wander paths for the North and South China Blocks. Nature (London), 313:444-449.

Liou JG and Zhang RY (1995). Significance of ultrahigh-P talc-bearing eclogite assemblages. Mineral Mag 59:93-102.

Liou, J. G., Wang, Q., Zhai, M., Zhang, R. Y. \& Cong, B. L., 1995. Ultrahigh-P metamorphic rocks and their associated lithologies from the Dabie Mountains, central China: A field trip guide to the 3rd international eclogite field symposium. Chinese Science Bulettin, 40, 1-41.

Liou JG, Zhang RY, Ernst WG (1994) An introduction to ultrahigh-pressure metamorphism. Island Arc 3:1-24

Liou JG, Zhang RY and John BM (1997) Petrology, geochemistry and isotope data on a ultrahigh-pressure jadeite quartzite from Shuanghe, Dabie Mountains, East-central China. Lithos, 41:59-78.

Liou JG, Zhang RY, Wang XM, Eide EA, Ernst WG and Maruyama S (1996). Metamorphism and tectonics of high-pressure and ultrahigh-pressure belts in the Dabie-Sulu region, China. In: Yin A, Harrison TM (eds), The tectonic evolution of Asia. Cambridge Univ Press, UK, pp 300-344. 
Liu RX, Fan QC, Li H, Zhang Q, Zhao DS and Ma BL (1995), The natur of potolith of Bixiling garnet peridotite-eclogite massif in Dabie Mountains and the implication for its isotopic geochronology. Acta Petrol Sin, 11:243-256 (in Chinese).

Markl G and Bucher K (1998) Composition of fluids in the lower crust inferred from metamorphic salt in lower crustal rocks. Nature, 391:781-783.

Markl G, Ferry J and Bucher K (1998) Formation of saline brines and salt in lower crust by hydration reactions and partially retrogressed granulites from the Lofoten Islands, Norway. Am J Sci, 298:705-757.

Markl G, Musashi M and Bucher K (1997) Chlorine stable isotope composition of granulites from Lofoten, Norway: Implications for the $\mathrm{Cl}$ isotope composition and for the source of $\mathrm{Cl}$ enrichment in the lower crust. Earth Planet Sci Lett, 150:95-102.

Markl G and Piazolo S (1998) Halogen-bearing minerals in syenites and high-grade marbles of Donning Maud Land, Antarctica: Monitors of fluid compositional changes during late magmatic fluid-rock interaction processes. Contrib Mineral Petrol, 132:246-268.

Maruyama S, Liou JG and Zhang R (1994) Tectonic evolution of the ultrahigh-pressure (UHP) and high-pressure (HP) metamorphic belts from central China. The Island Arc, 3:112-121.

Matthews A (1994) Oxygen isotope geothermometers for metamorphic rocks. J Metamorphic Geol, 12:211-219.

Mattey D, Lowry D and Macpherson CG (1994) Oxygen isotope composition of mantle peridotite. Earth Planet Sci Lett, 128:231-241.

McCulloch MT and Gamble JA (1991) Geochemical and geodynamical constraints on subduction zone magmatism. Earth Planet Sci lett, 102:358-374.

Merrit DA, Hayes JM (1994) Factors controlling precision and accuracy in isotope-ratiomonitoring mass spectrometry. Anal Chem 66:2336-2347.

Mezger K, Essene EJ and Holliday AN (1992) Closure temperature of the Sm-Nd system in metamorphic garnets. Earth Planet Sci Lett, 113:397-409.

Morimoto N, Fabries J, Ferguson AK, Ginzburg IV, Ross M, Seifert FA and Zussman J (1988) Nomenclature of pyroxenes. Am Mineral, 73:1123-1133.

Morrison JM (1991) Compositional constraints on the incorporation of $\mathrm{Cl}$ into amphiboles. Am Mineral, 76:1920-1930.

Murk BW, Burruss RC and Hollister LS (1978) Phase equilibria in fluid inclusions in ultramafic xenoliths. Am Mineral, 63:40-46. 
Nakamura D and Hirajima T (2000) Granulite-facies overprinting of ultrahigh-pressure metamorphic rocks, northern SuLu region, eastern China. J Petrol, 41:563-582.

Newton RC (1986) Metamorphic temperature and pressure of group B and C eclogites. Geol Soc Am Mem, 164:17-30.

Norris TL and Schaeffer OA (1982) Total nitrogen content of deep sea basalts. Geochim Cosmoschim Acta, 46:371-379.

Oberti R, Ungaretti L, Cannillo E and Hawthore FC (1993) The machanism of Cl incorporated in amphibole. Am Mineral, 78:746-752.

Okamoto K, Maruyama S (1998) Multi-anvil re-equilibration experiments of a Dabie Shan ultrahigh-pressure eclogite within the diamond-stability fields. The Island Arc 7:52-69.

Okay AI (1993) Petrology of a diamond and coesite-bearing metamorphic terrain: Dabie Shan, China. Eur J Mineral 5:659-675.

Okay AI (1994) Sapphirine and Ticlinohumite in ultra-high-pressure garnet-pyroxenite and eclogite from Dabie Shan, China. Contrib Mineral Petrol 116:145-155.

Okay AI and Sengör AMC (1993) Tectonic of an ultrahigh-pressure metamorphic tettane: The Dabie Shan/Tongbai Shan orogen, China. Tectonics, 12:1329-1334.

Okay AI, Xu ST, Sengor AMC (1989) Coesite from the Dabie Shan eclogites central China. Eur J Mineral 1:595-598.

Olafsson M and Eggler DH (1983) Phase relations of amphibole, amphibole-carbonate, and phlogopite-carbonate peridotite: petrologic constraints on the asthenosphere. Earth Planet Sci Lett 64:305-315.

O'Neil JR (1986), Appendix: Terminology and standards. In: Valley JW, Taylor HP, O’Neil JR (eds), Stable isotope in high temperature geological processes. Mineral Soc Am Rev Mineral 16:561-570.

Pasteris JD (1987) Fluid inclusions in mantle xenoliths. In: Mantle Xenoliths (ed. Nixon, P. H.), Wiley, Chichester, pp. 691-707.

Pearce JA (1982) Trace element characteristics of lavas from destructive plate boundaries. In: Thorpe RS (ed), Andesites. Wiley, Chichester, pp 525-548.

Perchuk LL (1969) The effect of temperature and pressure on the equilibrium of natural ironmagnesium minerals. Inter Geol Rev 11:875-901.

Philiport PP (1993), Fluid-melt-rock interaction in mafic eclogites and coesite-bearing metasediments: Constrains on volatile recycling during subduction. Chem Geol 108:93112. 
Philiport P, Chevallier P and Chopin C (1995) Fluid composition and evolution in coesitebearing rocks (Dora-Maira massif, Westera Alps): implications for element recycling during subduction. Contrib Mineral Petrol 121:29-44.

Philippot P and Selverstone J (1991) Trace-element rich brines in eclogitic veins; implications for fluid composition and transport during subduction. Contrib Mineral Petrol 106:417-430.

Poli S and Schmidt MW (1995) $\mathrm{H}_{2} \mathrm{O}$ transport and release in subduction zones: Experimental constrains on basaltic and andesitic systems. J Geophys Res, 100:22299-22314.

Powell R (1985) Regression diagnostic and robust regression in geothermometer/ geobarometer calibration: The garnet-clinopyroxene geothermometer revisited. J Metamorph Geol, 3:231-243.

Raase P (1974) Al and Ti contentsof hornblende, indicators of pressure and temperature of regional metamorphism. Contrib Mineral Petrol 45:231-236.

Råheim A and Green DH (1975) P-T paths of natural eclogites during metamorphism - a record of subduction. Lithos 8:317-328.

Roedder, E., 1965. Liquid $\mathrm{CO}_{2}$ inclusions in olivine-bearing nodules and phenocrysts from basalts. Am Minerat, 50:1746-1782.

Roedder, E., 1984. Fluid Inclusions. Reviews Mineral, 12:503-532.

Rowley D, Xue F, Tucker R, Peng ZX, Baker J and Davis A (1997) Ages of ultrahigh pressure metamorphism and protolith orthogneisses from the eastern Dabie Shan: $\mathrm{U} / \mathrm{Pb}$ zircon geochronology. Earth Planet Sci Lett 151:191-203.

Rumble D and Yui TF (1998) The Qinglongshan oxygen and hydrogen isotope anomaly near Donghai in Jiangsu Province, China. Geochim Cosmochim Acta 62:3307-3321.

Santosh M (1991) Role of $\mathrm{CO}_{2}$ in granulite petrogenesis: Evidence from fluid inclusions. J Geosci Osaka City Univ, 34:1-53.

Schertl HP and Okay AI (1994) Coesite inclusion in dolomite of Dabie Shan, China: Petrological and rheological significance. Eur J Mineral 6:995-1000.

Schmidt C, Chou IM, Bodnar RJ, Bassett W (1998) Microthermometric analysis of synthetic fluid inclusions in the hydrothermal diamond-anvil cell. Amer Minerol 83:995-1007

Seifert KE, Chang CW and Brunotte DA (1997) Evidence from Ocean Drilling Program Leg 149 mafic igneous rocks for oceanic crust in the Iberia Abyssal Plain ocean-continental transition zone. J Geophysical Research, 102(10):7915-7928. 
Selverstone J, Franz G, Thomas S (1992) Fluid heterogeneities in 2 G Pa eclogites: implications for element recycling during subduction. Contrib Mineral Petrol 112:341357.

Selverstone J, Spear FS, Franz G and Morteani G (1984) High-pressure metamorphism in the SW Tauern Window, Austria; P-T paths from hornblende-kyanite-staurolite schists. J Petrol, 25:501-531.

Sharp ZD (1990). A laser-based microanalytical method for the in situ determination of oxygen isotope ratios of silicates and oxides. Geochim Cosmochim Acta, 54:13531357.

Sharp ZD, Essene EJ, Hunzicker JC (1993) Stable isotope geochemistry and phase equilibria of coesite-bearing whiteschists, Dora-Maira Massif, western Alps. Contrib Mineral Petrol 114:1-12.

Sheppard SMF (1986) Characterization and isotopic variations in natural waters. In: Stable isotopes in high temperature geological processes. Rev Mineral, 16:165-183.

Shervais JW (1982) Ti-V plots and the petrogenesis of modern and ophiolitic lavas. Earth Planet Sci Lett, 59:101-118.

Simon K, Wiechert U, Hoefs J and Grote B (1997) Microanalysis of minerals by laser ablation ICPMS and SIRMS. Fresenius J Annu Chem, 359:458-461.

Smith DC (1984) Coesite in clinopyroxene in the Caledonides and its implications for geodynamics. Nature, 310:641-644.

Sobolev NV and Shatsky VS (1990) Diamond inclusions in garnets from metamorphic rocks. Nature 343:742-746.

Sobolev NV, Shatsky VS, Vavilov MA and Goryainov SV (1994) Zircon from ultrahighpressure metamorphic rocks of folded regions as an unique container of inclusion of diamond, coesite and coexisting minerals. Doklady Akademii Nauk, 334:488-492.

Song Y and Frey FA (1989) Geochemistry of peridotite xenoliths in basalt from Hannuoba, East China: implications for subcontinental mantle heterogeneity. Geochim Cosmochim Acta, 53:97-113.

Spear FS (1989) Relative thermobarometry and metamorphic P-T paths. In: Evolution of metamorphic belts. Daly JS, Cliff RA and Yardky BWD (eds), Geological Society, Landon, pp. 63-81.

Spear FS (1993) Metamorphic P-T paths and tectonic evolution: Examples. In: Metamorphic Phase Equilibria and Pressure-Temperature-Time Paths. Spear FS (ed), , Mineral Soc Am, Washington DC, pp. 737-766. 
Sun SS (1982) Chemical composition and origin of the earth's primitive mantle. Geochim Cosmochim Acta, 46:179-192.

Sun SS and McDonough WF (1989) Chemical and isotopic systematics of oceanic basalts: implications for mantle composition and processes. In: Magmatism in ocean basins. Saunders AD and Norry MJ (eds), Geol Soc London, Spec Pub 42, pp313-345.

Suwa K, Enami M and Horiuchi T (1987) Chlorine-rich potassium hastingsite from west island, Lützow -Holm Bay, East Antarctica. Mineral Magz, 51:709-704.

Taylor SR (1977) Island arc models and the composition of the continental crust. AGU Ewing Series, I-325.

Taylor SR and McLennan SM (1985) The continental crust: its composition and evolution. Blackwell, Oxford.

Taylor BE and O'Neil JR (1977) Stable isotope sudies of metasomatic skarn and associated metamorphic and igneous rocks, Osgood Mountains, Neveda. Contrin Mineral Petrol, 63:1-49.

Thompson AB (1992) Water in the Earth's upper mantle. Nature 358:295-302.

Touret JLR (1981) Fluid inclusions in high grade metamorphic rocks. In: Fluid inclusions: application to petrology. Hollister L and Crawford M (eds). Mineral Associ Canada Short Course Handbook 6, pp. 182-208.

Touret JLR (1989) Fluid control in the lower crust. In: Gesteinsfluide. Veroeff Niedersächs Akad Geowiss, 1:57-68.

Touret JLR (1992) Fluid inclusions in subducted rocks. Proc Kon Ned Akad Wetensch, 95(3):385-403.

Touret JLR and Huizenga JM (1999) Precambrian intraplate magmatism: high temperature, low pressure crustal granulites. J African Earth Sci, 28(2):367-382.

Tsai CH and Liou JG (2000). Eclogite-facies relics and inferred ultrahigh-pressure metamorphism in the North Dabie complex, central -eastern China. Am Mineral, 85, 18.

Valley JW, Bohlen SR, Essene EJ and Lamb W (1990) Metamorphism in the Adirondacks: II. The role of fluids. J Petrol, 31:555-596.

Vanko DA (1986)High-chlorine amphiboles from oceanic rocks: Product of highly-saline hydrothermal fluids? Am Mineral, 71:51-59.

Vry JK and Brown PE (1991) Texturally-early fluid inclusions in garnets: evidence of the prograde metamorphic path? Contrib Mineral Petrol, 108:271-282. 
Volfinger M, Robert JL, Vielzeuf D and Neiva AMR (1985) Structure control of the chlorine content of OH-bearing silicates (micas and amphiboles). Geochim Cosmoschim Acta, 49:37-48.

Wang QC, Ishiwatari A, Zhao ZY, Hirajima T, Enami M, Zhai MG, Li JL and Cong BL (1993) Coesite-bearing granulite retrograded from eclogite in Weihai, eastern China. Eur J Mineral, 5:141-152.

Wang QC, Zhai MG, Cong BL (1996) Regional geology. In : Cong BL (ed), UltrahigPressure Metamorphic Rocks in the Dabie-Sulu Region of China. Science Press, Beijing and Kluwer Acad Publ, Dordrecht, pp 8-26.

Wang X (1990). Petrology of coesite-bearing eclogites and ultramafic rocks from ultrahighpressure metamorphic terrain of the Dabie Mountains and implications to regional tectonics in central China. PhD Thesis, Stanford University, Stanford.

Wang X, Liou JG, Mao HK (1989) Coesite-bearing eclogites from the Dabie Mountains, central China. Geology 17:1085-1088.

Wang X and Liou JG (1991) Regional ultrahigh-pressure coesite-bearing eclogitic terrain in central China: Evidence from country rocks, gneiss, marble and metapelite. Geology, 19:933-936.

Wang X, Liou JG and Maruyama S (1992) Coesite-bearing eclogites from the Dabie Mountains, Central China: Petrology and P-T path. J Geol, 100:231-250.

Wang X, Zhang RY and Liou JG (1995) Ultrahigh-pressure metamorphic terrane in eastern central China. In: Ultrahigh-Pressure Metamorphism. Coleman RG and Wang X (eds), Cambridge University Press, Cambridge, pp. 356-390.

Wang W and Takahashi E (1999) Subsolidus and melting experiments of a K-rich basaltic composition to $27 \mathrm{GPa}$ : Implication for the behaviour of potassium in the mantle. Am Mineral 84: 357-361.

Watson EB, Brenan JM and Baker DR (1990) Distribution of fluids in the continental mantle. In: Continental Mantle, Anderson DL (ed) pp 111-125.

Weaver B and Tarney J (1984) Empirical approach to estimating the composition of the continental crust. Nature, 310:575-577.

Wiechert U, Fiebig J, Przybilla R, Xiao Y, Hoefs J (2001) Excimer Laser Ablation IsotopeRatio-Monitoring Mass Spectrometry for in-situ $\delta^{18} \mathrm{O}$ Analysis. Chem Geol (in press).

Wiechert U and Hoefs $\mathbf{J}$ (1995) An excimer laser-based micro analytical preparation technique for in situ oxygen isotope analysis of silicate and oxide minerals. Geochim Cosmochim Acta, 59:4093-4101. 
Wickham SM and Taylor Jr HP (1987) Stable isotope constraints on the origin and depth of penetration of hydrothermal fluids associated with Hercynian regional metamorphism and crustal anatexis in the Pyrenees. Contrib Mineral Petrol 95:255-268.

Wlotzka F (1961) Untersuchungen zur Geochemie des Stickstoffs. Geochim Cosmochim Acta, 24, 106-154.

Wood BJ and Banno S (1973) Garnet-Orthopyroxene and Orthopyroxene-Clinopyroxene Relationships in Simple and Complex Systems. Contrib Mineral Petrol, 42:109-124.

Xiao YL (1991) P-T-t paths of eclogites from Dabie Shan, eastern China. Master's thsis, University of Science and Technology of China, Hefei (unpublished, in Chinese).

Xiao YL, Fu B, Li SG, Zheng YF (1997) Metamorphic P-T and oxygen isotope studies of coesite-bearing eclogite from the Dabie Mountains. Acta Geoscientia Sinica 18:318323 (in Chinese with English abstract)

Xiao YL, Hoefs J, van den Kerkhof AM., Fiebig J and Zheng YF (2000) Fluid history of UHP metamorphism in the Dabie Shan, China: a fluid inclusion and oxygen isotope study on the coesite-bearing eclogite from Bixiling. Contrib Mineral Petrol, 139:1-16.

Xiao YL, Hoefs J, van den Kerkhof AM and Li SG (2001) Geochemical constraints of the eclogite and granulite facies metamorphism as recognized in the Raobazhai complex from North Dabie Shan, China. J Metamorph Geol, 19:1-17.

Xiao YL and Li SG (1993) P-T-t path and its tectonic implication for eclogite from the Shima, Dabie Mountains. Geotectonia et Metallogenia, 17, 239-250 (in Chinese with English abstract).

Xiao YL, Li SG, Jagoutz E and Cheng W (1995) P-T-t path for coesite-bearing peridotite eclogite association in the Bixiling, Dabie Mountains. Chinese Sci Bull 40:156-158.

Xiao YL, Zheng YF and Fu B and Ge NJ (1998), Oxygen isotope geochemistry of granulite inclusions in the Dabie Mountains. Geol Rev, 2:181-187 (in Chinese with English abstracter).

Xie Z, Chen JF, Zhou T and Zhang X (1996) Nd isotopic compositions of metamorphic and granitic rocks from Dabie orogen and their geological significance. Acta Petrol Sinica, 12:401-408 (in Chinese with English abstracter).

$\mathrm{Xu}$ G (1989) Characteristics and geotectonic environment of the ophilite in the Dabie Mountains, Anhui Province. J Changchun Univ, 19:165-174.

Xu ST, Liu YC, Jiang LL, Su W and Ji SY (1994) Tectonic Regime and Evolution of Dabie Mountains. Science Press, Beijing (in Chinese). 
Xu ST, Okay AI, Ji S (1992) Diamond from the Dabie Shan metamorphic rocks and its implication for tectonic setting. Science, 256:80-82.

Xue F, Rowley DB and Baker J (1996) Refolded syn-ultrahigh-pressure thrust sheets in the South Dabie complex, China: Field evidence and tectonic implications. Geology, 24:455-458.

Xue F, Rowley DB, Tucker RD and Peng XZ (1997) UPb zircon ages of granitoid rocks in the North Dabie Complex, eastern Dabie Shan, China. J Geol, 105:744-753.

Yang XY (1983). A cold ultramafic intrusive body in Dabieshan area, Anhui Province - A reconsideration about the Raobazhai intrusive body in the Huoshan County. Bulletin of the Nanjing Institute of Geology and Mineral Resources, Chinese Science of Geosciences, 4:81(in Chinese).

Yang Z, Courtillot V, Besse J, Ma X, Xing L, Xu S and Zhang J (1992) Jurassic paleomagnetic constraints on the collision of the North and South Blocks. Geophy Res Lett, 19:577-580.

Yang Z, Ma X, Besse J, Courtillot V, Xing L, Zhang J and Xu S (1991), Paleomagnetic results from the Triassic sections in the Ordos basin, North China. Earth Planet Sci Lett, 104:258-277.

Yao YP, Ye K, Liu JB, Cong BL and Wang QC (2000) A transitional eclogite- to highpressure garnulite-facies overprint on coesite-eclogite at Taohang in the Sulu ultrahighpressure terrine, eastern China. Lithos, 52:109-120.

Ye K, Cong B and Ye D (2000) The possible subduction of continental material to depths greater than $200 \mathrm{~km}$. Nature, 407(12):734-736.

You ZD, Chen NS, Chalokwu CI (1995). The metamorphism of deeper crust in the Dabie Mountains: as evidenced by the study of granulites near Huilanshan, Luotian. Acta Petrologica Sinica, 11:137-147 (in Chinese).

You ZD, Han YJ, Yang WR, Zhang ZM, Wie B, Liu R (1996) The high-pressure and ultrahigh-pressure metamorphic belt in the East Qinling and Dabie Mountains, China. China University of Geosciences Press, Wuhan, pp 82-95.

Yui TF, Rumble D and Lo CH (1995) Unusually low $\delta^{18} \mathrm{O}$ ultra-high-pressure metamorphic rocks from the Sulu Terrain, eartern China. Geochim Cosmochim Acta 59:2859-2864.

Yui TF, Rumble D, Chen CH and Lo CH (1997) Stable isotope characteristics of eclogites from the ultra-high-pressure metamorphic terrain, east-central China. Chem Geol 137:135-147. 
Zhai MG, Cong BL, Zhang Q, Wang QC (1994) The northern Dabieshan terrain: a possible Andean-type arc. Inter Geol Rev, 36:867-883.

Zhang LG (1985) Applications of Stable Isotopes to Geological Sciences. Press of Shanxi Science and Techlonogy, Xian, pp267.

Zhang Q, Ma BL, Liu RX, Zhao DS, Fan QC, Li Q and Li XY (1995). A remnant of continental lithospheric mantle above subduction zone: geochemical constraints on ultramafic rock from Raobazhai area, Anhui Province. Science in China (Series B), 38:1522-1529.

Zhang RY and Cong B (1983), Mineral Geothermometry and mineral Geobarometry. Geological Press, Beijing, 280 pp (in Chinese).

Zhang RY and Liou JG (1994) Significance of magnesite paragenesis in ultrahigh-P metamorphic rocks. Am Minerl 79:397-400

Zhang RY and Liou JG (1998) Ultrahigh-pressure metamorphism of the Sulu terrain, eastern China: A prospective view. Continental Dynamics, 3, 32-53.

Zhang RY, Liou JG and Tsai CH (1996) Petrogenesis of a high-temperature metamorphic terrane: a new tectonic interpretation for the north Dabieshan, central China. J Metamorphic Geol, 3:231-243.

Zhang RY, Liou JG, Cong BL (1995) Talc-, magnesite- and Ti-clinohumite-bearing UHP meta-mafic and ultramafic complex in the Dabie Mountains, China. J Petrol 36:10111037.

Zhang RY, Rumble D, Liou JG and Wang QC (1998) Low -d18O, ultrahigh-P garnet-bearing mafic and ultramafic rocks from Dabie Shan, China. Chem Geol, 150:161-170.

Zheng YF (1993a) Calculation of oxygen isotope fractionation in anhydrous silicate minerals. Geochim Cosmochim Acta 57:1079-1091.

Zheng YF (1993b) Calculation of oxygen isotope fractionation in hydroxyl-bearing silicates. Earth Planet Sci Lett 120:247-263.

Zheng YF, Fu B and Gong B (1996) Extreme ${ }^{18} \mathrm{O}$ depletion in eclogite from the SuLu terrain in East China. Eur J Mineral, 8:317-323.

Zheng YF, Fu B, Li YL, Xiao YL, Li S (1998) Oxygen and hydrogen isotope geochemistry of ultrahigh-pressure eclogites from the Dabie Mountains and the Sulu terrane. Earth and Planetary Sci Lett 155:113-129.

Zheng YF, Fu B, Xiao YL, Li YL, Gong B (1999) Hydrogen and oxygen isotope evidence for fluid-rock interactions in the stages of pre- and post-UHP metamorphism in the Dabie Mountains. Lithos 46:677-693. 
Zhu C and Sverjensky DA (1991) Partitioning of $\mathrm{F}, \mathrm{Cl}, \mathrm{OH}$ between minerals and 8 hyddrothermal fluids. Geochim Cosmochim Acta, 55:1837-1858.

Zhu C, Xu HF, Ilton ES, Veblen DR, Henry DJ, Tivey MK and Thompson G (1994) TEMAEM observations of Cl-rich amphibole and biotite and possible petrologic implications. Am Mineral, 79:909-920. 